\title{
THE WILD-FOWL
}

\author{
AND SEA-FOWL \\ of
}

GREAT BRITAIN

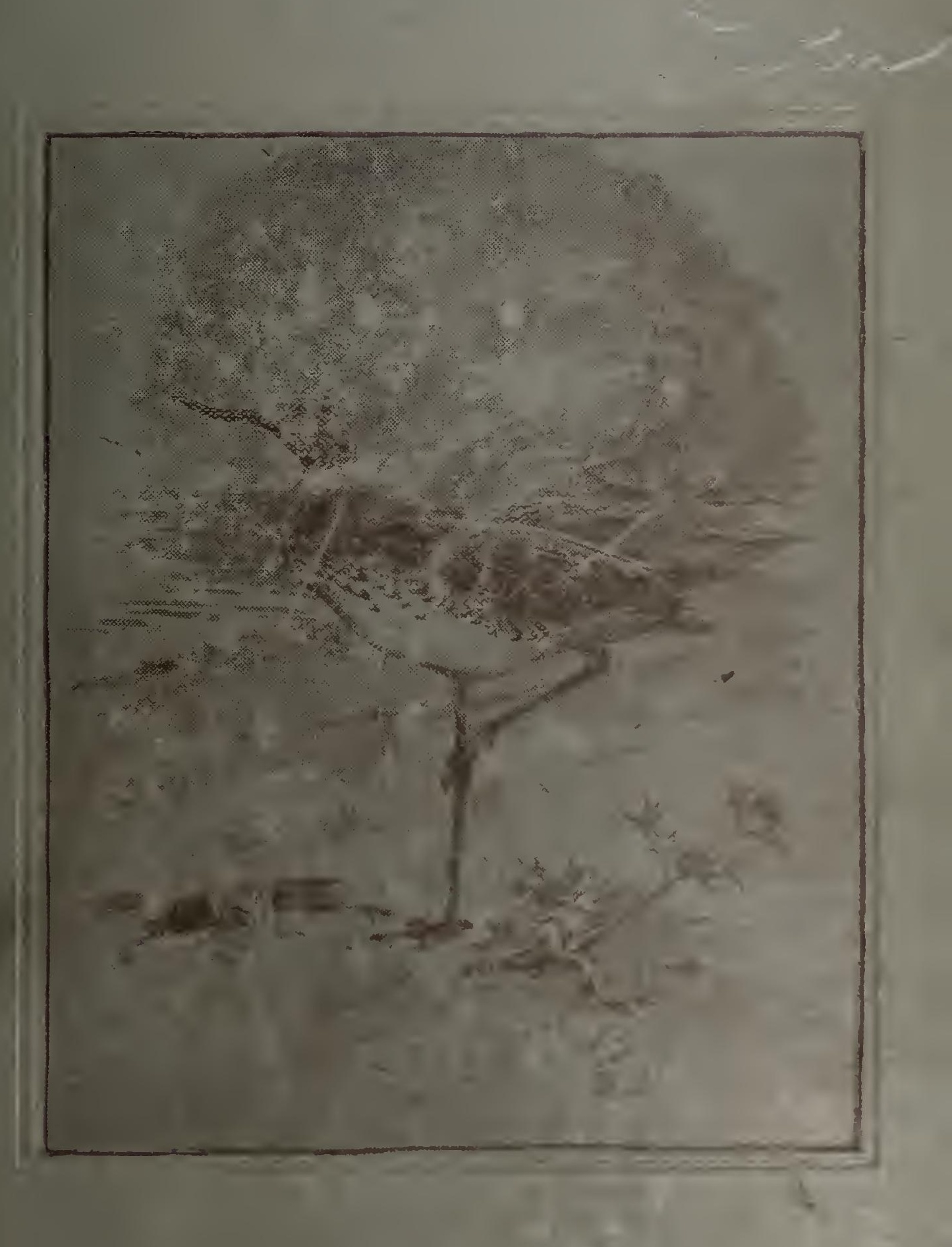






\title{
THE WILD-FOWL AND SEA-FOTIL oF
}

\author{
GREAT BRITAIN
}






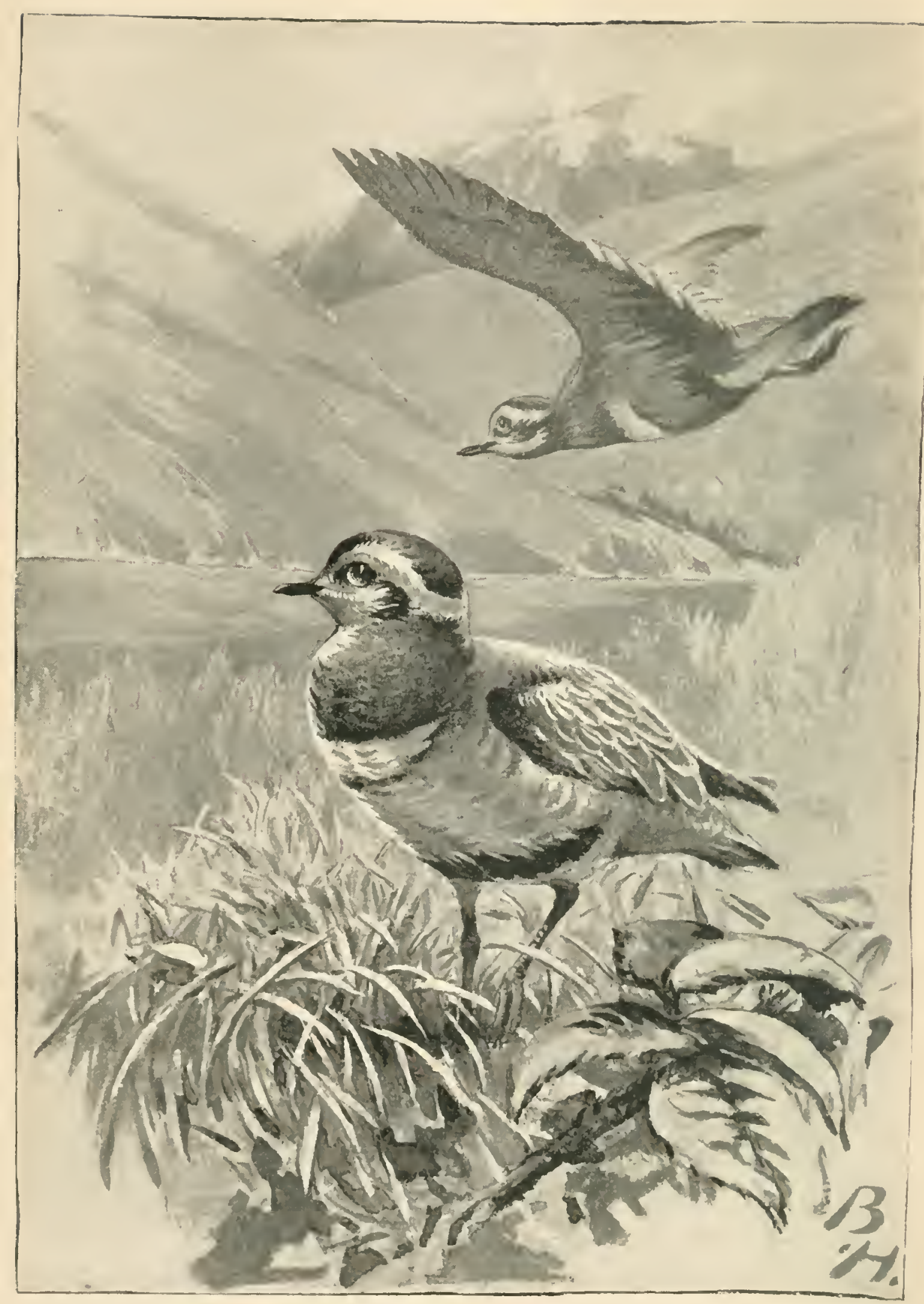

DOTTEREL. 
THE

\section{WILD-FOWL AND SEA-FOWL}

OF

\section{GREAT BRITAIN}

$\cdot \mathrm{BX}$

A SON OF THE MARSHES

AUTHOR OF "ON SURREY HLLLS," "WOODLAND, MOOR, AND STREAM"

EDITED BY J. A. OIVEN

WITH XLLUSTRATIONS RY BRYAN HOOK

LONDON: CHAPMAN AND HALL, LD.

$$
\text { I } 995
$$

[All rights rescied] 


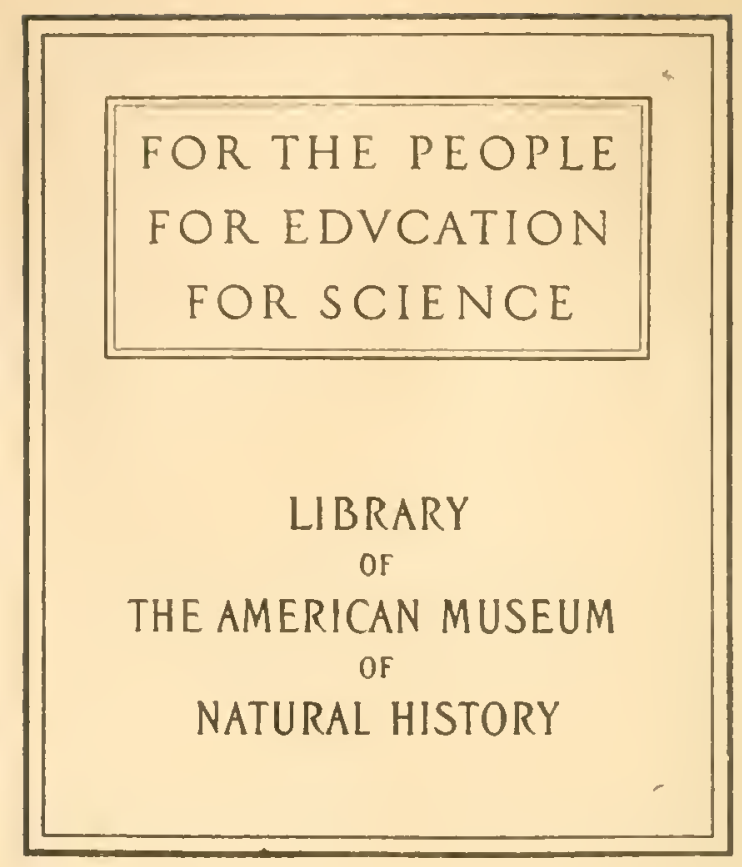

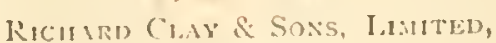

luninOR \& liUngay. 


\section{PREFACE}

Mr childhood and youth were spent on the foreshores and in the marsh-lands of North Kent, where I associated freely with the shore-shooters and the fishing-folk as one of themselves. At the same time some of the best standard works of that day were open to me through connections of my own.

The sketches of character given are from the life. There was a quaintness and an originality about our marsh-land folks that I have never met with elsewhere.

Although I no longer handle a gun - having exchanged it for a field-glass-I have never been out of touch with the old friends of my youth, and specimens of the birds have been sent to me fresh from the tide, and have lain before me as I wrote these chapters on wild-fowl and sea-fowl.

A Son of tile marsies. 



\section{CONTENTS}

CHAP.

1. THE GREAT AND LITTLE EUSTARDS _.. $\quad \ldots \quad$ I

11. THE STONE CURLEW OR THICK-KNEE $\ldots$... 9

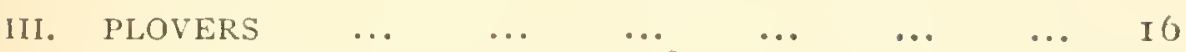

1V. THE RUFF AND THE REEVE $\quad \ldots . \quad \ldots . \quad \ldots \quad 3 S$

V. SANDPIPERS AND THE SANDERLING $\ldots . \quad \ldots \quad 43$

VI. GREAT CURLEIV AND WHIMBREL $\ldots \quad \ldots 6 \quad \ldots 6$

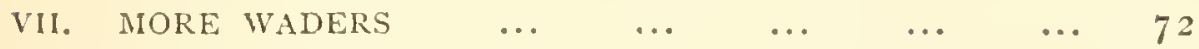

VII. WOODCOCK AND SNIPE $\quad \ldots \quad \ldots \quad \ldots \quad \ldots \quad \ldots$

1X. THE COMIION HERON $\quad \ldots \quad \ldots \ldots$ II

X. THE COMION AND THE LITTLE BITTERN ... ... I 23

XI. THE WHITE SPOONBILL $\quad \ldots \quad \ldots \ldots Z^{2}$

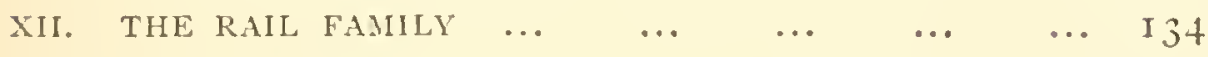

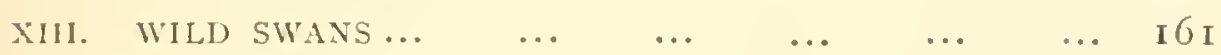

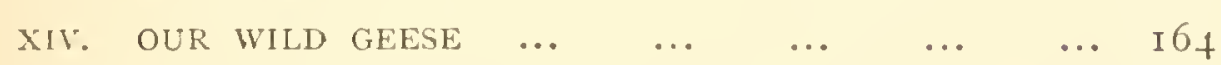

XiV. TIIE SHELD-DUCK $\quad \ldots \quad \ldots \quad \ldots \quad \ldots \quad \ldots \quad \ldots$

XVI. THE COMMON WILD DUCK $\ldots \quad \ldots \ldots \mathrm{I}_{3}$

XVII. THE TEAL AND G.IRG.INET ... ... ... ... $20 S$

XVII. THE PINTAIL DUCK AND TIE SHOVELLER $\ldots 20$

XIX. MORE OF THE WILD DUCK FAMHLY $\ldots 2 \ldots$

XX. THE GOOSANDER AND THE TIED SMEW $\ldots . \ldots \ldots 252$

XXI. THE WIGEON AND POCHARDS $\quad \ldots \quad \ldots \quad \ldots \quad \ldots 262$

XXI1. TILE GUILLEMOT, LITTLE AUK, RAZOR-BILL, AND I'UFFIN $\quad \ldots \quad \ldots \quad \ldots \quad \ldots \quad \ldots \quad \ldots \quad \ldots \quad \ldots S_{4}$

XXII. DIVERS $\triangle N D$ GRERES $\quad \ldots \quad \ldots . \quad \ldots \quad \ldots \quad \ldots 0$

XXIV. CORMORANTS AND GANNET $\quad \ldots . \quad \ldots . \quad \ldots \quad 303$

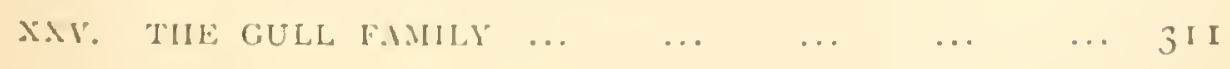

$\begin{array}{llllllll}\text { INDEX } & \ldots & \ldots & \ldots & \ldots & \ldots & \ldots & 325\end{array}$ 


\section{LIST OF ILLUSTRATIONS}

\begin{tabular}{|c|c|c|c|c|c|c|c|c|}
\hline DOTTEREL... & $\cdots$ & $\cdots$ & $\cdots$ & $\cdots$ & .. & \multicolumn{3}{|c|}{ Frontispiece } \\
\hline STONE CURLEW & $\ldots$ & $\cdots$ & .. & .. & .. & To & face. & p. $\mathbf{1} 4$ \\
\hline COMMON RINGED & DOTTEF & KEL & $\cdots$ & $\ldots$ & $\ldots$ & " & $"$ & 24 \\
\hline CURLEW ... & $\ldots$ & $\ldots$ & $\cdots$ & $\cdots$ & .. &, & ," & 65 \\
\hline GREENSHANK & $\cdots$ & $\cdots$ & $\cdots$ & $\cdots$ & .. &, & $"$ & 78 \\
\hline HERON AND FALC & CONS & .. & ... & $\cdots$ & $\ldots$ & $"$ & $"$ & 119 \\
\hline BERNACLE GEESE & $\cdots$ & $\ldots$ & $\cdots$ & $\cdots$ & $\cdots$ & ", & ", & 167 \\
\hline SHELD-DUCK & $\cdots$ & $\cdots$ & $\cdots$ & $\cdots$ & $\cdots$ & , & ", & .77 \\
\hline TEAL-A FAMILY & PARTY & $\cdots$ & $\cdots$ & $\cdots$ & $\cdots$ & , & " & 2 I I \\
\hline TUFTED DUCK & $\cdots$ & $\cdots$ & $\cdots$ & $\cdots$ & .. & $"$ & $"$ & 230 \\
\hline GREAT NORTHERN & N DIVER & & $\cdots$ & $\cdots$ & $\cdots$ & ", & $"$ & 290 \\
\hline GREAT BLACK-BAC & CKED GL & ULL & ... & ... & .. & , & , & 312 \\
\hline
\end{tabular}




\title{
THE WILD-FOWL AND SEA-FOIVL
}

\author{
OF

\section{GREAT BRITAIN}

\author{
CHAPTER I \\ TIE GREAT AND LITTLE BUSTARDS
}

This noble bird, which was once indigenous to the plains and wastes of this country, has been exterminated as a resident, and no consolation can be derived from this mournful fact in any shape or way. The feathered coursers of the Yorkshire wolds and the Wiltshire Downs are gone; the lands that they once frequented remain pretty much as they were, but the Bustards are gone, and taking into consideration the means and ways employed for their destruction, the fact can hardly be a matter of wonder.

I have some old records by me, relating to the middle and latter part of the seventecnth century and the carly part of the eightecnth. They tell of 
the game and wild-fowl, as well as fish, which were brought to the markets by those huge carricrs' wagons that moved all over England,-or those parts of it where there were roads fit for travelling over, not simply tracks, - - horsed with the finest draught animals that could be procured, bred expressly for their purpose, just as others were for the mail and ordinary coaches that have passed away within my own time.

I have seen deliveries of game and fowl made to the wagons and coaches in those old days. A horse or donkey would bring the consignment from some out-of-the-way place and wait by the side of the main road with it until the coach or wagon came along. No time or words were wasted; almost as quickly as I could write a few lines about it the coach or wagon was on its way again. Even in "those slow times," as one hears wise and experienced sages of the ripe age of twenty-five of the present day call them, they had a system, and a good honest one. If you expected a thing you generally got it, in good order, at the time you looked for it. The coaches and wagons were timed to arrive at certain places, setting aside accidents or snow-drifts, and as a rule they could be depended upon.

Thirty miles south from Dorking, and less from that westward, will place us in some of the old haunts of the Bustard, which are visited even at the present time by solitary members of the species. Their old coursing grounds are lonely and beautiful 
as of old. Plain country may look perfectly flat, but even the vast table-lands on the crests of the hills are not as they appear, though the rifts in them are not visible until you come on them as you travel over the short green turf, which is sheep-fed and rabbitnibbled until it looks almost like green pile velvet.

The traditions of the Bustard have not passed away. A lonely public-house on the Downs is still standing which has a Bustard painted on its signboard. There I have heard the old men mention what their fathers have heard and told them. Some had actually, so they said, seen small flocks of the Bustard when they were young. From what they let drop in the course of the conversation I should certainly say that the fathers of those old men had not only seen such things, but had themselves assisted in their capture. Running them down in moulting time was incidentally mentioned. Now this is quite practical; there is no exaggeration here, for the Bustard drops nearly all its flight-feathers at one time, and then so far as flying goes the great bird is helpless, having only its swift legs and feet to rely on, and its self-protective instincts. The feathers dropped by the birds as they wandered over their wide, bare, grassy feeding-grounds would tell the tale to those keen-eyed rangers of the plain; just as plainly as do our clomestic geese when they drop their feathers in the moulting time on the commons they graze over.

First-class greyhounds and lurchers have ever been in favour in this country; what more easy, 
when the Bustards frequented here, than to run them down? This was just what was done. No one visited the Bustards' haunts at that time except the shepherds, who lived a half-nomad life, one that was almost as wild as the birds they saw around them, that they did their best to capture at times, and those whose business compelled them to pass along the lonely roads that ran through and over the plains and heaths they frequented.

At that time you would have been quite as likely to fall in with a highwayman as you would with a Bustard. The mail-coaches of course carried arms, so did some of their passengers, and those, too, who travelled swiftly with a carriage and four horses, on business of urgent import. These haunts had a bad reputation, and if all I have been able to gather is true, they deserved it. Some rather unpleasant transmitted traits yet show themselves, which would fully bear out what I have hinted at.

There was a market at that time for Bustards, and a supply. Law and order, as we know them now, were unknown, or if known, not regarded. The forefathers of the people now scattered about there would not be denied, if they thought they wanted anything; the thought was at once acted on. Some places I know well where I would not stop longer than I was obliged to, even now. Yet if you wish to see real life you must go to wild places for it.

But you must go out of the United Kingdom if you want to see the Bustard at home now, to the 
wilder parts of Spain. We gather this from the information gained in their haunts by two wellknown authors on ornithological matters.

Our South Downs were much favoured by the Bustards. You may yet meet some ancient shepherd there who will tell you he has seen one or two stray visitants, or what is far more possible, he will tell you what his father has told him years ago. If they find you interested in their tales of the hiils, past and present, you may safely rely on the accuracy of the information these old men give you. They do not get a chat with a stranger very often up there.

The Bustard feeds chiefly on grain and green food of various kinds, trefoils, charlock, rape, etc. The advance of cultivation has had something to do with the extinction of the Bustard, but not everything. Bustards have been killed off, too, in ways I need not mention; for those who killed them have left records behind them on that subject. They would, however, be here now, if those stray birds that tried to make settlements from time to time had been left unmolested. So-called scientists and egg-collectors have much to answer for.

The Little Bustard can only be considered as a rare straggler; those eggs of the bird which I have seen were procured on the Continent. As the bird has not nested in this country, we need not describe them. In its haunts it is consiclered to be one of the most wary birds that the shooter goes in search of. It is far more cautious than its large relative, 
and its flight quicker. When the cock plays up in pairing time it is much like the play of the turkeycock; all his throat and breast feathers are bluffed out, showing the light and dark bands to perfection.

\section{THE GREAT BUSTARD.}

(Otis tarda.)

MALE.-The bill is light brownish-yellow; iris hazel. The head and upper neck all round are a light greyish-blue; on the upper part of the head is a brown band. The long moustache feathers are white; fore-part of breast grevish-blue fading into white. The principal quills are brownish-black with white shafts; the outer and secondary coverts, and some of the secondary quills, are white. The back and sides reddish-yellow, spotted and barred with black; tail white for a part of its length, then yellowish-red with two black bands; legs and feet are light brown. The bird's length from bill to end of tail is from forty, forty-three, to forty-eight inches.

The female has the band on the head lighter, the grey of the head and neck darker; the moustache feathers are wanting; in other respects her plumage is like that of the male. Her length from bill to end of tail is from thirty-two to thirtyfour and thirty-five inches.

The nest is only a slight hollow scraped or trampled by the female; sometimes it is in open 
situations, at other times concealed, or partly so, by the surrounding vegetation found in the magnificent bird's haunts. The eggs, generally two in number, are pale olive in ground-colour, blotched with reddish-brown and grey.

THE LITTLE BUSTARD.

(Otis tetrax.)

MALE. - The bill is brown, greyish-blue at the base; the iris reddish-yellow. Upper part of the head and the nape pale reddish-ycllow, varicgated with brownish-black. The throat and sides of the head are a light greyish-blue; a narrow ring of white on the neck is succeeded by a broad collar of black, below which is a half-ring of white, and another of black. The upper parts are pale reddishyellow waved with black. The edge of the wing, outer secondary coverts, base and tips of the quills, with all the lower parts of the body, are white. The tail is white at the base and tip, the other portion is pale yellow waved with black, having three distinct bands of the latter colour; legs and fect light brownish-grey. Length, from bill to cnd of tail, eighteen inches.

The female is about the same size as the male, but cliffers in not having the black markings of the male bird on the neck so conspicuous. The upper part of head, its side, and the neck all round pale 
8 WILD-FOWL AND SEA-FOWL OF GREAT BRITAIN reddish-yellow, variegated with dark brown, each feather having a broad midclle line, and several bars. Throat, yellowish-white; the upper parts are mottled as in the male, but the markings are larger. The lower parts are yellowish-white, with black lines on the breast and sides. 


\section{CHAPTER II}

THE STONE CURLEW OR THICK-KNEE

THE nest of the Stone Curlew, which comes to us in April and leaves us in September, is a slight hollow on the bare ground or turf, or it is to be found among stones or pebbles. The eggs, as a rule two in number, are greyish-brown or greyishyellow, dotted and spotted with purplish-grey and dark brown. In form and colouring they nearly resemble the eggs of the Oyster-catcher. The young birds run directly they are hatched, and they are covered with greyish down, with brown cloudings.

This fine bird, that appears to be a link between the Bustards and the Plovers, although fairly distributed in the season,- - for it is a migrant,-is confined to certain localities, principally to the castern and southern counties. It is, or at least was, particularly abundant in Norfolk, and on this account the name of Norfolk Plover was bestowed on it.

The bird in that county and in Suffolk finds its favourite haunts unlimited-I write unlimited pur- 
posely, for commons, rabbit-warrens, sometimes heaths and large open fields, are to be found there. As a quarry for a trained falcon, this bird is highly valued by some falconers. It has had to make the very best use of its strong swift wings very often in the counties I have mentioned; but frequently to no purpose, for the falcon with fatal stoop will strike it to the ground.

The first Stone Curlew on which my wondering eyes rested in boyhood days was shown to me by a shore-shooter who had shot it in the marshes; the birds bred there, and right away to their great breeding station in Romney Marsh. They may breed there still for anything I know; I have not been there since barbed wires were introduced in that locality. Barbed wires and natural history pursuits do not agree very well. That shore-shooter, a good old friend who has been at rest now for many years, was most patient with me, and his eyes, those dark-grey, far-sceing eyes, twinkled when a torrent of eager, jumbled-up questions rushed from my lips. With finger and thumb he parted the bird's eyelids that we might see the yellow, owl-like eyes; then he turned it about in all directions, finally stretching out the legs for me to examine. All this he would do to please a boy, who took far more interest in birds than in any other matter.

The Stone Curlew is not only shy, but it is as suspicious as a rat that has lost a fore-foot in a trap. It runs with amazing speed, and its flight is very quick and strong. The eye of the bird tells you 
that it comes out in the gloaming; but it can be seen in the daytime if searched for in the most circumspect manner.

There is no hard-and-fast rule rclating to wild creatures of crepuscular habits. 'The Brown Owl, for instance, spreads himself out like a feather screen for a warm air-bath, and he thoroughly enjoys it, although the sun is shining not only bright but hotly. I have seen him do it, not once but often. And the bats, the Noctule particularly, will hawk for insects with the swallows over the woodland roads in the latter part of a bright afternoon in early autumn; five o'clock is early for the beginning of the season. As to the fox and badger, they will at times draw very close, if you are near their haunts and they do not wind you. If a fox goes by you, rest assured you have learnt the art of keeping quiet.

It is the same with birds; you can study them at liberty if you can keep quiet, which some are not able to do. It is best to go alone, if you can lie stretched out in the ferns, your chin supported by your hand to raise the head a little, your hat off; and if you can bear a couple of stout flies at the back of your neck.

When under such circumstances as these I have seen what I crawled in there to see, I have afterwards jumped up in the most active manner, and have said all one could say on the subject to oneself, in the most cmphatic manner possible.

Not a sound, not even the faint tinkle-tinkle of a sheep-bell falls on the car ; church spires and hamlets, 
farms and cottages are below us, surrounded by the woods that creep almost up to the top of the Downs we are sauntering over; if we did not see one vestige of bird life, the view would repay us a thousand times. It seems useless to attempt a description of the South Downs; those who wish to know what the prospects from these are like must go there and see for themselves.

Stone Curlews have their habitat there now as they had in Gilbert White's time. A few remain at times, even in the winter; but the cause of their remaining we do not know. A few remained in our own marshes, when I was a boy; one that I tried to paint was shot in winter-time. For weeks I have known Down districts unvisited even by a shepherd: it depended on what parts of the Downs the sheep were feeding on.

I have never known any bird that nested on the ground coming to grief, when sitting, by being trampled on by stock feeding there. Instances of this kind may have taken place, but I have never seen it. When a ground bird is sitting, its eyes and ears are all alert, not even a tiny harvest mouse could crawl over or up a bent stem without the birds hearing or seeing it. You may stand within a yard of some, and see their bright eyes fixed on you ; but do not stop long, for even kindly human eyes disturb them if the gaze is too persistent. Restless movements of the shoulder feathers will show as the first signs of uneasiness, then the bird will glide off and away. A flock of sheep may be grazing round 
about a sitting Stone Curlew and never a feather be touched. A sheep could nibble close to a bird, so close that the bird would give it a gentle peck or a flirt with its wing as a warning to walk round it ; but a shepherd's dog would not get near the nest, for the birds know the difference.

In favourable situations, with a glass, you may get a good view of them for a short time, but not for long: the bird stands high on its legs, and it holds its head up at times in spite of its skulking habits; those bright eyes do not miss much. Even as you look something causes the bird to spring up and flight it. Important facts have been discovered by accident, and similarly some of my own most valued insight into bird-life has been gained in that way. After weary walks and the most patient watching, one almost stumbles over the creature when one is not looking for it or even thinking about it; and in the most unexpected places too, where you would never have dreamed of looking for it.

Here is a bare place, where turf has been pared some time or other, long enough ago for tuffets to besprinkle and for a few flints to crop up; for directly the turf is off flints begin to "grow," as the rustics term it; that is, they show above the soil. If the almost imperceptible movement of what looks like a flint had not caught our eye, we should have missed secing a couple of young 'Thick-knees. Our footsteps over the elastic turf had not been heard by them, and when we 
stepped off it on to the bare place we almost stepped over them: they were far too frightened to run, so they squatted, and as it were mimicked flint-stones. It was only their breathing caused us to notice them. Do what they will they are not able to conceal their alarm, and their bodies move very perceptibly when they breathe, telling you very plainly they are frightened, and that they would be very glad if you were gone. Never injure or kill any creature you are studying, nor capture, if you can possibly avoid it; for you might just as well destroy the pages in an unread book, and then expect to know what was in it. If you wish to know something of a creature's life, killing it will not inform you. One understands how there is so much speculative natural history about. A few facts are worth a score of the most elaborate theories.

A stretch of low grey-green uplands is lit up for a time with a dull tawny light, for night is near. The little light remaining is the last reflection from the after-glow of a marsh-land sunset. A mournful whistling cry is heard, answered by others of a like nature. The dull break of water can be heard on the beach below, and with it is mixed up the cries of birds. They come from gulls, cackling before they rest on the flats. If you linger here long you will feel a bit eerie, for all you will hear will be the plaintive calls of those bright-eyed coursers, the Stone Curlews. 


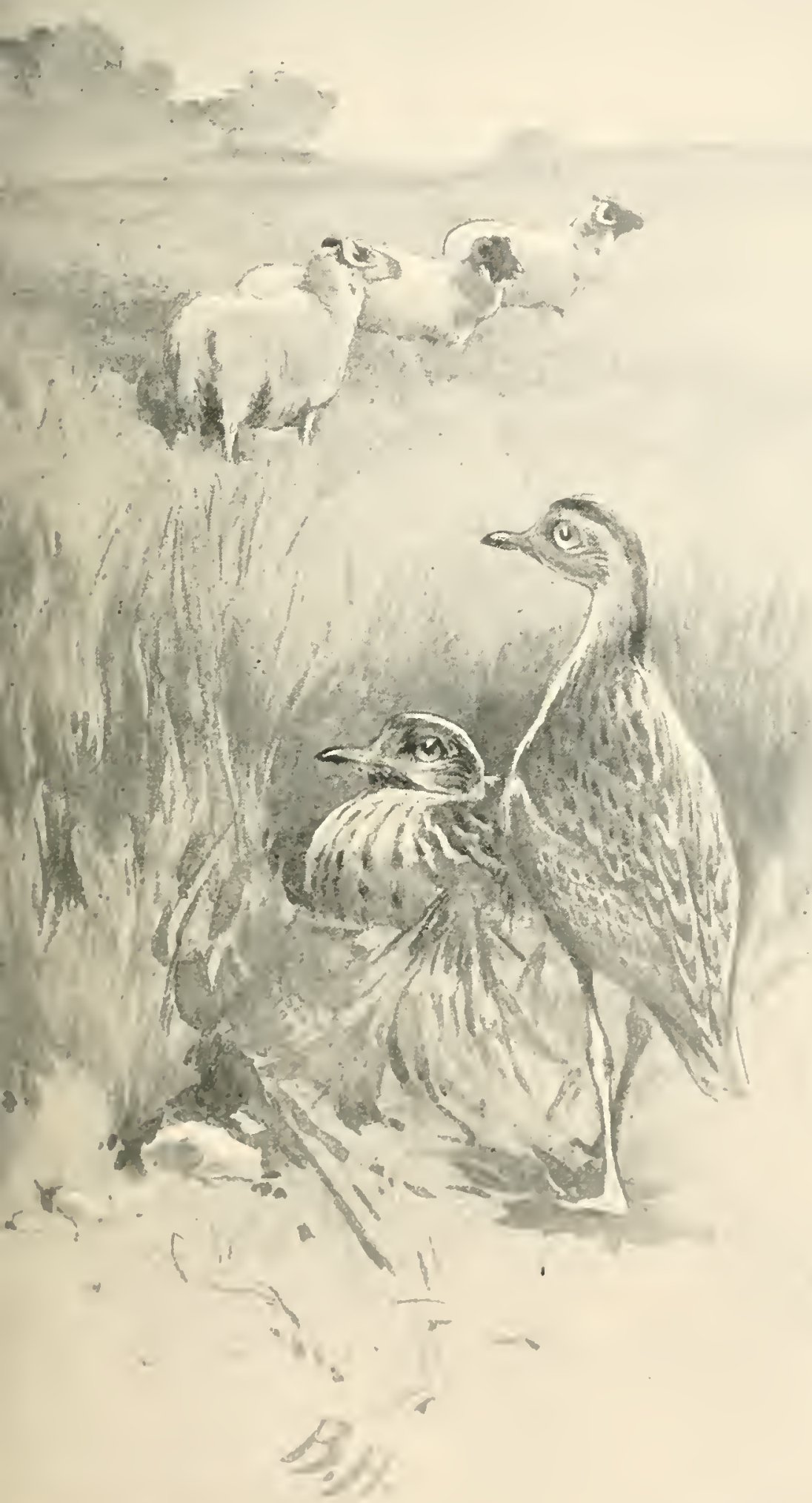



THE STONE CURLEW OR THICK-KNEE.

(Edicnemus Siolopax.)

MaLe. - The bill is yellow at the base, black at the end ; iris yellow ; upper parts of the plumage light yellowish-red tinged with grey, streaked with blackish-brown. Smaller wing coverts cream colour; tips of secondary quills white, primaries black; the outer two with a large white patch about the middle; tail feathers mottled with brown and pale reddishyellow, with more or less white towards the end; the tips black. A band over the eye and a lengthened band under it whitish, then a light brown band with dusky streaks; fore-part and sides of neck and breast light yellowish-red with dusky streaks. The middle of the breast and belly white; legs and feet yellow. In the breeding season the cock-bird has a knob the size of a large pea at the base of the bill; this mark only distinguishes him from his mate. His length from bill to end of tail is seventeen inches.

The female is like the male in plumage, but the knob at the base of the bill is wanting. 


\section{CHAPTER III}

PLOVERS

Tile Grey Plover does not nest in this country. Very frequently this bird has been considered by shore-shooters as a fine variety of the more common Golden Plover; this is a very natural error.

The breeding or nesting haunt of this bird was only discovered in $\mathrm{I} S 75$ by Messrs. Seebohm and Harvie-Brown, on the tundras above the limit of forest growth in the valley of the Petchora in North-eastern Russia. This is only one grand bird nursery; others will be discovered, all in good time.

This Plover frequents the tide-ways, and the marshes where large flats of mud are left when the tide runs out; creeks and bays that are filled by the tide brimful when it flows, and left almost dry at the ebb, are favoured by it. If the saltings that border them are rough, scattered over with stones, bents, tufts of blite and rushes, so much the better; for they will squat there as close, at times, as Partridges.

To a certain extent the range of this bird is more local than that of the Golden Plover; some shore- 
lines are fairly well frequented by them, others sparingly. It was so on our own coast; for the shooters when looking for heavy Plovers, "heavy as lead" was their term for them, used to work these rough belts just out of high-water mark, with their clever spaniels. Couples and single birds rewarded their close hunting; I fancy that the Grey Plovers on that part were only stragglers that had come with the flights of Golden Plovers and then separated from them; and that the difference between the habits of the heavy Plovers and the others was well known, their method of searching for them proved.

One day when out shooting, we heard a shot on one side of us and saw the shooter walk a little distance and pick up something. As he made tracks in our direction we waited for him to come up. To my question of "What luck?" without a word he produced from the pocket of his coat a fine Grey Plover, which had been carefully arranged, not crammed in. As he stroked the breast feathers with one of his fingers, he said, "Hold him in your hand and wcigh him; ain't he a heavy Plover? Heavy as lead."

Crawling over and through a bit of stuff such as I have mentioned, with mud-pattens slung at your side, and a gun to bring along too, is far easier to talk about than to do. Supposing you have done it, got on your pattens quiet as a mouse, and sncaked along that line of rotting piles, sea-weedcovered and winkle-dotted, to get at three or four 
Grey Plovers fceding out on the slub-what then? You are drawing nearer, and your back aches terribly through being compelled to stoop so. One more creep and there will be a chance, at least you think so. But that chance does not offer itself to you, for a yelper of a Redshank slips off the very end of the piles, where he has been listening to the suck of your pattens from the time you started. How he shrieks and darts down the creek! - and the Plovers go as well. No wonder that highly moral verses learnt in childhood come to mind, as we slowly walk back, quite upright now, and our feet feeling heavy as lead.

The nest of the Golden Plover is only a slight hollow on some dry spot on the moors the birds frequent, with a few leaves or grass-blades scattered in it. As is usual with the Plovers, the eggs are arranged with their small ends together, the groundcolour of the eggs being cream colour or greyishyellow, dotted, patched, and spotted with dark brown ; sometimes light purple spots are found on them. As the eggs of all birds that have coloured markings vary more or less, and the birds vary slightly in size, like common humanity does, I only give the usual types.

This beautiful bird is almost as well known in certain countries as is the Lapwing. Vast numbers remain with us throughout the year, merely shifting their head-quarters from the northern moors where they breed, to the lower country, as winter draws near. Hosts upon hosts of Golden Plovers visit 
this country from northern lands and leave us again ; all the birds of this family range wide. As to the countries they visit, some have been mentioned, but to attempt any definite arrangement of flight lines would only be futile; they are to be found in certain places for a time, and then they leave them, or they are at least supposed to do so; but the worst of it is, birds have been found breeding in most unexpected places, quite out of all bounclaries as given in scientific books on natural history. The less said about this the better.

I have seen this Plover in its various changes from summer to winter plumage; the mottlings during these changes on the lower parts are very beautiful. The northern visitors are deeper tinted in their feathering than are our home-bred birds. Those who have watched the changes in Starlings, from their dull nesting plumage to that of the first adult stage, will, I think, be reminded of the spotted and patched plumage when the Golden Plover's plumage is in its transition state.

Although they breed freely in the northern country and in Scotland, it is not often that they are seen on the hills or moors of southern countries. Great flocks shoot over, and some even settle for a short time, but they are up and away again. A part of one lot settled on a wide common I was walking over; these preferred the main road that ran through it to run on and pick about in. They were the tamest, or it might have been that they were the most tired-out bircls of that species I have ever 
seen; for they ran a few yards ahead of me like barn-door fowls, before they attempted to rise again. This is a gentle, bright-eyed creature, like the Dunlin that nests close to it on the moors. So closely does the Dunlin follow the Golden Plover that it has been called the "Plover's Page." Its well-known cry is in perfect harmony with the bird's surroundings; and indeed, in wild life sights and sounds do go together. From the nature of the bird's nesting stations, it is not likely to suffer from any enemies except Hooded Crows and Gulls; but these are bad enough.

The female of the Dotterel is larger and more handsome than the male. The latter takes the chief share in incubation, and looks after the young when hatched. This is exceptional, but it is not a solitary case. I remember that when some Stone Curlews were required for scientific purposes some years ago, a boy who knew the birds and their haunts well snared some on their eggs in the day-time, and they were all cock-birds.

The nest of the Dotterel is a mere hollow. The eggs, three as a rule in number, are very handsome, ranging from buff olive to buff in ground-colour, spotted and blotched and slightly sprinkled with grey. The same places that the Ptarmigan nest in suit the Dotterel.

These bircls used to breed in the Lake district years ago, and before me is a list of their stations. I shall only mention two of these, Helrellyn, 3055 , and Skiddaw, 3022 feet above the sea-level. 
The Dotterel is considered to be one of the quickest flighting birds known. It arrives here about the middle of April or the beginning of May, has a very short rest on the South Downs, and other open places on the coast-line, then it clashes off to its breeding stations. Naturally it is of a tame and confiding disposition, and so it has been called morincllus, the "little fool." If ever a beautiful bird has been harried this one has, and I regret to write that the persecution is still going on. This is because the feathers are highly valued for dressing artificial flies. Fifty years ago those who knew the nesting haunts said that if this persecution went on specimens would only be procured with the greatest difficulty. All this has come to pass and more. Collectors have been in some measure to blame for this. The Bird Protection Act has been passed, I know, but I very much cloubt-so far as Dotterels are concerned-if it ever reached 3055 feet above sea-level. Like the Kite, this bird is valued for its feathers. Nany a bird has been killed for its tail feathers and for nothing clse, for fly-dressing. I have secn those glorious fabrications called salmon-flics, and have been told that nothing but certain feathers from certain birds could be used for making them; but I will leave that subject to those who know more about the matter than I do.

In I $\$ 60$ it was noticed that the Dotterels were coming to us in decreasing numbers. If the same persccution is going on elsewhere, in order to supply fishing lures, we need not wonder at this. When 
birds that have been used to breed in certain districts once take it into their heads that the place or places are no longer fitted for them, they leave them, not to return again.

As this bird flights vast distances to breeding stations on the tundras of Europe and Asia, there is little to fear as regards its extirpation; I only refer to the bird in this country, where it has been treated in the most inhospitable manner for so many years.

Fields of old fallow lea, upland pastures, and the table-lands of mountains and high hills are favoured by the Dotterel as feeding-grounds; it is not a coast bird. At one time the Bustard and the Dotterel could be seen on the same feeding-grounds, and both are gone now. Kites, if required for aviaries, are brought from the Continent, so are their tails; and as it is necessary to kill the Kite to procure its tail, the thinning-off process is resorted to. No matter what you require, Bitterns or Little Bitterns, Night Herons or Egrets, you can get them all by paying for them; also Dotterels.

The eggs of the Common Ring Dotterel, four in number, are deposited in a slight hollow scraped out by the birds, arranged with their small ends together, above the tide-mark among the pebbles or gravel, and more frequently in the sand. They are very large for the size of the bird, greyish-yellow in ground-colour, covered with spots and dots, with small line markings; in fact they mimic the beach pebbles. This pleasing and most interesting little Plover remains with us in varied numbers, according to locality, throughout the 
year. The local names of Ring Plover, Sand Lark, Sandy Laverock, Stone-hatch, and Stone Plover are most appropriate, each in its way.

Sandy warrens just off the tide are favourite nesting haunts; it would be almost impossible to give a correct idea of this broken ground, which is tenanted by rabbits that swarm on the shingle of the beach to feed, when the night comes on, on the washed-up sea-weed. Sandy bits there are littered with pebbles, vicious little blackthorns that catch you and trip you up, if not very careful in your movements, mixed up with furze and brambles. These are the spots most favoured by the Sand Lark; for on such bare sandy spots as abound here the eggs are deposited. Unless the birds fly up just in front of you, as you make your way along, it is impossible to see them, so very closely does their plumage fall in with their surroundings.

No bird that I am acquainted with shows more anxiety for its eggs and young than the bird under notice. It is this extreme anxiety that betrays their presence; you hear a plaintive whistle, and the bird flits in front of you, settles down, and pipes. There it is, you can see it now as plainly as if you had it in your hand. It runs a yard or two away, then turns and comes towards you as if it meant to run close up to your feet; stops short, looks at you intently with its full clark eyes, and pipes softly, as if to say, "Don't come any nearer." But we do, for we feel inclined to sce some perfect acting on this proficicnt little creature's part. 
There it goes, one leg broken and a wing tipped; now both wings are crippled, and it tries to raise its uscless wings, but all to no purpose; it drops on its breast, throws its head back with the eyes half-closed, as much as to say, "I am done for." Nothing of the kind; it scuffles out of sight somehow, and you pass on. Presently you see a wounded bird trying to kecp from falling; it is no use, for the poor creature drops, spreads out its tail and wings as some species do at the last gasp, and lies there, to all appearance dead. It is nothing but sheer humbug, the whole of it; on a near approach the bird shoots up and away, piping in the most cheerful and contented manner: these consummate arts have only been gone through to lure you away from the vicinity of its eggs or young. You might, in fact, be standing over a nestling and not see it ; unless the toe of your boot caused the tiny creature to move from where it had squatted; when the young are alarmed they scatter out.

I have had many hunts after the Ring Dotterel's eggs and young in past days, and to little purpose; I have seen both, but not too often, although the birds were breeding in detached pairs all around my boyhood's home. For the whole of one afternoon did a pair of these birds baffle four of the keenest beach-hunters I knew, although the young ones were all piping for their parents, close round them. This is a matter of common occurrence. You will hear it frequently said, "We're goin' on the hunt for Sand Larks' eggs, but we don't expect to have 


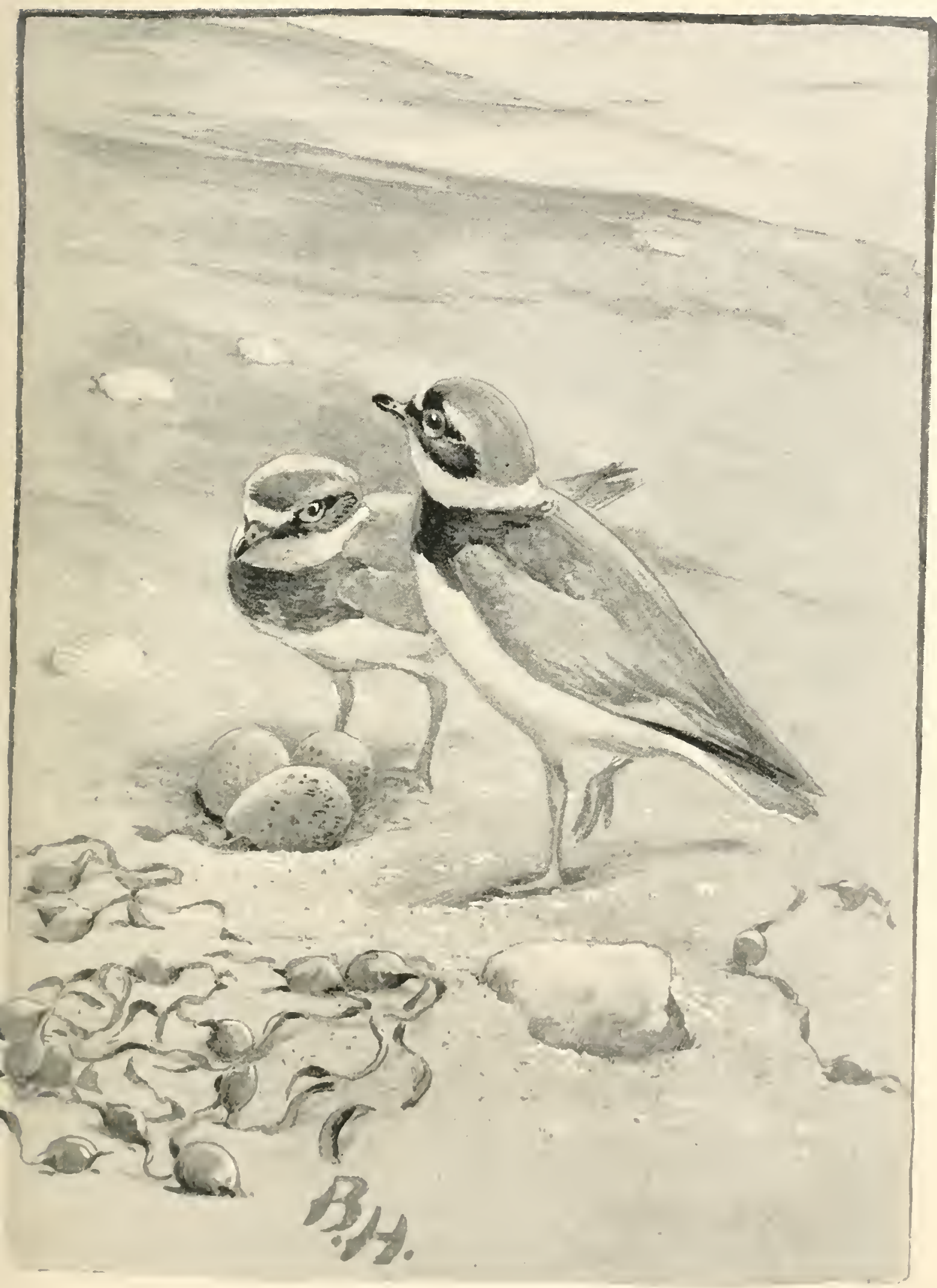

CUMMU: RAKEL DUTTLIRL. 

any luck." Those that are found, as a rule, are met with accidentally in the course of ordinary rambles.

A long line of beach runs sloping down to the tide; above high-water mark straggling posts show, some with fish-baskets on the top of them. These are fishing guides; one or two slope very much, which has been caused by the play of the wind on the old baskets, and the wasting away of the sand they had been placed in, for on some fore-shores sands are continually shifting more or less. Just beyond the old posts a rough track runs, dotted with stunted furze-bushes, which are nibbled down closely by the rabbits; then comes some coarse, broken ground, and the Downs lie beyond. The spot indicated was even in summer-time a very lonely one; no one passed there unless business matters compelled them to do so, for the rough track ran, as the few people scattered about there said, to nowhere; that is, to where no houses could be seen. I have been there for hours without hearing any other sounds besicles the lap of the waves on the beach below, and the piping of Ring Dotterels.

That this smart active creature should have been a favourite with lonely coast-dwellers was not to be wondered at; so very isolated were some of them that they had to row for a distance of five miles in their boats to fill their fresh-water barrels. I have seen them come many times to the mouth of a gencrous spring of coolest and sparkling fresh water that emptied itself direct into the tide. Before 
filling their barrels they would drink and drink again; to them that bubbling, sparkling water was life itself.

Water was all around them in the lagoons, in the fleets and dykes; this could be used for washing purposes, for it was not salt, and the greater portion not even brackish, but it was dead water; and those who were compelled at times to drink it suffered from ague and delirious marsh fever. I write always feelingly on the subject, for I have gone through it all.

There were only the birds to watch in the way of amusement; and even the Dotterels at certain seasons were conspicuous by their absence, for they have their times and seasons. The only motive in searching for the eggs was that they might be placed with others on those long loops and lines that all boys delighted to have at that time. The nests were not ruthlessly robbed, of any bird; one here and a couple there might be taken, as the case might be, to form their out-of-doors collections; they dared not get near the house with them, under heavy pains and penalties. A scrub-broom, a pair of pattens, a wet mop, or a bit of rope's end, no matter what, the first object that might come handy, would be used if a boy, in his eagerness to show another some new find, got too near the house with his treasures.

As I was generally the one to whom the fresh finds were shown, I had often to clear out as well. For our marsh-land folks would have it that dire 
misfortunes would happen to the community-ranging from shipwreck to the capture of a contraband cargo-if birds' eggs were brought indoors, or too near the house. 'This strange belief is alive and in full force still in some places known to myself. As the rare finds were generally the eggs of the Ring Dotterel, that they were hard to find became only natural. The nest of the common Lapwing, if a slight hollow can be called one, contains four cggs, of large size for the bird, but yet they are not so large as those of the Golden Plover. The general ground-colour of the eggs is brownishyellow, dotted, blotched, and spotted with brownishblack; but they vary like the eggs of other birds in their ground-colouring and markings. It must always be remembered, when reading about nests and eggs, that one should accept the general types of both; but due allowance should be made for variations, hard-and-fast rules do not obtain in these matters.

The Lapwing, or, as it is far better known, the Pewit, is one of the beautiful and common birds that remain with us throughout the year. Where plashy heaths and wide common lands border on cultivation, there you will be sure to meet with the Pewit. Fallow fields and turnip fields are his favourite feeding-grounds. These handsome birds are good friends of the farmers, for they feed on creatures which, if no check were placed on their increase, would injure the crops in no small measure. As the gentle bird's bump of self-preservation, so to 
speak, is largely developed, he rarely suffers from gun-shots. In fact the bird is credited by the country folks with sleeping open-eyed.

One thing is certain, if those who have to look after covers at night hear the feeding Plovers exchange their contented murmured "weet-weet-e-eweets," for the alarm note of "pewit-pewit-weet," they know that mischief is on foot somewhere or other. I have known keepers shoot a great many birds, but do not recollect a Pewit ever being one of them. So far as I know, there is never an instance of keepers shooting one of their natural night guards.

The great numbers of Pewits that are found in the markets are netted Plovers, and as netting is only practised by a limited number, so much the better for the Plovers. That model of suspicion, the Curlew, is also netted when he is required to be perfectly free from injury; to put in aviaries, for example. Rooks and Pewits may frequently be seen in company, large numbers of them feeding in the same field or fields; not that the Pewits have cause to love the Rooks over much, for in the breeding season the latter birds hunt for the eggs of the Pewits in the most persistent manner, as a delicate article of diet. Hooded Crows are never seen in some districts, so the blame is off their shoulders. If once Rooks get well acquainted with such delicacies, in spite of all the raps and buffetings the breeding birds may give them, they will get them if they can. So much were the depreda- 
tions carried on in one large field I know, that hard measures had to be adopted to stop them.

The Rooks used to fly over the hedge on to the main road to do their egg-sucking; but they dropped their eggs as quickly - it may be a trifle quicker-as they picked them up, for two or three shots rang out as they flighted over the hedge. Then you heard "quark-e-e-e, gorble gorble gorble, quark-e-e-e-e!" the death-song of the dying Rooks. After that they were taken into the field and spreadeagled out on the ground, as a notice to the others to-ware Pewits !

If the young Pewits remain perfectly still it is almost impossible to detect them; it is the overdone acting of the parents that betrays the young at times. For they roll and scuffle in a sad state of mortal injury close to you; probably if you chanced to look down, almost at your feet you would see the young birds. No one takes young l'ewits, for it is not only crucl, but perfectly useless. Two of our most interesting marsh-land sights were to see the Lapwings come on the flats to feed, and the Starlings go to roost in the reed-beds; for the bed-time of the Starlings was the feeding-time of the Lapwings. It was wonderful to watch two vast hosts of birds of different flight on the wing at one time, the flapping vecring of the Pewits showing, now black and now white, as alterations in their aerial mancuvres occurred; the rush and roar of the Starlings as they went through their sunset evolutions with military precision, 
like one bird; invisible one moment, a dark moving cloud the next, twisting, wheeling, rising, and falling, and at last making for the reeds with a rush and a roar like that of an express train. Then the babble, each one trying to out-chatter his neighbour; then silence, the silence of the dreary flats. Again, far out, a cloud of birds is loweringthey are the Pewits; they have settled, but even from where we stand we can hear the "pewit-weet-weet."

The Collared Turnstone is a handsome bird that appears on our coasts in October, leaving them again in May, although a few remain all the summer in Great Britain along the rocky parts of the coast. From their being seen at this time of year, some have stated that a few breed on our coast, but up to the present time this has not been proved. Some of these late-staying Turnstones have been shot for the purpose of examination, and although they were in what might be called summer plumage, they were not so handsome as those that shoot along the coast in May, on their way to their nesting haunts over the North Sea.

The bird has received its name from its habit of turning over small stones, sea-weed, and other refuse thrown up by the waves, where their food may be hidden. It is a nimble-footed and swiftwinged bird, a wanderer in the full sense of the word. The late Mr. Gould remarked-"If any bird may be regarded as cosmopolite, it is the Turnstone, for it inhabits the sea-shores of every part of the globe." 
The nest of the Pied Oyster-catcher is a slight hollow among pebbles or gravel above high-water mark, or on coarse ground not far from the tide. The eggs are large, from three to four of them, arranged with the smaller ends together, being greyish-yellow marked all over with dots, spots, and blotches of blackish-brown and amber, with some streaks of the same colour.

This handsome black - and - white wader and swimmer is called Sea-pie on the south coast, where it is only a visitor, and Mussel-picker in Scotland, where it is found all the year round. At times these birds gather in vast numbers, particularly in Sutherland, and as they are not interfered with, the vast flocks are quite fearless. Sea-pie is far more appropriate as a name for the bird than Oystercatcher, for strong as the bill is, and used by the bird in the most able manner, oysters are safe from it.

This bird may be seen at times with other fowl in the markets, but I think they are sent to hang up only to attract notice to more valuab!e birds by their very conspicuous plemage. In their haunts they enliven by their active movements and loud cries some very lonely places, where more seals can be seen than men.

It breeds on the stony or sandy beaches of the rivers in Scotland, in fact it is a common bird there: so very common in some parts, that no more notice is taken of finding a clutch of their handsome eggs on the shingle, than there would be in southern counties in finding a Thrush's nest. 


\section{THE GREY PLOVER.}

\section{(Squatarola Helietica.)}

MALE. - The bill rather stout, nearly as long as the head, black, iris dusky; the upper parts blackish-grey, variegated with numerous white spots along the margins of the feathers; those on the rump have a yellow tinge. Upper tail coverts white, with dusky bars towards the end. Tail barred with dusky brownish-black and white. The primary quills and their coverts are chocolate brown, slightly margined with greyish-white. The sides of the head, the neck all round, the breast and sides of the body greyish-white, strcaked with brownish-grey. The belly and lower tail coverts white, legs and feet greyish-black. This bird has a small hind toe, which the Golden Plover, the next on the list, has not.

I have given the details of the bird's plumage as it is usually met with. The breeding plumage, with the exception of the spotted parts of the feathers being white instead of brassy yellow, - as in the Golden Plover, - is very like that of the latter bird. Its length is twelve inches.

The female is similar to the male, only smaller.

\section{THE GOLDEN PLOVER.}

(Charadrius plurialis.)

MALE.-In summer the bill is black, the iris brown; the upper part of the head and fore-part of 
back are beautifully variegated with brownish-black and bright yellow; the upper tail coverts and the tail feathers are greyish-brown, variegated with paler yellow. The middle of the fore-neck and breast are brownish-black, bordered with white; the sides of the neck and body mottled with brown and greyishyellow; the forehead, a band over the eye, and the belly white; legs and feet dark bluish-grey.

In winter the male's upper parts are brownishblack, with very numerous yellow spots arranged along the margins of the feathers. The upper tail coverts are barred with brown and yellow; the tail feathers greyish-brown barred with yellowish-white; the lower part white. The wings are chocolate brown, the smaller coverts and inner secondaries spotted like the back; primary quills slightly tipped with greyish-white. The bird's length is nearly eleven inches.

In summer and winter the female plumage is very like that of the male.

\section{THE DOTTEREL PLOVER.}

\section{(Eudromias morinellus.)}

MaLe. - In the summer the bill is bluish-black, the iris brown. The upper part of the head is brownish-black, the feathers of the forehead margined with a white line over the eye to the occiput, where it meets that of the other side of the head. The throat is white, with clusky specks. The upper 
parts of the plumage are greyish-brown, the feathers having red edges; the fore-neck greyish-brown, a double band of black and white on the lower part of it, the sides and fore-parts of the breast red, with a patch of black behind. The belly and lower tail coverts are buffish-white, tail greyish-brown, dark brown towards the end. The length of the bircl from bill to end of tail is ten inches.

In winter plumage the upper part of the head is dark brown, margined with reddish-white, the upper parts greenish-brown, the feathers edged with pale red; forehead and cheeks whitish with dusky streaks; fore-neck grey-brown, a band of white at its lower part; thie breast, reddish-brown.

\section{THE COMMON RING DOTTEREL.}

\section{(Egialitis hiaticula.)}

Male.-The bill is black at the end, orange at the base; the forehead is marked with two bands, a black and a white. A dark brown band runs under the eye; a ring of white, including the throat, is succeeded by a broader ring of brownish-black. The top of the head, the back, and the wings are greyish-brown. The quills are dark greyish-brown, of a deeper tint towards the end; a bar of white crosses the wing; throat, breast, sides, and belly are pure white; legs and feet orange. The bird's length from bill to end of tail is from eight to eight and a half inches.

The female is similar in plumage to the male. 


\section{TIIE KENTISH PLOVER.}

(Esialitis cantiana.)

The Kentish Plover is smaller than the common speciesalready described, and from which it may be easily distinguished by its having only two patches of black in the place of an entire ring of that colour on the neck. The greneral tones of colouring are as in the common. The bird's length is seven inches.

\section{THE LITTLE RINGED PLOVER.}

\section{(Egialitis curonica.)}

This pretty creature is, as its name denotes, a dwarfed representative of its common relative, that courser and tripper over flats and sands which is so universally distributed, the Ring Dotterel or Plover.

As it is my intention only to describe in their haunts the game birds and wild-fowl that are usually to be met with, the rarer species belonging to their families will only be brichy noticed. Very rare visitors will not be noticed, for they do not belong to this country; and, as I said before, my sketches are not written from a scientific point of view, or on regular natural history lines.

\section{THE COMMON IAPIIING.}

(Fnellus inlgaris.)

MALE - The bill is brownish-black, the iris brown ; the upper part of head and crest are black, grlossed 
with green and blue. The sides of head and neck are white, but a black streak under the eyes. The fore-part of neck and a part of the breast are black, glossed with blue and green; the upper parts brownish-green, some of the feathers having purple and blue reflections. The primary quills bluish-black, breast and belly pure white, legs and feet dull crimson. The bird's length from bill to end of tail is thirteen inches.

The female is coloured similar to the male, the only difference being that the head and fore-neck are a little lighter, and her crest is not so long.

\section{THE COLLARED TURNSTONE.}

(Strepsilas interpres.)

MaLE.-The bill is black, the base of the lower mandible reddish; iris brown. The general colour of the upper parts is dark brown, glossed with green and purple, the feathers edged with pale brown; fore-part and sides of the head white, spotted with black; the throat white, a band on each side from the lower mandible. The side of head and fore-part of neck are black; lower parts pure white, as are the hind-part of the back and the upper tail coverts. Some of the rump feathers are black, the tail is white at the base, brownish-black towards the end. The primary quills and coverts brownish-black, legs and feet orange. Length, from bill to end of tail, ten inches. This is the usual state of the bird's plumage 
as met with here in the season. It breeds in northern lands. In the winter the middle of the back and the lower parts are white; fore-neck black, upper parts blackish-brown.

Female.-Similar in colour, but not so deep.

THE PIED OYSTER-CATCHER.

(Hamatopus ostralegus.)

MALE.-The bill is three inches long, vermilion tinged with yellow towards the base, the wedge end of it dull yellow, iris crimson. The eyelids are vermilion; the head, neck all round, fore-part of back, scapulars, wing coverts, quills, and encl-part of tail are a deep greenish-black. The breast, belly, side, middle and hind-part of the back, and the upper and lower tail coverts are pure white; a band of the same colour crosses the wing. The legs and feet are purplish-red. The bird's length from bill to end of tail is seventeen inches.

The female resembles the male in colour, but she is a little larger, measuring from bill to end of tail eighteen inches. 


\section{CHAPTER IV}

\section{THE RUFF AND THE REEVE}

When the Ruffs first arrive, about the middle of April, the frills round the necks of the males are but half grown; the tubercles on the face, the tufts, and the ruff disappear in July. The colours of the ruff in particular, as well as those of the body, are so varied that hardly two birds can be found alike.

The Reeve, as the female is called, constructs a flimsy nest in the centre of a tuft of swamp herbage, coarse grass, or sedge; the eggs being four in number, grey green in ground-colour, blotched and spotted with reddish-brown and markings of brown grey. The Ruff is polygamous in its habits, and during the breeding season very pugnacious.

At the present time there are but two or three localities where these birds remain to rear their young, and these we will not mention, for very good reasons, which the true bird-lover will understand. The marshes and swamps they once frequented have been reduced by the modern system of drainage to such an extent that very few places are now left, suitable for them to breed in. The catching of Ruffs 
and Reeves, as well as the fattening of them for the table, belong almost to the past, owing to the causes I have mentioned, notably the drainage of the fens.

To complete the description of the Ruff it will be interesting to my readers if I quote from the supplement to Montagu's Ornithological Dictionary, published in I8I3. Colonel Montagu states that he made a tour through Lincolnshire in order to make himself acquainted with the history of this singular bird.

"The trade of catching Ruffs," he says, "is confined to a very few persons, which at present scarcely repays their trouble and expense of nets. These people live in obscure places on the verge of the fens, and are found out with difficulty, for few if any birds are ever bought but by those who make a trade of fattening them for the table; and they sedulously conceal the abode of the fowlers, so much that by no art could we obtain from any of them where they resided; and in order to deceive us, after evading our inquiries, gave us instructions that led us in quite a contrary direction. The reason of all this was obvious, for after much labour and search in the most obscure places--for neither the inn-keepers nor other inhabitants of the town could give any information, and many did not know such a bird was peculiar to their fens-we found out a very civil and intelligent fowler, who resided close to Spalding, at Fengate, by name William Burtonwe feel a pleasure in recording his name, not only from his obliging nature, but for the use of others in 
similar pursuits-and strange to say, that although the man had constantly sold Ruffs to Mr. Towns, a noted feeder, hereafter more particularly noticed, as also another feeder at Cowbit, by the name of Weeks, neither of these persons could be induced to inform us even of the name of this fowler. The reason, however, was evident, and justly remarked by Burton, for he obtained no more than ten shillings per dozen, whereas Weeks demanded thirty shillings for the like number he had the same day bought of Burton. The season was far advanced, and we were obliged to buy some at that price from Weeks, for Burton could not then catch as many as we required. At this time we were shown into a room, where there were about seven dozen males and a dozen females, and of the former there were not two alike. This intrusion to choose our birds drove them from their stands, and compelling some to trespass upon the premises of others, produced many battles. By this feeder we learned that two guineas a dozen was now the price of fattened Ruffs; and he never remembered the price under thirty shillings when fit for table. Mr. Towns, the noted feeder at Spalding, assured us his family had been a hundred years in the trade; boasted that they had served George II. and many noble families in the kingdom. He undertook, at the desire of the late Marquis of Townsend (when that nobleman was Lord-Lieutenant of Ireland), to take some Ruffs to that country, and actually set off with twenty-seven dozen from Lincolnshire, left 
seven dozen at the Duke of Devonshire's at Chatsworth, continued his route across the kingdom to Holyhead, and delivered seventeen dozen alive in Dublin, having lost only three dozen in so long a journey, confined and greatly crowded as they were in baskets, which were carried upon two horses."

Nothing can more strongly evince the hardy constitution of these bircls than the performance of such a journey so soon after capture, and necessarily, fed with a food wholly new to them; and yet a certain degree of care and attention is requisite to preserve, and more especially to fatten them; for out of the seventeen dozen clelivered at the Castle of Dublin, not more than two dozen were served up to table, doubtless entirely owing to a want of knowledge or attention of the feeder under whose care they had been placed.

The marsh people were not very easy to get at when we lived on the flats; they were far worse in the time of the gentleman above quoted. When the draining of the fens was first proposed, the amphibious fen slodgers rose as one man against the motion; but it was no use, they had to go, as well as their precious Ruffs, if they would find a living. I have records by me stating that when some "furrin settlers" made fresh banks, to keep the water back, the fen folks broke them, and they watched the breaches with loaded duck-guns to prevent the new people from repairing them. These matters belong to the past; as draining continues, the Ruffs will pass away from the remnants of the fens. 


\section{THE COMMON RUFF.}

\section{(Machetes pugnax.)}

The male, in summer, has numerous fleshy tubercles on the face, two occipital tufts, and a very large ruff of long feathers on the neck. The bill is orange yellow, the end brown; the tubercles on the head are reddish-yellow, the occipital tufts purplish-black; the ruff is chestnut, streaked and variegated with black; in fact there is no end to the variations of these parts. The neck, breast, and sides are mottled with black and white; hind-neck and back mottled and barred with light reddish-yellow and brownish-black. The primary quills and coverts are dark brown, lower parts white; legs and feet yellow. Length of bird, twelve inches.

The winter plumage is very different; the bill being brown, iris hazel, upper parts variegated with brownish-black and light red; fore-neck and part of the breast pale reddish-brown, spotted with dark brown. The rest of the lower parts are white; legs and feet greenish-yellow.

The female is without tubercles or ruff. In summer the upper parts are greyish-brown glossed with green, fore-part of neck and breast paler, lower parts white. In the winter the female resembles the male, but the dark tints are paler, and the lower parts tinged with grey. 


\section{CHAPTER V}

SANDPIPERS AND TIIE SANDERLING

The Knot, called also locally the Ash-coloured Sandpiper, appears on our coast in the latter part of August, or the beginning of September. In this case, again, the female is larger than the male, her plumage is similar; the old birds usually show a portion of their breeding plumage when they first arrive, and some have been shot in red plumage. Where the Knots rush off to in order to breed is a mystery yet to be solved. The young Knots are coming all through August and well into September, whole hosts of them; when they first arrive they are most guileless creatures, but they soon learn to take better care of themsclves.

There must be a vast breeding ground somewhere, not yet discovered. They leave us and they return again, but where from is not known, this being one of the mysteries of bird life. They are to be found in great numbers on some parts of the coast-line, and they are eagerly sought for by gunners, for they are good birds to eat. If a large flock of them can be well got at, they are well worth getting. No 
matter how many are killed, they are here in full hosts again next season.

The Purple Sandpiper has not been found breeding in any part of Great Britain, although young ones with nestling down among their feathers have frequently been procured. This indeed proves nothing, as the young of other members of the Sandpiper family have been found in the same condition. That distant breeding haunt where they were hatched out has not yet been discovered.

This bird is known to breed in Iceland, the Faroes, and other northern haunts. I have seen many of these Purple Sandpipers in various stages of plumage, some of them not far removed from the full breeding plumage. This is not to be wondered at, for it does not take them long when their young are fit for flighting to dash over here from their nearest northern breeding station. On those parts of the coast that are suitable to them, they may be seen nimbly running over the rocks and boulders directly the waves break and recoil; in fact they follow the waves down, picking up their food from off the tangle and weeds that cling to them; avoiding the thundering rush of the returning waves in the most clever manner.

The Purple Sandpiper can swim; I never knew a wader yet that could not do so when it was necessary. Where lobsters, crabs, and congers are caught are the parts where this bird may be looked for.

Let me sketch one place where I have seen him. A long line of dark brown and olive-green tinted rocks, 
connected in some parts, broken up in others, of all shapes and sizes, with high rocks again behind them ; in some places great solid sloping shelves would run fifty yards or more in length without a break, covered with shiny slippery sea-ware, that I have failed to travel over bare-footed. So I have crawled over on all fours, a very undignified position certainly, but under the peculiar circumstances it was the safest. Then the rock fringe would break up, and in the hollows, full of clear water, you would see all sorts of beautiful weeds and tangle, dull crimson, orange brown, and rich green. "Sea-ware" was the name for it. There are but very few places a healthy lad will not explore if he has the chance, and I certainly did exploit that ugly rock fringe. Ugly for a fishingboat a little off her course, it was; and I paid for my own venturing there; my shins were terribly scarred, and my arms scratched all over through hunting for crabs in rock-holes, and for other things. I have found myself on my back in the most sudden and unexpected manner gazing at the sky above. Those weeds were treacherous to travel on, and I have managed also to slip into a hole between two rocks, up to my neck in water, when the tide was out. Here we could see our birds, for they fed on both tides, the ebb and the flow. Sometimes in one of the larger pools a conger of considerable size would be discovered: this was left in peace until we could meet with a fisherman or some stout fisherlad; for a fair-sized conger, from four to five feet in length, does not allow itself to be easily captured. 
There is another matter also to be considered: the bite of a conger eel is to be avoided if possible. When the tide was out the birds picked about the broken-up rocks and the tide-pools. They are not timid, so that they may be observed with little trouble. A couple here, one there, never in numbers at any time on that hard shore. At high tide the waves rushed up the shelving rock patches, broke up in foam and receded, pouring off in cataracts of hissing water. Then the Purple Sandpipers were busy.

The female is similar to the male, only larger. In summer, at least, their plumage is alike-the breeding state of plumage. The upper parts are glossy purple black, the feathers on the head with red margins, on the back red with white tips, lower parts white, spotted and streaked with grey. As I have stated, the bird is seen here, at times, nearly in this state of colouring. The Purple Sandpiper resembles the Dunlin generally, but his form is more robust.

That nimble, neat-looking bird the Dunlin has many local names, according to the districts the bird is found in-Ox-bird, Dorbie, Ox-eye, Purree, Sea Snipe, Stint, Sea Lark, Plover's Page, Red-backed Sandpiper, etc.

For some time this bird, owing to its very different states of summer and winter plumage, was a puzzle to our earlier ornithologists, and they made two distinct species from the same bird. To a novice it is confusing to hear on some parts of our coast 
Curlew Sandpipers, Sanderlings, Dunlins, and Stints in the winter plumage called by the one name of Stints. A friend of mine on the east coast, in writing to me said, "I have sent you some Stints." His Stints consisted of the three first birds we have mentioned. As this was only recently, local names are apparently as much in use now as they were forty years ago.

The Dunlin nests in this country on the northern moors, Scotland naturally being its chief nestingplace; and from the Dunlin's nesting close to the Golden Plovers in the same haunts, it has been called by the people the "Plover's Page."

It will be as well to give in detail the full breeding plumage of one of our commonest shore birds. Even in southern counties we have procured it when flighting; also the Curlew Sandpiper, just as the breeding plumage was changing. This was on the muddy edges of a large pool at the foot of a wooded hill, very close to a populous town.

The bill is black, iris brown, upper part of head brownish-black, the feathers margined with yellowishred. The feathers of the back are marked in the same manner; some of the scapular feathers are barred on the edges. A small part of the throat is white, the sides of head, neck, and nape are greyishwhite, marked with blackish-brown; the quills and greater coverts are greyish-black, the coverts tipped with white. The breast is black, or marbled with black and white; the rest of lower parts white. The legs and feet are a dark olive. 
The female resembles the male in colour, but she is larger ; in old birds there is scarcely any difference. between them as to plumage.

Dunlins may be met with in various states of plumage, for, like their near neighbours in the breeding season, the Ptarmigan, they appear in different colouring at the different times of the year. But the vast clouds that visit the mud-flats and slubooze at the mouth of great tidal rivers, and along the shores, are all in grey and white livery. A Dunlin can be easily distinguished from a Sanderling in winter plumage, if one little matter is borne in mind, but not else-the Dunlin has a small hind toe which the Sanderling has not. The nest is a slight hollow lined with bits of sedge or grass, and little heath twigs; the eggs, four in number, vary in groundcolour from grey green to greenish-yellow, or a brownish tint marked all over with patches and spots of amber brown and light purple grey. When they first arrive, the birds that are shot in their mottled plumage cause many animated discussions among the shore-shooters.

There was snow in the streets of our fishing village and on the roofs of the houses-deep snow. From the rough, cobble-patched parement it had been shovelled off into the middle of the road, and as there was not any traffic through the place this did not matter; for, as the fisher-folks said, when it thawed, all the snow water would run into the creek at the bottom of the long up-and-down main street. 
It was certainly "a most dead-and-alive look-out," as some of them were wont to remark; but some folks at least were stirring. For three fowlers stepped out from the Royal George Inn, with their long duck-guns under their arms; the locks, as usual, bound round with the leg of an old worsted stocking. Just as the three were tramping off, the jovial landlord remarked-

"Surely you ain't a-goin' without Splashey, be ye, Craft?"

"Well, me an' Baulk an' Josher reckins to, fur the last time as we had him out, the jealous-headed old fool druv a marble down his six-footer an' busted her ; his nose ain't got quite right yet."

"Well, cum back, an' hev jist a tot of my most pertickler ager-medicine at my expense. Don't go an' leave Splashey out on it. It was only yesterday, when he scooted orer for his mornin' half-pint o' porter, as he said he reckoned he'd slip down Chitney Ma'sh way, an' wipe sum o' yer eyes 'bout them ox-bircls. He's makin' a pair o' boots fur me: jist hark at him hammerin' at they soles on his lap-stone. I ain't in no hurry for 'em. One on ye go over an' tell him so. Git him rigged up, his new gun an' all, and then bring him over here an' I'll give him a good lot of this most pertickler. He was most mighty high in the shootin' line yesterday."

In a very short time Splashey made his appearance fully equipped for the Ox-birds, and as he smacked his lips over the ager-medicine he said "he reckined as he'd clo somethin' afore he got home." When they 
left, the landlord called Baulk back and whispered, "Let Splashey have a good pitch, fur he is most oncommon high an' mighty." Splashey was a good customer at the Royal George, hence the landlord's solicitude. Down the street, along the quay, with its snow-patched craft riding at anchor on the dark water, just on the turn of ebb, over one marsh, then the uplands, on and on, and at last Chetney Marshes, and the tide at low ebb, and the fowl. Those of our readers who may have fowled on the tide there will, I think, bear me out in my statement that for henfooted fowl - the waders - the place was hard to beat, at the same time it was a dangerous one. Mobs of Curlews, clouds of Dunlins and other birds mixed with them, and the Saddle-backed Cobs, the Blackbacked Gulls, were continually beating up and down, well out of gun-shot, on the look-out for crippled fowl. When the tide is dead out, cuts and gripes remain, that may be crossecl ; for the.bottom is in all of them paved with broken shells and stones, but only in certain places where they drain at the mouth of their inlets into the tide at its lowest ebb. All round and above these cuts long tongues of sand, shingle, and mud run in all directions down to the tide.

Just off thesc spits, well within gun-shot, the fowl flight by in thousands. The tide ebbs and flows here with startling rapidity. The to all appearance solid spits of sand, directly the tide turns-although it is still at some distance-begin to ooze up and bubble; you can see it shift about your feet. If 
in the eagerness for one more shot you have stayed a little too long down with your fowl, dash through the mouth of the inlet, now knee-deep, wade up the slub, and consider yourself lucky that you have gained the sea-wall.

Now the worthy host's last injunctions had nothing sinister in their meaning, but he was confident that Splashey, who was a far better shoemalier than fowler, would do something as usual to make the frequenters of his house laugh again; it was well to keep things going cheerfully at his pub. As is the rule, each of the fowlers had posted himseif along shore, well out of range one of the other. Our friend Splashey had his post all right; but no, he must, as he termed it, "wipe t'others' eyes if possible." Had he waited, the fowl, as the tide made, would have flighted along shore; but he could not do that. For the clouds of Ox-birds showed, now white now dark, as they turned just beyond the spit. It was too much, Splashey walked out on the hard slub, crossed the mouth of the cut, gained the spit, and there he was in his glory. As he afterwards remarked, in what was meant to be the most private manner, "all he had got to do was to load an' fire." But he had been too busy to notice the tide, and the first intimation of discomfort he had was his boots sogging in the shifting sands that he was standing on.

He rushed for the mouth of the cut. Too late! his retreat was cut off; there was ten feet of water there if a bare inch, and Splashey could not swim. 
So he rushed up on the spit, and yelled his loudest, as indeed he needed weli to do. Fortunately the shooter nearest to him heard his voice and hailed the others. When they arrived, he told them that he "reckoned as Splashey was dumfoundered up, middlin' close handy."

Then they caught sight of him standing like a post, holding on to his long duck-gun which he had pressed down into the sand, a mass of seething water between him and the shore.

"There's a smack in the crick with a skiff at her painter-off you go, Baulk, hail her!" roared Craft ; "tell'em the d-d old skate Splashey is a-drownin'."

"Hold on to yer gun, ye old fool, or I'll half kill ye whin I gits to ye; do ye hear? Stan' up! I'm a-comin'." Then the measured pull of oars could be heard in the rowlocks-pulled at best speed - and a boat shot out of the creek and made for the spit. "Hold up fur a minute; if yer slips or lets go yer gun, I'll be the death on ye," again roared out Craft, utterly ignoring the fact that it was impossible for him to get near, or to render any assistance.

A few more strokes, and the boat shot up her bows, grounding in the sand at Splashey's feet. Covered well with water, to say that he slipped into the boat would be wrong, for he simply threw himself into it. This caused Craft to roar out-

"Knock him down, Baulk, with yer oar, or he'll scuttle the boat."

Very coolly Baulk took hold of Splashey's coat- 
collar with both hands, lifted him up, and then plumped him down, at the same time daring him to move. Equally coolly, he pulled the barrel of his gun out of the sand and placed it in the boat. "Give way!"

In a few moments Splashey was on solid ground with his true friends. The first thing they did was to shake hands with him in the most hearty manner congratulating him on his escape; then, with tha' strange contradiction common to human nature, they swore again at him in the most plain terms. They'd "a good mind to chuck him in agin, and drown him fur a powder-wastin' old fool."

Baulk suggested "ager-mixtur"; but "Where from ?" he was asked.

"From the locker's," very coolly answered tha active dyke-leaper.

Now, although that Looker had in the course of his "dooty" threatened Baulk with dire marsh-land vengeance when he trespassed, he now handed him a dumpy bottle with a smile, merely remarking "it would be a pity to lose Splashey, for he made fustrate boots an' shoes."

When he could hold his head up a bit, for he had been terribly unnerved, Craft asked him if "he'd bin takin' lessons in jumping from his old tom-cat." It looked like it the way he got in the boat; and another, in mildly sarcastic tones, asked him if "he thought he was tater clibbin' when he stuck his gunbarrel into that 'ere sand-spit, and why he had let all his fowl float away?" 
To all this banter Splashey merely replied that he should like a drop more "ager-mixtur," if any was left. When they got him home he was got to bed as quickly as possible; but it was some time before the lap-stone was heard to rattle again beneath his hammer.

The kind-hearted host of the Royal George remarked that many a true word was spoken in joke at times; but when he said, "git Splashey a place, he never reckoned as the old feller was a-goin' to pick one out fur himself like that ; but he'd find the old boy in ager-mixtur till he came to hisself again."

Splashey never went fowling after that incident. I had the pleasure once of hearing him relate his experiences on that sand-spit. According to his account, he shot so many fowl that they would block up a sluice-gate if they all drifted there. One thing was noticed, if Josher, Baulk, or Craft were near he could never be coaxed to speak about that day's sport.

The Dunlin or Ox-bird can be found in numbers all round those coasts suited to its habits. So far as my opinion goes, its flesh is certainly eatable, but not particularly good. Shore-shooters would miss the Dunlin, if it left us, for there is a sale for them. There is not the least fear of their being thinned off; their numbers are legion.

The various factories now to be found in so many places close to the edge of the tide have naturally caused them to visit some of their once noted haunts in diminished numbers; simply because their food- 
supply has fallen off; the main bodies now go elsewhere. It is, I think, onc of the most interesting of our sea-shore birds, being so very active and clean-looking.

Very often when the tide is out, and the great dreary mud-flats are bare, the Dunlins are the only birds that enliven them. Bare flats are depressing to look at without life of some kind. But these fowl whirl over them, up and down and across, now here, now there, at one time feeding or running about, then up and away; for ever on the move. Some of my most pleasant and valued experiences have been gained when watching the quick-winged and nimble-footed Dunlins.

The winter plumage of the Curlew-billed Sandpiper is very near that of the Dunlin that it feeds with, for we have killed both birds, when we fired at what we thought were Dunlins only, that ordinary fowlers would have picked up as Dunlins. Of course the white upper tail coverts would distinguish it from the Dunlin; but when a northeaster is blowing and salt spin-drift makes the eyes water, trifles are not noticed. Another matter is that we have shot old Dunlins with the bill bent downwards nearly as far as that of the Curlew Sandpiper. This bird has never nested in any part of the United Kingdom. The female resembles the male in both winter and summer plumage, but she is larger.

The Curlew Sandpiper has the same habits as the Dunlin, in fact if fowlers would examine their 
birds a little more closely, they would in many instances find they had got as many Curlew Sandpipers as Dunlins in winter plumage.

The Little Stint is a neat little wader, very like the Dunlin in plumage, the black patch on the breast alone excepted. It is a feathered wonder, nesting on the Siberian tundras and other parts of Arctic Europe. These birds are great flighters, being met with in Africa and India. They visit the eastern and southern parts of our shores; Sussex especially at one time, before the mud-banks and flats were reclaimed, was visited by Stints in considerable numbers. As this miniature Dunlin, as it might be called, mixes with them, it very frequently gets into the shore-shooter's bag. This is nothing surprising, for when hosts of sparrows in late autumn frequent the fields where corn has been cut and carried, if you fire at them you will find other bircls drop besides sparrows, that have been feeding with them on the same kind of food. And that is the reason why Dunlins, Sanderlings, Curlew Sandpipers, and Stints have all fallen to the shot when we have been fowling along shore. In dead winter they all feed alike, and frequent the same flats and slubs.

I have seen this bright, dashing little wanderer in summer plumage; it does not take it long to shoot from Norway here; possibly the bird may yet be found nesting nearer home. Some of the almost unvisited rock-stacks that it is impossible to get near, except under the most favourable circumstances-and then one has to leave them again in 
the most hurried manner-are covered in their rifts and hollows with a vegetation peculiar to themselves, providing ample cover for birds. Grass grows on all these stacks; and the situations are certainly very high. Those competent to judge think that, if certain dangerous rocks could be properly explored in the breeding season round the coasts of Scotland and the wild western coasts of Ireland, some at present obscure matters respecting bird life might be cleared up.

But the question is, how to get there? And a still more difficult one would be, how to get away? Those that have sailed there will understand what I mean. When I have picked up a small Stint I have wondered that a little wader, only six inches long from bill to tail, should be able to travel so far; but on examination I found there was nothing to wonder at, for the bird is exquisitely formed for achieving long journeys.

The upper parts of the Common Sanderling's plumage varies; this is owing to a mixture of old and new feathers; the full winter plumage is completed by December.

Before leaving this class of birds, so very difficult to clistinguish at times, let me advise my readers never to differ with a fowler about names; for he has known the birds by the names he gives them from his childhood, and so has his father before him. No more deadly insult can be offered to him than that of a stranger coming and assuming that he knows more about the birds than himself. The 
most costly fowling-piece will not get you a shot at fowl; but the fowlers can and will procure this for you, if you do not air "book-larnin' on birds" before them.

I have known some men to be placed in very awkward predicaments by this kind of thing; once let it get hinted that a "knowin' cruiser" is about and the job is done. Something is sure to happen, even when the gun is raised to the shoulder, to spoil the shot. A plank pulled on one side of a marsh-cut, for instance, is a serious matter in the dusk for those who get there, for the mud sticks. Class your birds at home, after you have got then, or the fowlers have got them for you. When I was younger, I was guilty myself of leaving one person in a very queer fix for knowing more about fowl than I did, after he had got me to go out with him.

\section{THE KNOT}

\section{(Tringa canutus.)}

MaLE.-The bill is greyish-black, margins at the base of bill reddish. The upper part of the head, a band from the bill to the eye, the hind-neck, fore-part of back, scapulars, and wing coverts are ash grey; the middle of each feather is dark grey. The hindpart of the back and upper tail coverts are white, with curved bands of black; the tail ash grey, the lower parts white; cheeks and fore-neck greyish, marked with dark grey lines; legs and feet greyish-blue. 
Length from bill to end of tail, ten inches. This is the plumage of the Knot that is usually met with here.

The full summer plumage is quite different. The bill is black, head and lower parts light red; some of the feathers along the breast and belly white. The upper parts purplish-black, the feathers margined with light red, on the hind-parts tipped with white. The primaries greyish-black; tail ash grey, margined with white. The eggs of this bird are not known.

THE PURPLE SANDPIPER.

(Tringa striata.)

MaLe. - The bill, a little longer than the head, is black, its base orange; iris brown, eyelids white, the head and neck purplish-grey; throat and line over the eyes white. The back is glossy brownishblack, with rich purple reflections, the feathers margined with greyish-white. The primary quills greyish-black edgred with white; legs and feet yellow. Length, eight inches.

\section{THE DUNLIN.}

\section{(Tringa alpina.)}

Male. - The bill, a little longer than the head, is black; iris brown. Upper plumage brownish-grey, each feather having a clusky central line; sides of head and neck similar, the fore-part of latter paler in colour. From the bill over the eye there is 
a greyish-white streak. Throat, breast, belly, and lower tail coverts white; tail feathers ash grey; upper tail coverts blackish; legs and feet dark olive. The bill is slightly bent down at the end. This is the winter colouring, and the one in which the Dunlin is usually seen on our coasts.

\section{THE CURLEW-BILLED SANDPIPER.}

\section{(Tringa subarquata.)}

Male. - The bill black, half as long again as the head, and considerably bent down towards the end; iris brown; upper plumage brownish-grey, each feather with a dusky streak. Sides, fore-part of neck, with a small portion of the breast, greyishwhite streaked with brownish-grey. A greyishwhite streak from the bill over the eye; upper tail coverts white. Primary quills and coverts greyish-black; secondary coverts grey tipped with white; tail feathers grey. Throat, breast, belly, and lower tail coverts white; legs and feet dark olive.

\section{THE COMIION SANDERLING.}

\section{(Calidris arenaria.)}

Called in different localities Ox-bird, Curwillet, Stint, Sand Lark, and Towilly. In its winter plumage so very like the Dunlin that ordinary observers would not distinguish the difference between the two birds. The summer plumage is different. Bill 
black; iris dusky; upper part of head black, margined with light red and white; cheeks, neck, fore-part of the breast, and sides greyish-red streaked with black. Feathers of the back and scapular black in the centre, and light red towards the edges, which are white; the two middle tail feathers black, margined with red; the rest grey, with lower parts white; legs and feet greenish black. Length, from bill to end of tail, eight inches. Female.-Similar in plumage to the male. 


\section{CHAPTER VI}

GREAT CURLEW AND WHIMBREL

The Great Curlews nest on the ground in a hollow, under the shelter of heath tufts or stunted willows, torey grass, or any other short moorland cover. The nest is composed of dry grass, twigs of heath, or other plants, and is what might be called slovenly built, but it answers the builder's purpose admirably. The eggs, four in number, are very large, being three inches long; they vary in groundcolour, being light olive or greenish-grey, or dull yellowish-brown, spotted and blotched with umber brown, very thickly sprinkled at the larger end; even the eggs vary in size.

This long-billed, long-legged, wary bird is associated with wild scenery; be very sure that the wailing cry of this most astute member of the wader family will not be heard where cultivation shows. I heard him in my carliest years, so early that I have tumbled into the tide looking for him before I was fit to be trusted forty yards away from home. I had been shown one, and told where the man had got it ; and so, child-like, I started off full of faith that I 
should see one alive at the bottom of the tidal street. I reached the tide all right, but pitched into it head first, and got hooked out, but no Curlew had made its appearance.

A fine specimen is before me as I write, which one of my fowling friends sent to me, so that I may have my memory refreshed a little. It is necessary to be pretty definite in asking for certain birds. Once I required a Gull; the result was a large basketful of live Cobs, and they were very lively incleed.

There is a coast saying, not confined to our particular part of it, that any man that has killed seven Curlews has killed enough for a lifetime. I have known six killed at one shot from a shoulder gun, but it was a most exceptional shot; some fell in the water, rough water too it was; but the shooter was his own water-spaniel, and he plunged in and gathered his birds. If he had not done so, the Cobs, the Black-backed Gulls, would have gathered them for him. In some parts of the coast, birds in immature plumage beat up and down the tide; great brown speckled creatures these are, and as voracious as vultures. It is most exasperating after a dirty crawl only to cripple a Curlew, and then to see him drop on the waves just out of range of a fowlinggun. There he is, you can see him, but you will never get him, although the wind is cleat on shore. and it is high tide; for those two bircls coming up with rapid beats of the wing are Cobs: their lieen eyes saw the effect of that shot a long way off, and 
they mean to profit by it. You may fire if you like. but you will not frighten them; they know as well as you do that they are well out of gun-shot. They lower their flight, drop their feet down, and settle one on each side of that Curlew.

Then you hear a fierce cackling, and see the Curlew lifted off the water and carried along between them, the Gulls' wings threshing against each other. Their prey is clropped; some digs from their powerful bills and a few shakes are given, and it is all over; and a few bunches of feathers go canting away over the ticle. For a few minutes the birds float, no doubt wondering that their prey has gone so soon. Then they flight once more, quite ready for a duck next time if they can get one, or for some deacl fish that has been washed on shore. One would not know which to give the palm to, for being wide awake; Cobs or Curlews are both hard to get at. As a rule, Curlews, when the tide is full, visit the upland sheep-pastures, or the fields with root crops. A few fine old birds feed in the gripes just off the tide; it is thesc odd birds that get the number of their mess wiped out at times. Now and then they are a little out of their reckoning, but it is dangerous work going after them, the surroundings are so treacherous; it is wild sport, that is all one can say for it. If I had the choice between a Gull and Curlew, for eating, I should unhesitatingly pick up the Gull, although he has been called a carrion feeder. Domestic ducks are not very particular what they cleal with, yet no one calls them 



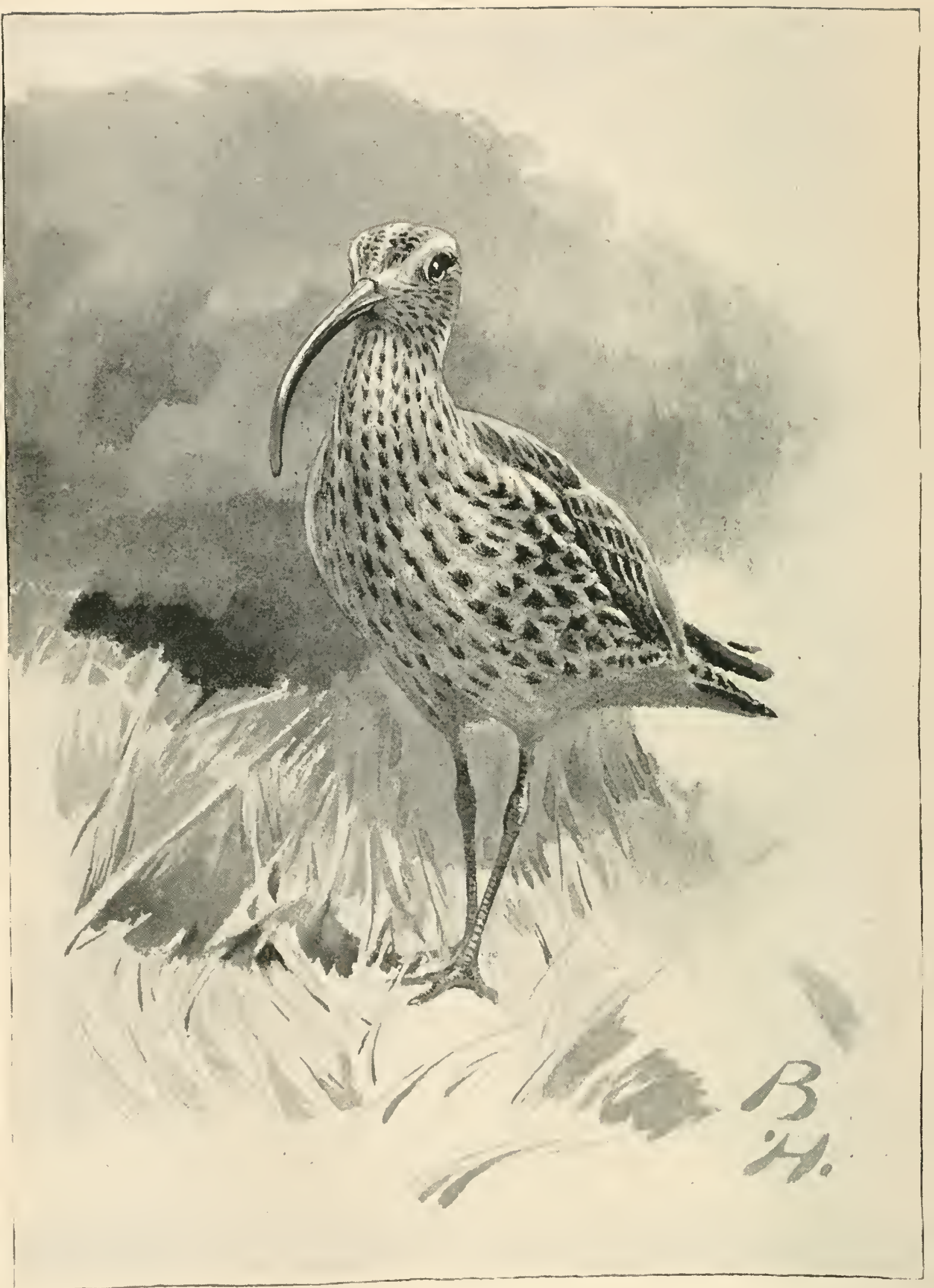


coarse feeders. A well-fed Gull has a coat of fat on the body, take that off before cooking, and you may wish you had more of Gull.

A long-billed bird uses his bill with as much dexterity as a short-billed one, only for a different purpose. The Curlew's food is varied to a degree; it consists of small creatures left in the tide-pools, some of them not more than one inch deep in water, sand-worms and hoppers. When he leaves the tide for the upland pastures, small snails and insects form his fare, worms also, and on the moors some of the wild berries in their season.

In Scotland this bird is called the Whaup, and it is considered in some shape or way as a feathered evil ; why, I have not yet been able to learn, although the legendary lore of Scotland has interested me for many years. The old form of supplication to be delivered from all "lang-nebbed things o' evil," included the wary Curlews. Witches and warlocks were always represented as having long hooked noses, and the Curlew has a long curved bill; but the real reason I should imagine would be that wild cry of the bird when heard through the mist, the bird itself being unseen. In time no doubt this superstition about the Whaup will die out, but not yet awhile. England too has some superstitious views of bird life that are in full force still. There is a folk-lore of natural life common to the United Kingdom that one would be very sorry to see pass away. No true naturalist yet but what was well 
acquainted with the folk-lore of animals and birds. I do not refer to scientists.

When the Curlews feed in the turnip-fields, they come to grief, for the large leaves hide the birds. Not that they are not on the look-out; but the view from the leaves is limited, a pointer and doublebarrel will stop a couple, or, if the shots are very favourable ones, it may be more. To look at, after they have been shot, they are fine brave birds; but it is their feathers that make them look large. When picked, there is not much serious feeding to be got from them. Wild-fowl dinners are exactly like fish dinners, very unsatisfactory, and of little value if you have not dined off a joint first. Any healthy youngster would eat the whole of a wild duck, especially if he were what the old ladies call a growing lad.

Sometimes on the bare uplands those who tended the sheep made wattled enclosures to give partial shelter when the winds blew keenly from the tide; if artificial shelters of some kind are not formed, the sheep wander and find "loo" places for themselves. When one or two Curlews got near the sheep, these shelters could be used by the shooters in order to make up to them, but if a companion flighted over, the alarm was given instantly and off went the lot. If things went on rightly, there was the crawl inside the wattled hurdles, then the peep through. Yes, there is a fine fellow, he appears to be picking up little shell snails; he picks something up every now and again, holds his head up so that he can pass it 
along his bill until he can swallow it, and that done he searches for another. He is there, and so are you; move you dare not, for there is no chance of a shot yet. Your quarry has run farther away; but something is not quite to his taste, he comes back just within shot; something has made him suspicious, for his head is up. It is no use yet; rise you must not, he may turn his back and feed again. He does so, and now for it! The gun is clear for a rise, but directly the top of a cap gets above the hurdles he sees it, and rises screaming with fright, as a Curlew can scream. Missed after all! Shot above him as he went away. What's that crack? He's down with a broken wing, one or two pellets hit him on the wing-bone and it has snapped; but not near the body : it is a very bad case of wing-tip. Now catch him! Do not hurry at the start or you will be winded; that Curlew is in better racing trim than you are.

Take it steady! How he does run and scream; putting up a covey of Partridges and a trip of Ring Dotterels that had come here from the tide, as they so very often do. After a long run he gets entangled in some creeping brambles and we get him; not to kill, for he may be got to feed, and I think he can be studied for a bit. The wildest birds are the most confident, if you can but get them to eat.

Bircls, like common humanity, are seriously influenced by hard times. I hare seen mobs of Curlews when food was in profusion and all went well; and they were as cautious then in prosperity 
as at any other time; it is the nature of the bird to be so. Those who have met with him on dreary shores where he certainly has never had cause to suspect mischief, have found him as wary there as on our own shores. Even in hard times, - hard for all created things, - when the starved birds wailed and cried, and their feeding-grounds were uncovered only to freeze again before they could get their crops a quarter full, they were as suspicious as ever; although no one shot at them, for the simple reason that they were not worth wasting powder and shot over. They had just got strength to flit from place to place, and that was all. When the weather did break, in about three days they were as brisk as ever, for this class of birds feeds day and night after a fast, as the tide serves, in order to make up for short commons.

I do not wish my readers to think that I have braved worse weather on the coast than other people, but I have been out when the weather was quite bad enough, by night and by day. I have seen statements made that certain fowl feed by day, others by night; I know this is true, as a rule, but there are no hard-and-fast rules with shore-birds or water-fowl; they feed how and when they can best get it. When the Gulls rush on the fields like Rooks, and feed there, one may see great grey and white patches of them. Shore-birds go on short food. I have seen three feet of shingle on some of their feedingspots, and there it remained until a contrary tide to the one that had hurled it there swept it away again. 
Curlews have been the means of my exploring wild places; where, if I never shot a Curlew all the day, I did other birds, just for specimens, and I observed far more. If there is one bird one may respect for being wide-awake, it is the Curlew.

The Whimbrel or May-bird is the Jack Curlew of the shore-shooters. The female resembles the male in colour, but she is two inches larger than he. These birds, like their larger relatives the Common Curlews, vary in size, so that it is best to give in all cases the ordinary measurements. Whimbrels are seen about the coast-line in May, and for this reason they are in some places called May-fowl. In early summer, and in autumn too, they are met with, previous to their departure. The Whimbrel has been known to breed in Shetland, leaving again when the season is over. My own personal observations of him have been made from the deck of a vessel, drifting down mid channel in a dead calm, when the tide was at its lowest cbb. There was not the least need to use glasses, we were quite near enough for any purpose, well within gun-shot.

Had the boat been brought over for a shot, the fowl would not have been gathered, for no one would have ventured there. The whole length of that slub-flat, left bare at ebb tide, was full of slushmud quakes that a boat oar would not fathom. The fowl knew they were safe when the ticle was out, so they frequented the slub there in considerable numbers. Bright-looking creatures they are, as they run and dabble about; when on the wing the white 
part of their backs shows very conspicuously. They have a sharper flight even than the Great Curlew; not many are brought to bag in the season, either of Jacks or full Curlews; in some parts and seasons not a dozen, all told.

\section{THE GREAT CURLEIV.}

(Numenius arquata.)

MALE. - The bill is flesh colour at the base, the rest black; iris brown. The head and neck are light yellowish-red, tinged with grey, each feather having a central blackish-brown streak; the forepart of back and scapulars are darker, the dark markings broader, and continued to the tip of the feathers. Small wing coverts lighter, but similarly marked; primary coverts brownish-black, with the tips white; primary quills are deep brown, the first with a white shaft. The first five quills are unspotted on the outer web, the rest spotted; back white, with lengthened dark marks; upper tail coverts barred with black. The tail is white, tinged with red towards the end, having twelve brownishblack bands ; breast, sides, and belly white, the first spotted, the second with broader spots and bars; legs and feet blue grey. The bird's length, from tip of bill to end of tail, is twenty-five inches.

The female is similar to the male in her plumage. These birds vary in size; some reach twenty-seven inches. 


\section{THE WHIMBREL.}

\section{(Numenius phropus.)}

Male. - The bill black; base of lower mandible pale brown ; iris brown. Upper part of head dark brown, with a central streak of brownish-white, mottled with dusky colour, and on each side a streak of the same passing over the eye; eyelids and chin whitish. Sides of head and neck greyish-white, streaked with brown; fore-part of back, scapulars, and wing coverts dusky, with whitish spots. Primary quills dusky, spotted along both margins with white; hind-part of back white; tail and coverts greyish-white, barred with dusky colour. Fore-part of breast streaked with dusky colour; hind-part of breast and belly white; legs and feet blue grey. Length, from bill to tail, seventeen inches. 


\section{CHAPTER VII}

\section{MORE IVADERS}

TuE Bar-tailed Godwits are also called May-birds on some parts of the coast: local names are often slightly confusing. The names May-bird, Poor Willie, Stone Plover, and Yarwhelp are all applied to the Godwit.

When the young birds reach us in their first flight, direct from their nesting haunts, they are speckled with brown and buff, and when they first arrive they are of a most confiding nature, but this wears off very soon. On some parts of the coast they are very local, and few in number; but where sand-bars are of great extent, and mile after mile of very dangerous flats are left nearly dry at ebb tide, there you may look for and see Godwits.

As to circumventing them, well, that is quite a different matter. When driven off the bar and flats they go to the rough pasture fields and keep a lookout there. But not for all the Godwits that visit our shores would I go where I have been for them, and without getting one. Others can tell the same tale; I am not alone in that boat. 
The Black-tailed Godwit is, comparatively speaking, rare. Why it has been named Black-tailed I do not know, for it has as much white as black about it.

The little coot-footed swimmers known by the name of the Grey Phalaropes are feathered wonders, being found far out at sea, numbers of them busily engaged on masses of floating sea-weeds, running nimbly over them, feeding or floating like corks, hundreds of miles from land. This nimble swimmer breeds far north, as far as it can get, and immense numbers visit us now and again; and so exhausted are these fowls at times, after continued storms, that they will permit themselves to be caught by the hand. In the year I866 a large flight appeared round the eastern and southern coasts, and in September I 870 hundreds were found near Brighton after a heavy south-east gale. They would not have come like that if they had not been forced by winds and waves to do so; the wonder is that the small innocent creatures werc able to reach our shores alive. They look like large grey-and-white moths hovering over the breakers-small swimmers for such wide waters. When sea-birds float in, battered to death by wind and water, there are heavy hearts in fishing quarters if boats are out. There is only one hope left, and that is that they may have made harbour somewhere.

In summer this little Coot-foot is very different, for the upper parts are dark brown edged with yellowish-red, the lower parts light red. The beautiful little bird has been found swimming and 
nodding its head in a farm-yard pond among the geese and ducks; but there it was shot, as a matter of course.

The Red-necked Phalarope is a small swimmer that breeds now in the northern districts of Scotland in very limited numbers. The insatiate greed of collectors, or those who collect for them, has in some places exterminated the innocents. We are well acquainted with the details of that business, a far from creditable one-mere bird slaughter in fact. The confiding innocence of the creature leads to its destruction. Northern regions are the real breeding-places of this Phalarope; but a few, as we have stated, nest in Scotland and the isles, leaving when the duties of incubation are over. For good reasons, not one of the few nesting sites now left will be mentioned by me. The females of the Grey and Red-necked Phalaropes are similar in colouring to the males, but they are larger and brighter coloured. The males do the principal part of the hatching-out business, and look after the young ones when hatched; thus reversing the general order of domestic bird life.

The Phalaropes may be called wandering migrants : they come and go as the winds and waves compel them. Some migrants can be looked for in their appointed seasons with some degree of certainty, but this can hardly be said of these two species. As might naturally be expected from the long flights they take, they are swift-winged birds and strong withal, as they well need be. 
The nest is formed of dry swamp grass, being about the size of a Tit-lark's, but deeper ; it contains four eggs, dull buff in ground-colour, marked with various-sized blotches of dark reddish-brown.

I have had the good fortune to watch those graceful birds the Black-and-white Avocets in a living state; very few illustrations give the idea of their dainty lightness. As to the bill, it looks as if two very slight pieces of whalebone had been curved upwards; but the bird uses it in the most adroit manner, never probing, but sweeping from side to side with it, collecting food out of the liquid slub and shifting sands. When on flight, they are most conspicuous birds.

The Avocet once nested in my own native marshes of North Kent, where the Thames and the Nedway meet the tide, on those treacherous flats which are cut into by channcls, cuts, dykes, shifting sands, and "gripes," a moist state of everlasting ooze and grey blight. The locality is not much altered in some places even now, for the simple reason that nothing can be done to alter it. And just over the water, as they call the Essex flats and shores, are the legendary sanctuaries for the fowl. Our own side was dotted with them, but these were only supposed to be a few discontented stragglers that had flighted from over there: full of mystery and full of fowl were those Essex flats. The fowlers on the Kentish flats would never even have dreamed of going just over the water, or the Essex fowlers of coming over to the Kentish shores. They were 
fiercely conservative as a class, and would have fought for the prescriptive rights of their own foreshores. "Cobblers, Awl-ducks, Scoopers, Yelpers, and Black-and-white Flighters were the names given to the Avocets.

The famous Romney Marsh was another favourite locality for them. What a lot of bird-lore have we treasured up from there! for the great flat was credited, and not without reason, as being the great sanctuary for all kinds of "strange furrin fowl." I remember when one of our fowlers brought a little Bittern and a Godwit from Essex, and they were unanimously reckoned up as "Romney Marsh flighters." If strange fowl were shot elsewhere, they were called "Frenchers," a very simple way of settling matters, but certainly not one that threw much light on the study of ornithology. However, it passed muster at that time.

All kinds of fowl, full-webbed, half-webbed, and hen-footed, have risen screaming, quacking, and whistling, disturbed by the tramp of great carthorses, teams of them, borrowed without leave for running a cargo of contraband over the marshes. Most accurate in their descriptions of the fowl were those old shore-shooters. Names were nothing, Latin ones especially, as we knew the local names; the men only had to reel off their experiences, and I for one listened most attentively. What they had not seen one day, very likely they would the next; in fact all my time, when no one else had a claim on it, was passed with the shooters and the local bird- 
preservers. And they also were shore-shooters; they never set a bird up in a false position or with unnatural surroundings.

None of them knew exactly what fowl did visit those places; but I am sure of one thing, birds that are considered very rare now were common then; sometimes the shots at rare birds are snap-shots, frequently missed; those of my readers who have made them will know why. A good shot frequently does not drop his bird. Shooting on the flats is not like shooting Partridges; but the duffer, if no one is near him, of course never misses, and he always brings fowl home-bought ones. I have found it a little awkward to be asked to admire a couple of stale Dun-birds as freshly-killed Teal.

The Black-winged Stilt is a long-legged bird that has been met with as a wandering migrant, so we may just notice it here. At one time, before the fens were drained, these Stilts visited them. Nothing could be more natural, for they could wade or swin in the shallower splashes to their hearts' content. Cultivation has done much, but when the fens and cars ${ }^{1}$ were drained, the whole fen fauna went with the water-animals, birds, fish, insects, and reptilesand the Stilts that very rarely come to us now can only be classed as long-legged wanderers.

The Greenshank is a shy bird that breeds on the lonely moors and mosses in the northern parts of Scotland. It is not common even there, in com-

I A pool used to be called a car. The word is still used locally for marsh. 
parison with other bircs of the same family. The nest is like that of the Lapwing, and the eggs, four in number, are greenish-buff in ground-colour, sprinkled all over with spots of dark brown, irregular in size, and blotches of light purple grey. The Greenshank, like most waders, perches at times: as the Heron is quite at home in the trees, why should not the small waders be so also? They certainly are now and again, but not to the extent that quiet fisher, the Heron, is. This bird will decoy a man or a dog away, if possible, if either comes where it is nesting. The nests of all this family of birds are hard to find, for any tussock or tuft of moor tangle growing on the thousands of detached hummocks will hide them. Besides this, if you know that a false step will sink you up to your waist in peat-bog, you are not able to give your undivided attention to the matter.

Shy and wary to a degree as this bird is, a female has allowed herself to be lifted off her eggs when these were just on the point of hatching off, without flying off. Sometimes the bird visits, for a short space, inland waters.

Some birds, so to speak, compel attention, and the Greenshank when met with is one of these; and such are the Yellowshanks and the clusky Redshanks, which we shall only name here, for they are not ordinary fowl, or at all events not likely to be met with by ordinary fowlers. The bird under notice sets you conjecturing what those desolate haunts of his in northern lands must be like. Desolate they 


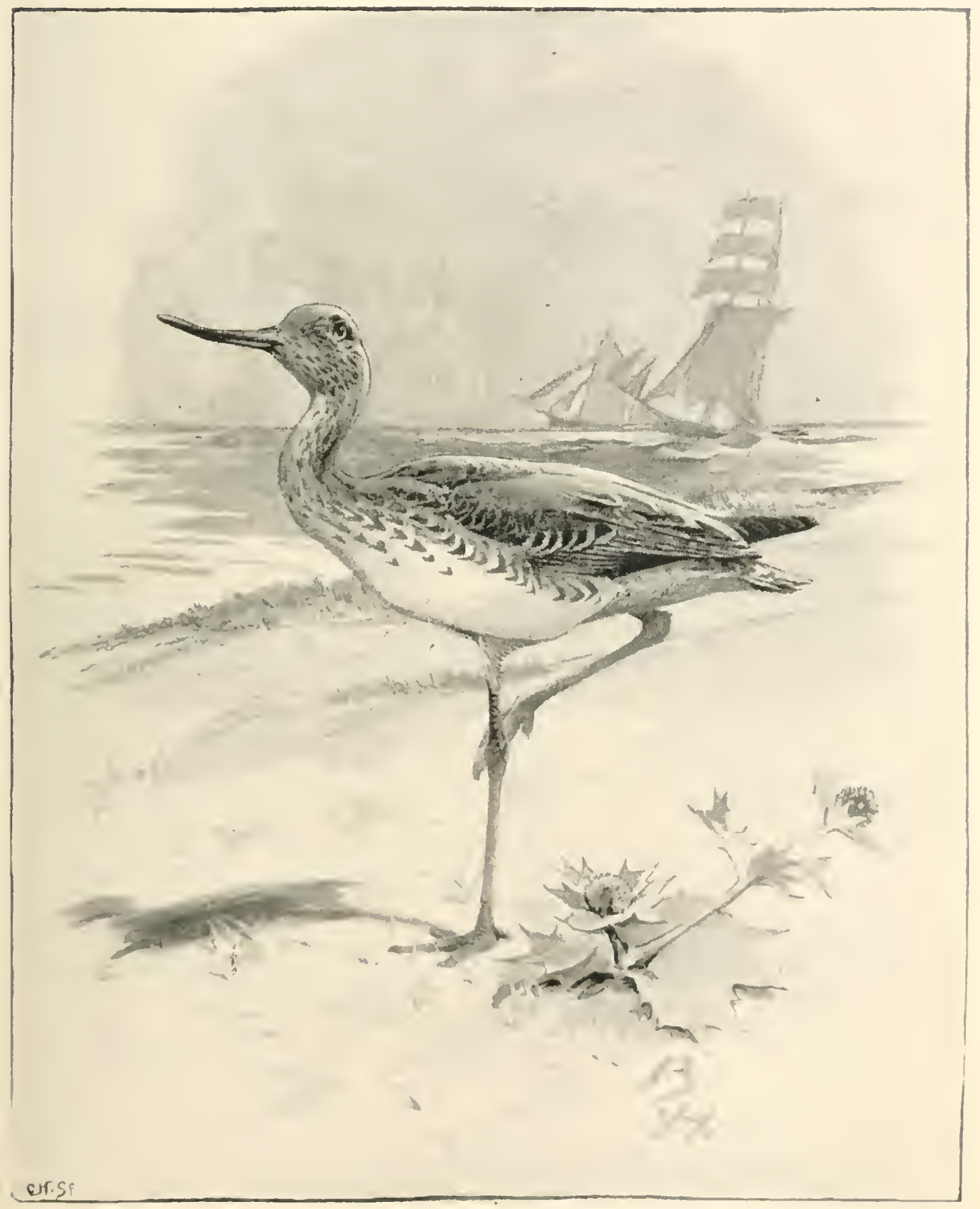

GKESSHANK. 

are so far as human life is concerned, but teeming in the short breeding season with bird life of many kinds.

It is not pleasant work exploring soft places in the season in order to look at the nesting arrangements of waders, for the insect life that is there in clouds, forming the principal part of their food, will bite you horribly, the midges worst of all; but such matters have to be endured somehow. There is one comfort, and that is, when one has made remarks of a forcible but vague nature about midges, no one has been within a mile or two, so they have gone unrecorded.

The Redshank is also called the Red-legged Horseman, Pool Snipe, Red-legged Snipe, Sandcock, Teuke, and Yelper, and these are only some of the names that the bird is known by. The nest, placed on a tuft or in a tussock, is only a slight hollow, lined with a few blades of swamp regetation; and the eggs, four in number, are pale greenishgrey in ground-colour, blotched and spotted with blackish-brown and reddish-brown. The difference in the two states of plumage is very slight; in the breeding season the dark parts are deeper in tone and more glossy, and the slender markings on the sides are more defined.

The Yelper he is called with us, and well does the bird deserve his name. Not that he is so particularly shy, for the very fact of his being seen and heard so frequently puts that on one side: but yelp) he does, and as a rule the bird yelps ont of grm-shot. 
If a few pairs are breeding you would never know, and in some cases never think it possible for them to be there; but they cannot keep quiet. Before you are near their nests they come to meet you, yelping their loudest. Then is the time to admire the sober beauty of the Redshank's plumage, as the birds shoot over and around you in strange flights. One curious position is when they hang poised, as it were, for a moment, with the wings bent down, and their red legs straight out under their tails, of course yelping their loudest.

The Redshanks, like the Lapwing, will visit a favourite breeding haunt even if serious alterations have taken place there-serious as regards the birds -if only a bit is left as it used to be. Only a short time back, on a strip of coarse torey marsh close to the walls of a large dockyard, near the mouth of a tidal river thronged with craft, the Redshanks nested in security through all the sights and sounds which were close to them. They were near their old feeding-grounds, and they could have bred there in perfect security; but no, they must come close up to the dockyard walls, for reasons known to themselves alone: the same motive, I suppose, that leads the Missel Thrush to leave the woods and build on some solitary tree on a gentleman's lawn.

That shore-shooters say hard things about this bird is not to be wondered at. Of course it would be simply ridiculous to imply that the birds have any motive for their yelping; it is, as they say, "the cussed yelper's natur." The bird, in fact, 
except when resting, is always in a state of restless activity; cven when he settles he is not able to stand still, for he bobs up and down all the time. No law is given to a Redshank, on the wing or on the ground he is pulled on, if within range.

In out-of-the-way fishing hamlets, at the end of wide creeks, some of them five miles long, with no houses between them and the tide, the water lapped the door-sills, and the fowl waited on the tide. From the very nature of the creeks and the salt flats on either side of them, food for the fowl was in unlimited quantities. I have started with a companion for better fowl, and when not five minutes' walk from our house we have put up a Yelper from the side of a rotten pile; he had been prospecting round. Then he has shot off zig-zagging from one side of the creek to the other, making a terrible row.

"Bad job that," says our companion; "he'll rouse some more."

He did so. The creck was, as they term it, "full o' fowl," for the tide had just ebbed; but the Yelpers had upset the lot, even the Ox-birds and Sanderlings were not to be got at. When we returned, after four hours' hard work, I had a couple of Sanderlings, and my companion a Woodcock Owt, that had got up out of the bents.

We owed this to the Velpers. Such things are not to be helped or provided for ; they are there, and you know you must put up with it. There is one consolation, what the guns miss getting at, the Aight- 
nets catch. They do dash into these at any rate; and you may see a grim smile on the face of the net-setter as he takes them out, remarking"There's a few more damned Yelpers settled."

The birds are fair eating; so that a catch of a dozen Redshanks is at least profitable. From a shooter's point of view, the bird is a sad nuisance to those who wander by flats, marshes, and lonely foreshores, carrying a gun more for compary than any other purpose; and a gun is very good company, never making a noise unless you wish it to do so. This restless, shrill-voiced bird is one of the greatest ornaments that frequent such places; he is so well shaped; in fact one may call him a well-set-up bird. When on the slub, no matter if it is hard or soft, he is a difficult bird to sight, whether he be following the receding tide, or nimbly getting his food on the flow-up; for the upper plumage falls in with the grey slub, and the light under-parts with the white stones and foam-bells scattered about on the slub.

He has vexed me enough in past times, but that is nothing; he has done the same with others, and his race will continue to do it all the time the tide flows up and down the creeks, slubs, and sand-flats. If I were asked to pick out a bird that should be a representative type of his family for alertness and dashing activity in all seasons and in all weathers, I should certainly pick out our old acquaintance the Redshank.

That dashing wanderer the Green Sandpiper is always on the move, coming and going with his 
peculiar whistle in the most erratic manner. You will not be able to look at a Green Sandpiper for many minutes, uncler the most favourable circumstances, in this country; at least such has been my experience. He comes and goes with his whistle, a kind of feathered express. Up to the present time this bird has not been found breeding in England, or rather the egrs have not been found. As this Sandpiper lays its eggs and hatches them out in the deserted nests of other birds, or in old dreys of squirrels, and as this is not at all known in a general way, it is not to be wondered at if he remains a hideling. Who would think of looking in the nest - deserted of course-of a Crow, a Wood Pigeon, Blackbird, Jay, or Thrush for the eggs or young of a dashing wader like this one? Yet so it is. A northern forester found this fact out, and he communicated his discovery to the naturalists of this country some time ago. As usual, previous to this important discovery-one that was very soon appropriated-full descriptions of the eggs and nests had been given, stating that the bircls built on the swamp grounds; of course descriptions written by those who had never seen them. From what I have seen of this bird, I suspect that it has been hatched out in the very wild parts of Surrey, Sussex, and Hampshire, where we have at times met with it, but none too often.

Those who have been used to the ways of waders from childhood, in their nesting season, can tell by certain movements, which it would be perfectly useless 
to try to explain, if they are likely to carry out incubation in certain places. I do not state that this bird has hatched out, but if certain signs are to be depended on, and I think they are, there is the more than bare probability that it has done this, unknown to all. A pair is before me as I write, exquisitely set up, and they were procured from one of the counties above-mentioned. They were shot, the male and female, resting on the bare bough of a low scrub fir that overhung the margin of a large shallow sandy pool, but not by myself.

The eggs, four in number, vary in their groundcolour, as most eggs do, from buff to olive, or buffishwhite spotted with dark red brown and pale grey brown. If any of my readers who are egg collectors should have the luck to find a clutch like this, they may be sure they have the eggs of the Green Sandpiper, so called from the greenish tone of the dark parts of its plumage. I think that the name of Wood Sandpiper ought to have been given to this bird instead of the one that it has. The Green Sandpiper is, as a very old acquaintance gone home long ago used to say, "the very activity" among the trees and bushes.

Snipes also perch at times. What is there to prevent their doing so? Their lissom toes cling to anything, as will those of a Jack-hern. A Moorhen can, when it thinks fit, stand on one leg and hold its food in the other, when it feeds like a parrot. I have scen it do this, and the toes are certainly long enough. Some writers have denied this fact, simply 
because they had never seen these things. Even the common Sky-lark has, in the most grave manner, been denied the power of perching; and, worst of all, the Sandpipers have not been credited with the powers of swimming and diving. As one of my acquaintances said, when he brought one to me warm from the water, to identify it, "Oh, Jerusalem! Can't they just!"

The IVood Sandpiper has bred in this country; but that is a record of the past, and we have only described it in the Appendix for the purpose of identification, if met with.

The nest of the Common Sandpiper is a slight one, placed under cover of some tuft of heather or wiry grass, not far from the edge of the water, or in a slight hollow by the side of a moss-covered stone. The eggs, four in number, are placed with the small ends together; they are very large for the size of the bird, glossy cream-coloured or reddish-white in ground-colour, covered with dots and spots of purple brown and purplish-grey.

This lively, neatly-formed bird arrives in England early in April. The angler looks on it with pleasure, for the bird frequents the reaches of rivers, and the margins of trout-streams, where pools and pebbly shallows alternate with mixed sand and pebbles along the margin of the stream, bordered with trees and meadow-land. There you will see the Sandpiper, Wect-weet, Fiddler, Willywicket, or Water-Junket.

Where you see the bird nimbly tripping, you will find fish in the stream or river, as the case 
may be. When the birds arrive they are in full breeding plumage, for the Sandpiper moults before coming to us, and it moults again after it has left England. It nests within a couple of miles from where I live, in Surrey, along the river-banks, stonelittered, covered with ferns and grasses to the very edge of the water, that runs in a most wayward fashion; here a narrow throat, running through some considerable wide beds of pebbles, shoots into a deep wide pool. From the pool the water ripples merrily over a shallow a few inches in depth; then for a space there is a run of fairly deep water, and after that a long run of shallows.

And here the Sandpiper is at home. He runs, flits up and down, now here now there, piping; now on some bough or stick, or bobbing along the margin of the water. A creature full of happy vitality, like the Ring Dotterel, the bird has the look of innocence about it. As his food consists of insects in mature and immature form, the sides of the streams provide food for it in abundance. The young are most nimble little creatures, running about directly they are hatched out; the down that covers them is greyish-brown above, with a brownish-black band down the back, the lower parts white. When they scurry out of their slight nest, as your footsteps go crunch crunch on the pebbles when you near them, you would walk through them without seeing one, if they would but keep still. But this they are not inclined to do, for their parents are anxious about them. Some little mites shoot over the pebbles 
into the water, where for a few seconds you see them carried along the edge by the rapid current like so many tiny Gulls: then they are gone. You need not waste time trying to find them, for you certainly will not do so; the parents have shot down the stream and are calling to them.

One nest found in a hollow of the river's bank, with four young ones, was gently lifted and placed in a cage, - this can be done if you know how to do it, - and the cage was placed where the nest had been taken from. A thin string was fixed on the door of the cage, leading some distance from it. The little creatures piped for "Mother" and she answered, running swiftly up to the cage containing her brood. The door was pulled a little way open, and in she went to her young ones; then the door was gently pulled to. This was effected in order that a drawing might be made from them, and directly that was finished the mother was let out, very loth to go, and the nest with the young in it was placed where it had been taken from. They were none the worse for their slight detention. I have never found very great difficulty in getting at creatures, if no one was in the vicinity except myself.

Other creatures can be seen where the Fiddler gocs through his light-hearted performances. Oh, the number of things some people miss secing because they are not able to kcep still! Restless beings, some of these, who will tell you they have a passionate love for nature, - a pet phrase just now, -yet who will in five minutes alarm all creatures 
within a mile of themselves, furred, finned, or feathered. They will just frighten a good trout to his hover, when he is gingerly feeding at the throat of a pool on the fat may-fly that comes floating down; not because he is hungry, but for the simple reason that he is unable to leave the luscious morsels alone, although he is full almost to his gullet.

The river-side is quiet here, very quiet; you hear only the faint rustle of young leaves and the ripple of the clear water; with the exception of a keeper who may chance to come along the narrow track by the river, you may not see a living soul all the day.

It is beyond the limits of an angler's endurance to see a good fish feeding in the season and not have a try for it, if he has his rod with him. But, as our old fishing friend Billy used to observe-_ "Some things is werry dubersome. You wants to turn things over a bit, and fish with your head."

On the feed again; just a lazy suck, barely making a ring. It is too much, he will be tried for anyhow. The walking-stick rod is put in trim; the finest gut trace and silk line, a cobweb-looking affair but strong, is arranged. Then the considering cap is put on. It is a warm May day, light vapour clouds drifting along at a snail's pace. It will never do to cast up stream to reach him; cobweb as it is, he will see it as he watches at the throat of the pool. So we observe a pair of Fiddlers on the opposite side of the river for a time. It runs narrow here; and one of the birds runs along the edge and picks up a may-fly from the water. This gives us an idea : 
we walk below the pool, well away, and quickly wash our hands. When they are dry, we search the sedges and capture two fat may-flies; a gentle nip with the thumb and fore-finger and they are dead. Then, very gently, we fix one on the hook, the head coming just over the shank; the other we fix the reverse way, the head only just covering the point of the hook. Then we are ready. Walking away from the water in a kind of half-circle, we drop on our hands and knees, and crawl to a little above the throat of that pool. Then we rest a bit and take our hat off, see that all is free, and with a gentle side-cast drop the two flies about six feet from where the fish lies. Down they float a little under water, as half-drowned flies do at times. It was too much for him to resist. There was a bit of a boil up, just a little, and we have him; that is, he is hooked, but not landed; a different thing altogether. We rise to our feet instantly, the top of our light rod being curved more than we care to see; but there is no help for it; the fact is he has deceived us, by his gentle rising, as to his weight, or rather size. Every moment we expect our line to go, or that there will be a smash of the very light top joint ; but no. Then up he shoots, a short thick stocky fish with rich Lrown back well spotted, and a belly the colour of gold. Once more he shoots up; then he bores for the bottom, all the pressure being put on that is compatible with safety. But it is no use, down he goes. Then, snick! there is the rod perfectly straight, and the line hanging limp by the side of it ; 
he has only been lip-hooked, has got on the bottom and rubbed it out. We make a few remarks in strict confidence to ourselves, and in the most deliberate manner, for there is not the least cause for hurry. We take our rod to pieces, wind our line on a large cork, and devote the rest of our time to the study of Sandpipers.

If not disturbed, the Fiddler will make itself contented on any small gudgeon stream. Things are strangely altered of late years. One stream that any boy could leap over I have seen all alive with the delicious little fish. The stream is there still, but the gudgeons are gone and so are the Sandpipers. This bird can swim and dive well. I have met with it in very different localities, on the tops of the hills, by the side of small rain-pools, by small dykes in water meadows, running about close to houses near the water and by the river-side.

Not that it is numerous, but a few nesting pairs, distributed at distances wide apart, by their ceaseless activity, running and flying up and down with their cheerful pipings, give life to very beautiful, but at the same time lonely places. So lonely and far away from man's direct influence are some of these, that the otter fishes in broad daylight, bringing his catch to bank and eating it there.

Wild creatures do not take the least notice of the rush of railway trains, they know no harm will come from them. The Sandpipers and otters live in peace close to where these are continually rushing up and down. 
THE BAR-TAILED GODWIT.

(Limosa lapponica.)

MALE.-The bill, flesh-coloured and dusky towards the end, is four inches long and slightly bent upwards; head and neck pale grey, with brown grey streaks. Back and scapulars grey, streaked with brown; hind-part of back white; tail feathers ash-coloured. A few of the outside feathers show some white splashes, but these are not bars; in fact unless the tail is widely spread they cannot be scen. Throat, breast, and other lower parts white; legs greyish-blue; the feet darker. Length, from bill to tail, fifteen inches. This is the plumage in which they are seen on the north-east coast in winter.

Ash-coloured" Godwits. - The intermediate changes are very varied. I have seen them all, and must confess that they are a little bit puzzling. Generally speaking, they are chestnut red in the summer and ash grey in winter. When on flight in winter plumage they look very like Whimbrels.

The females are larger than the males.

\section{THE BLACK-TAILED GODIVIT.}

\section{(Limosa belgiia.)}

MALE. - The bill is straight, orange yellow for a part of its length, the rest black; iris brown. Head and neck brownish-grey, streaked with grey brown; fore-part of back and scapulars brownishgrey, darker in the middle; those on the hind- 
part of the back darker. The upper tail coverts white, with black tips; tail white at base, the rest black, with white tips to the feathers; wing coverts greyish-brown, with paler margins; quills brownish-black tipped with white. A broad band of white crosses the wing; a streak over the eye. The breast, sides, belly, and under tail coverts white; legs and feet greyish-black. Length, sixteen inches. This is the winter plumage. In the red state, or summer plumage, most of the feathers are streaked and spotted with brownish-black.

The female resembles the male, but is larger.

THE GREY PHALAROPE.

(Pha?aropus fulicarius.)

MALE. - The bill black; iris dusky. Forehead and sides of head and neck pure white; occiput and a broad line down the back of the neck greyish-black. The back is a fine pale purple grey; wing coverts blackish, the quills the same; shafts of the quills and tips of the primary coverts white; middle tail feathers deep brown, margined with white; side feathers of tail ash grey. The lower parts of the plumage white; legs and feet light brown; the membranes grey, dark towards the end. Length, eight inches.

THE RED-NECKED PHALAROPE.

(Phalaropus hyperboreus.)

MaLe. - The bill black; iris dusky. Forehead, cheeks, and fore-neck white; upper part of head, 
a band below the eyes, and a narrow band along the hind-neck blackish-grey; upper parts greyishblack, streaked with white. Wing coverts and quills greyish-black; a white band shows on the wing. All the lower parts are white; legs and fect dark blue grey. Length, from bill to tail, seven inches. This is the winter plumage.

\section{THE BLACK-AND-WHITE AVOCET.}

(Recurivostra avocetta.)

NaLe.-The bill black, three inches long, and curved upwards; iris reddish-brown. Upper part of head and hind-neck, for half its length, black; some of the scapulars, the smaller wing coverts, and the primary quills and coverts black. The rest of the plimage is white; legs and fect greyishblue. The feet are what the marsh-men call "halfwebbed," that is, scmi-palmated. Length, from bill to tail, eighteen inches.

Fexalfe-Similar to the male in colouring.

THE BLACK-IVINGED STILT.

(Iimantopus candidus.)

M.u.e.-The bill black; iris crimson. Upper part of the head and nape greyish-black; fore-part of back, scapulars, and some of the secondaries, with their coverts, black glosses with green. Quills glossy greenish-black; tail dark grey; forehead, cheeks, throat, neck, midelle and hind parts, and 
lower parts white; on the breast tinged with rose colour; legs and feet vermilion. Length, from bill to tail, fourteen inches.

\section{THE GREENSHANK.}

(Totanus canescens.)

MALE.-The bill greenish-brown at base, black at the end; iris brown. Head, neck, back, scapulars, and wing coverts brownish-grey, the feathers on the upper parts edged with greyish-white; primary quills dusky brownish-grey; tail white, waved with brownish-grey. Throat and breast white, with some dusky markings on the sides; lower parts white; legs and feet grey green. Length, from bill to tail, fourteen inches.

This is as seen in winter, and will give a general idea of the colouring, although we have not entered into minute details. In summer, the fore-part of the back and scapulars black, the feathers margined with whitish colour; fore-neck and breast marked with oblong black spots.

Female.-Similar in colour to the male.

\section{THE REDSHANK.}

\section{(Totanus calidris.)}

MaLE.-The bill brownish-black, the basal half yellowish-red; iris brown. Upper part of head and hind-part and sides of neck dull light brownish-grey; fore-part of back, scapulars, and inner 
secondaries glossy greyish-brown; wing coverts margined with dusky spots, the interspaces grey: the rest of the back pure white. The tail and its upper coverts white, barred with greyish-black; primaries blackish-brown, the inner fine white towards the end, barred and dotted with dusky colour ; secondaries black at the base, the rest white. Throat whitish; sicles of neck and breast pale grey, each feather with a slender dark streak; the rest of lower parts white. Legs and feet orange red. Length, from bill to tail, eleven inches.

Fenale--Same in colouring as the male. In flight the white on the back and on the wings shows up boldly.

\section{THE GREEN SANDPIPER.}

(Totanus ochropus.)

MALE. - The bill dusky, redclish below ; iris dusky. Upper part of head and hind-neck brownish-grey; back, scapulars, and inner secondaries greenishbrown, with whitish margins and clusky spots: rump feathers white towards the end; tail coverts white, barred at the base. A broad white band over the eye; throat greyish-white; cheeks and foreneck the same, tinged with brown and streaked with dusky colour. All the lower parts of the body pure white; tail feathers white, barred with blackishbrown; legs and feet greyish-blue, with a tinge of green. Length, from bill to tail, ten inches.

Femane-Similar in colouring to the male, but slightly larger. 
THE IVOOD SANDPIPER.

(Totanus glareola.)

MaLe.-The bill dusky, tinged at the base with green; iris dusky. Upper part of head greyishbrown, the feathers edged with greyish-white; a broad streak of white from the bill over the eye. Neck all round greyish-white, streaked with brown; back, scapulars, and inner secondaries dark brown, glossed with purple, the feathers edged with white and black spots, the white spots being larger than those of the Green Sandpiper. The quills, primary and secondary coverts, also smaller coverts, blackishbrown ; throat greyish-white; breast and lower parts white. Hind-part of rump and upper tail coverts white; the tail coverts marked along the shafts with brown; tail white, barred with dusky colour; legs and feet greenish-grey. Length, from bill to tail, nine inches.

\section{THE COMMON SANDPIPER.}

(Totanus hypoleucus.)

MaLe.-The bill dusky above, brownish-grey beneath ; iris brown. Upper part of head and hindneck brownish-grey; a faint whitish line passes over the eye; upper parts glossy greenish-brown, banded and waved with dark brown; some feathers on the edge of the wing, the tips of the primary and secondary coverts, white; a bar of same colour crosses the wing. Sides and fore-part of neck light 
brownish-grey, streaked with dusky colour; throat, breast, sides, belly, and lower tail coverts white; side tail feathers white, barred with dusky colour; the rest darker; legs and feet greyish-green. Length, from bill to tail, eight and a half inches. FEMLLE.-Similar to the male. 


\section{CHAPTER VIII \\ WOODCOCK AND SNIPE}

THE nest of the Woodcock is made in some dry, quiet part of the wood or cover where dead leaves cover the ground, and trailing brambles are fairly in abundance, mixed with rough tussocks of torey grass and dead twigs and branches. It is lined with deacl grass and leaves. The eggs, four in number, vary in ground-colour from olive to dull brownish-buff, and are thickly blotched and spotted with dark brown and pale brown, with markings of purple grey. Let me give one picture of a sitting Woodcock from the life. At the bottom of a moor stone, shaded over by trailing brambles and tufts of heather, the stone itself being covered with lichens grey and brown, a litter of dead leaves and dry grass has gathered, as if the wind sweeping through the branches of the firs had brought them there to rest. At the base of the stone dead twigs are scattered about, some brown, where the bark has peeled off them show light yellow; some where the minute fungi have settled on them are grey; in fact there is a kind of network of clry twigs, 98 
brown, grey, and dingy buff, that look as if they had been blown on the stone and then slipped off, half hiding the dry grass and leaves at the bottom. One should never pass over such trifles; we see as we look closely some arrangement about it. Something glitters, then we have it all, a perfect picture. For there sits a Woodcock, hovered on her nest, her long bill half hicklen in the breast feathers, the tip just touching the outside edge of the nest. We can make out the upper part of her and that is all, so closely do the mottlings of her plumage fall in with the bits of stuff round about her.

But it is her full glistening eye that we can see distinctly; that, we know; is watching us as we stand, hardly venturing to breathe fully. She can only see part of us, and that is the worst part, head and eyes. The strain is more than we can put up with. Nothing is so tiring as to stand perfectly still in a strained position. But as we move, crack goes a dead stick underfoot. Flick-flick-flick! she is up and off, twisting through the twigs and branches in a wonderful manner. She had just begun to sit; we do not take the bird's eggs, we are only too pleased to have had the luck to see it. If the eggs had been hatched out we should have seen the usual shifts to draw our attention from the chicks. She would have fussed about, drooped her wings, and spread out her tail, holding it up like a fan, showing the silvery-white tips of the under tail feathers.

Woodcocks brced fairly well in our soutliem 
counties, particularly so round about my own home. and they nest early. I have known the chicks out when snow was on the hills. So closely does their down fall in with the mother's plumage, and so closely do they nestle to her, that if they do not pipe you would not know that they were about her. Hills that were bare at one time, that is, comparatively so, are now covered with trees, principally firs. As the water drains from the hills to the moist land at the foot of them, they are dry and the firs make them warm; you would not feel a gale in a fir wood. There is also a short undergrowth of heather, whortle-bushes, rough grass, ferns, and creeping brambles,-stone brambles,- - not thick and matted, but in open order, stuff that you can easily walk through. In such places as these the Woodcocks nest; some of their old haunts are gone I know, but they have found others suited to them. It is perfectly useless asking any velveteencoated guardian of the covers whether Woodcocks breed there; he will tell you in mournful tones that he "ain't sin one on 'em about for a year or more"; also he will give you the most minute details about who it was that shot that last solitary bird. At the same time there may be three or four sitting birds in one cover, and the man knows it.

After listening to this sort of thing once, I told a gamekeeper in the most emphatic words at command, that I knew some were nesting close to us. With various allusions to his Satanic Majesty, and other individuals of high degree and places of 
uncertain locality, he asked me how I knew that. I soon explained, and it ended in my going through that cover with him; after which we parted with mutual satisfaction, in fact I was invited to come again.

These birds vary very much in size and in plumage, males as well as females; so does the bill, both in length and in thickness. It is not the least use looking at the bill of a stuffed Woodcock; that will give you but a faint idea of the exquisite arrangement of encased nerves. The bird does not see its food as a rule; his bill probes for it, and the sensitive tip discovers what he needs. If you wish to see and examine it, you must do so after it has dropped to the shot, or better still, look at a tame Woodcock, for this beautifully mottled and pencilled creature is frequently domesticated. One man would have quite enough to do to provide worms to satisfy a couple of birds. The gentle creature has a fine appetite and a good digestion; after getting down a cupful of worms, it will look at you in the most gentle manner with its large dark eyes, asking for more. This is the reason why they are not seen in a domesticated state very often; you have to dig so hard for them at times to little purpose. Some of my pets have cost me as much as a small family of chiliren would.

That the Woodcocks were numerous up to recent times in one vicinity our readers may imagine, for every little round-frocked leather-gaitered lad living near their haunts "tealed" for them, springed in 
fact. The youngsters, boys and girls, were, as their parents called them, "reg'lar dabsters" at it. All the moist runs on that large waste were covered with little gates, having gaps in the centre for the horse-hair noose. Each one knew his or her teals, and if theirs were empty and their neighbours had caught, they left them there for their neighbours to take out. The folks were simple and honest, the unwritten laws of the forest were never broken, for good reasons. Very great prejudice exists in certain localities regarding the Scolopacida, the family of birds that the Woodcock stands at the head of.

"They gits their living out o' the bogs, sucks it out on 'em; and they ain't a-goin' down our gizzards, not if they knows it; other folks may get ' $\mathrm{cm}$ down if they like:" meaning that nothing would persuade them to eat such unclean feeders. This notion no doubt proceeds from the birds not lifting up their heads to swallow what they probe for. At the same time they will partake of a duck or a couple that they have just caught up and killed as they were dabbling and spattering in a dirty drain, which is by no means so clean as a moor bog or runnel. It is the same with fish. "Don't like the look on 'em, an' shan't eat 'em," although these may have been brook fish that were in question; yet they would put themselves to no small trouble to capture eels.

But the money that the cocks brought them in the season got the children shoes, and a few clothes 
when they were most needed. I have known them to hang covered with a whitc hoar frost, where the cocks have been springed at the time that kind of frost was about. Now and then some unprincipled prowler would take a bird or a couple from some of the "teals," unobserved as he thought. but he would not get away with them. Deserted as that wild moor might appear, at that time tealers were there from sunset to morning. Some one was hid up in a fern hover, on the watch, not for thieves, but to take the birds out of the springes and to re-set them.

One of that kind who are slightly hazy as to other people's birds has pocketed a couple and is marching off, as he thinks; but he is mistaken, for a muffled figure rises from his dry fern-brake lair and stands in front of the thief with the simple words - "Hand them 'ere birds over!" There is no dispute possible; in fact if there is the least hesitation, a tearing, panting scuffle cnsues; the two are like a couple of dogs at work, and the better man wins. Yet you might be on the moor for two seasons without hearing of a case of this kind.

There is no accounting for taste; the Woodcock is not drawn when cooked, the trail, as the intestines are called, on toast is considered the best part of the bird. If those who eat it had seen the marks of the bird's probing where I have, I fancy they would decline "trail" with thanks. But game in any shape I do not care for, even when hung just right: I prefer the joint. 
It is an accepted idea that this bird only feeds by night, and to a certain extent this is true; but not altogether. If his haunt is in some retired spot, and it generally is so, and hollows are about, damp but not splashy, you may see him rapidly turning and sorting the dead leaves over in the day-time. If alarmed, the head is drawn in ; he listens for a second or two, then squats like a toad, but he is very wide-awake for all that. If you get a chance, it will be a snap-shot, for he sits close to a thornbush. Those who have had a cock twist up in a place such as I have mentioned know all about it far better than I can tell them. The cry of "Mark cock!" causes as much excitement now as it has ever done. Pheasants can go for a time; no one shoots, for fear another may have a better chance than himself. All eyes are on the bird as he clears the trees with his long bill pointing downwards, it may be to flight back to the place he was flushed from. Both barrels will be loaded, never fear, when that cry is heard. There are so many chances of missing a cock, and good ones too. "Missed him clean with the first," you will hear said frequently, "but dropped him clean with the second." Some have, of course, wasted powder and shot to no purpose. I should like to know the exact distance at which a Woodcock is considered to be out of range. At the distance I have seen some fired at, one would really imagine this was all the time the bird was in sight, and that distance was no object.

The plumage in summer is lighter than what it is 
in winter, and it varies more or less, not remarkably so unless in white or pied varieties, but quite enough to notice. In the matter of weight he varies remarkably at times. I have seen very fine cocks, what we should consider home-bred, well-fed birds, not flighters, and there was exactly the same difference between them and those known to be flighters from over the sea, as there is between the wild ducks bred in this country and those that come to us from other lands. I believe myself that those creatures that do not have to exert themselves much in order to get a living, because a good living is close to them, are as a rule larger than those who have to travel a long distance for it.

The Woodcock carries the young at times, when in danger, and also to moist feeding-grounds when too far away from the nest for the chicks to travel to them. This has been questioned, but the fact is now an established one.

It is not often that two Woodcocks are killed at one shot, but Chantrey, the famous sculptor, once did this. The birds that flight to us from over the sea pitch down anywhere for a short time-only for a few hours-quite tired out: if any one has the luck to see them drop, some good work can be done with straight powder. One man known to myself picked up as many as fifteen out of a field of turnips. He missed some, but the number I have mentioned fell to his gun in one afternoon. They must be waited on quickly, for clirectly they are a bit rested they are scattered far and wide. 
The bird visits the tide, at times particularly often, where there are woods on the rising grounds that tidal rivers pass through. This takes place in hard weather. When it is, as they say, "bitter hard," he flights to the tide and feeds on the slub when the tide is out. He will swallow shell-fish then; little creatures, very small at first, and soft. Those of my readers that have wandered about on the slubs-hard slub, not soft-will have seen any amount of these that could be crushed by the finger and thumb without much pressure. Directly a change comes for the better, he is off again. So partial to the holly for shelter is this bird, that a holly-bush and a Woodcock go together. When out shooting, the men always tap with their beatingsticks any holly that they come near, and in many cases to some purpose.

The Great Snipe can only be considered as a very irregular visitor from its northern home. It differs from our common bird when flushed, for it rises in silence, spreads its tail like a fan, and flies rather heavily, without any erratic twistings such as our well-known Snipe has.

A northern sportsman first described the habits of this bird in the nesting season. They are far more like those of the Ruff than those of our Common Snipe. Recent investigations have found some Woodcock traits about them, very like tilting. The places where it has been flushed from and shot in this country, in many instances, have been where a cock might have been expected. I should fancy that 
insect life in immature stages formed a considerable portion of its food, for great quantities of it are near the surface, easily probed for in spongy, moist ground, not swampy. My first introduction, when a child, to the Snipe family was through a Great Snipe, for my father shot one many years ago. It was supposed to be a very large specimen of the common bird, very finely marked. My father was very interested in the matter, for although a thorough sportsman, so far as fowling went, he had never shot one so large before. As he could draw and paint, he made a very careful study of the bird in crayons-French chalks they were called at that time-and hung it up in one of the workshops. And there it hung unframed, just as he nailed it up, for more than forty years. If the place has not been pulled down, for all I know that Great Snipe, hanging up by a string tied to one leg, may be there now. No doubt more of these birds have been shot than have ever been recorded. With the general run of shooters a Snipe was a Snipe, and the heavier the bird the more he fetched when sold. As my father only shot for sport pure and simple, and like his eldest son had a slight taste for natural life, that crayon portrait was the result. If he had lived long enough to read some of his son's writings he would have been a firm believer in hereditary transmissions.

The nest of the Common Snipe is a slight hollow lined with sedge, bits of heather or grass, as the case may be. The eggrs, four in number generally, 
sometimes three, are greyish-yellow in groundcolour, with a tinge of blue; spotted and patched with dark brown and brownish-grey; but they vary in size and colour. Sometimes the Snipe, when sitting, will allow a chance foot to come very close, almost to touch the edge of the nest, before she springs.

The young are pretty little fellows, covered at first with down of a reddish-brown colour spotted with darker brown, and white on the head and upper parts. They leave the nest after being hatched out, and follow their mother in search of food. If danger threatens they squat, and the mother does the usual broken wing and leg business. Some years ago, before Aldershot was what it is now, numbers of Snipe bred close to it; for at that time you could find enough bog there to satisfy them. Some is left there now; it has not been quite improved away. It was not the least trouble to watch their most interesting aerial manœuvres, for they were humming and bleating in all directions over the bogs-bogs that you dare not venture on even with a long broad plank: the experiment was tried by one that would not be deterred by trifles, but the plank went under the floating bog when waiked on. So the Snipe had their humming all to themselves at that place.

At that time they were in numbers there, but we could find quite enough to answer our purpose nearer home. One spot is left where they can be found even now. It is a dangerous part for a 
stranger to hunt over; he would stand a good chance of being bog-smothered. I was there recently, probing round the edge of it, but I could not get on it, not even on the tussock humps and moss-cushions, for they were floating, and directly you placed your foot on one it would topple over.

The sun is sinking; not "low down yet, but low enough to make that long strip of quaking bog, covered only with mosses, rushes, and cotton grass, look like a glorious carpet, a mile in length, and fifty yards in width at its narrowest part. The flaming marsh-marigolds do not grow here, for this is only bog. The wooded hills on either side are in shadow, but the light falls on that quake and rests there. Up from the mosses springs a Snipe with "t'sick, t'sick, t'sick!" into the calm, golden-tinted sky of a soft May cvening. Up he shoots, but he has altered his tune a bit, "zoo-ee, zoo-ee, zoo-ee-ee!" then he stops for a second in his upward flight. Down again he shoots, humming like a top. Then up he shoots again with his " t'sick, t'sick!" and his "zoo-ee, zoo-ee!" to shoot down again humming as before, zigzagging all over the place, at least all over that portion of the bog where his mate is sitting on her clutch of eggs. Much controversy as to how the sound is produced-I mean the hum-have we seen in papers devoted to natural history, by writers who certainly ought to have known better. But if you tell a certain class of very learned people the simple truth, they get cantankerous, and sling ink in all directions to prove that they know nothing 
about it. In ten minutes I could make a simple little affair that would make just such a noise as the Snipe does when he shoots down, so that if you did not know what it was you would fancy a Snipe was humming if you had heard one hum; and it would hum from the same cause that the bird hums. Little chubby-faced "whapstraws," as I have heard country children in all-round frock and gaiters called, could enlighten some people.

The Snipe is a very suspicious bird, one that can conceal itself in the most clever manner. The plumage enables it to do this with little trouble. If disturbed when feeding, it will run to some withered tuft and squat, drawing in its neck, and with its bill inclined to the ground; you might walk over it, if the bird would allow you, without seeing it. When Snipe are feeding in sedge patches that have been cut down, they assimilate with the various tones of colouring that the decayed sedge stumps show, ranging from brown of all shades, and from deep buffs to cream colour where they are bleached, so that it requires a lot of searching at a very short range to pick them out. I have sprung them from green meadows almost at my feet, yet never saw them squatting, although I was looking for them. Any depression where a cow or a horse has left its mark on the meadow will be enough to hide the Snipe.

No matter how many birds may be about, you will always flush them singly, not far apart, at times certainly only a yard or two. The nature of their 
food compels them to feed apart, for they do not get a worm or insect every time they probe, or, I should say, bore.

The Jack Snipe is a solitary species, and the smallest of his family in the country; it has never been found breeding here, in fact up to the present little is known about its breeding habits. The clapper little fellow will make himself contented in a very small space, and keeps himself in good order when his larger relatives are in poor case. Any tuft or clod that will hide a Lark will shelter him from observation; and when a place suits him he is hard to move. You may put him up a dozen times from a field, but back he comes and pitches again. When in first-rate order-and it is very seldom that he is not so-he will weigh two ounces. He is at first-rate bird for a poor shot. One of my friends shot at one for a week and never got him, and some of his acquaintances remarked satirically that "he was trying to sow his little medder with sparrer-shot."

In hard weather, when the snow is deep and frozen on the surface, the Snipe suffers terribly, and thousands of these birds die of starvation. In some places so wretchedly poor are the dead birds, mere skeletons in fact covered with feathers, that the Dun Crows will not notice them, nor the Gulls on the coast-lines. If, when things are desperate, a sudden change comes, - and it does come at times very suddenly,- those that have survived hard times begin to feed at once, for worms and other things come near the surface directly. 
The Snipe are voracious feeders in their way, so they soon get in first-rate order again. They visit the tide in numbers. Some nights we have gone down when it was dark, but clear-no moon-and have seen them shoot over the creek, "scape, skepskep-scaping" their loudest when they caught sight of us waiting for them on the saltings. Some stopped behind for us to look at; for the spaniel was with us to find them when they dropped. But more went on not touched. It is a little difficult to judge distances rightly at night.

The birds vary in size and colouring. One before me has the dark and light markings very rich and bright; some again when picked up have a velvety bloom on the plumage. It is a very game-looking bird, and a great favourite with shooters. Some will account for nine birds out of a dozen put up; others, very good shots at other fowl, will miss shot after shot; for they either shoot a little too soon or a little over. One I once knew that had missed several very fine chances was told with grim marsh-land humour to "get well in front of the lot and shoot with his eyes shut." Not long after this he was missed, and on looking round a solitary figure was seen making his way back to the hamlet, with a look of dejection in his very coat-tails. Vast numbers of Snipe are netted to supply the markets; they fetch a better price, and they look more enticing to the purchaser. They are only a couple of bites when cooked, and it is certainly preferable not to have one bite half 
lead. They are erratic in their goings and comings in certain places, for reasons that they only know.

A place that has been deserted for years as one of their haunts, has been returned to this year (1894) in considerable numbers. When alterations are going on, in buildings particularly, they flight it elsewhere; then when all is properly settled down they visit that haunt again —at least they have done so in this instance.

\section{THE WOODCOCK.}

\section{(Scolopax rusticola.)}

NALE. - The bill is flesh colour, with a tinge of bluish-grey, dusky at the end; iris dark brown. The upper part of the plumage is coloured in a very intricate manner; forehead grey; upper and hindpart of head blackish-brown, with three narrow bars of pale reddish-brown. Back marked with blackishbrown grey, chestnut red, and brownish-yellow; sides and fore-part of neck light yellowish-brown, changing on the belly to pale yellowish-grey, all with narrow bars of dusky brown. On the lower part of the side of the neck is a patch of blackishbrown; wing coverts chestnut red, barred with grey and dusky colour ; rump and upper tail coverts of a lighter red, barred with dusky colour. Primary quills and coverts brownish-black, barred on the outer web with pale red spots. Tail feathers brownish-black. batred on their margins with red, leaving a large round grey spot at the end; legs and feet flesh 

colour. Length, from bill to end of tail, fourtcen inches.

FeMale,--Larger, but similar in colour.

\section{THE GREAT SNIPE.}

(Gallinago major.)

MALE.-The bill is yellowish-brown at the base, dusky towards the end; the iris brown. Two lengthened blackish-brown bands are on the head, slightly marked with light red, separated by a narrow middle line of reddish-white; and on each side is a yellowish-white band. The chin is pale yellowishbrown, neck pale brown, each feather darker in the centre. Upper parts variegated with black and light red, with four lengthened yellowish-black feathers tipped with pale brown; larger coverts black, tipped with white. The secondaries are largely tipped with white, quills greyish-black, the shafts white ; tail brownish-black, banded with chestnut red and black; the outer feathers on each side white. Middle of breast and belly brownish-white barred with brown; sides waved with dusky and pale brown; legs and feet pale bluish-green Length, from bill to end of tail, twelve inches.

The female is similar to the male.

\section{IHE, COMMON SNIPE.}

(Gallinago calestis.)

MALE. - The bill greyish-blue at the base, dusky at the end, a part of the ridge flesh-coloured; iris 
brown. From the bill two broad, lengthened bands of black, slightly marked with pale red, divided by a narrow band of reddish-white. From the bill over each eye a band of reddish-white; the throat reddishwhite; neck all round variegated with dusky and reddish-white. The long feathers of the back and scapulars are black, marked with light red, margined externally with white, forming four lengthened bands on the back. On the hind-part of the back and rump the feathers are barred with dusky and light red; also the upper tail coverts. The tail is brownish-black towards the end, barred or spotted with reddish-white, with a narrow curved band of black; the tip light red. The smaller wing coverts are purplish-black, tipped with reddish-grey; quills greyish-black; the primaries slightly, and the secondaries largely, tipped with white. Middle of breast and belly white; the sides waved and barred ; legs and feet pale greenishblue. Length, from bill to end of tail, eleven inches.

The female is similar to the male.

\section{THE JACK SNIPE.}

\section{(Gallinago gallinula.)}

Male.-The bill is greyish-blue at base, dusky towards the end, part of the ridge flesh-coloured; iris dark brown. From the bill to nape is a brownishblack band, narrow at first, but gradually getting wider, the feathers marcrined with brownish-red. On each side, from the bill to the nape, is a broad band of reddish-white, partly divided by a clusky 
line. Throat reddish-white; neck variegated with dusky colour and reddish-white. The long feathers of the back and scapulars are deep glossy purplishblack, mottled with light red, broadly bordered externally with pale yellowish-red, internally with rich glossy green. There are four lengthened pale red bands on the back; from middle of back towards the hind-part of it purplish-black. The feathers narrowly tipped with greyish-white; upper tail coverts and rump dusky, mottled with light red and margined with deep buff. The tail feathers are dusky, waved with dull red and margined with light; the wings clusky, coverts and quills tipped with greyishwhite; the breast and belly white. Upper part of sides streaked with red and dusky; legs and feet pale greenish-blue. Length, from bill to end of tail, eight and a half inches. 


\section{CHAPTER IX}

TIIE COMMON IERON

Tue nest of the Common Heron is a large flat structurc composed of sticlis, lined with grass, wool, or other matcrials. It is built as a rule on high trees; in fact Herons build like Rooks, whole colonies of them, only the nests are on a much larger scale. The eggs, from three to five in number, are bright bluish-green; these the Jackelaws steal whenever the chance offers. The Heron builds at times on the ground, when no trecs are near.

Very few birds have had such grace of sanctuary cxtended to them as the fine bird inder notice. Royal laws were framed for his especial protection, or we might say for the personal pleasure of those for whom he provided noble sport, that of hawking. Before fowling-pieces were known, trained falcons were used, not only for sport, but in order to supply game for the table. The Heron in those clays was a game bird of the highest rank, and a cast of white Gyr-Falcons was considered a noble present for any reigning monarch. Those who have only seen this long-legged, long-billed fisher seclately flapping 
along either to or from his fishing quarters, would be astonished if they saw the bird's full powers of flight brought into play. I have seen him ring up until he looked no larger than a Rook.

In olden times Gyr-Falcons were used for flying at the larger fowl. For this reason : they were then, as they are at the present time, the most powerful and determined birds of the whole family ; deadly footers, which means that when they strike they either kill their quarry or terribly disable it. As provender for the table as well as sport was a consideration, the Gyrs answered the purpose they were used for admirably.

But the Heron requires a lot of killing; and not only that, he is a brave bird, fighting to the last, all the time there is life in him; I am well acquainted with that forcible fact. I will give you one sketch of Heron-hawking, not of the past but of recent times, for the grand sport has been carried on within a few miles of us. Falconry has never really died out in this country, it has always been practised by a few gentlemen at various times, in places suitable for it. We need not state that open country is imperatively necessary for the sport.

Here he comes, with measured beats of his broad wings, which send him through the air at far greater speed than they appear to do. He is going home with his crop full of fish. All at once his keen eyes see a group of men below him, some on horseback and some on foot. He swerves in his flight, but it is too late for him now. A cast of falcons are hooded off with a whoop!-grand Peregrines, "Juno" 



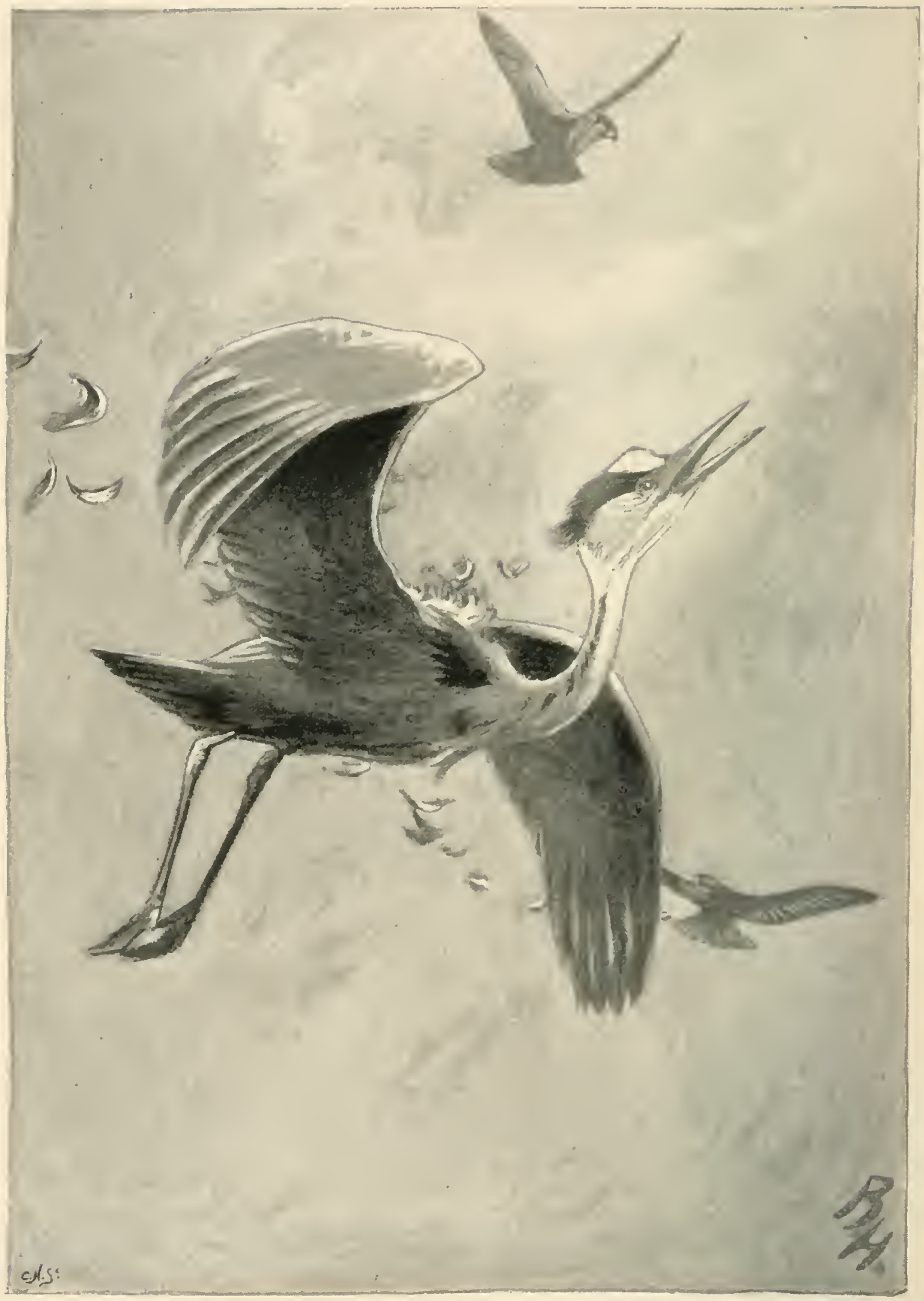

HERON AXD FA.CONS. 
and "Empress." He sees them, out he throws his fish, and at once begins to ring up; and the hawks do the same, sweeping round in great circles to get above him. To those who had never seen a flight before they would appear at times to be flying from their quarry. One more ring round and they are above him now. One shuts her wings and drives at him like a bolt from a cross-bow, but the Heron makes a shift and she misses him, shooting hundreds of feet below her quarry. Recovering herself she rings up again just as her companion stoops, hitting the Heron hard, and causing a small cloud of feathers to stream away from him. Now the one that missed her stroke is above him again; down she comes and binds to him, and her mate does the same. This is the time to run and ride, for the birds are slowly coming to the ground, buoyed up by their grand wings. Down they come. Directly the Heron touches the ground, the hawks let go of him to bind to him again instantly, for they are old birds that have gained experience. But the Heron is in one of the falconer's hands, his fish-spear of a bill secured from mischief, and the hawks made into, taken up, and hooded. It has been a rare good flight. The falconer places the Heron between his knees, so that it is not able to strike him, pulls out the two long crest feathers as trophies, fixes a mark on one of the bird's legs so that it may be known if captured again, and lets him go, slightly bewildered, but not much the worse for it all. 
It is when the Heron is on the ground that he uses his bill if he has the chance to do it; and this with fatal effect at times. The accounts that have been given of his turning his bill up when in the air, bayonet fashion, for the Falcon to impale on, are ridiculous fables.

They do not kill Herons now when hawking, for this reason-heronries are scarce, few and far between: if they killed them when captured, they would very soon have none to fly at. As it is, they are only got at under favourable circumstances, good trained falcons being rather costly creatures; if one is killed by a stroke from a Heron there is a direct monetary loss, quite putting on one side the regret of losing a dashing and very intelligent companion.

A bird of versatile ability is our Heron, quite at home in the trees, where he glides over the limbs and branches like a grey shadow; a very favourite perch of his as a look-out station is the top of some high fir, where he perches as securely as a Starling. I have seen him take the water like a duck. It does not matter to him where he is ; in the trees, in the water, or stalking along the edge of it, out in the middle of a field-not the side of it - or by the tide, he is equally at home.

$\mathrm{He}$ has been credited with killing unlimited quantities of fish. This is not just : small deer that can well be spared form part of his food. Other creatures live in or by the water besides fish, such as water-voles, water-shrews, frogs, and small aquatic birds, and these form part of his food supply. In 
some places known to myself protection has been given him, even where trout-streams run through the meadows, close to the woods that he frequents. If people think it is a fish he gets every time he makes a stroke, they will be deceived. I have known trout-streams utterly ruined as fishing streams, but not by the Herons. It was caused by the latest scientific improvements in so-called fish culture. IVe find him now when we look for him, in the same places that ancient members of his family frequented, when Falcons alone were used for his capture. These are the meres and lakes, reedfringed, and the wooded hills that rise above them; also the ruins of religious houses that the falconers of past days frequently visited from the manors below, with Herons, Bitterns, and Duclis for the good sisters' tables when Lent was over. Fish they had in abundance from the meres, lakes, and streams round about them, and from the rivers close by. There is abundance there now, although the Herons do throw the shadow of their broad wings on the waters as they fly over.

Swans, ducks, and eels will do more mischicf in spawning time by gorging on the spawn up to their very gullets than all the Herons in England would do in fair fishing. The bird can only wade so far ; small fish frequent shallow water, and bushels of some sorts could come out of some waters and the streams would be all the better for it. Any amount of fish is poached at times, but the Herons are not the poachers. 
The handsome Purple Heron (Ardea purpurea) and the Night Heron (Nycticorax griseus) have been shot in this country, but they can only be considered as rare visitors, that do not come within the scope of a work of this kind, which is written to give the general public an idea of the birds described in their haunts and general surroundings.

\section{THE COMMON HERON.}

\section{(Ardea cinerea.)}

MALE. - The bill is yellow; the ridge of the upper mandible brown towards the end; iris yellow; fore and lipper parts of the head greyish-white. From the eyes to the occiput the feathers are glossy blue black; general tone of neck whitish, tinged with reddish-purple, passing into purplish-grey below. A line of oblong black spots on a white ground runs down the fore-part of the neck; the upper parts are bluish-grey; the pointed scapular feathers bluish-white; quills a deep blue-black, tinged with ash grey, the secondaries shading into that colour; the edges of wings white. From the shoulders a broad band of bluish-black feathers, on fore-part of breast white, spotted with black; sides ash grey; tail ash-grey, darker towards the end. The bare space between the bill and the eye is green; legs and feet are olive-green, touched with yellow. Length, from bill to tail, thirty-nine inches.

The female is similar to the male, but her crest is shorter. 


\section{CHAPTER X}

THE COMMON AND THE LITTLE BITTERN

The nest of the Common Bittern is formed of sedges, twigs, and other coarse aquatic tangle, placed on some tussock, or a lot of matted vegetation caused by the reed-flags, docks, and other plants decaying and dropping. It contains as a rule from four to five eggs, of a light olive colour. As this bird only frequents the most lonely and desolate places, the nest, even where they bred in some of the eastern counties, and in one place very close to London, was very seldom met with by those who searched for it. The marsh and fen-dwellers found them, and the birds as well; Bitterns at half-a-guinea were worth looking for. They fetched this for the table at one time: a friend of mine gave a guinea for one in full breeding plumage, a fine male bird. He hesitated over the price for a moment, but was told he could take it or leave it, as they could easily sell it at that price. As he really wanted one he paid that for it, though quite recently a man I know bought a fine fellow for five shillings. The last authentic eggs, so far as I can learn, were taken at Upton Car, near Acle in Norfolk. 
The rage for reclaiming waste lands, and steampower being applied for draining, have given the Bittern notice to quit; he has taken the hint and gone. These birds would breed here again if folks would let them, but the high prices paid for them living or dead prevents it. The birds that do visit us generally arrive with easterly winds from the coast of Holland.

Bumble, Miredrum, Bitter-bum, Bog-bumper, and Butter-bump-the bogle of Tennyson's northern farmer-by all these names and a few more is the Bittern called, according to localities.

In our native marshes they called them "yaller French Herns"; some who affected natural history a little called them Bittern Herns. They noticed most of them about, the old marsh-folks have told me, "times and often when we fit (fought) with old Boney an' his frog-eatin' Frenchers!" What this had to do with the bird's appearing in unusual numbers I have never found out. Our folks certainly "fit," for plenty of good old muskets were to be found on the flats; I used one of them when I was there; ball or shot they would carry equally well, and they bore any amount of rough wear and tear. I have used fine fowling-pieces in my time. but it was a musket that I knocked about with when I splashed over the flats with that prince of dykeleapers, my friend Baulk. He knew more about "yaller Herns"- "Jipes" as he called them-than any man on our marshes, the "lookers" included. The marsh-men of the old type that I spring from are 
very conservative people, not much given to talking; but very devils for action, deliberate as they appeared to be. If they had got anything to say, out it came, offend or please, no matter who was in front of them. If angered, no sooner the word than the blow, and very often the blow came first. They kept their own company.

When I was a lad only those who lived there knew what the marshes contained in the way of fur and feather, or what passed over them at times between the night and morning; and at times in broad daylight, where the spot was very lonely. Some of our marsh-lands seemed right out of the world, or on the outside edge of it.

The marsh-folk did not come into the towns unless they had urgent business there, either to purchase some necessary article, or to sell some fowl, fish, or mushrooms. They came in and went out in the most quict fashion, and very rarely did they leave without purchasing a considerable amount of laudanum. Spirits they never bought in the towns; for reasons kept to themselves that was not necessary.

If I see a Bittern now, after all the ycars since I left their haunts, it sets me thinking; and once more I seem to be standing on the most treacherous parts of the flats, covered with splashes and pools, with a film on the surface of them, coloured with all the hues of the rainbow. The frrm part where we stand is rank to smell and bad to stiund on for any time. Reed-beds are all over the place; low reeds, 
for the water and ooze combined will not bring them to their full height here. In the heat of the day the place steams; when the sun gets low, heavy curtains of grey thick mist will float about, just the right height to let you breathe all the noxious vapours of that ague and fever-stricken district. No wonder that suffering as they did they should try to gret as much as they could from the marshes; they required it all and more. Something was always required in some way or other. Boats are not to be had for nothing, and they had to have one; a marsh-man without a boat is nowhere, for he wants to use it continually to get his fish and to get at his fowl when the night falls. The haunts of the Bittern are full of strange sounds, for other birds of a retiring nature frequent the spots that he prefers. Much has been written about the boom of the Bittern by those who never heard it, and never will. The bird has a weird cry of its own, but it is not a boom. The Snipe drums, or rather we might say hums, in the evening, and that sound has, I know, in more than one instance, been attributed to the Bittern by those who ought to have known better.

Some parts are not flooded at high tide by the salts, others are. Where the foul water has drained for generations of marsh-folls from the lands above to the bog below, reeking and bubbling, it causes the tangle to flourish with almost tropical luxuriance. Think of all this marsh vegetation growing and decaying--for who shall say how long?

Here the Bittern hides in the day-time, stirring 
himself when the Marsh Owls are on the hunt, when thousands on thousands of frogs make the whole place appear to tremble with their croakings. Then you hear squeaks, whistles, quacks, grunts, and strange spatterings, with "weet - weet - weets!" Herons call hoarsely as they rise; then all is very quiet for a time; bats are all over the place, adding their sharp grating squeaks to the general tune-up. Some Redshanks cross over, going to the slub noisy as usual: this appears to start the noise again, and with a few more strange additions. It was here that the friend I have mentioned would come to thresh one out, as he termed it, with his long ash leaping-pole. Hard as I have begged of him to let me help beat that large strip of tangle, he would never allow me to enter there; he said it was too risky for me; so it must have been bad indeed. I have thought, and still think, that the tangle of that foul marsh might have concealed other matters besicles a pair of Bitterns; but I knew better than to question him on that point. If he told me to stand still in one place, I did it.

The Bittern is a skulker; he will not move if he can help it. Those who got the birds were half afraid to handle them at times; not for fear of the bill or claws with which the bird fights so desperately, but the strange positions the creatures placed themselves in at times made them look uncanny. They would squat, and spread their wings on each side of them, with the neck, head, and bill held bolt upright, looking like a lump of dead flags with a broken 
stem sticking up; then when almost trodden on, up they would get and flap heavily away; and then they got it, as Baulk said.

One that was wounded drew itself up by some dead flags, and looked so like them that the shooter touched it before he knew what it was. Crammed as all marsh-men are with the lore and traditions of generations, it is not to be wondered at that at times they should be very much influenced by their surroundings. In their way they were influenced quite as much by what they saw and pondered on as are the Scottish Highlanders, and that is saying a great deal; it is, however, perfectly true. If I were to stand on the flats and hear what I have heard there at night, my blood would ingle again as much now as it did then; there is something electrical to a born son of the marshes in that cry and clang of fowl at night.

On the Essex side of the water it was, as they said, all fowl; one thing is certain, enormous quantities were captured there; and more Bitterns were found there; for, bad as some of our bogs were, they were worse on that side of the water. Our people knew nothing about the fowlers on the other side; they were "furriners" to us, although only a short distance over the water.

In spite of all inborn ideas, and their own peculiar temperament, they never funked at anything, and they never moved without their guns day or night; these were always loaded, because they did not know what they might fall in with above or below. 
I once heard Baulk say that his gun "would knock a hole through the clevil."

In its nesting habits the Little Bittern resembles its larger relative the Common Bittern. There is not the least reason to doubt that in past times this bird, like many more now rare waders, bred in this country; low wooded swamp tangles are its favourite haunts, and vast fens once existed, which were in certain parts such watery wildernesses that only the fen-dwellers could penetrate them. I have had the fowl-records from some of them. given by old people that once lived there when I was a young fellow; and all that they told me has proved to have been correct in the most minute details.

Bitterns are good climbers, the one under notice particularly so; the bird runs up and about the rushes and reeds with as much agility as the Bearded Tits that live and nest in the same moist tangles. The long, lissom toes of the Herons and Bitterns cling and hold to any object like twisted stone osier bands. All waders can use their supple organs of locomotion in a far more varied manner than they have yet been given credit for generally. Practical field naturalists have long known this. Some years back a Snipe was seen perchect on the top of a fir tree: this when spoken about was considered a fine bit of Munchausen ornithology; but he does perch at times, especially in the breeching season, like the Sandpiper: I should like to know what there is to prevent it. I had once in my possession a good 
drawing of a Little Bittern climbing up the trunk of a tree; this came with a few more things I possessed at that time direct from the Continent.

Where birds were concerned, I did not mind asking as many questions as those I thought knew about them would answer. My father was interested in bird life, but he did not encourage me in the matter, for reasons he kept to himself. He thought, no doubt, that the time would come when I should have to fight my way through the world single-handed, as indeed I have been forced to do. It was well that softness did not enter into one's early training.

\section{THE COMMION BITTERN.}

\section{(Botaurus stellaris.)}

MALE.-The bill greenish-yellow; ridge of upper mandible brown; bare spaces on the head greenishyellow; upper part of head and occiput purplishblack. General colour of plumage light reddishyellow, variegated with brown and black, with barred and waved markings on the sides, hind-neck, upper coverts, and part of back behind the scapulars. The quills are blackish-brown, with a tinge of greyishblue, barred with yellowish-red. The tail is lighter, and narrowly barred; on the fore-neck the markings are larger, more brown in tone, and of a lengthened character. The fore-part and middle of breast are streaked with brownish-black; the iris is light yellow; legs and feet greenish-brown; the back 
part of the legs yellogwish-green. Length, from bill to tail, thirty inches.

\section{TIE LITTLE BITTERN.}

\section{(Ardetta minuta.)}

MALE.-The bill yellow; the ridge and point of upper mandible dusky. Upper part of head, back scapulars, and tail glossy greenish-black; small coverts buffish, secondary coverts greyish-white, primary coverts black; quills black, glossed with green. The sides of the head and neck yellowishbrown; the rest light buff feathers, on front part of breast brownish-black edged with buff; iris bright yellow; legs and feet dull greenish-yellow. Length, from bill to tail, fourteen inches.

The female is similar to the male, but not so richly coloured. 


\section{CHAPTER XI}

THL WIITE SPOONBII.I.

That very interesting bird, the White Spoonbill, once nested in this country, establishing itself in the trees in the same mamner that the Herons do at the present diay. Sussex was one of the counties it nested in, and it now visits us occasionally. Although a rare visitor, it has been shot on the marshes which I know so well. When Spoonbills come, the Giulls persecute them terribly, driving the poor strangers all over the mul-flats. The late E. T'. Booth shot a female Spoonbill on Breydon mul-flats, near Yarmonth, in Nay $1 \$_{71}$, and a male of the same: species on the same flats in May 1873 . Both these hirds are in his matchless collection. In June 187,3 he shot a very ratre visitor, nothing less than a fine White Stork, on Rush Hills, ncar Potter Ifeigham, in Norfoll, where the White spoonbill also nested in past years. In some records of 1608 , these Spoonbills are mentioned as

Shovelardes" - white birds with spoon-shaped bills and capped (crested) crowns which buile in trees. Now this description is delinite enough to prove that the "Shovelatede" must be the Spoonbill, ats the Shoveller Duck does not answer to it. 
It secms very strange: that birels should mol, rase: visitors in the way they to. Jealousy in the matter of their food can hardly les the ciuse for such persecution, as theres is enough on bircyclon nats, when the tirke is out, to reed flocks of spoonlsills in ardelition to the birels which now feed there. I do not think it woukd be difficule to estatslish a colony of Sporonbills. Anel talking of this jealousy, I remember a Gannet which bad somehow grot inland pitching down on a large mill-ponel near me, and no sooner was he sctuler than the swans, ducks, coots, and moorhens made a regular rush for him. liut they did not have things all their own way, for the Giannet foumb well, and made some of their feathers ny before they succeceded in driving him off.

\section{THE WHITE SHOONBIIL.}

\section{(Inalalea lewentodia.)}

MA1:-The lill black, variegrated with ycllow or grey; a consideralde portion of the expanded patet of the upper mandible yellow; iris red. The throat, bare, yellow; crest feathers tinged with yellow, with the exception of a buff-coloured patch on the lower part of the neck and fore-part of the breast. The rest of the plumage pure: white, tinged at times with pink; legs and feet dusky. I, congth, from bill to tail, thisty-two inches.

Frimate - Similar to male, but the crest is smaller, and there is less buff on the becist. 


\section{CHAPTER XII}

THE RAIL FAMILY

WeLL concealed in the very depth of some tuft of aquatic vegetation, with a run to it, in and out, and so hidden by the tangle as to be most difficult for ordinary searchers to find, is the nest of the Water-rail. The eggs, which vary from six to eight in number, are of a cream ground, spotted thickly at the upper end with rusty red and faint grey spots, and at the smaller end finely and thinly spotted with the same colours. The yolk is a bright blood-red.

The form of this prince of skulkers-Skiddy-cock, Runner, Billcock, Skit Runner, Brook Runner, Velvet Runner (for he owns no fewer than all these local titles)-is most admirably suited for the life he leads, that of threading his way through tangled and matted swamp growth. In fact the bird might be called a living, feathered wedge, as where his bill and head will go, his body follows. When he is put up, or, as one might say, out of his haunts, the bird's flight is slow and awkward, with the legs dangling. I have seen him go at a great pace 
when necessity compelled him to do so; but reedbeds, sedges, and swamps are his abiding-places, and if his legs and feet can save him, the Waterrail will not use his wings unless forced to do so.

$\mathrm{He}$ is far more numerous in certain localities than most people imagine, and he is heard more often than he is seen. Very few would give him credit for the noises he sometimes makes, unless they had proved for themselves beyond any shadow of doubt that such sounds actually proceeded from him. He has claimed my attention considerably when near his haunts, as just before pairing-time he will, for some reason, show himself on the edge of the swamps quite openly, considering his confirmed habit of hiding himself at other times. All the rest of the year, if I have wished to see him, I have been forced to literally get into the swamps and wade very, very cautiously in evil-smelling water coming above the knecs. As you move in these swamps you stir the bottom up; and even the mud and the evil smell are not the worst part of it, for the horrible midges that infest the place are maddening in the tortures they inflict. The edges also of what are locally called "sword-blades" will cut like a knife if you incautiously catch hold of them. These "sword-blades" are long, green sedges, exactly the shape of a small sword-blade, and about the same length.

But, under some circumstances, the haunts of the Water-rail appear very beautiful. The sun is groing down behind great masses of clouds edged 
with lurid light. A thunder-storm has passed over without breaking, although passing near enough to leave behind it huge cloud-banks whose edges are lit by the setting sun. The surface of the mere is, as is usually the case when rain is near, a perfect mirror. The wooded hill, and the old farm in the hollow at the bottom, with the thin, blue woodsmoke curling through the trees above, and the long reed and flag-belts backed by the grey-leaved, stunted willows and alders, and the great docks and the rush-sheaves-all these are reflected in the water below perfectly. Such a picture as this may sometimes be seen before a storm, but more frequently after one has passed over, leaving all things in a state of perfect rest and quietness. On the surface of the mere float large patches of green and yellow weeds, and rush-stems spring up here and there, and the broad leaves of the water-lilies can also be seen just beyond the floating reed-patches. These almost hide a large alder-stem which has gone down in the water, for the simple reason that the bog mould gradually sank away from all its roots. One or two of its branches show just above the water, covered with grey moss, and that is all. The light comes from behind, so that my glasses will tell me what birds show on the open parts of the water just outside the reed-belt. A few ducks are spattering about; they are nesting somewhere on the tussocks that rise high and dry above the swamps, but they do not interest me much, I have seen them about before. 
Coots clank, and a Moorhen rises and goes spattering over the water, leaving a sparkling wake. A pair of Fern Owls (Eve-jars) flit from the moors above and hunt for some time to and fro like the Swallows; and the Bats flick at times the water with their leathern wings. But nothing more can I see here. If I had my rod I should try one or two of those holes beyond the reeds for perch. Large fish feed when all things are quiet; but as I have not got my rod with me, and happen moreover to be just now on the look-out for a Rail, I pass on to try another place before the light fails. There is no time to waste, for I have nine miles to tramp home after the sun has gone down, so I make for the mouth of the feeding stream which fills the mere. That part remains, or at least it still did the last time I was there, quite in its primitive state, - just as it must have been when the vesperbell rang out from the hills above over the waters of the mere,-a swamp floored with the decayed vegetation of centuries, the only narrow belt of such now left near the mere. And even this much is not likely to remain for long, for, unless I am very much mistaken, this swamp will soon be drained and improved away like the rest. But now it is a tangle of all the vegetation a southern county affords, in the rankest luxuriance; and I believe that if it were possible to get among it, rare butterflies could be found which are supposed to be almost extinct. I once put a Sivallow-tailed Butterlly up from the edge of the swamp, on firm 

ground, but failed to get it as it went into the tangle.

For about fifty yards there is a sullen narrow run of water which empties direct into the mere. Here there is not a sound, not even a rustle of the reeds, or a nod of a simple reed-tassel; not even the chiding of a Reed Wren, or the babbling chatter of a Sedge Warbler. But I do not give up hope of finding what I have come to look for; if a Rail is about at all I shall see him here. A water-vole runs out from the swamp along the edge of the water-at least by the movement I imagine it at first to be a vole; but I am deceived, for it enters the water, and then I discover through my glasses that it is a Water-rail which is swimming over that narrow bit. Slush! and the bird has gone out of sight. No dive that, for the water is too much disturbed-a pike has had him. These greedy creatures come up from the mere into the feeding stream that runs through places not yet explored, because it is impossible to get into them, to vary their fish diet with a little bit of fowl. As a rule, in most cases the accounts of fish are a little legendary, but not so in this instance; if I were asked I should say that their weight in this water had been under-rated. I have seen pike here up to twenty-two pounds in weight, while as to the trout that so much fuss has been made about, all to no purpose, some of them run in that same water from three to four pounds. If these are not heavy enough for common brook fish, some people must 
be hard to please. There the fish are, and the interesting fact is known not only to myself, but also to one or two friends still living. We once tried our best to range that particular piece of quake-belt, but failed completely.

It must not be supposed that these large fish are very often captured, even when known to hover in certain places, and when tried for by men who are and have been past-masters in all pertaining to fur, feather, or fin. The fish are very fastidious as to their food, for one thing, and also as to the exact spot where they have their home, and they wait for their prey to come to them. One of the largest trout that I knew was caught under two rough planks that carried over a stream in some water meadows; and the last pike that came under my notice, a fellow of twelve pounds weight, was caught in a bit of pure spring-water no larger than a duckpond, and close to a railway station; in fact the embankment formed one part of its boundary. Just where you least expect to meet with things, there you do meet with them. This is the rule, not the exception, in the things concerning wild life.

When the little black, downy chicks are out, both their parents have a most anxious time of it, for pike, trout, eels, and snakes are on the watch for them, as well as for the other young water-fowl, as they run over the water-lily and candock leaves. There is just a little tremor as the little chicks run over those floating leaves, and then the fierce fish below work their fins in eager expectancy, and they 
slip off the leaf into the water and down the guilet of a pike or a trout. Two or three will thus clisappear at a time, if they are huddled up together when the rush comes from below. I have seen the fish go through this kind of performance over and over again. Trout are as voracious as pike, only more dashing in their movements. As to the eels, they are very fine in the waters that have just been mentioned. They are silver-bellied, sharp-nosed eels, not the frog-mouthed ones, and they have a great weakness for young birds; the worst of it is, too, that they can leave the stream that runs through the quake, and travel through it to pick up any chicks that come in their way. In the season, one of the most deadly baits for an eel is a young bird of any kind, a young sparrow being particularly attractive.

A large trout is a very cautious customer. A friend of mine tried for one that had its hover in a hole formed by the wash of water at the base of a very old sluice wall. He had tried him all ways, so far as he knew, when I recommended a frog, and told him how to fix him without hooking, so that he should not be hurt in the least. My friend did so, letting him go by that hole until he got perfectly disgusted with his want of success. He released the frog and threw him into the water. Down went Froggie, striking out bravely until he got to the hole, and then his striking out came to an abrupt end, for that very same trout had him with a rush. The man never tried for that trout again. 
Where very large swamps exist, as in the fen districts, Nater-rails are abundant. In fact a trade in their eggs is carried on by the eggers of the fens, who will procure the eggs of any bird that breeds there, or, if necessary, the bird itself. I have little to say about this, for it is only the toll which has been taken from a period beyond record from the fens and marshes. No one but a fen or marshdweller could procure the birds' eggs, and these dwellers in the wilds are not numerous now, for do what they will their old haunts, or rather such as remain to them, will not keep them as they used to do. But the fen birds will only go with the fens; and one thing is very certain, Water-rails will not be exterminated, let the few remaining fen and marshdwellers do what they will.

When hard weather sets in, and the swamps and river tangles are frozen hard, then our little greyand-brown skulker comes to grief, for he can be threshed out from cover. I have known three or four Rails got in a very little bit of tangle, but that was in the winter-time.

The Spotted Crake is a migrant, although some of the birds will stay with us. Its habits are similar to those of the IVater-rail.

Baillon's Crakle visits us irregularly. From its small size and secluded habits it has no doubt escaped notice very frequently; as, even when seen for a moment, it might be easily mistaken for the young of some other water-bird, especially if seen in the evening. Su well are its skulking habits 
known, that in the marshes on the Continent small Crakes are called "Kill-dogs," from the difficulty in flushing them.

The Little Crake has not yet been found nesting in this country, but it may have done so, as many birds nest, get their young out, and then leave us without any human being knowing of their whereabouts and proceedings. This is as it should be, for if the nests of all the birds that visit us and breed in England were known, our poor feathered visitors would have a rough time of it, in spite of the Birds Protection Act. But the very nature of their haunts protect the two species of Crake that have been briefly noticed. The shyest of all shy creatures, all they aim at is concealment, and they carry out their purpose with perfect success.

I have been in, as well as on, very beautiful but dangerous quakes, where green oat-grasses, tasselled reeds, docks, sedges, marsh-marigolds, forget-menots, arrow-heads, and water-lilies, with great grass tussocks, spread in all directions. All was afloat below, as you found when you broke through, and the whole of this radiant display of wild-flowers was "cluttered up" by alders, willows, and sallows; some fallen, others ready to fall, and a lot of them growing vigorously. There was water all round and below you, as you made your way, not daring to take a step before you had probed for it. I saw as much as I could manage while I was there, but I am very sure that I did not see half the wealth of bird life which that swamp held. 
"I'm gone," my old friend said, and so he would have been if he had not clutched hold of a bough, and even then he was up to his breast in the quake. The pair of us were Crake-hunting.

The nest of the Corn Crake is formed in some slight hollow. It is a very simple affair, lined with a few grass-straws. The eggs, which number from eight to twelve, are greyish-yellow in ground-colour, dotted, patched, and blotched with brownish-red or umber, and light purplish-grey. The young birds are quaint-looking little things, covered with blackish down. Directly they are hatched they leave the nest and run about.

If you are walking through fields where the grass is growing long for hay, you may hear "crake, crake, crake-crake-crake." These sounds proceed from the Corn Crake, far better known as the Land-rail. In some districts it goes by the name of Daker-hen, and is also locally known as Land-hen. This bird is a migrant, being heard frequently, although very seldom scen, in the southern counties about the latter end of April. Its being so seldom seen may be owing to the luxuriant grass crops and other cover suitable to it. Although numbers are about in all directions, it is very rarely that one is shot or captured.

I have seen more Water-rails that had been shot than Land-rails. In my own immediate neighbourhood, the Corn Crake rarely reaches the hands of the bird-preserver. It has been stated that this bird can be drawn close up by imitating its cry, 
drawing a piece of hard wood over the teeth of a dressing-comb. Have those who made that statement ever tried such a plan, I wonder? If they have, and it has succeeded, all I can say is, that they must be far better performers with a comb, or rather I might say on one, than any one where I live.

The Corn Crake never makes use of its wings if it can possibly avoid doing so. Its flight is very deceiving, a sort of half-crippled wing-and-leg performance, but when well up-and birds of this family, the Rails and Crakes, mount high when they mean to travel-they go at a very great pace, like some other short-winged birds that are well known. To a great extent the Corn Crake is local in its choice of a nesting site; when once it has fixed on this, there it will remain.

One small meadow, surrounded by cottages which were filled with children, was laid down every year for hay, the owner getting enough off it to keep his donkey in the winter-time. Now such meadows are not supposed to be walked over, but the "crakecrake-crakes" -now here, now there-were a little too much for the rising generation of those cottagers. They quartered the meadow in all directions, but they never caught sight of a Corn Crake. When the grass was cut there, they were very anxious to help make the hay, at least so the youngsters declared; but in reality they wanted to get the young Corn Crakes, and, if possible, one or two of the old birds. They did see some of them certainly, 
but all they captured amongst them was one black little chick which they brought to me, to be turned down again directly.

When the hen is on the point of hatching out, she will allow the mowers to cut round her without moring. Sometimes the poor little birds get cut in two. It is impossible to avoid cloing this at times; even rabbits that squeal, listening to the swish of the scythe a little too long, share the same fate. As a bird for the table, the Corn Crake is highly prized. Eight couples were bagged in Sussex while partridge-shooting, out of a field of clover of about two acres. I have never heard of such numbers being procured at any time in Surrey. Why, where they are fairly numerous, these birds should only be procured one or two at a time, with wide intervals between, I do not know.

The Corn Crake can swim when it likes to do so. There is a circumstance which has forcibly struck my mind many times, but which I have never seen noticed, and that is that the plumage of the Crake does not get saturated with wet. April showers are proverbial, and, if thunder showers, they are very heary ones; but directly the rain is orer and the sun glints out, you hear "crakc-crake-crake," and the birds are searching for food. Small snails crawl up the grass-stems, and hosts of small winged creatures seek for shelter perfectly dry beneath the grass-blacles, where diamond drops are glistening in all directions, ready to drop in showers at the least breath of air or slightest movement from below- 
yet the Rail travels and feeds through it all; in fact a certain amount of moisture is necessary to its well-being. In the hottest part of the year I 893 the Crakes deserted some of their well-known haunts.

I have had one of these birds come and utter its "crake!" within a yard of my feet, as I stood concealed in the thick cover that edged a woodland meadow. The cry then sounded very different from its usual voice, instead of "crake-crake," it was like the "querk-quark, querk-querk-quark" of a little cluck. Any one not used to the bird would have taken it for some half-grown duck that had come out in the grass snail-hunting. But although the cry of the Land-rail sounds different when close at hand from what it does at a distance, there is about the same difference in the cry of the Cuckoo. If you slip beneath some old elm where the Cuckoo is shouting, its cry does not sound like "cuckoo" at all, but it does directly you get the right distance off.

As a migrant the Corn Crake ranges wide. It is common on some of the sandy pastures of the Hebrides, where, from what information I an able to gather, they are to be far more easily got at than they are in some southern counties in England. At one time, before practical field ornithology had come to the front, as it has clone of late years, this bird was supposed to hide itself for a season, and to pass into a torpid state, the opinion being very prevalent that, as it had never been seen either coming or going, it must remain hidden somewhere 
during part of the year. It can hardly be expected that birds which migrate at night, as Rails and Crakes do, should be seen by people who are in bed and asleep. Times without number have I seen birds on flight, both coming and going, but only once in my life have I seen them pitch down and rest from their travels. They were Swallows, in splendid plumage, fresh from the reed-fringed lagoons and sea-weed-tangled beaches of Africa. I shall never forget that sight, for I could have touched the gentle twittering creatures, as they sat perched in one long line on some fencing.

As all birds of the Rail family are inveterate skulkers, any tuft of tangle or brush will do for them to creep into when they first reach our shores, -not a long flight is it either, if the place of pitching down be on the southern or eastern coast, - and then when night comes they travel again.

I have seen Noorhens up at such a great height that they looked no larger than Starlings. They were circling round and round at a rare pace above a large sheet of fresh water. As I had my glasses on them and saw them ultimately drop down in the water, there could not be the least cloubt as to their identity. Whenever I hear a Moorhen go clicketing overhead, exactly like a Barn Owl, I often wonder how far she is going before morning comes.

Lonely moor-pools are visited by Rails at night, and if they choose to stay there, all well and good, for there is plenty of the closest cover in such places; but as great fields of corn and roots are 
close to the fringe of these moors, the Land-rail gets dropped when he rises at times in the same spots as the so-called Moor Partridges. Sometimes too in the autumn, just before he flights it again, he gets his head into a slight horse-hair noose that was not intended for him.

That some of the Land-rail species have been found in winter is not at all an extraordinary thing, as a few birds of migratory nature generally remain behind, for some reason or other, to get through the winter as best they can. If the winter were a very severe one, I should look for the Land-rail and the Water-rail in places where ordinary searchers, acquainted with only the usual habits of these birds, would never dream of looking for them. Where food and shelter can be found in severe weather, there will the Rails go at night to find such necessaries, knowing that if they do not get them they will die. All their shyness is for a time thrown to the winds.

The Land-rail I have never seen pulled from its warm hicling-place, although one or two such instances have occurred; but the Water-rail I have. It takes a lot to drive him to such extremities, but sometimes there is no help for it. In cases where Land-rails have been met with in winter-time, the seasons have been mild ones. Whether in some instances the Water-rail had been mistaken for the Land-rail I am not able to say; but they have been reported to me so very emphatically by those who knew the two birds perfectly well, that, to my mind, there is not the least doubt of their identity. I have 
so often known birds act quite differently in many ways from their usual habits, that I can see no reason why the Land-rail should not indulge in some such vagaries.

The nest of the Moorhen is a bulky affair, composed of reed-blades, grasses, and fragments of sedges and other water-plants. The eggs, varying in number from eight to ten, are brownish-grey or greyish-yellow in ground-colour, with scattered spots of deep brown, from the size of a small pea down to mere sprinklings.

Green-footed Gallinule would no doubt be the proper name for this bird, but Moorhen is the local name for it, and it is a very good one. Moors, as we all know, are generally associated in people's minds with heather and ferns, but there are two kinds of moors, the wet and the dry. It is in or about the wet moors that you may occasionally see a Noorhen, though not very often, for it draws as near cultivation as man will let it. It is a troublesome neighbour, as it does a lot of harm in the gardens, pecking out the hearts of the young garden stuff, so that it becomes a perfect nuisance sometimes. But as the Moorhens run like rats through the tangle of the moor hedges that enclose the gardens, they are apt to find themselves obliged to stay on the wrong sicle, and never get back. Being grood to eit, their bodies compensate a little for the mischief they do, but a couple of Moorhens will hardly make up for the valuc of a bed of young cabbages pulled to pieces. 
The Moorhen domesticates itself, if the least encouragement is given it, coming to feed with the ducks with the greatest confidence; in fact these beautiful birds will at times get so tame as to be a little bit troublesome. No matter where you may see it, the bird always gives you the idea that in some way or other it has been near or has mixed with domestic poultry. Its movements when on land lead in some measure to this idea, for it looks like a half-grown black fowl running and picking about.

The legs and feet of the Moorhen are very beautiful studies, illustrative of the perfect adaptation of the organs of locomotion to either the water or the land. I have spent days and weeks, as the chances offered, trying to get all the information I could as to this, as shown in the structure of the legs and feet of all waders, and particularly so in the case of the Moorhen. But to carry out these studies you must have the birds alive, or at least directly after they are dead. It is not the least use softening the legs and feet of fowl that have been dead a couple of days, for by that time something has left them which will never come back, and you might as well try to put the bloom back on a peach after it has been rubbed off. Those who have given such matters a little attention will understand my meaning, but it cannot be explained on paper.

The Moorhen can both swim and dive, and he flies well when fairly on the wing; but as his real flights take place, as a rule, at night, very little is 
known about them. As previously stated, I once saw a flight at daybreak that very much astonished me. The bird shifts considerably about at night at times. When alarmed, it is occasionally very clever in concealing itself, and it will sham death to perfection, cven when caught alive by a good dog, without a feather being injured. If you did not know the bird's little tricks, you would fancy it was a dead Moorhen your water-spaniel places so proudly in your hands, his eyes glistening and his tail wagging, because he knows he has made a clever capture of a wary, hideling bird that is not easily circumrented. There it is in your hand, with legs dangling and neck as limp as a wet rag. All very well so far, but after being stowed away in your pocket, that Moorhen will be out of it like any eel, unless it has been properly secured.

Just a word of warning, before I go on, to those who may shoot a Bittern or a Heron. Nothing takes place, it is said, but the unexpected, and it is true as regards these two birds, for sometimes they are put up where no one would dream of looking for them. But never put one in your shooting-pocket, even if it looks dead, for they are terrible shammers, stealthy in their movements, and if it suits their purpose they can hold on and climb like cats. A man I knew very well had a narrow escape from losing one of his eyes over a supposed dead Bittern.

When the sooty chicks are out, the Moorhen parents have a very anxious time of it, for the Heron is on the look-out for them, and he does a lot of 
wading in the reeds and the swamps all the time young Moorhens are about. They would be far more numerous were they not hunted for so persistently by furred, finned, and feathered prowlers.

Deep holes are avoided as much as possible when the brood is out, because pike are on the watch, and thëy do not watch in vain. If the little birds keep close to the side, in or on the shallows, great chub rush out from their hovers under the bank, and take them as a trout would a fly, for a chub of from three to four pounds' weight is decidedly inclined to be predaceous if he has the chance; so that what with one thing and another the poor little innocents have a rough time. I think that if fishing-tackle makers would fix up lures resembling the young of waders and water-fowl, some waters would not hold so many predaceous fish as they now do in bird-nesting time. I have heard a great many complaints made about the real or imaginary loss of birds where fancy water-fowl are kept, yet when the means for very easily capturing their persecutors were pointed out and shown, they were never adopted. But this did not concern me, as I never had to pay for the mischief done.

When the Moorhens nest close to houses or to buildings used for farm purposes, they are comparatively safe, and they know it, and are quite satisfied if they can have a very small pool or runnel. They make themselves quite as contented on a little rushpond the size of a small room as if it were a lake of great extent, and perhaps they feel it is safer for them. 
Gardeners do not approve of them, but they look very pretty on a lawn close to the water, where they are encouraged to come in the winter; if fed they will keep about the place. As ducks visit open rivers where shallows are numerous and the banks well wooded, the Moorhens form a lcad up to the food at night, and they are also company, for want of better. At any rate, the ducks frequent places where the Moorhens are, and some very decent shooting is to be had at times. Decent, that is to say, for inland rivers, as they are the heavy homebred birds, that is, birds bred in this country; they are worth shooting by those who have the right to shoot there. At times you would think that they had deserted certain places, but they are sure to be in the tangle somewhere. When heavy rains have fallen, suddenly flooding the river-bank high, and in some places over the banks, you will see them bobbing in and out like a lot of farm-yard pullets, by the hedges, where they have gone for food and shelter.

This bird has increased of late years to a very great degrec, and this may be fairly ascribed to the gun tax and the Bird Act, and also to the more restrictive measures connected with notice-boards, which now affect people's movements in certain directions. But even if these had never cxisted, the bird would have been seen and heard as usual, for, like the sparrow, he is hardy, and hard to move.

The Bald Coot makes its nest of reeds, Hags, mares'tails, and bits of willows. It is a clumsy 
structure to look at from a short distance, but close inspection proves it to be compact and very strong. The eggs, numbering from six to ten, are larger than those of the Moorhen, but similar in colouring, being light yellowish-grey or stone-colour, marked all over with dots and small spots of brownishblack. The young birds are covered with black down, the hind-part of head being yellow, the frontal membrane livid, and the legs and feet dusky green.

The Coot is local to a certain extent as to habitat. Large stretches of water of moderate depth where flags, reeds, and mares'-tails grow in abundance, are the places in which to look for these birds. If the least degree of protection is given them they are not shy, for, like the Moorhens, they soon become almost as familiar as domestic poultry.

I have seen scores of their nests on one piece of water near me; some of them were built up from the bottom, where the water was shallow, being raised up to a considerable height; others were fixed to clumps of sedges. No matter how or where they were placed, the birds were continually building them up, the mares'-tails (equisetum) being their favourite water-plants for that purpose. Sometimes both birds would work in the most business-like manner, one diving and bringing materials, the other placing them with bill and feet. When one got tired of diving-for the whole plant is brought up-the other would take a turn at it, the diver evidently thinking it time to turn builder. They 
seemed to thoroughly understand the principle of the division of labour.

After the young are all out for the season, some of the nests are used as resting-places at night by the whole family. In building up for a restingplace, all the young birds, which are nearly as large as their parents, would dive for material, and bring it to the old birds, who were adding to the base, scratching and combing vigorously. Then they would set to work to widen it, and some of the brood would get in for a rest and be moved out at once by their parents. A Coot's leg and foot will provide a good day's study; and if a wounded one claws your hand you will remember it for a long time, for you might just as well have a cat clawing at you.

Coots are good to eat, but they are not often brought to table; because if not plucked at once, while still warm, the down covering the body is very difficult to remove. Very few cooks will deal with Coots if brought in cold. The skin could be taken off to save trouble, but that, in the opinion of those who care for the birds,-I do not myself,- - would spoil them.

In some counties these birds are shot in great numbers, but as a rule they are not interfered with. On mill-ponds or ornamental waters where they only exist in moderate numbers, ten or twelve pairs on any water suitable for them, they are most interesting, for they are continually on the move or playing strange antics. When the broods 
are quite fit to take care of themselves, and have learnt from their parents how to get their own living, the old birds drive them off from the water where they were hatched out to find homes for themselves, so that there is not the least fear of a small bit of water becoming overstocked. When hard weather sets in, the Coots visit the tide for a time, returning to their accustomed haunts directly the water is open for them. If any one of my readers captures a Coot, let him keep a sharp look-out for scratches.

\section{THE WATER-RAIL.}

\section{(Rallus aquaticus.)}

MaLe. - The bill dark brown; edges of the upper and part of lower mandible light red; upper parts olive brown, the middle of each feather streaked with brownish-black; some of the feathers on the edge of the wing barred with black and white. Primaries and outer secondaries dusky, tinged with olive; inner secondaries and tail like the back. Throat greyish-white; fore-part of neck and breast dull greyish-blue; belly cream-coloured, the sides barred with black and white. Lower tail coverts cream-coloured, barred with black; iris red ; legs and feet light reddish-brown. Length, from bill to tail, twelve inches.

Female.-Similar to male, but the tints are lighter and the red on the bill duller, and the legs tinged with green. 


\section{THE SPOTTED CRAKE.}

\section{(Porana maruetta.)}

MALE.-The bill brownish-yellow, at the base brighter. Upper part of the head, hind-neck, back, and scapulars olive brown, each feather having an oblong patch of the latter colour. The hind-part of back has small white markings; the wings of a lighter olive brown, the margin and outer edges of the first quill white. Secondary and smaller coverts are marked with small spots, white in the middle, black at each end; inner secondary and coverts barred with white; tail feathers black, margined with olive. Over the eye a broad grey band dotted with white. The forehead, throat, and cheeks bluishgrey, the latter speckled with black. Fore-part, sides of neck, and front part of breast greyish-olive, spotted with white; sides of body light olive, barred with black and white; lower tail coverts buff; iris reddish-brown; legs and feet yellowishgreen. Length, from bill to tail, nine inches.

FEMALE.-Similar to male.

\section{BAILLON'S CRAKE.}

\section{(Porsana bailloni.)}

MALE - The bill dark green; upper parts of plumarre light reddish-olive, marked on the top of the head with black streaks. On the back and on all the wing corerts are numerous white spots, surrounded with deep black. The throat, a streitk 
over the eyes, sides of neck, breast, and belly bluishgrey. Flanks and lower tail coverts marked with broad bands of deep black, and narrow ones of pure white; iris red; legs and feet flesh colour. Length, from bill to tail, seven inches.

Fevale.-Similar to male.

\section{THE LITTLE CRAKE.}

\section{(Porzana parva.)}

MALE.-The bill rich green, red at base; upper parts greyish-olive; all the feathers blackish in the middle. On the fore-part of the back a large black patch, varied by some white marks, thinly scattered ; flanks marked with brown and dull whitish bars. The throat, a streak over the eyes, breast, and belly bluish-grey, without any spots; under tail coverts black, barred with white; iris red; legs and feet bluish-grey. Length, from bill to tail, eight inches.

Fexiale. - Upper parts reddish-brown; black patch on fore-part of back, variegated with a small number of white spots. Throat whitish; eye streak and sides of head light grey; fore-part of neck, breast, and belly reddish-grey.

\section{THE CORN CRAKE.}

(Crex pratensis.)

MALE.-The bill light brown; iris light hazel; upper parts of light yellowish-brown, each feather with a spot of brownish-black. Wing coverts light red, some imperfectly barred with white. A broad 
band of ash grey passes over and behind the eye; the face, fore-part, and sides of neck light yellow ishbrown, tinged with grey. The sides and breast barred with light red and white; quills and primary coverts light brown; the outer webs tinged with light red: legs and feet flesh colour. Length, from bill to tail, eleven inches.

Fimale- Similar to male.

\section{TIIE MOORHEN.}

\section{(Gallinula chloropus.)}

MALF. - The bill greenish-yellow beyond the nostrils, the base and frontal plate crimson red. The iris, which at a little distance looks red, is composed of three rings: the outer hazel, the middle dusky, and the inner bright red. Head and neck deep dark greyish-blue, the belly a paler grey. Some of the long side feathers are banded with white. The back and smaller wing coverts are decp olive brown; quills and primary coverts dark brown; the secondaries tinged with olive. Tail blackish-brown, under tail coverts white; legs and feet green, tinged with yellow, with a ring of bright red above the tarsal joint. Length, from bill to tail, fourteen inches.

THE BALD COOT.

\section{(Fillica atra.)}

Mate-Che bill pale red at the base, white at the end; the frontal plate bluish-white. The 
I60 IIILD-FOWL AND SEA-FOWL OF GREAT BRITAIN head and neck are greyish-black; lower part of neck and upper parts of body dark bluish-grey. Edge of wing and outer margin of first quill whitish; legs and feet blue grey, tinged with olive. Length, from bill to tail, eighteen inches.

Female.-Similar to male; tints not quite so pure. 


\section{CHAPTER XIII}

WILD SWANS

Tinat grand bird the Whooping Swan can only be considered a very uncertain visitor to England, as his visits depend in so great a measure on the severity of the weather. Scotland and Ircland are more favoured by him, being visited at times by very great numbers of these beautiful birds. As the fowlers who have shot on the tide there have given most accurate and minute accounts of them, I shall confine myself to simply describing what I have seen when shore-shooting.

As a rule the winters are not so severe now as they were in my earlier years, when I have known it freeze for weeks without a break; and when the crcek would be filled with floating ice, to say nothing of the vessels which were fixed as tight ats if they were jammed by it. When the tide was high and rough, the cracking, grinding, and crunching used to be something to remember. In such weather a few swans would visit the more lonely parts.

In some parts of Scotland, and notably so in Irelind at the present day, very great prejudices exist against shooting wild swans; in fact, so strong are they that some fowlers would not shoot a swan 
on any account, for fear of such an act being followed by some dire misfortune. Even on my own part of the coast these birds were regarded with a certain amount of respect, for their cries, and the swish, swish, swish of their mighty wings as they passed on their way at night, kept them in many instances from being fired at, even by shooters who were very eager to pull trigger at anything in the shape of fowl that might be seen either on the marshes or above them. I knew some who were not thus withheld from shooting the swans, but these were among the younger spirits, and although these paid some deference at times to traditional rules, they were not quite so tied by them as were their elders. What really became of those that were shot I do not know, beyond the fact that one or two were skinned to make tippets of. Five shillings would buy one of these at any time, so they were not thought much of there, whereas a crown-piece was.

Our domestic swans, at least they may almost be regarded as such, get decoyed away at times and visit the tide, but the difference can be seen at once, after it is too late, and the bird has been shot; especially if "swan marks" are on the upper part of the bill.

Bewick's Swan is the small wild swan of the fowlers. Seven is the greatest number I have ever seen of them together, and, like the Whooping Swan, it can only be considered as an irregular visitor to English coasts, and particularly so on the southern ones where I have seen them.

The American Swan and the Polish Swan I shall 
only mention, without going into details. Others must decide the point as to whether they are distinct species or merely varieties; I have never seen them myself in a wild state.

Swans have a buffish tinge on the head and a little way down the neck; and this, I believe, is caused by stains from the bruised roots of plants that the birds nozzle and spatter in under the water. Some roots stain very much when bruised, as I have found after searching with my fingers for things that were out of sight under water.

\section{THE WHOOPING SWAN.}

\section{(Cygnus musicus.)}

MALE, - The bare space on the forehead, and from the base of the upper mandible to the eyes, is bright yellow; basal part of bill and part of the base of the lower mandible also yellow; rest of bill black; iris brown; legs and feet black. Length, from bill to tail, sixty inches. Wings, from tip to tip, ninetyfive inches.

Female.-Differs from male only in being smaller.

\section{BEWICK'S SWAN.}

\section{(Clgnus beriticki.)}

MaLL:- The bill black, with the exception of a bright ycllow triangular patch on each side at the base; iris brown; legs and fect black. Lecngth, from bill to tail, forty-five inches. Wings, from tip to tip, seventy-four inches. 


\section{CHAPTER XIV}

\section{GUR WILD GEESE}

Tine Greylag Goose is the only wild goose which remains with us all the year round. Numbers of these birds rear their young in the remote parts of Scotland, their nests being large structures composed of the various kinds of herbage to be found in their nesting haunts. The eggs, which are from six to eight in number, are of a creamy white. Although generally a most shy and wary bird, the Greylag becomes bold in the nesting season, quite altering its usual habits. The gander keeps close to his mate all the time she is sitting, ready alike to warn her of coming danger or, if necessary, to fight for her.

As this bird is a feeder on the green crops, and takes care to feed itself in a close and systematic manner, it is not welcomed as a visitor by the farmers. "A wild-goose chase" is a well-known saying, but its full meaning is best understood by those who have tried to get at wild geese when they are feeding on the green crops.

The Greylag is recorded as nesting one hundred years ago in the eastern fens of England before 
they were drained. It is a matter for conjecture whether it was this bird which supplied the feathers for the yard-long shafts which did such terrible execution in the good old days when English archers drew the bowstring out to the head. One reads of how the "grey goose shafts went merrily home," which means that they went in at the breast and out at the back-but those arrows may have been feathered from other grey geese which will be noticed further on. Very great confusion has existed and does, I think, still exist in the minds of the general public with regard to the grey geese. Judging by my own experience, I should say that not one wild goose in twenty shot in this country is a genuine wild Greylag Goose ; the geese procured have turned out to be birds of a different build and colour. They were grey geese, but not the Greylags.

The Bean Goose is a migrant which visits our shores in very great numbers; in fact it is the "Wild Goose" as known to shore-shooters. Its habits are similar to those of the Greylag.

Very awkward mistakes, and sad ones too some of them, have been made sometimes when these birds have been feeding on the saltings and marshes close to the tide, for at certain seasons the geese will feed at night, and then is the time to go after them. On one occasion a fowler shot his horse by mistake, and at another time a man, who was well known to me, shot his own son. Such incidents were once only too common. Fowl, feeding at night, bunch 
themselves up, taking strange shapes, and, when alarmed, they run before flighting.

The Pink-footed Goose might really be just as well called the Grey Goose, as is its larger relative the Greylag, which has received the title. Of the two birds the Pink-footed Goose has the more grey about it. This bird is a migrant, but it has been found breeding in the Northern Isles. The less, however, that is said now about where some birds nest the better. Strange to say, it seems to be only some people who can find out where particular birds build. Can it be that money finds out for them? There are some very clever and conscientious collectors among my acquaintances; but there are others whom I have not the least desire to know anything about; to wit, such as those who will paint birds' eggs.

The White-fronted Goose is a smaller species than either of the preceding ones. It is a frequent visitor to our country during the winter. The Laughing Goose is a name often given to it, on account of its hoarse note, which is supposed to resemble a laugh. Specially large flocks come to our coasts during severe weather on the other side, but it is quite uncommon on most of the east coast of Scotland. In Islay again, it is commoner than any of the other grey geese.

The Bernacle Goose is also a winter visitor to our islands. The Brent Goose is sometimes wrongly called by this name. In severe weather mixed flights of White-fronted and Bernacle Geese some- 



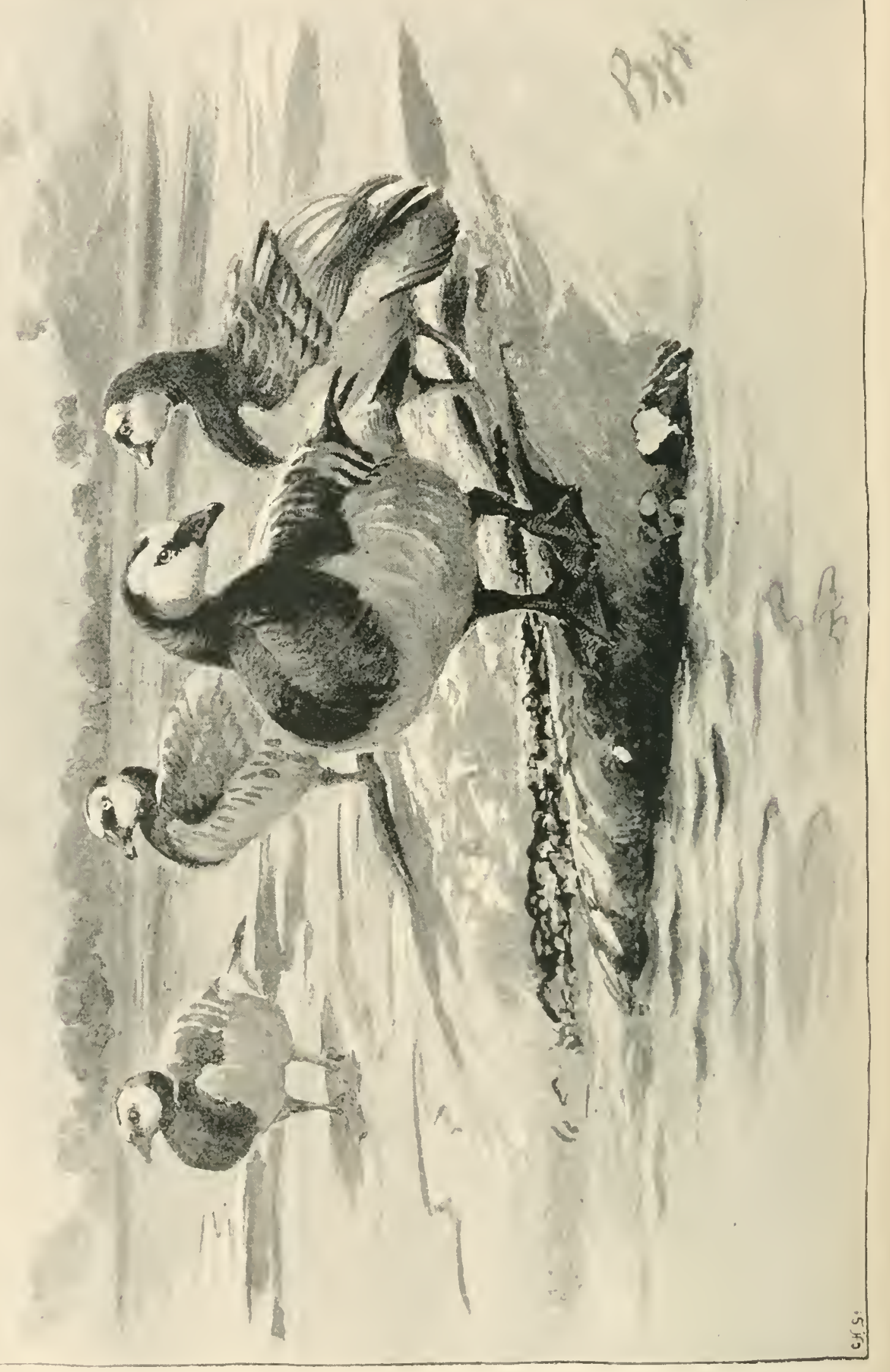

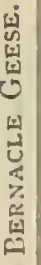


times passed over our North Kent marsh-lands, and strange confused cries were the result-crics that often filled our superstitious folk with terror. Then it was that many of the fowlers would keep indoors, becausc, as they said, "there's bad luck when the Hell-hounds is on the hunt." Except during exceptionally hard weather, however, the Bernacle Goose is very rare on our southern coast. It is less uncommon on the western parts of our shores; and it visits Lancashire and Cumberland freely. About the Solway Firth many are seen at times during the late autumn and the winter. Those geese which have been already noticed feed on grass, clover, and grain. To procure this food they frequent meadows, marshes, and cultivated land, retiring for rest to sand-bars that are not quite awash, or to other lonely places where they will be safe. But the Brent Goose has different habits. It is a sea-bird, keeping out on the tide, coming in to visit the mud-flats when the water has left them, in order to feed on the marine plants, more particularly on grass-wrack (Zostera marina) and laver (Ulva latissima), both of which grow so plentifully on certain mud-flats.

This goose, which visits us from northern lands, from the time of its arrival to that of its departure, is the goose to which fowlers both on the tide and on the shore give nearly all their attention, for a good shot at the black geese pays a shore-shooter well, and is very satisfactory sport to gentlemen-fowlers on the tide. 
One reads a great deal of nonsense written by people ignorant of their subject about wholesale slaughter and extermination of the fowl. They do not know how few fowl, in proportion to the numbers that visit our shores, are shot, nor of the dangers and hardships of going after them. Fowling on the tide for Brents calls for not only pluck and coolness, but requires great endurance as well. I will give a brief sketch of one such night of "wholesale slaughter" (sic).

Snow lies everywhere. Where it has not drifted, every spot is covered with it for two feet or more in depth. Where it has drifted, the thatched, low cottages of the hamlet are snowed up to their very eaves. Where the tide has flowed up over the mudflats there shows a great dark plain, while all around is covered by a grey pall of snow, looking weird in the sickly, foggy moonlight. The fowlers say that either more snow is going to fall or a change is coming-" One or t'other" they say it will be. Those dim masses on the rising grounds in the distance are large military establishments, and that huge object which seems to block the mouth of the river which here meets the tide is a Government dockyard.

The news has spread, as it does somehow or other get spread in these small places, that a couple of fowlers, who have for a time located themselves in this out-of-the-world spot, are going out for a shot when the tide flows. Such a rumour is enough to make all the shore-shooters and all the fishermen 
who are at home hold themselves in readiness to turn out when the time comes, in order to see the expedition well off, for the fowlers have made friends with all these good fellows.

The ticle is up, and from the door of the small public-house where they have taken all the rooms that could possibly be spared, the two fowlers step out muffled as if for a Polar expedition, and indeed it is not so very far removed from being one.

"All right, gentlemen," says the spokesman of the group that has been waiting outside, "if so be as you ain't no objection like, we be cumin' to see ye off, an' bear a hand, if we ken, to git her out o' the drift-ice for open water."

"Thanks; you are good fellows to think of us," is the reply, and then among that group there arises a call for "old Coleman," and a grizzled old fisherman steps to the front.

"You must be pilot, Coleman, for you knows better 'an most on us what can and what can't be done on a night like this."

Thus acknowledged as leader by his neighbours, old Coleman takes the lead, merely remarking that " if she ken be got out, there will be a chance; fur the geese have guzzled fur nearly a week without bein' got at, 'cos o' the ice. Hark at it rattlin' an' crunchin', as if a couple o' three-deckers was aboardin' o' each other."

Arrived at the rough shed at the water's side where the punt was, with a man to keep guard of herself and her gun, a consultation was held as to 
the best means of getting her out. As the drift-ice was naturally close in to the shore, the punt, if once got clear of it, would be all right, and as there was no wind, matters were not likely to be hopeless. In fact the thing was soon settled, one or two lanterns throwing a friendly light on the subject, while a couple of stout skiffs made their appearance from somewhere, each holding a couple of men, one with a pole and the other with a scull-oar just to kcep way on her.

When all was ready, the order was given to "douse the lanterns," and the start was made, the fowling-punt being actually towed out into open water by the two skiffs. It was not a long job, only just a cut of the creek, and a short one fortunately, for thousands of them exist out of sight, a circumstance which makes this part prove treacherous to strangers, and sometimes even to the natives themselves.

In about twenty minutes the skiffs returned, bringing the interesting information that the geese were close in. There could not be the least doubt about that, for their clang could be heard like a pack of hounds coming over the water. The geese had fed well, as, although there was drift-ice about, none had formed on this part of the sheltered mudflats: what ice there was was only travelling drift brought up by the tide from below, and was not thick enough to injure the punt, only sufficiently so to make it inconvenient for her to get out by herself. The small company of fishers and shore-shooters 
who stayed behind were very cheery as they waited at the back of the shed where the punt was kept under guard; not because there was even the least fear or suspicion of the people from the hamlet, but because river prowlers now and again would come like grey shadows from nobody knew where; and, taking what did not belong to them, would depart, knowing that the water leaves no trail to track by. Two dumpy bottles were going the round in a silent but perfectly satisfactory manner, and pipes were being lit, while the chances as to the geese were discussed in low, muttered tones, for sounds are heard with terrible distinctness on the water.

Presently old Coleman said, "If there is a chance they will soon hev it; we shan't hev long to wait. If they've guzzled enough, they're restin' on the tide. If they ain't, they'll flight down to Lower Alston an' wait fur the ebb."

Hardly were the words out of his mouth than the roar of the punt-gun reached them.

"Hark," said the old boy, "hark! Stick me in the mud and be d-d to me, if they ain't cumin' inshore to cross over an' down Chetney Ma'shes. Hark at 'em! Don't they crack on! 'Thud, thud! What the devil's that? Is it snowing brickbats?"

"No, it ain't, Coleman; it's snowin' geese. Look here!"

"In'em at last! in 'em at last!" yelled the old man, and the others shouted too. It was enough to rouse all the fowl on the flats. No caution now. Out went the skiffs to pilot the punt in, and lanterns were lit. 
"Here she is! What luck? Twelve gathered!"

"Yes," cried a voice, "an' two dropped ashore. Here they are. Seven couple o' geese! Hooray!"

After everything had been made right, the party returned to the public-house. Very late at night, or indeed it may have been early in the next morning, Coleman was heard cheering the hearts of the company with songs of a warlike character. One chorus in particular was much appreciated-

"For matchless was he that ruled the seas; His name like his fame Immortal shall be."

This was followed by the "Pirate of the Isles," a ditty of the most ferocious words sung to a very heartrending tune. But the grand piece of the evening-for, as one of the party said, "the old boy was crowding on canvas"-was the "Mutiny at the Nore," which was given with great expression and feeling. I shall never forget it as long as I live, for the old boy looked graver than any owl could possibly look, even if it were to try its best, and this was the chorus-

"Parker he was hung for mutiny, That's a thing you can't deny ;

In a coach an' four they went to London, 'Cos poor Parker shouldn't die."

If those gentlemen-fowlers are alive now, and indeed I sincerely hope they are, they may guess who the writer of these pages is, for he was one of the party on that occasion. 


\section{THE GREYLAG GOOSE.}

(Anser cinereus.)

MaLE. - The bill orange; the nail whitish; iris brown; head and neck greyish-brown. Upper parts grey and brown, bordered on the terminal margins of the feathers with greyish-white. Front part of under plumage ash grey, barred on the belly and flanks with brown; behind pure white; legs and feet flesh colour. Length, from bill to tail, thirty-three inches.

Fenale.-Similar in colouring, but smaller.

THE BEAN GOOSE.

\section{(Anser segetum.)}

MaLE.-The bill orange; base and nail black; iris hazel; head and neck greyish-brown. The fore-neck and breast are gradually shaded with a paler brown, fading into greyish-white. Upper plumage deep greyish-brown, narrowly edged with brownish-white; legs and feet orange yellow. Length, from bill to tail, thirty-one inches.

\section{THE PINK-FOOTED GOOSE.}

\section{(Anser brachirhynchus.)}

MaLE. The bill orange carmine; the base and nail black; head and neck reddisls-brown. Upper plumage ash grey, edged with greyish-white; under plumage fawn-coloured in front, white behind; legs 

and feet pale lake colour. Length, from bill to tail, twenty-eight inches.

\section{THE WHITE-FRONTED GOOSE.}

\section{(Anser albifrons.)}

MaLE.-The bill orange yellow, the nail white; iris hazel; edges of the eyelids orange. A pure white space on the forehead, surrounded by a dusky band. Upper plumage ash brown, varied with grey, black, and dull white; front part of under plumage brownish-white, with bars and patches of black; legs and feet orange. Length, from bill to tail, twenty-eight inches.

FeMale.-Similar to male, but smaller.

THE BERNACLE GOOSE.

(Bernicla leucopsis.)

MALE. -The bill black; iris hazel; forehead, throat, and sides of head pure white. A dark streak between the eyes and bill; head and neck black. Upper plumage undulated with black and ash grey; the feathers with a narrow terminal band of greyishwhite; quills and tail black. Lower plumage white, tinged on the flanks with grey; legs and feet black. Length, from bill to tail, twenty-seven inches.

\section{THE BRENT GOOSE.}

\section{(Bernicla brenta.)}

Male.-The bill black; iris hazel; head, neck, breast, and tail black. On each side of the neck a 
patch of white, with a few black feathers intermixed. General colour of upper parts dark brownish-grey, margined with light greyish-brown. Quills greyishblack; the breast and sides brownish-grey, barred with greyish-white; upper and lower tail coverts white; legs and feet black. Length, from bill to tail, twenty-five inches.

Feurale.-Differs from male only in having the upper part more tinged with brown. 


\section{CHAPTER XV}

THE SIIELD-DUCK

THE nest of the Sheld-duck, which is placed in a hole in the sand, is constructed of dry herbage, and contains from seven to ten eggs, which are white tinged with red.

The Sheld-duck itself, which is a beautiful bird, belongs, one might say, to the sand-hills that line so many parts of our shores. It is known under several different names, such as Burrow-duck, Berganser (or Barganser), Skelgoose, Sheldrake, and Skeeling-goose, and these titles are sometimes a little confusing. People who know the coast only by visiting it at certain times when they think fowl are about, have occasionally some very curious birds provided for their especial benefit, for setting-up. A good bird very rarely leaves the place where it was procured.

The sand-dunes are very different to what might be imagined by some people who had never seen them. They are vast stretches of as up-and-down a formation as a man might ever wish to travel over. Some of them, the marsh-hills, are almost closed in 176 



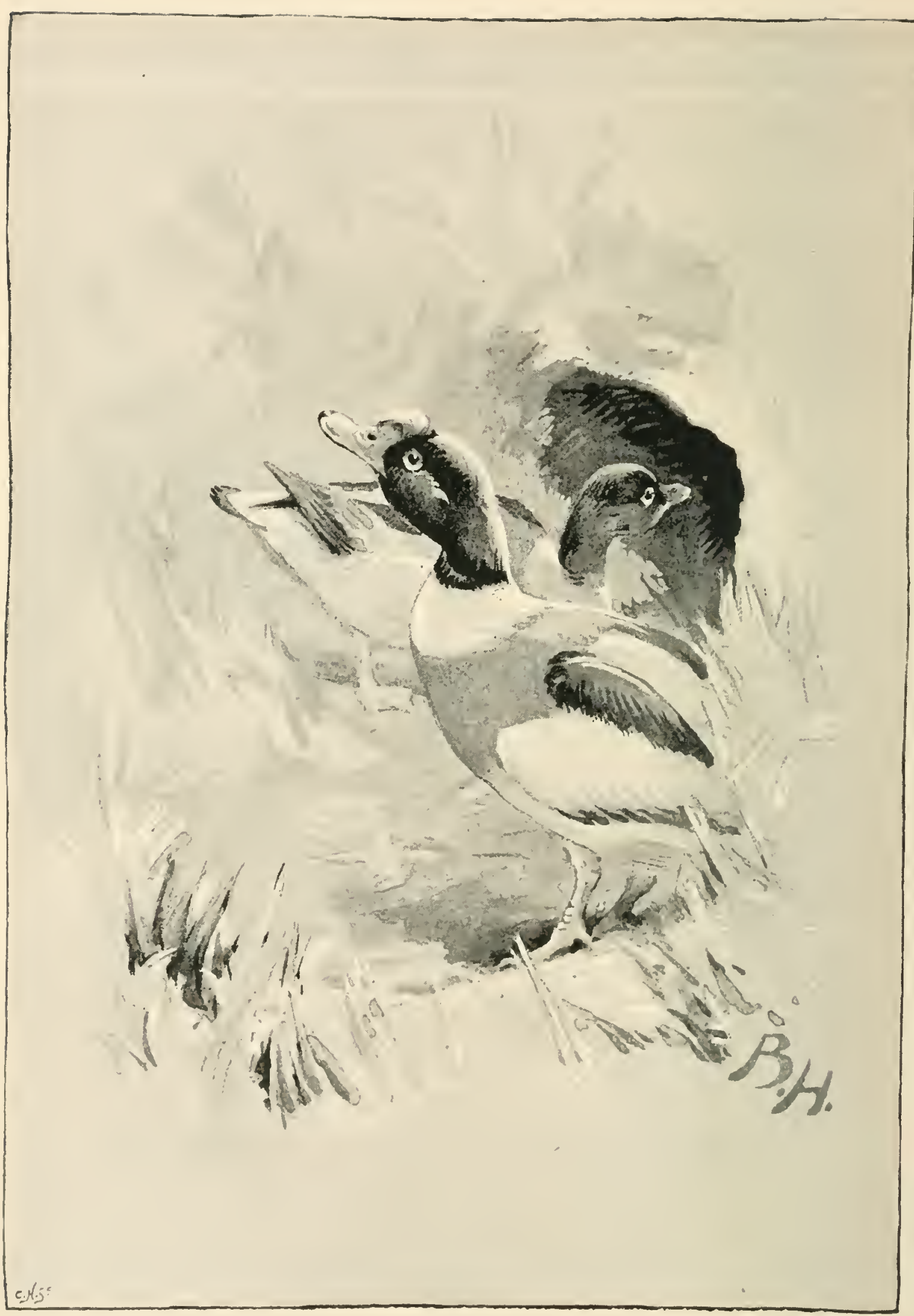

SHELD-DtCK. 
by the ticle, and when the sea comes thundering in, the lower parts of the marsh-dunes get covered. When the storm abates and the water runs off, great pools of salt water are left in some of the hollows, destined to evaporate ultimately as the sun bends his genial heat down on these haunts of the Sheld-cluck. Beach litter, such as stones, pebbles, broken shells, sca-wrack, and tangle, is strewn all over the place where the hollows lie near the tide. Bents, sea-holly, and sand-convolvuli, and in all directions stunted, starved, prickly thorn-bushes, are dotted about. The whole place is honeycombed with rabbit burrows; no wonder the shooters keep open order, very wide apart, when at rare intervals these desolate places are visited. As some of them are completely surrounded by water at high tide, a boat is necessary; the full consent of the owner is also needed, as the sanddune warrens are rented. The rabbits do fetch something, but it is for the sake of their skins that they are captured, for in winter the wind cuts like a knife, and the fowlers need to have good jackets on. In the summer, so very trying are these places that I have known the best fowler out of the lot-one who would think but little of plunging into salt water in the dead of winter in order to gather his fowl before they drifted away-completely done up, and the other men were in worse plight than he was.

The dunes are sandy wildernesses of all shapes and sizes, a perfect maze-when you reach the heart 
of them-of hills and hollows in whose placing there seems to be no order. The white scuts of the rabbits show continually, as they dot about from bent-tufts and thorn-scrub. Eagles in immature plumage, generally Sea-eagles, visit the dunes and prey on the rabbits that swarm here when they are on flight. So do also the Falcons (Peregrines these are, rarely a Gyr-Falcon) and the larger Hawks, with the Owls to help them. If the Raptores were to stay for a year without being checked, they would only slightly thin off some of the pinwire sea-weed munchers. But this they are not permitted to do without some interruption, as they are themselves worth far more as specimens for collections than the rabbits they feed on. However, all of them do not get shot, far from it. If it is the sea-breeze that gives them extra ideas on the interesting subject of self-preservation to add to their usual keen ones I do not know; but they are very difficult to get at. This difficulty may be owing to the Cobs, which are continually on the beat over these sand-hills, always keeping out of harm's way themselves, and giving the alarm to all whom they perceive to be getting near danger. When the Cob beats to and fro over the dunes well up out of shot, you may crouch and hide, but his keen eyes will be sure to see you, and he will cackle loudly just to let all the other birds know he has seen something. The worst of it is they all believe in him.

Catch a Cob asleep, if you can. One of my fowling friends once thought he had got one of these 
fine birds, for, as he cautiously crawled up a sand-hill to look over, he spied a fine Cob in all the glory of his summer plumage, feeding on a large fish that had been washed up. The bird was just a little too far off, to make quite sure; so down the shooter slipped and did a back-aching crawt to get at him. Cocking his gun, he sncaked through a lot of bents and thorns, and then looked very cautiously. There was the gull on a spit of sand a quarter of a mile away, cackling like a "natural." The Cob had seen the fowler, and declined to have any nearer acquaintance.

It is out at sea, when the Cob comes with others to tear the fish out of the nets as they are hauled in, that he gets it; and it serves him right, for at such times he does a lot of mischief in a very businesslike manner. Bad luck to the little Sheld-ducklings if he catches them on the paddle; but this rarely happens, as they are well looked after, and know how to hide themselves if danger is near.

Very little escapes the eyes of a warrener's lad. This one is barely fourteen, but the place is as well known to him as his own home, for at times he almost lives here. He knows where the Terns and the Dotterels nest, also the Sheld-ducks, which, he says, in the most quict, matter-of-fact way, are "wuss than foxes for artfulness." Some of the nesting-holes he has discorered by seeing the old bird either go in or come out while he lay curled up in the bents watching for rabbits - for the lad shoots as well as traps. Others he has traced through 
seeing the prints of the bird's webbed feet near the burrow. To ordinary observers it would be an impossibility to tell which burrow held a rabbit or which held a Sheld-duck, but the lad knows, and makes no mistakes about it. When the shooting party that I have previously mentioned left the dunes, that lad was not distressed, although he had been guiding the fowlers all day. Judging him by their own feelings, they had been solicitously anxious about him for some time, but he told them simply enough that he was used to it all the year round, "trapesing the dunes"; it did not make any difference to him.

The nest of the Sheld-duck is well supplied with down, after the usual fashion of the duck family. Directly the young birds are fit, off they are taken to the tide, and then you may say good-bye to them. Sometimes the eggs are taken just before the full complement is laid, and they are hatched out under either hens or ducks. As this bird is very handsome and carries itself well, it is in some request for ornamental waters. But even these young birds are "kittle cattle," and require a lot of looking after. One of its local names, that of Sly-goose, gives the clue at once to its character, for it is a bird which requires a lot of getting at. Although the dunes and the rough, broken, sandy pastures, sprinkled with stone and dwarf furze, are its usual habitat, the Sheld-duck flights the shores to feed, its food being little different to that of the other birds: there are no bounds as to where you may sec fowl, especially 
the one now under notice. It is conspicuous when on the wing, so that there is no great difficulty in picking it cut from the others. The flight is something between that of a goose and that of a duck, and one thing I know about these geese is, that they travel faster than they appear to do.

The eastern coast is frequented by them for nesting purposes in preference to the southern. There are exceptions, for one lot of sand-dunes is like another, find them where you will, and in all cases the coarse vegetation and the general surroundings are the same; but fowl come and go at no man's bidding. In places which were suitable for the Sheld-duclis they have sometimes not been met with; and in other instances, when looking out from a seawrack hiding-place for Curlew, just as it was getting light, a couple have come leisurely flapping along just on the edge of the tide, and, you may be very sure of it, just out of shot. You can keep still if you do see them coming; it is no use to run down the beach for a shot; they are not divers, so you may lie still and bear it. Sometimes you can load and fire as quick as you cann, with, if you hold straight, fair results; another time you may come home after hours of weary look-out, cramped and cold, to breakfast, with only a Grey Plover and three or four Sanderlings in your pocket. It is a game of chances, and as a rule they are in favour of the bird you are after, but it is a consolation to know that the fowl are about somewhere. 
THE SHELD-DUCK.

(Tadoma comuta.)

Male. - The bill, and knob at its base, bright carmine; the nail dusky; iris brown. Head and neck glossy blackish-green, with purple reflections; a broad band of white succeeds, then another of orange red, encircling the fore-part of the body. Rest of lower parts white, with the exception of a band of black on the breast and belly. The feathers below the tail sienna yellow. The middle and hindpart of back white; also the tail, the six middle feathers being tipped with black. Wing coverts and secondary coverts white; primaries and their coverts greyish-black. The outer secondaries are glossy green externally; three of the inner are light red externally; legs and feet flesh-coloured. Length, from bill to tail, twenty-four inches.

Female.-Smaller than the male, and differs in wanting the knot at the base of the upper mandible. 


\section{CHAPTER XVI}

TIIE COMMON WILD DUCK

The Wild Duck, or Mallard, as it is more generally called by all fowlers - it was always Mallard when I lived near that noted decoy about which there will be something to say before we have done with this bird-has from those earliest times when the monks of Crowland netted them in vast numbers, been a fowl that all fully knew the worth of. At the present time the Mallard takes the front rank as a wild fowl. Endless quibbles have arisen, and to little purpose, as to the origin of some of our farm-yard bircls; I clo not think there need be any doubt in connection with the Mallard. I have seen a farm-yard drake so much like the wild one that it would have been impossible to tell the difference between them, setting aside the question of size. It is the same with geese; where they are kept in large numbers, and have wide ranges, individual birds can be seen which are cxactly like the wild Greylag.

The Mallards pair, so do the half-bred ones; which plainly show's that in some cases civilization demoralizes, for the drake of the farm-yard is a free 
lover. The way in which half-bred ones are got is this: some tame ducks of the original colour are turned down with some pinioned wild drakes, the domesticated drakes being cooped up or sent elsewhere, with the result that in the course of time a lot of Wild Ducks very soon gather together, and keep to the district in which they were hatched out. The tame blood inherited from their mothers is just enough to keep them about the water or waters near which the nests were. I very often visit a lot of half-bred bircls which are wild to all intents and purposes, at any rate so far as sport is concerned, and also in their plumage; but they come to be fed at a certain place twice daily. Sometimes these birds wander and nest out; if the eggs are found they are placed under tame bircs to hatch. There is as much difference between these nimble little beauties and the farm-yard birds, as regards size, as there is between a fine tame drake and small gander.

There is a difference in weight in our own homebred wild birds, that is, between Wild Ducks bred in the United Kingdom and the foreign flighters: and when alarmed the latter are quick to spring from the water; they are up and away. Flightshooting morning and evening accounts for the death of a great many. And sometimes fowlers on the tide kill numbers, for the flighters seem to think that, for them at any rate, the open water is safest to rest on; they come off it to feed at night, and return in the early morning. 
It was-we are sorry to write this-from thoroughly knowing the habits of these birds that the fen-dwellers at one time were able to capture in thousands all ducks-that is, Mallards-before the fens, marshes, and flats were drained. The capture of these birds for the markets provided the greater number of the "fen-slodgers" with the means of living.

Wild Ducks do not like a drowned country, where the flats are covered with water for months; they will not stay in it, at least not in a way that would lead to their capturc, because their nature is to spatter and sift for their food in shallow places where there is no need to dive for it. The Vild Duck can dive well enough, but it does not do this for a living; I have watched the ducklings diving in clear water, and a very pretty sight it is.

This bird is a great favourite with shooters because it can, as they term it, "be picked up," when the weather is fairly hard, one here and a couple there, ducks or drakes as the case may be; but, from some cause or other, those I have met with were all drakes. Any warm spring in a hollow choked up nearly by weeds, and sheltered by pollird wiflows, could be reckoned on as a sure spot for a find; small numbers would come in off the tide to feed in the day-time; they had of course been there before, and knew their ground. But they were very wary, cars and cyes all on the alcrt, springing up when least expected, going straight for the opening between the mill and the mill-house, where we dared 
not fire for fear of breaking the windows; and the miller could not shoot for fear of hitting those in front that had put them up. The fowl had enough left-handed blessings sent after them to make their tail feathers drop out. When we come to think the matter over, those day-spattering Mallards were far more trouble to us than profit; but I suppose the same kind of thing would take place again if the chance offered.

Plenty of duck-shooting can be had by those that can afford it; fowling costs money, but it is the sport, not the fowl, that is worth considering. Only a few years back duck-shooting in the season was carried on by every man and lad capable of using a gun; there were no taxes either on a gun or a dog at that time. No doubt we are benefited by the fens and marshes being drained; but in some places known to myself the so-called improvements have been doubtful blessings to the general community.

Flight-shooting is the only chance shore-shooters have with the Mallard; off-chances in hard weather such as we have mentioned do not count. As those men I was once associated with made it their business, the flight-shooting either coming in or going out was carried on in a business-like manner, the chances for and against being calmly talked over going down to the creek. The fowl have their fly-lines, which are rarely deviated from, if it is a good feeding haunt, the principal question being the height at which they fly. If they rise and flight 
from a decoy they can be depended on; that is, the ducks will pass over certain places with great regularity. If they are going out there is the seaward side of the sea-wall for you to crouch on, or under, as the case may be; sometimes with a keen wind blowing that would make your teeth chatter, but that had to be put up with. If spin-drift was about, the salt particles got in your eyes, causing you to shed bitter tears, all for the sake of the poor ducks. If you were on the marsh side of the wall, waiting for them to come in, and things looked prosperous, very often they passed in out of range; and sometimes, without any warning, a sea-fog would roll in and pass over the marsh just before they rose from the 'coy. That was the most tantalizing thing of all ; for you could hear the rapid swit-swit-swit-switswit of their wings cutting through the air like knives, without being able to get on terms with them. Then the fog would smother you up, making you feel as if you had just escaped from a graveyard. No wonder "ager-mixter" was a vital neccssity to our shore-shooters; at such times it would be, "Come on, it's no use; we'd better git home,"-the men having had a three miles' tramp down, and a bad three miles back, all for nothing. When a gale drove them in from open water before their time, the men got something; for the fierce wind kept the birds low.

"Look out! here they come, crackin' on all sail." Then it was beatutiful for about twenty minutes. "Bang! grot him (thud!) all right; you can keep 
busy." (Snick!)-a miss-fire. Some one would utter a very loud "damn!" then you heard, "Got 'em clean right an' left." Thud! Then a faint "querkquerk, quark." Thud again. Then some one would try to get on with his gun at half-cock-such things do take place at times with the best of fowlers in the excitement of flight-shooting, so his chance was gone, with that lot at least. The remarks he made about things in general, himself included, when he found out what was the matter would, as our folks had it, have turned a fair-sized grindstone.

As each man takes his place in flight-shooting, and never moves from it - that was the rule then, and one that was obeyed-there was not the least cause to challenge the shot. Each shooter knew the birds that belonged to his gun. The fowl swish in and out in companies; not like a lot of Rooks, following one another quickly, but generally with gaps between long enough to load in, if you are quick about it. I am writing now about the good old muzzleloaders. No doubt the few ducks procured at that lucky time would be laughed at now, for it is quantity not quality that has come to the front with us; but they were killed clean and fit to look at then, there were no "sink-holes" blown through them.

As duck decoys have been already fully described in detail, I shall only give a few particulars from my own personal knowledge, for at one time I lived near a celebrated 'coy. A decoy for capturing ducks is a very quiet piece of water, generally 
surrounded by alders and willows; pipes, so called, lead from the pond. These pipes are shallowcurved ditches, covered over with netting which is supported by hoops, fourteen, or it may be fifteen fect high at the mouth, gradually diminishing as they curve into a tunnel-net that can easily be taken off and easily replaced. The pipes do not run all one way, they are arranged to suit the shifting of the wincl. Gently-sloping grass-banks rise from the edge of the pond, and these are surrouncled by a hedge or a cover of some kind to keep the wind off, and to prevent the fowl seeing anything. From the mouth of the pipes reed-screens are arranged in such a manner that the coyman can see the bircls, or fowl as they are called, without being seen by them. If he wishes to look at the fowl, he slips a thin piece of lath between the reeds, first parting them a little on one side, and peeps through. Those of my readers who have never seen a decoy will best understand it, when I say that the reedscreens are arranged on the overlapping principle, that is, part of one screen runs by another. The laps or jumps are low barriers that the coyman's dog jumps over on one side of the screen, and out on the other like a flash, to attract the fowl. Those who have as children played the game of "Thread the tailor's needle" will know exactly what the dog's performance is like.

But before this subject is continued, let me give a slight sketch of the Wild Ducks' habits. 'They are more or less night-feeders, coming in from open 
watcr, or from some of the lonely creeks, to feed in the vicinity of fresh water, if it is within a few miles of them. The only motive the Mallards have for resting on open water, or in lonely bays and creeks, is the wish for safety. If they can find a secluded pool inland, they drop down and rest; that is why decoys are constructed. Ducks are keeneyed and keen-nosed, their smelling powers are as keen as their eyesight. Some who have perhaps scarcely seen a Wild Duck have questioned this, but let that pass.

The ducks having found out such a nice piece of water, they frequent it; and not only that, they find food also, and of a delicious quality, with ducks exactly like themselves to show them where it is, and to make friends with them. How very nice! When they "raise" from the 'coy voluntarily in the evening, they tell others in their duck language what a fine resting-place they have found, and they bring these with them until a good "lead" is established. That is in the day-time. The pond is full of fowl, some of them swimming, some on the gently-sloping turf-banks trimming their feathers. Now is the time for what one of our old marsh-trotting friends used to call "a little bit of obfuscation" (deceit). The fowl have not for some reason found the nice food, only little bits of it left behind, what to them looks like from yesterday. But their friends, the ducks whom they had found on the water the first time they pitched, evidently expect to find some, for they swim towards the 
mouth of one of the pipes. There is something there, just inside, some are softly quacking and spattering in the very height of enjoyment.

Up the whole lot paddle; those on the turf-banks leave off feather-trimming and come also. Their friends swim further up the pipe, and they follow. But what of that? What business has that strange creature on the bank of that nice water-way, a beautiful curving dyke with food to be got there? Once more the strange form shows like a flash. The wild-fowl make up their mind to see what it is; they will not put up with this mystery. Away the lot go after it, necks stretched, paddling their hardest; to find that their dear new friencls have left them without their knowing it, and have come back to the mouth of the pipe.

They then catch sight of something far worse than the red dog they have been following up: this is the coyman, who now shows himself, for they are far enough up for him to do so. Up they get, all the lot of them; round the bend they go, the coyman following. But they do not see claylight at the other end, for the tunnel gets narrower and narrower. They are not able to use their wings; down they drop, to rush one over the other into the hooped net at the end, the fatal tail of that long pipe. This the coyman unhooks, and then he at once proceeds to break their necks very neatly and expeditiously.

A short time back that lot of ducks, or we might say ducks and drakes-Mallards-ninety-five of 
them perhaps in number, were at the mouth of the pipe, very much alive. Here they are now, neatly laid out, before being taken away, dead as herrings.

That is how it is done. One system will apply to all the decoys on general lines, and as the art of decoying was carried on in the fens from the earliest times, the coymen from there have gradually taught the art as practised by them to others in other counties. Fowl had always been captured, but the fen-dwellers, although they have been called "slodgers," "web-foots," and "mud-nozzlers," knew more about it than did the marsh-folks. Gentlemen who visited the fens persuaded some of the fen coymen to construct decoys for them, or to re-model those on their properties.

They met with fierce opposition, not shown openly, for various reasons; but a sort of quiet antagonism prevailed, which made matters very unpleasant at times. I have always been well posted in fen and marsh records, and have full particulars of those days, and as to past owners, dates, and the catches round about our own shores on either side.

The fault of some decoys was this, they were too large to be properly worked. Because the marshes were of vast extent as marshes, the marshmen thought the decoy's must be large in order to correspond; but that was a mistake. When the fen coymen made their decoys for them the natives sneered at the small size of these, but when they saw the enormous results of this new departure from their old, very old plan, they quiclily followed suit as 
well as they could. The web-foots and the marshtrotters, however, were never on friendly terms in those days when I lived in the North Kent marshes.

Very strict laws exist as to decoys. It is absolutely necessary, for one thing, that extreme quict should be kept in their vicinity. Any bird of prey or Heron that showed must be quickly got rid of ; within a certain distance no gun dared be fired near a decoy. If a fox got there he had to be got rid of ; -foxes like ducks.

As to pike, if they do get in a decoy-pond, they ought not to; but they do at times when the ponds are away from the ticle. They have to be got out of it, for their vicious plunges at small deer found near cover, that is, near secluded places, will at times raise the fowl. The slush-up of a fair-sized pike in setges makes a very consiclerable noise.

There is always something to be done in or round about a decoy-pond in summer and in winter. In the summer the men have to see to all the detailsthe water, banks, hedges, and the netting that covers the pipes; to stop and firmly plug all holes made by either rabbits or rats, for these creatures will draw near if they can. So they are busy, the coyman and his mate, the latter being generally one of his own sons; strangers they will not have, if they can help it, at any price. So very close and chary of speech were they, that it was a common saying about those that we kncw, that "if you had to talli to them you had better take a crombar with you to upen their mouths with." 
When I first handled a gun, unknown to my parents-and I started that game very early in life - I was told by my tutors in sport, of pains and penalties without hope of mercy if ever I "acted the fool" and fired a gun within a mile of the 'coy. At last I had so much of this that it was difficult to get me to go there at all, even when I was needed to help over technical business matters of detail with my elders.

When I used to sneak in from the marsh after secret expeditions in the "dims," to leave my gun with the one that lent it to me, he would say, "You ain't bin near the 'coy, hev ye? "until at last I hated the very name of it; but it was all made very clear to me as I grew older. The 'coy went, like many more marsh-land institutions, when the marsh was drained. Where they caught ducks at one time they now gather fruit. How places change! For centuries, things go on in one way, no one ever dreams it is possible to alter them. Then a change comes, and before you have time to realize it a new face is on all things. Sometimes it is for the better. It has been so in this case certainly, I know that perfectly well; but it is not always so, and changes are often a trial.

The life of a decoyman was not a very enviable one. His firm belief was that every living soul on the marshes was in lcague against him and his precious ducks. If folks had not already done any mischief, they meant to do it when the chance offered. If he had not had these ideas he would not have 
been a coyman; it would have been an impossibility. That very peculiar race of beings, now fast going out with their decoys, are as a rule most "owdaciously cantankerous." Their whole moral and physical being was centred in ducks, and ducks alone. I am writing from the life. There is only one way to get in a coyman's good graces, and that I will keep to myself.

In hard weather they had to be up all night, breaking the ice and keeping the water open for the ducks to come in from open water at daybreak. As the rush of fowl passed over on their way to the tide, clanging, shrieking, and grunting out their rough notes, no wonder they said that the "hellhounds were out on the hunt," believing that these were the souls of those that could never rest, becanse their storm-washed and battered remains had not received the rites of Christian burial. In dead, creepy wintry weather they said that they were hunted. When the foul phosphorescent marshlanterns showed, as they did at times, then the spirits were searching for the least stray bit of their bones, for they believed that if they could only find a fraction their weary souls would get rest. Shut off from common humanity, only seeing people from the outer world at rare intervals, with not the least chance of seeing one of the old-fashioned newspapers-and when that rare chance did offer hardly being able to get through the meaning of matters, of political matters especially-they were dead set agrainst changes. They were not alone in this, all 
real marsh-dwellers were here agreed that "such things were best let alone for them as understood 'em ; they didn't."

Yet when the call was made on the rough wild marshes "for Queen and Country," they stepped to the front as their fathers had done in the time of the first and great Napoleon. I knew many old soldiers and sailors, when I was in my teens, who reckoned it their proudest boast that they "had helped leather Old Boney." I never heard the great general, or rather emperor, mentioned with his full name or title; he was to them, and always had been, Old Boney.

Just a sketch, let me give, of a coyman's house, before local government and sanitary measures were thought about. A long, low, one-storied building, the thick walls discoloured with all the stains that the foul vapours of the flats can stain with, built of rubble, that is, whatever they could lay their hands on to build with, by fair means or foul. It was old, heavily thatched with reeds, the most durable of thatching, and as it had been renewed from time to time without taking the old off, the thatch was as thick as the walls, cool in the marsh-land summers, and as warm in the bitter winters as any house built in such a place could be expected to be. The windows were lead-light ones, a fixed light and a casement to each opening, heavy oak shutters protecting them at night, secured from within. Some rough flags a little raised kept the inhabitants' feet from sinking into the squash of 
the marsh "when things was a bit damp," in reality wet howling weather, when the rain drove over the bare grass stretches in sheets of water, blotting out for a time all objects, far and near. The floors were brick floors from one end to the other, not "ground for the floor," as the song has it, but the whole of the dwelling was on the ground floor. Some rough furniture, just enough for the bare necessaries of life, was there, and bare white-washed walls, with the coyman's wife's dresser, where all her crockery was displayed with evident pride. Some heads of bulrushes, the giant reed mace, with some reed tassels, crossed each other on the top part, where her idolized "chaney" was placed out of harm's way. How some of her fragile egg-shell porcelain, that she would say her mother had given her, had been kept from harm, was a mystery. Tea, before things were altered as they are now, was a little bit expensive, and a pound of the best "gunpowder tea" as a present was considered something handsome. Not that I ever heard of the marsh-folks buying this. You would hear them ask for lots of things when, at rare intervals, they did come in to a neighbouring town to do some shopping. This was one of their greatest treats, for then they heard how the little edge of the solid earth just outside of them, with its houses and people, was progressing.

Laudanum would be sure to be asked for. That drug or medicine did not walk about the marshes at night, as, unless some folks were grossly mis- 
represented, chests of tea did. They had three remedies in that damp land for all diseases, broken bones excepted - these last cases were very rare. If people fell at times, the ground was soft and they did not come to harm. There was "ager-mixter," in plain words hollands gin, or brandy; "how-do-we" (eau de vie)-this was to keep the damp out when they had night work on hand. Hollands? well, when it was thought necessary, and that was pretty frequent. Spirits and water, hot water, not cold-some of our water needed boiling, and at times straining a bit. But the laudanum bottle, and it was not a small one, was the sheet-anchor for them. Twenty to almost any amount of drops on a piece of loaf sugar, this being kept for that special purpose, was good in their opinion for all inward pain. After a time this would create in some a vicious craving, and they would take it in the same way that people take any ordinary dram, and then it did not make them sleepy.

For rheumatism they used goose-grease and hartshorn, well rubbed in with plenty of elbowgrease. They were a hardy lot, and it was needful that they should have been, some of their so-called remedies would kill ordinary people. I have had them applied to myself once or twice, but never again shall I share in the fearful joy of marsh-land specifics.

The coymen, both fen-men and marsh-men, were contented and happy in their own grave fashion, 
for their wants were few, and they could get all they wanted. They were philosophers in blue guernseys and thigh water-boots, and they were wont to say that the sky was overhead and Providence above that.

And at last when the time did come to drain, they could not belicve it would ever be done, as it was, in spite of all their prayers. When their sacred duck decoys passed away with the rest, the coymen reckoned the world would pass away too, and they would wait a little while and go with it. But when they found this did not take place so soon as they thought it would, they turned to something else for a living; ducks or no ducks, people must live, and they do, through it all.

The Mallard has free and enlightened views as to the food-supply, and flights for it. There are those that only have a superficial knowledge of the habits of fowl, gained from a certain class of works, often the mischievous, and we are sorry to say misleading, output of men who are quite ignorant of what they write about. I have seen some that wished to pose as fowlers-save the mark! - afraid to fire their own guns.

I have heard folks told that heavy fogs are the best things that can happen for duck-shooting, because the fog gets in the Mallards' eyes, above all birds that fly, "so that they flop about just like owls, and you can get them anywherc," and I kncw one to whom this was told who belicved that "the Bittern Hern (the Bittern) stuck his beak 
in a hollow rush stem, an' blowed in it like a trumpet, and that was how he boomed, for they'd sin him at it an' heard him." Oh, how our shoreshooters roared as they took down their "agermixter," for which all that valuable information had provided the funds, when the gentleman's back was turned. How kind they were to him when they saw him off, gun and all, in the morning; how each one insisted on shaking hands with him twice over, until his hand was numbed with the fervour of the clasps from their horny fists! Their kindness touched him, and he told them that he had not the least idea that they felt so kindly towards him. With his left hand, his right-hand fingers were a bit numbed, he drew from his pocket two halfcrowns-florins had not come to the front at that time-and told them to drink his health. They said farewell, and wished him luck. Then they went back, drank his health, and roared again.

It is no use trying to pass for what you are not, and never will be. From childhood the whole of my own life, sixty years of it, has been passed in the open air, by the waters and in the woods, by day and by night. I mean by this all my leisure timeplenty of it-trying to find out for my own pleasure and instruction, never for money profit, the ways and means of God's creatures in their own homes and haunts. Yes, sixty years of it, for long before I knew my letters I played with creatures that others would not touch.

How often have I stood on the fringe of a wide 
moor under the woodland oaks, after the acorns and leaves have fallen, with the drip, drip, drip of the rain, and a cold one too, making one feel damp, no matter how well clothed or shod, just to see a few couples of Wild Ducks come to feed on the fallen mast, the oak and beech mast! Where the great limbs reach out over the moor turf all the hollows are filled with water, dead leaves, and acorns; the outer shell or case gets softened after being in damp leaves and water.

It is what the moor-folks call a "dirty sort of cvening," generally uncomfortable; there is a lurid light about, what they call "a wild look o' things," and they are quite right in their definition; for a long level line of dull orange shows, and above that, bands of clouds of a dark cold grey, broken here and there by ragged fire-like flashes, as if a fierce fire was raging behind those clark cloud bands, if they would but lift and let you see it.

The hills against that line of clull orange show as grey masses. In the middle distance, where the moor valley runs, clouds of light grey mist appear, rolling up and out from the great ducal fir warren like wood-smoke from cottagers' chimneys. The warren looks like a great mass of dull indigo blue. But as we are noting this, a light creeps and spreads over the part of the moor which we are only on the extreme edge of, patiently watching, well hidden up, but very wet, looking for ducks; with no gun, only our glasses and our well-tried and trusty ash staff. This strange wild light wanders here and there; the 
dead tips of the ferns, as it passes over them, look like brazen ferns.

Slowly it passes on, over a dead flag-edged pool on the moor, that shows for a few moments like a mighty sheet of polished copper, with great masses of undefined purple shadows reflected in it. Then it vanishes, leaving behind it a cold yellowish-grey light, just enough to define near objects by, and that is all. Swit, swit, swit, swit, swit, swit, swit! sounds above us over the tops of the bare trees. It is caused by the ducks circling round on swift-beating pinions, before they drop down to feed. They have come up from the mere below.

They are satisfied with their aerial survey of all things below them, for they lower and come in, or rather down, to feed. From our damp hiding-place we can see some flickering grey shadows; these are the ducks rapidly flickering their wings in short beats to break the force of their settling. We just catch one or two more flecks of their wings, and then we can hear them at work for acorns; we are not able to see them now they are on the ground. Rustle, rustle, rustle, spatter, spatter! as their bills sift and nozzle about with the softest of "quirk, quirk, quirks!" and velvety quacks from the ducks, for there are ducks as well as Mallards feeding.

The Mallard is omnivorous; the dreaded potato disease, which is the cause of sad loss to the rustic population, is to the Mallard a gain and a luxury. Where whole fields planted with potatoes go wrong with the disease, just as they are fit to dig up, those 
that can be used for pigs are used, the others are left to complete their rotting; generally they are collected in heaps and covered with earth, for the stench from them is horrible. But the ducks have a different opinion on the matter; for they find the heaps out, work into them, and feed all the time they are allowed to clo so.

In Sussex and in the Weald numbers of old orchards exist, with trout-streams running through them; the banks are high, because the floods cut through in the winter-time, driving all before them; centuries of flood-water have made deep water-courses.

Now, although the trees are covered with moss and lichens, they bear wonderful crops of the finest fruit we have seen, the lower branches of some of the trees are bowed down and touching the grass, loaded with fruit. As there is not the least chance of all the fruit finding a market, the principal part is made into cider; we have seen wagon-loads under the trees, the fallen fruit, for it hangs until it is full ripe, as it saves some of the gathering. Naturally, after they have bcen collected in heaps for some time, preparatory to being crushed and pressed for cider, a lot of them go rotten ; the Wild Ducks find these out and feed on them, so do the Blackbirds. When the night falls, the Herons are in the stream working up the trout, and the ducks are in the orchard cider-making, as the natives term it ; that is, fcecing voraciously on the decayed fruit. They (lo not all get away again, for this weakness of theirs, leaning over to rotten apples and potatocs, 
is taken due advantage of when the time comes round.

When the season is right down moist; that is, when it rains day after day, with showers in between for a change, the furrows in those tenacious clay lands are full of water, no matter whether they be left fallow or ploughed. The ducks come and examine these for dropped corn, wheat, barley, oats, beans, and peas, also for worms, grubs, and other small unconsidered trifles. Some of them must come from off the tide, judging from their fly-lines. Sharp-nosed, silver-bellied eels and trout generally go together in these streams; the eels are better in the opinion of the rustics than the trout, and they are richer in flavour. The consequence of this is, that short night-lines are laid on the shallows where the eels like to rove, baited with a silvery minnow. A fine Mallard that comes down stream under the shelter of the high banks to do a little more cidermaking, catches sight of the minnow and pouches it at once, casting his quick eyes round to see if there is another. Not seeing one he turns to go, but something stops him. He flaps, threshes the shallow water up with his wings, and quarks in a halfchoked manner. Some one hears him, slips down the bank, breaks his neck, and pockets him, merely remarking that "it warn't a duck as he warnted, but he reckined he must put up with it jist fur once."

There are other methods of accidental capture known to us, but we shall not touch on these.

Before we leave this interesting and beautiful 
bird, good to look at and good to eat, let me first state that the proposed drainage of the fens and marshes, now nearly completed, met with great opposition, of a by no means passive nature, from those that gained their living from them by fowling and fishing in their respective seasons. The fowl were there in quantities beyond belief; but by those that lived in their haunts, tons of ducks were annually captured by comparatively small decoys. As I have the records from some of the decoymen's own books, for they were good men of business and kept very accurate accounts, my proofs are positive ones.

Quite independently of the decoying, there was the driving process, a most deadly method, for in the space of two days two thousand six hundred and forty-six ducks were taken near Spalding in Lincolnshire, but these practices were prohibited by statute in the reign of Gcorge II., so that only legitimate decoying was afterwards followed. My readers will get at the drift of the fen-dwellers' opinions on the subject fully if we quote a few verses from a ballad of the time, when the poet's power had been enlisted on their behalf. It is taken from J. M. Heathcote's Fen and Mere, written before the fens were undertaken, that is, drained.

Come, brethren of the water, and let us all assemble,

To treat upon this matter, which makes us quake and tremble;

For we shall rue it, if it be true that fens be undertaken,

And where we feed on fen and recd, they'll feed both beef and bacon.

They'll sow both beans and oats, where man yet never thought it, Where men did row in boats, ere undertakers bought it. 
But, Ceres, thou, behold us now ; let wild oats be their venture, And let the frogs and miry bogs destroy where they do enter.

Behold the great design, which they do now determine, Will make our bodies pine, a prey to crows and vermin; For they do mean all fens to drain, and waters overmaster ; All will be dry, and we must die, 'cause Essex calves want pasture.

Away with boats and rudders, farewell with boots and skatches, No need of one or t'other-men now make better matches. Stilt-makers all and tanners shall complain of this disaster; For they will make each muddy lake for Essex calves a pasture.

The feather'd fowl have wings, to fly to other nations, But we have no such things to help our transportation;

We must give place-oh, grievous case-to horned beast and cattle,

Except that we can all agree to drive them out by battle.

Wherefore let us all entreat our ancient water nurses,

'To show their power so great as t' help to drain their purses, And send us good old Captain Flood to lead us out to battle, The twopenny Jack ${ }^{1}$ with scales on 's back will drive out all the' cattle.

\section{THE COMMON WILD DUCK.}

\section{(Anas boscas.)}

MALE.-The bill reddish-yellow, tinged with green; iris brown; head and upper part of the neck deep glossy green, with a narrow white collar; lower part of neck and a portion of the breast dark chestnut; fore part of back brown; hind part of back black; scapulars grey and brown, very finely waved; wings brownish-grey; the beauty-spot, or speculum, purple and bluish-green, margined before and behind with black and white. Lower parts greyish-white, very finely waved with grey; tail

1 Small pike were sold for twopence in those days. 
feathers brownish-grey, broadly edged with white; the four middle ones curled and black. Nail on bill brown; legs and feet orange. Length, from bill to tail, twenty-four inches.

Female.-The bill greenish-grey; upper parts dusky-brown, edged with pale reddish-brown; throat whitish; lower parts greyish-yellow, spotted and streaked with darker shades. Tail feathers straight, speculum as in the male.

The nest of the common Wild Duck, which is large, and roughly made of sedges, flags, and grasses, is usually placed on the ground in a marsh, or among reeds or rushes, or even in hollows or deserted nests in trees, and very often in heather, at some considerable distance from water. It contains from six to ten eggs, a dull greenish-white in colour. The duck sits very closely, allowing herself to be almost trampled on. When she leaves then voluntarily, they are covered up by her. 


\section{CHAPTER XVII \\ THE TEAL AND GARGANEY}

Trie Teal is a handsome, sprightly, neat-looking little fowl. It frequents large splashes of fresh water fringed with sedges, reeds, alders, and dwarf willows, shallow waters suiting it best; in these it can spatter and sift for its food without the least exertion.

In the "fall," thousands of acres are under water, because the flooded rivers and streams are not able under certain conditions of wind and tide to empty themselves into tidal waters. Thus the 'arge grazing fats become, for a time, drowned lands; and when a change comes, and the great body of water is able to flow away, there remains for months afterwards a general state of "soppiness." Even in summer, the water-gripes and the broad cuts which run through are never dry; but in a flooded autumn season the "gripes" are brooks, and the cuts look like small rivers. Nothing is to be seen but miles of greygreen pastures, intersected in all directions with lines of old pollards, and old sedge and reed-beds. A dreary look-out this is, and a damp one too for the shooters, but a perfect feeding-range for Teal. 
They seem to know that they are in great request, and for that reason they feed where there is not the slightest chance of getting at them. It is not pleasant to look at-a large spring of one hundred, or it may be nearly two hundred Teal, without any chance of placing even one bird in your pocket, much less a couple. Yet such is very frequently the case. It would be all right if you could only get among them, but that is just what you are not able to do. Moreover, they are very quick on the wing, springing up and off in a very snipe-like fashion. If you do not get them at once, they are, as the saying is, "round the corner and in the next street" quick. A fair snipe shot will generally account for Teal when the chance offers, but a few couples-got by patiently trying up the gripes, and cautiously getting on the edges of covered-in pools and splashes-are a mere nothing.

Apart from their value as table birds, there is another point to be regarded, and that is the value of Teal from a bird-preserving view. Old, fullfeathered drake Teals are by no means numcrous, and before I left the moist flats, a Teal drake in all the pride of full plumage would fetch more at the bird preserver's than elsewhere. Any number of the birds can be had in all stages of plumage: but out of fifty you may not be able to pick out a drake in perfect feather. They are delicate birds, and it does not take much to kitl them. If they are hit, a snipe charge will stop them.

In hard weather they visit the tide, not from 
choice but necessity. As their larger relatives, the Mallardis, are similar in their general habits, the springs of Teal mix with them, and go with them to the decoy-ponds, leaving the greater part of their company behind. Decoys have been constructed specially for 'Teal, but duck-decoys answer the purpose very well at times, and it was from the decoys that the large numbers of Teal reached the market, where, in dealers' terms, they were called half duck. The reason of this was that a couple of Teal were considered equal to one Mallard, and were paid for as such —as half fowl-so that two Teal drakes and two ducks, that is, four half fowl, were paid for at the same price as a Mallard and duck, whole fowl. The question as to whole or half fowl constitutes a very important matter in all wild-fowl dealings, and if the matter is not distinctly understood, things do not always run quite smoothly.

lt would not, in the full sense of the word, be correct to say that Teal nest in some of the southern counties. But a few couples do nest in certain favoured spots well known to me, which, however, I shall not even indicate. One spot that I frequently visit holds Wild Duck, Teal, Woodcock, and Snipe, and, what is of more interest, they nest there in the nesting season.

It is really a wonder how the Teal duck manages to get her down-covered young ones-dark olive on the back, and ochre colour below-from her nestingplace. From the alder moor above to the lake below is a considerable toddle for the squeaking, 



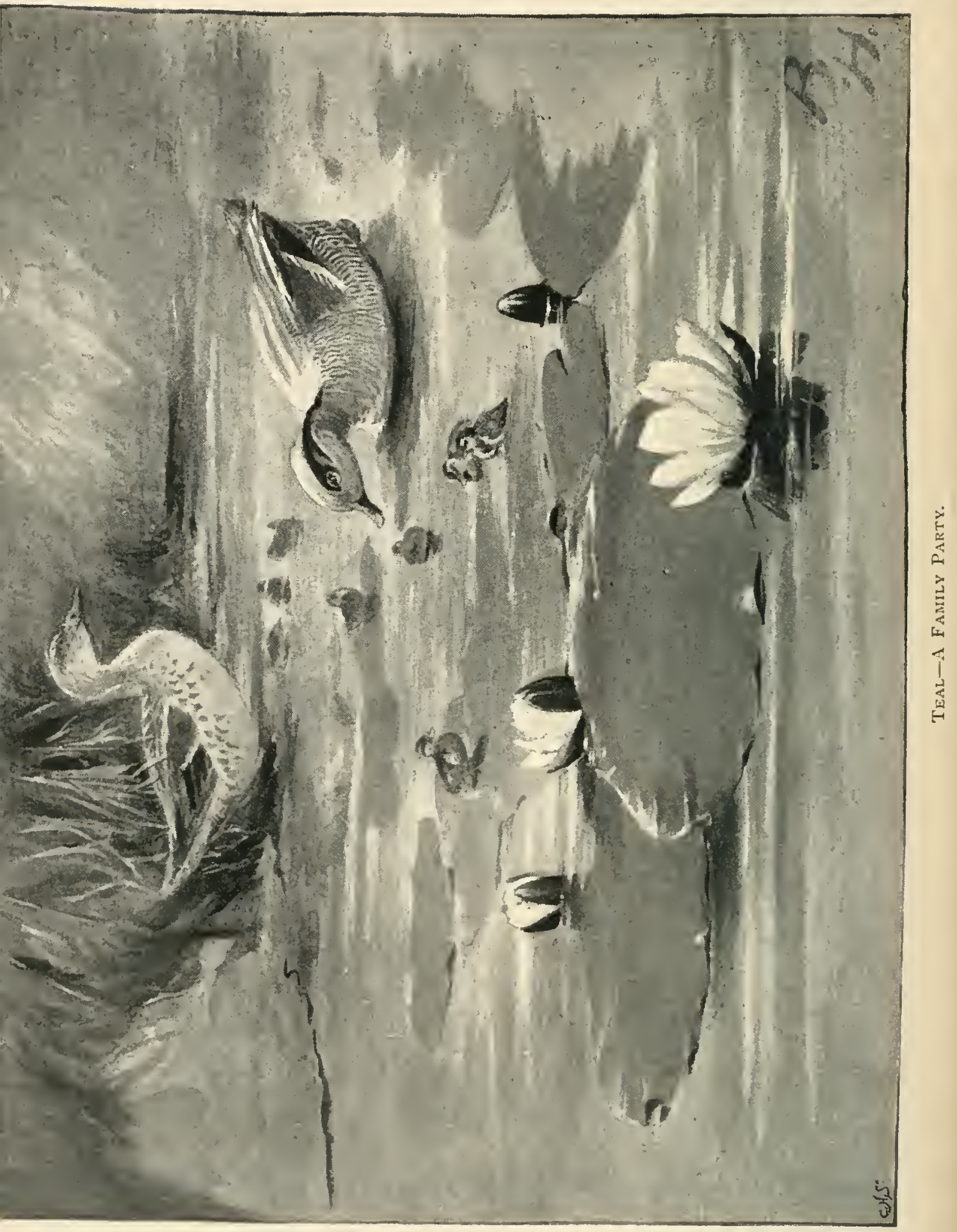


mouse-like creatures; but she manages to bring them bundling along, in any rut, drain, or cart-track, her nimble little brood following closely in her wake. If seen, as she sometimes is, no harm comes to her, it being the universal belief that those who wantonly injure innocent creatures will surely come to harm of some kind, either sooner or later.

Here is a bog covered with grass tussocks and alders, not a floating bog, but a spongy one. It is on the slope of the hill-side, and at its upper end you can get about without getting wet-footed. Close by its side runs a rough cart-track, stone-littered and heather-patched; so little, in fact, is it used, that the heather has even grown over the cart-wheel ruts. Rabbits are numerous, and that is why some object, which has come from the bog and gone into the rut some distance above, is taken to be one of these animals, and is not further noticed.

While I stand thinking about wild life in general, and nothing in particular, a faint noise very like that made by young ducks reaches my ear. What can it be? Young weasels? No, it is not their time. The noise gets nearer. Cautiously looking up a straight bit of the cart-rut, I can see a brown bird coming, and followed by what looks like a lot of mice. The bird has seen me. One or two small quacks are given, then she stretches her head and neck on the ground and flaps with her wings as much as the confined space of the rut allows her. I do not go too near, lest the little ones should hurt themselves; some of them are trying to get out of 
the rut, but they only come down on their backs, their little paddles working frantically as they try to get up again. The Teal duck is taking her brood to some small pools just below. Taking a sweep out into the heather, I re-enter the road above her, so as to leave her in peace. For a certainty, no friend of mine could interfere with a feathered family such as this.

The Garganey Teal goes also by the names of Cricket Teal, Pied Wigeon, and Summer Teal; the last name is the most suitable, as this bird is only a migrant. Any waters suitable for wading birds are also suitable for the Garganey.

The plumage is not so gay as that of the Common Teal, but the tones of colouring are beautifully arranged. A notice of this bird is given, although it very rarely finds a place in the ordinary shooter's bag. It can be had sometimes, if sought for in proper places; some quiet bay in any slow-flowing river, surrounded by oat-grass, candocks, sedges, and trailing tangle, is pretty sure to hold something; at least I have been able to find birds in such bits of river water.

A good water-spaniel does not require to have one word said to him, and what he does not know the man who carries the gun is not able to tell him. Nothing puts me out more than to see a good dog in front of a man who is not fit to carry a gun. Dogs have been rated often for having more brains than those behind, for whom they were doing their best to find birds; which when they were found were 
clean missed, the poor dogs receiving a peppering instead. Fools sometimes get at the ends of guns as well as of fishing-rods, and then men's eyes are knocked out and dogs are crippled. This is sport (save the mark!) with a vengeance.

I have had the pleasure, and I may say the honour, to shoot in the company of some of the best fowlers, not shore-shooters, of their day. No matter what got up, hare, rabbit, partridges, henfooted fowl, or web-footed fowl, due law was given, and then up went the long fowling-piece. In eight cases out of ten the creature would drop dead in its tracks.

"You shoot a hare," was said in quiet scorn to one who had not shot forward enough; "it squeals; it's murder."

The young shooter knew his man, and rested his gunstock on the toe of his boot, simply saying-

"I beg your pardon, I did not aim forward enough."

Looking at the young fellow, barely out of his teens-the man's keen grey eyes saw quite as much as most people's, and perhaps a little more-they were eyes that glittered like cold steel when he was angry - he made reply -

"All rigght, youngster ; you can kcep your 'paddy' under I see" -the lad's face was crimson, and his eyes blazing. "That's right, choke it down; it will be of use to you when you get older, for there is a little too much gunpowder in your composition, and the least thing lights it. Now I will give you a 
lesson; when the next hare gets up, you watch me."

The hares on the flats were large and roughcoated, not like the sleek-coated creatures of southern park-lands. If the weather were at all fair they would generally lie between the mole hillocks, almost between the feet of the fowlers.

One got up, going away at top speed. There was not the least hurry. "About right distance," he muttered. Then the report of his gun rattled over the flats, and that hare turned a somersault and lay dead as a stone.

When in pursuit of water-fowl that feed, as a rule, about the margins of rivers, lakes, and streams, no happy-go-lucky system will answer. They frequent certain places for food, and the first thing to do is to try and find out what that food is, and at what times they search for it, whether morning, evening, or night. Another consideration is the locality. I have put Teal and ducks up from pools close to well-used footpaths, but all the traffic was over early in the day, and of the fact the fowl were perfectly aware.

The same rule applies to fowling which applies to fishing. Keep quiet and away from the banks; crawl as much as you like and as slow as you like, but do not move any creatures from under them if you can help it, whether furred or finned; indeed it is always best to act as if certain they were there, and then you will not make blunders. All fowl which feed in or on fresh waters are sure 
to spatter and sift for food, either under the banks or round the edges of river tangle. I' Wen put up, there is only a flick and a flutter and they are gone. If you are not ready for them the fault will be your own, and you must put up with the consequence.

A Garganey may be known to frequent a certain place, but one may have to go several times before getting the bird. If a couple are settled there, you may be able to procure them, but as a rule it is only one that comes to grief, for the other shifts. What their numbers may be now in certain districts cannot be said, because it is impossible to reckon, for changes come with such rapidity that old haunts of fowl vanish almost directly the change has been decided upon.

My limited experience of the habits of the Garganey is that they are of a secretive nature when frequenting inland waters. Sometimes one or a couple will frequent a quiet bit of water close to some mansion.

"Hi, Luce!" and round the corner of the looker's house appeared one of the finest spanicls that ever a fowler would wish to look at. A beauty she was, white with liver-coloured patches, and, though that is saying a great deal, as good as she was goodlooking. The looker's wife and children were fond of her, and that was all very well when she had to be at home; but her devotion was for her master. He was a good one, and she would watch for him, and, when allowed, follow him everywhere. "No, Luce; no, my gal, you can't cum to-day. 
Go an' keep the missus an' the young 'uns comp'ny. Look at her. Damned if she ain't goin' tu cry just because I must leave her at home."

I knew Luce, short for Lucy, well. I have heard her bay out her deep bell-like tones, as she would challenge at rare intervals a strange footstep passing by the looker's house, for she was a good house guard.

"A better crittur 'an Luce was never whelped," her master has told us over and over again. "She'll find fur ye anything-woodcocks, snipes, fowl, hares, an' rabbits, an' bring 'em to ye; it don't matter where they drops or gits tu. An' she ken swim an' dive like any otter." This was high praise, but the dog deserved it all.

One day he remarked-." There's a Teal in the reed-splash o' sum sort, cricket (Garganey) or green-winged 'un (Common Teal). Hi, Luce gal, cun along."

She did not want telling, she was quite ready. Her master just indicated the reed-splash, and off she trotted a little way in front of us, turning her head from time to time to see if we were keeping close. As the splash was neared, she made a dead stop until her master had posted himself with his gun, and then she glided into the tangle of the splash. Now and then the reed-tassels would move as she quietly passed through, but not even a Tit showed itself above them; her quiet movements alarmed nothing.

Presently four or five tassels moved, bowed down, 
crossing each other, then sprang up again. "She's found," whispered the looker, with his finger touching the trigger. A few more nods and bends among the reeds, then a slight flutter, and up sprang a Teal; but it was no sooner up than down. Luce brought it to her master, wagging her tail at a rare rate. It was a fine drake Garganey.

"Luce must ha' worked him close afore he sprung, fur he dived. Look here," said the looker, as he handed me the bird, "he's wet under the wings."

\section{THE TEAL.}

\section{(Querquedula crecea.)}

MALE.-The bill is black; iris brown; head and upper part of neck chestnut brown. From the eye to the nape is a shining green oblong patch, narrowed behind, and margined in front and below with a black band and a white line. A curved band of white rises from the base of the lower mandible and passes over the eye; the feathers margining the base of the bill dusky; the throat brownish-black; on the middle of the hind-neck is a black patch. The upper parts are waved with brownish-black and whitc; the hind-part of back brownish-rrey, faintly waved; the scapulars partly grey, yellowish-white, and black. The wing coverts, primary quills, and coverts are brownish-grey ; outer secondary coverts reldishwhite towards the end. Beauty-spot velvet black, and bright green glossed with purple; upper tail 
coverts black, edged with grey; tail feathers brownish-grey, edged with paler shade. A part of the lower neck is barred in front as well as behind; the rest, with part of the breast, is yellowish-white, with roundish black spots; hind-part of breast, sides, and belly white, waved with grey. Under the tail are two cream-coloured patches and a black middle space. Legs and feet are bluish-grey, tinged with brown. The length of the bird, from bill to tail, is fourteen or fifteen inches.

Fenale.-Bill blackish-green; head light brown, with dusky streaks; back dark brown, each feather having two bands of yellowish-brown; beauty-spot velvet black and green. The neck in front is yellowish-brown, waved with darker shade; the breast white; the rest of the lower parts brownish-white, spotted with brown.

\section{THE GARGANEY TEAL.}

(Querquedula circia.)

MALE.-Bill blackish-brown; iris brown; upper part of head, and a band along the hind-neck, umber brown. A white band over the eye and along the neck; cheeks and upper part of neck chestnut brown, finely barred with white. The back dark brown, the feathers being edged with light brown. The scapulars are black, with a middle white stripe; beauty-spot dark bluish-green, margined with white; lower neck and part of the breast dark brown, with paler crescent-shaped markings. The lower parts 
are white, but the sides are marked with black waved lines, leaving two broad bands behind; legs and feet greyish-brown. Length, from bill to tail, sixteen inches.

Fearale-Smaller. Head brown, with dusky spots; over eye a brownish-white band with dusky streaks. The feathers of the upper parts are dark brown tinged with green, and have reddish-brown edges and whitish tips; wing coverts brown. The speculum or beauty-spot dull green; throat white; the fore-neck and breast grey-ish-white, marked with brown; side feathers brown, with white margins. Rest of lower parts white. 


\section{CHAPTER XVIII}

THE PINTAIL DUCK AND THE SHOVELLER

THE elegantly-formed bird which is known as the Sea Pheasant, Winter Duck, Pintail Duck, and Pintail Teal, is, as one of its local names denotes, among our winter visitors; it visits not only the inland waters but also the coast. Like the Magpie, it pays much attention to its elongated tail, which is raised when on the water, and also when the bird is on land. By some this bird has been classed with the Teals; but to me it has been, and always will be, simply the Pintail Duck.

After the weather has been very rough, a few Pintail Ducks will have come with other fowl as near to the harbour's mouth as they apparently consider prudent, and there they may be seen rising and falling like corks, now down in the hollows, now on the crests of the waves, their tails cocked up and their eyes looking exceedingly wide-awake. As to procuring a Pintail Duck at such a time, well, it would be absolute folly even to think about it.

It has been "dirty weather" for nearly a week off and on, and the fishing-boats are closely packed in 
the small harbour, anchored under bare poles. The place looks like a fir plantation with all the boughs lopped off.

If you will only go as far as the end of the quay from which the sea-wall starts, you may see the waters leaping and rushing in huge sheets of blinding spray over the sand-bar; and you will hear the roar which is none the less terrible in its sound because distance softens it. No craft belonging to the place are out to-day, and in that fact lies a consolation of which inland dwellers can form no conception. Women, married and single, are on the quay talking to one another; they can hear the hiss and roar of the bar, and with glistening eyes and lowered voices they thank God that this time their men are at home, or at least in harbour, which means much the same thing, considering that none but a native of the place could reach that haven of rest from the open sea, such a network of channels intervenes. So close is the steering that, when the ticle has gone down, the cuts of the keel in the ooze may be seen.

Hundreds of times have I watched them come in from open water, each skipper and his small crew so well known to me, and loudly were they hailed as they swept up the winding channel, darting now here, now there, for sailing water. To all appearance the skippers of those crafts which followed in each other's wake were taking matters very unconcernedly; but this was not really the case. Their kecen eyes were taking everything in, and their strong grasp on the tiller was that of long practice, 
and it humoured the crafts to the utmost. To a stranger watching them enter the harbour full speed, it would look as if by no possible chance could they help dashing into other craft already anchored. But not so. Down would come the sails like magic, out would run the anchor-chain, and they were at their moorings.

There is a time for all things, and what a man has done at twenty-two, he can hardly expect to be able to do when he is sixty, although even then some will have a good try at repeating the exploits of their youth. I have been out in all weathers, simply because I liked it, but, when one is compelled to throw oneself down on the spray-damped shingle, and to grip down in it in order to keep from being lifted over the sca-wall, the work is more than rough enough.

"What hev ye got thet gun out fur? Surcly ye ain't goin' near the mouth where the bile-up from the bar cums in, be ye? Yc wun't be sich a fool; why 'tis bubblin' an' hissin' like a copper gone mad on a washin'-day. Bide here, don't get driftin' down the mouth o' that place; all the salts is brimming up the wall."

"Well, I thought that some fow might be in the bay bend of the second channel; it is slack water there."

"Oh, well, look here. Curly Ned hev got his craft on them salts; he got her up there out o' the way, to tar her. He's aboord her, I know, and her skiff is there. But don't ye git acting the fool now. 
THE PIVTAIL DLCK AND THE SHOIELLER 223

You ought to be tarred an' feathered, you owdacious rip, you did. There, 'tis no good talking, you means going, I kin see."

Some manœuvring in the way of water dodging, and the place was reached. There was the vessel in all certainty, but apparently there was not a soul on board.

"Spanker ahoy, ahoy!" I hailed, and barely had the hail been given, when up popped a red fisherman's cap.

"What cheer, my son, what cheer! Cum aboord. This 'ere is a bit o' luck; 'tis like being marooned on a desert islan', being the only crew aboord. Tumble in. She's fairly wittled, for there's skate and dabs and 'taters, and biscuit and soft tack (bread) in the locker, an' a full Dutchman (bottle of hollands). My watch is up in the arternoon, fur dad's cumin' down then. What are ye on the cruise for ?"

"Fowl, Curly, if there is a chance; there is some about."

"Yes, there is, at the gullet o' that slack-water bay ; but 'tis risky, the water biles."

"Can I try?"

"Now look here. If I get the skiff out, will you keep watch along o' me arterwards till dad cums? for 'tis enough to give you the blues bein' alone."

"Yes, all right."

"Then out she gocs, sink or swim. Get in the bows; ye are loaded." 
I had not the least wish to see what it was like round the corner of that slack-water bay, as it was bad enough here, where the waters, covered with great patches of foam and foam-bells and dirty yellow froth, the churn of the tide, swirled round the sides of the bay. Tangled sea-wrack rose and sank again, like the hair of a drowned woman. It was not a pleasant sight. Then something hit the bottom of the skiff.

"What's that, Curly, eh?"

"On'y a bit o' drift ; look, there 'tis. It's riz up." Then for a moment what looked like a man's arm covered with wrack shot up and down before it went under again.

"What do ye think on it? Don't ye feel her shiver? I shan't go in the wash up o' the gullet. If ye gits a shot 'twill be here, for I ken jist keep her stem on. Look, what's that 'ere bobbin' up and down?"

"That's a black duck" (Scoter).

"Not that thing, t'other,"-they were Pintails. "I'll drive her a bit nearer. Can't get so werry much closer, else we'll be in the ruck o' the bile-up. Now, watch yer chance, git on 'em if yer ken, fur the tide will bring them to us. Can't git her no closer, an' can't keep her no stiddier."

Once, twice, the gun was raised, and the finger almost pulled the trigger; but there was a boil-up of the waters, and great masses of foam and tangle hid the birds.

"Why don't ye pull? Can't keep her head on 
like this much longer, for I can feel the back set o' the tide wobblin'. Let go, hit or miss."

Once more I aimed, and pulled. Just as the trigger was pressed the skiff rose, and so did the P'intails. I had shot over them; a clean miss it was.

"What luck?"

"None."

The way that skiff swung round and reached shore at racing speed was a caution. Some people write about fowling as if it were bird-slaughter. If they had known what it is to feel a skiff or punt quiver under one, and to have to clench one's teeth to keep them from chattering, they might have written differently on fowling matters. Imagination is a very good horse to ride, if kept under control; but when he takes the bit between his teeth and runs away with his ricler, the spectacle affords sometimes a considerable amount of fun for those who look on.

That handsome duck, the Shoveller, frequents the marshes and lagoons. Its large bill is formed for sifting, spattering, and surface-skimming; and shallow waters with plenty of cover are necessary for its well-doing. It has been taken in the decoys during hard weather, as then various species will mix up, that is, they will for a time follow other fowl in their fly-lines in order to procure food, knowing that when fowl go regularly in a certain direction, at certain times, food is what they go there for.

Compared with the size of the Shoveller's weak 
paddles, its webs are small. Splashes and reed-beds are what it delights in. Many days have I passed where these birds could be seen, catching the great green grasshoppers, and getting my fingers pinched over it, digging out crickets, and chasing Swallowtail and other butterflies in and out of the tangles. All sorts of flying and creeping things lived there; in fact the amount of insect life to be found in the haunts of the Shoveller would have to be seen, nay, more than that, it would have to be felt, before it could be thoroughly believed in. Some kinds of insects have a very short play-time. Coming forth in clouds as perfect flying creatures, they fulfil the purpose they were created for, and then they drop down in the reeds or on the water, either dead or dying. So thickly at times do these shortlived insects cover the water that, in places, the masses look like large patches of grey film.

This is the time for the Shoveller. He and his mate will, so to speak, lay their heads and necks on the water, the lower mandible being just under water; and they will paddle along, feeding as they go. These insects are part of their food in the season. Then, too, they can probe and spatter on the edge of the reeds, where they find plenty of food, for the soft mud at their roots is full of the seeds of water-plants growing below. As to the undeveloped forms of insect life, the light vegetable mud is full of these. So this handsome fowl goes on his way very happily if not disturbed; and the Shovellers were not disturbed in one particular 
haunt of theirs within a few hundred yards of the 'coy.

At times, like all other fowl, they flighted, and then it was that a few pairs would come in with the ducks and be captured. If fowl once get to know that they are secure from interruption and noise, it will take a lot of decoying to make them at all shy. However, there is a medium in all things. Shovellers are plump ducks, and when their food is right are excellent for the table.

\section{THE PINTAIL DUCK.}

(Dafila acuta.)

MaLE.-Bill black, but the sides under the nostrils are pale blue; iris of a reddish-orange; head and throat dusky brown. On the hind-neck is a lengthened band of greenish-black, and two white bands following to the white of the lower parts. Back and sides finely waved with grey and white; the lesser wing coverts grey. Beauty-spot, which is green and black, is margined in front with red, and behind with white. The long scapulars velvet black, edged towards the end with yellowish-white. Primary quills and coverts are light greyish-brown, with: white shafts. The belly white, faintly waved with grey. Tail feathers are grey, edged with yellowish-white, the tint getting deeper towards the two middle feathers, which are brownish-black; legs and feet greyish-black. Length, from bill to t.uil, twenty-five inches.

F camle-Smaller. Bill greyish-black abore, red 
brown below; head and neck light red brown, with dusky streaks. Upper parts are very dark brown, the feathers being edged and barred with reddish-white; the lower parts reddish-white, with dusky spots.

\section{THE SHOVELLER.}

(Spatula clypeata.)

MaLE.-Bill black, with a tinge of grey; iris orange. Head and upper half of neck glossy green, the top of the head being purple. Fore-part of cheeks and throat black, slightly glossed with green; the rest of the neck and small part of the breast white. Back greenish-black, the feathers on front part margined with white, while behind they are darker and more glossed with green. The tail coverts very bright; tail feathers brownish-grey, margined with white; the scapulars white, greenish-black, and pale blue; the speculum bright green, margined in front with white. Small wing coverts light blue; the primary coverts and quills brownishblack, shaded with grey, the shafts being white. The breast, sides, and part of the belly are deep chestnut, with a purple tinge; legs and feet orange. The length, from bill to tail, is twenty inches.

FeMale.-The bill is dusky above, reddish-brown beneath. Head and upper neck pale reddish, with dusky streaks; lower neck and breast similar, with dusky spots. Upper parts blackish-brown, the feathers edged with reddish-white; the smaller wing coverts tinged with light blue; the speculum smaller and duller in tint than that of the male. 


\section{CHAPTER XIX}

MORE OF THE WILD DUCK FAIILY

Tife stoutly-built little duck, the Tufted Duck, is a migrant. At one time within my recollection, this bird was fairly well distributed in localities suited to its habits. I cannot say whether at the present time this is still the case; but one thing is certain, Suffolk and Norfolk still hold the Tufted Duck. These counties have water-ways and other waters which are highly favourable to the species of duck now under consideration; and they have another advantage besides, and that is the protection given to the fowl on the princely estates in this part of England.

Like all other diving ducks which get the principal part of their food from more or less fresh waters, the Tufted Ducks do not seem to observe any hard-and-fast rules in such a matter. In hard weather they visit the tide or tidal waters, and they are compelled to visit salt waters when the ice binds up all others. From what I was told by a Norfolk fowler, a man who was well acquainted with fowl 
on the tide, Tufted Ducks must be numerous at certain seasons. They consisted principally of females and young birds; at least he had met with these in considerable numbers, and very wide-awake, he said, they were.

Numbers of fowl not generally supposed to breed in this country do nevertheless breed in Norfolk and Suffolk, where protection is afforded them. It is quite probable, therefore, that those gatherings of "Tufts" may have consisted of home-bred birds, as, when they are forced to the tide, they have not far to go. It is to my mind a fortunate thing that places can still be found where such a bird as this, which has been briefly noticed, can find itself a nesting-place. Reeds, and that lush-water vegetation which is only to be found in waters where they have been left as nature placed them, suit water-fowl. What they like are not the mere patches of reed, but reed thickets, extending for mile after mile, the reed-ponds of our eastern counties.

The Gadwall is a plump-looking bird. At a distance it might easily be taken for a farm-yard duck, owing to the general soberness of its plumage. Gadwall Teal, and Grey are names that it is known by, and very appropriate is that last-mentioned name, for the bird looks grey. The last Gadwall that I examined, away from what might be thought its proper haunts, was one which had been shot in a reed and flag-fringed bay of the river Mole, early in the spring. The bird was shot not two hundred 


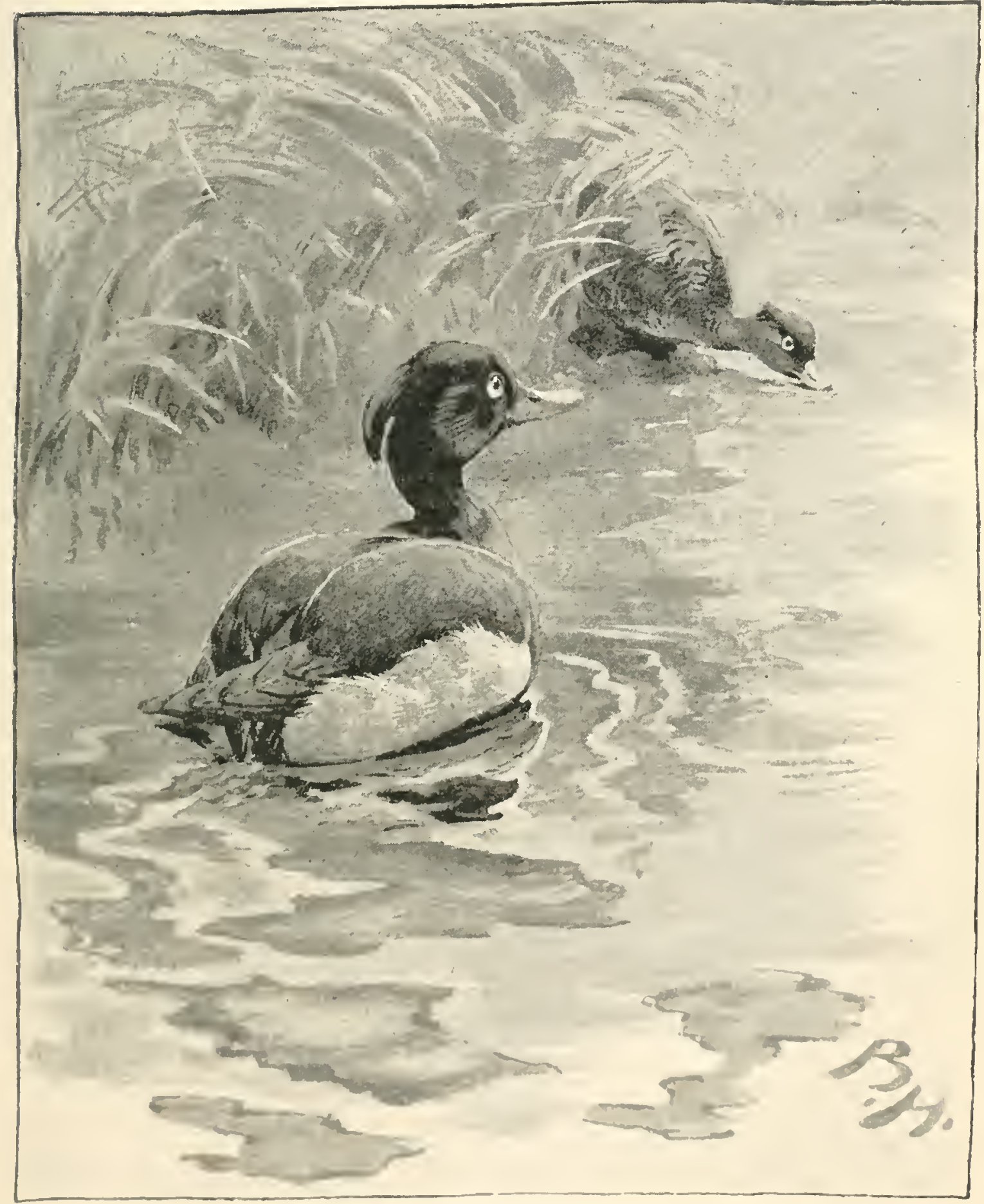

Titril) Duck 

yards from where I was standing at the time, and it was brought to me to be identified; there could not, therefore, be any mistake possible as to its species. It was a solitary bird, and no companion to it was seen above or below the place on the river where it was shot.

Sometimes this bird is captured with other fowl in the decoys. One peculiarity of the plumage of the Gadwall or Grey Duck is that delicate, halfmoon-shaped markings are on the breast. It is far more alert and nimble in its movements than any tame duck of the farm-yard breed, but the resemblance is nevertheless so close at quite a short distance, that ordinary shooters, keen as some of them are, have passed them sometimes, thinking them to be domesticated ducks. Such a mistake as this does not take place very often, owing not only to the fact that the Gadwall is what may be called an uncommon bird, but also to its shyness.

Although this bird is a surface feeder, and not strictly speaking a diving duck, I have placed it after the 'Tufted Duck, because Norfolk is at the present time its great haunt. In one part of this county, within quite a short time back-six, or it may be seven years ago-Gadwalls could be found in great numbers, as they nested there, owing entirely to the protection they received. Unless some great and sudden change has taken place of which I have not heard, no doubt the birds are now far more numerous than they were a few ycars ago. By griving protection to the fowl, we should get them 
nearly all back again. Those that have been almost exterminated would increase their numbers, if let alone; and those which have been killed off completely would be replaced by others of the same species from those countries whence at rare intervals they do occasionally arrive, without being allowed to remain here. Legitimate sport does not exterminate fowl. If such shy birds as the Tuft and Gadwall can be got to stay and breed, other fowl would do the same in other localities; but at present Norfolk and Suffolk are rare instances of what protection will do for those birds which are elsewhere so scarce.

That black-and-white visitor to our shores, the Golden-Eye, has had many names given to it, differing according to the various states of plumage in which it happens to have been procured. Magpie Diver is the name for the bird when in full plumage, and it is also called Whistler, Golden-eyed Duck, Golden-Eye, Pied Wigeon, Gowdy Duck, Morillon, and Rattle-Wings, the last name having been bestowed on the birds because when in flight their small, sharp-pointed, stiff wings cut the air with a very peculiar whistling sound. Morillon, or, as is sometimes said, Morillons, is the name now given to young birds which were at one time considered to belong to a different species.

The Golden-Eyes are very active in all their movements on the water; they swim very rapidly, and will dive at the flash of the gun, escaping the shot sometimes, although by no means invariably. On 
land they are, as one of my friends remarked, "not quite so slippy." My own acquaintance with this handsome fowl was made in the creeks rumning up from open water; but since that time I have seen specimens which had been procured well inland. As the Golden-Eyes are now known to have a preference for fresh waters in certain localities, their appearance, one at a time as a rule, on secluded pieces of water, fringed round with heather and sheltered by fir trees, is not to be wondered at. Why they should have becn so eagerly sought for by all the gunners of my native fore-shores I never knew; and I am quite certain that now I never shall know the reason. But they were thought a great deal of, and if one of the lads brought the news up " thet one o' them Magpie Divers was in the crick," there was sure to be a general adjournment of the shooting members of the community, as each man would slope off uncler some pretext or other with the intention of trying to get the bird.

That rare bird the Buffle-headed Duck, also called the Marionette, Spirit Duck, and Harlequin (because of the extreme rapidity of its movements), is smaller than the Golden-Eye, measuring only fifteen inches from bill to tail. The general arrangement of the plumage is in black and white, with deep green and purple reflections. This was the "little Magpie I)iver" of the shooters and fishermen. I know that he is now considered to be an extremely rare bird; but judging by the above homely title, 1 think the men must have noticed it in past years; 
though, to those afloat, fishing was of far more interest than all the fowl. Only those fowl which could be eaten were tried for, just for the sake of sometimes varying a very limited diet. If a bird had the bad name of being "a fishy one," powder and shot would not be wasted on him. Although the shooters might know that a Harlequin was about, yet, so far as they were concerned, it would not pay to go in pursuit of it, for it was very certain that all chances would be in favour of the little Magpie Diver. Drake Golden-Eyes in full black-and-white livery I have seen shot, but never at any time the Harlequin. At one time vast quantities of fowl used to gather where small fish were captured for manure only; tons on tons of fish, which greatly attracted the fowl. Sometimes, as might naturally have been expected, a few birds would get meshed in the act of diving, but not very often did such accidents take place, as the whole lot were very wide-awake. As the natural history system of the present day is carried on in a very different manner to that of the past, things get much more sharply looked into. One matter is very certain, there are not now so many fowl to look at; and if, among the number there once were, this bird had not been seen and noticed by the fishers, it would not have had that title of Magpie Diver given to it.

The Long-tailed Hareld, a handsome and stoutlybuilt sea-cluck, is a northern visitor. It has been so well described, from the life, by late writers, that little is left to be said about it. Its curious 
cries and actions have attracted the attention of all who have met with it. Men whom I knew in earlier years, who had sailed in the staunch old luggers, used to call these birds North Sea Ducks. As the luggers were often far from land, in rough weather, for rarious purposes, and in hard, dead winter, their crews frequently saw the North Sea Ducks rising up and sinking with the waves like corks. It must be desperate weather that will drive this bird inshore for food and shelter.

Now and then a specimen would be brought home for one of the local bird preservers; and this, when known to be in the window, would cause quite a sensation in the place, and there would be considerable gatherings of spectators off and on for some little time. Some of the lads knew the history of all the web-footed fowl in the windows, so far as the taking of them was concerned. They could tell how the birds were got, and when; for their fathers had procured them.

That heavily-built duck, the Black Scoter, visits us in the autumn, and leaves our shores for breeding purposes. Some are scen throughout the year, but they are not nesting birds. Where the shores are favourable to the growth of shell fish, there you will see Scoters on the water. They are very sociable in their habits; large flocks of them can be scen in favourable localities. But there are exceptions, and I have seen solitary members of this species diving. without a fowl of any kind to be seen anywhere near. They are called Black Ducks on the coast, 
and the name is a very good one for them, as, although not a scientific (sic), it is a comprehensive one.

As fowl for eating, they can only be described as fishy abominations. On the tide they are most interesting studies of diving bird life. Harmless pranks have been played on unsophisticated people in the way of offering them gifts of wild-fowl, but never did I know of an instance when a Black Scoter formed one of the bunch. There is a line drawn about some things even on the fore-shores, and in my day it was never passed where the bird now under notice was concerned. Now and then the local bird preservers would set one up, but, as they said in their forcible though homely fashion, "they didn't hanker after them."

For a month it has been freezing hard without break; not even one day of soft wind have we had. Now that the tide is out, the beach, up to watermark, is glistening with ice. The piles that run out from the fore-shore look weird, as ice has formed on the heavy sea-weed tangles that cling to rotting piles. They look as if hung with great ice-clubs, for the clrooping weed masses are thicker at the bottom than they are at the upper ends, where their roots are fixed in the rotting wood. It is a curious sight to look on one of those club-shaped icicles when winkles, crabs, and small fish that have taken refuge there are frozen in the weed tangle. Bitter as the weather is, there has not been a rough tide in the whole course of the month. As the fishers 
said, "the hard weather had killed the tide for a time, the sky was bluc as a razor above in the daytime, an' dark as a jersey at night. All the time things kept like that, ticles would be casy." And as usual they were quite right in their weather forccast.

Those who know the sands as only coast folks can know them, are able to travel with safety over them, even if to casual observers they appear frozen when the tide is out. Black Ducks are on the water, in a line with the lightship. So great are their numbers, that when at times they rise, they look from the beach like a small patch of dark cloud. To reach the water-line, that is to say, the utmost limit that the tide ever ebbs down to, would not be accomplished by making a straight line in its dircction, although, to all outward appearance, the sands look as if you could gallop a horse over them. Having had varied experiences here of a practical, but by no means pleasant nature, I take a long "rake" out of my right course, and come in close to the ticle on winkle hards, not sand. One great stretch of sand, level as a billiard-table-at least, so it looks from the distance-I do not even glance at to-day. If I did, I should see bits of timber-not rery big, for they will soon be fit to burn as fire-drift, without cither sawing or splitting-sticking up and bulging out of that bit of all-boiling quicksand. Those who rommed the beach in all weathers, scarching for flotsam and jetsam even in dead winter becaluse they had nothing better to do, said that "no livin' 
bein' knowed what them quicks had got smothered in 'em, nor yet what the tides would root out of 'em." The speakers were not beach-combers, or wreckers; such vermin never existed on my own fore-shores. These men were the first and foremost of those who tried to save life if they could, when the distress flag was flying. or the boom of the signal-gun was heard, and they were grieved when their efforts proved of no avail.

Boards, firmly fixed in the beach shingle, and with inscriptions beautifully written on them by the same skilled hand which wrote the new tablets of the Ten Commandments in the old church, fair and plain for all to see and read, explained the rights of the Lord of the Fore-shores. These rights were never claimed in my days on the tide; I do not go so far as to say they never had any real legal existence, I merely state that, such as the rights then were, they were not claimed. The "perwentive men" looked after the spirituous flotsam and jetsam which might come ashore by deep intention or by sheer accident, as anchored tubs would not always keep their grappling ground in a storm. The whole lot smuggled, big and little, rich and poor, whenever the chance offered, her Gracious Majesty's revenue officers excepted. Such things are of course not supposed to be done at the present day.

The only time that I ever heard the rights of the fore-shore mentioned, was when liquor in some shape or way was washed up. Any man-or, for the matter of that, any lad-was free to shoot unques- 
tioned, from the boundary of the sea-wall over the saltings to the lowest ebb of the tide. The marshes that the sea-wall protected were, so to speak, private property, and this fact was known and respected. On the beach itself you could shoot unquestioned from highest water-mark to lowest tide, and over the tide. The marsh laws were strict ones, and, if necessary, they were fought out. Not that in all cases might was right, or even that right invariably proved to be might, but all who wilfully trespassed on the marshes knew what they would have to put up with if caught without a permit to be there. It was exactly the same with the oyster-beds, or, as they were called, oystcr-grounds. There they were, and there they could be seen at low tide, but they were only there for their owners. One who did not know better-at least he said he did not when he found himself captured-gained the knowledge of what sea-boots leather tasted like, before his captors parted with him. As I saw that sea-boots performance through from beginning to end, I can safely say that, if my eyesight can at all be trusted, it must have been a very powerful and convincing performance, though scarcely plcasant for all who wcre concerned in it.

With the two exceptions I have mentioned of the marshes and the oyster-grounds, the whole of the beach and fore-shores beyond the sea-wall boundary was free to the shore-shooters for a range extending from Romney Marsh to within a short distance of London town. All this is now altered, or rather 
it may be said that certain people are trying to alter it. I have seen some account of this in the public papers; but all I can say is, that such a state of things would have been considered utterly impossible in the days when I fowled on and by the tide. In fact, at that time it would have been an impossibility for one man to deny another the rights of the fore-shores, as these rights had been in full use for a period which could not be reckoned, beyond the memories of the oldest men.

As the Lord of the Fore-shores had a right to fix notice-boards on his own behalf, there must have been also other common rights which belonged to the people on the fore-shores, and certain matters "pertaining thereto" which were their own, or they would not have been allowed to exercise such rights for so long a period. The more so as the Lords of Manors and Fore-shores in past times were apt to assert the difference between their rights and views of what they thought to be their rights, and the rights and opinions of others, in a somewhat highhanded manner.

This little digression over, let us return to our Scoters, or Black Ducks; there they are, diving and chasing each other. It is bitterly cold, and the sea is quite calm, as smooth as a mill-pond. The birds appear to be within shot, but it would be a delusion to think them so; a rifle might reach them, but they are out of all duck-gun range; and this is owing to the intensely dry and rarefied state of the air. As to the sky above, it is of such a hard, steely blue 
that it gives you the shivers to look up at it. The ducks are, to my certain knowledge, over capital feeding-grounds, as the greater part of the shell-fish of various kinds that are used for manure in the great upland fields are dredged for just where they now are. It is a long way from this bleak fore-shore to fir and heather, but somehow the Scoters, when they rise, remind me of the Black Grouse.

There is a very old but very true saying, that time and tide wait for no man, and indeed my observations are here brought to a rapid close, for suddenly I notice that the tide has turned. That is quite enough to induce me to make for the beach at top speed; but I do not lose sight of the Scoters, as they come in with the tide, feeding while they float in with, it. Fowl are capricious in their movements, or perhaps it would be more just to say that they appear to be so to those who watch them gathering in great numbers, under certain atmospheric influences, and when things alter a bit, going off again no man knoweth whither. As the fowls may be supposed to know their own minds, while those who watch them cannot fathom their secret, many of their movements and actions at times remain to us a mystery.

When I reached a bend in the shore, I met a shooter, who told me that the Black Scoters were quite as numerous, although more scattered, under the garrison and dockyard walls. He only wished, he said, that they were Black Creese (or Brents), as Blick Ducks were no good, "nut worth powder and 
shot." Not because I doubted his word, but simply to gratify my own curiosity, I made my way past Garrison Point to the Camber, where the Admiral's flag-ship, H.M.S. Queen, was stationed. A little way out, and abreast of it, there lay a mighty threedecker, carrying one hundred and twenty guns. Those sailing, first-rate ships of the line were as grand a sight as an Englishman could possibly look upon, and I have lived to see them pass from our navy. A case of necessity it may have been, but men now living who have seen them, and perhaps wondered when they were children at the glorious sight-who have, it might almost be said, taken in with their mother's milk the histories and traditions of those famous fighting ships, miss them now that they are gone from the seas. "Brown Bess" has given place to the modern rifle, with all the latest improvements, and the old wooden men-o'-war ships are replaced by ironclad Thunderers and Devastations.

There were the Black Ducks, numbers of them, round about the shipping. Ships in harbour, if the coast is at all favourable for fowl, generally have a few gather about them for the sake of the refuse or slush that is shot into the tide. Some fowl were sure to be about, on account of the refuse food from the different messes that was sent overboard. Gulls prove very constant visitors, beating about all day long, and in all sorts of weather. But their reasons are obvious. When the Scoters come in, as I saw them that day, the true reason of their 
arrival is known to themselves alone, and mere conjectures on the matter are of no use, even for a moment.

The Velvet Scoters visit us at the latter end of autumn, and leave us again in the spring. In their general habits they are like the Common Black Scoters. I have seen statements, founded on observations made in past times, that they gathered in vast numbers on the northern coasts of our islands fifty-three years ago, but if such is still the case I am unable to say. From what information I have been able to gather, I think that the Velvet Scoters are not quite so numerous in certain old haunts as they once were.

This bird, if it was seen flying inland, might at the first glance be very easily taken for a Blackcock in full plumage, the white patch on the wing adding wonderfully to the general resemblance to that bird when on flight. As a feathered curiosity, the Velvet Scoter is sometimes in request; but for eating it is no better than its common relative, the Black Scoter. It is caught in nets very often, and goes for preserving.

There is a third species of Scoter, the Surf Duck or Great-billed Scoter, which belongs to the eastern coasts of North America. From thence, and no doubt from other cold regions also, the few specimens (properly authenticated specimens I mean) which have been procured on the coasts of the United Kingrom have presumably found their way to us, some of them to be shot, and one or two to be picked up. 
Not that much importance is to be attached to very, very rare British specimens, so called. Some birds I have been asked to look at have had mysterious histories, but of course I did not say so to their owners, who had paid for the birds and were happy in their possession; it was not my place to rudely enlighten them. One thing is certain, if rare birds are wanted they generally arrive in this country by some means or other, whether alive or dead. Not for one single moment do I wish to give any of my readers the impression that genuine, rare specimens of birds shot in the British Islands cannot be found. They can be found. But there are tricks in all trades, and that of providing natural history specimens for collectors is no exception to the general rule.

That heavily-built sea-duck, the Common Eider, is abundant in northern lands; in Iceland, for instance, and Labrador, Sweden, and Norway. It is fairly numerous along the shores of Scotland, among the Hebrides, Orkney Islands, the island of Shetland, and the Outer Hebrides; and, nearer home, they frequent the Bass Rock and the Fern, or, as they are more often called, the Farne Islands, where they breed, having at one time been protected in the nesting season through coast laws which, although not legislative ones, were effectual protection to the Eider in her breeding season, the birds being looked upon as half-domesticated fowl. I am not able to state whether such is now the case, as matters have changed in all directions of late years. There is 
nothing remarkable in the tameness of the sitting duck. Not only Eiders, but other birds of naturally wild and suspicious nature, have allowed themselves to be lifted off their nests, and placed back again when hatching out their eggs.

A pair of these birds make a very good show in a glass case if well set up. Specimens for preserving are generally shot on open waters far out at sea, by those who hire the stout North Sea boats for fowling on the tide in rough weather. With the eider-down question I have nothing to do, beyond hazarding the remark that if all the so-called quilts advertised for the benefit of a shivering public are eicler-down, the birds must grow it on their bodies in immense quantities. The swallowing capacity of the Eider is something to wonder at, especially if the bird happens to have been shot after a full feed of crabs and other small fry. As fowl are generally carried head downwards because the feet are so convenient for gripping, the cargo they have packed breaks bulk again. From the nature of their food they are not particularly sought after as birds for the table.

When the young Eiders are on the water, their mother's chicf care is to watch for the Black-backed Gulls of both species; not, however, that the greater and lesser Cobs persecute the Eiders more than other fowl. I have seen some of their work; size is not of the least consequence to them, as all young birts are sure to be tender. The young of all coast birds, and sometimes the parents themselves, suffer from 
those black-backed killers. Either they get knocked off by the Gulls' wings, when sitting out on the rock-ledges, and followed down by their oppressor to where they may fall, or else they are killed and eaten at their very nesting-places. Now the young Cobs may chance to come to grief-but not, I think, very often-from the interference of feathered enemies. It seems a fortunate thing for the diving ducks that such rapacious birds as the Gulls are not able to dive. They can only float about, or, as one might say, paddle on the water, light as corks.

Thirty-nine years ago, a female Eider was shot on a Surrey moor, having been driven that way by a fierce gale of wind; and in I893 I saw a Puffin picked up alive in the same district.

\section{THE TUFTED DUCK.}

\section{(Fuligula cristata)}

MaLe. - The bill light greyish-blue; the nail black; iris bright yellow. Head and upper part of neck black, with purple and green reflections. The general colour of the upper parts is blackish-brown, sprinkled with minute white dots. The breast and sides are white; a portion of the belly is greyishwhite, mottled with dusky, in waved lines. The hindpart of the belly and the lower tail coverts are brownish-black, and there is a white band on the wing. Legs and feet are bluish-grey, and the webs dusky. The length, from bill to tail, is seventeen inches. 
Female.-Smaller than the male, but coloured in a similar manner.

\section{THE GADWALL.}

\section{(Anas strepera.)}

MaLE. - The bill black, tinged towards the base with bluish-grey; iris red brown. Upper part of head and nape dusky, with small red brown markings. Lower neck all round, and part of back, dusky, with semi-circular white lines; middle of back, scapulars, and sides finely waved with dusky grey and reddishwhite. Smaller wing coverts grey, barred with pale reddish; middle coverts deep chestnut red. The speculum, or beauty-spot, black and white; hind-part of back and tail coverts bluish-black; tail grey; legs and feet orange, the webs darker. Length, from bill to end of tail, twenty-one inches.

FEMALE. - Upper part of the head dusky, with a lightish streak over the eye. The upper parts blackish-brown, the feathers edged with reddish. The lower parts reddish, marked with grey.

\section{THE GOLDEN-EYE.}

\section{(Clangula staucion.)}

MALE. - The bill black; iris ycllow. The head and upper neck deep glossy green, with rich purple reflections. A large white spot on each side between the cheeks and the bill, below the level of the ey.e. The back and some of the scapulars are black; the outer scapulars white, with black margins; tail dark 
brown, tinged with grey. The lower neck all round, the breast, fore-part of belly, sides, and lower tail coverts white. Wings black, with a large white patch which includes several of the small coverts, secondary coverts, and some of the secondary quills. Legs and feet orange yellow, the webs being dusky. Length, from bill to tail, nineteen inches.

Feanae. - Bill brown; head and upper neck dull reddish-brown; the lower neck grey. Upper parts dark grey behind, lighter in front; lower parts white, with the sides and part of the belly brownish-grey. Legs and feet brownish-yellow. Length, from bill to tail, sixteen inches.

\section{LONG-TAILED HARELD.}

\section{(Harelda glacialis.)}

MALE.-Bill black at base, red towards the end, the red tinged with lake; the nail black. Head and neck white; the cheeks grey; a black-and-brown patch on each side of the neck. The fore-part of the breast, back, wing coverts, and lengthened tail feathers blackish-brown; quills dark brown; scapulars and lower parts white. Tail feathers chiefly white, middle tail feathers slightly turned up. Legs and feet yellow; membranes dusky. Length, from bill to tail, twenty-five inches.

Female. - Bill blue grey; iris yellow. Head and nape chocolate brown; throat a lighter brown. Sides of head and neck, band over the eye, and part of hind-neck greyish-white; a brown patch 
behind the cheek. All the upper parts chocolate brown of a greyish cast. On lower part of neck all round the feathers are grey brown, with paler edges. Lower parts white, with part of the sides grey brown. Legs and feet grey green. Length, from bill to tail, sixteen inches.

THE BLACK SCOTER.

(Edemia migra.)

MALE. - Bill black, with a patch of orange yellow on the upper mandible. Upper plumage deep black, tinged with green; lower parts brownish-black. Iris dusky; legs and feet brownish-black; the membranes darker. Length, from bill to tail, nineteen inches.

Frials-Bill dusky; upper parts sooty brown; sides of head and neck paler. The lower part of the neck, the breast, and the belly greyish-brown. Length, from bill to tail, eighteen inches.

\section{THE VELVET SCOTER.}

\section{(OEdemia fusca.)}

M.ıL:-The prominence on the upper basal part of the bill, the nostrils, part of the lateral prominences, the margins of the upper mandible, and a streak on each side of the nail black. The sides rich orange; the nail and part of the ridge reddish flesh colour; basal half of lower mandible black. the rest lake red. The general plumage black, with 
violet reflections on the head and neck, and, on the back, green and blue; on the wing is a large patch of white. The legs and feet are richly coloured with rich orange and lake; webs brownishblack. Iris greyish-white, with a dusky outside ring. Length, from bill to tail, twenty-one inches.

FEMALE. - The basal prominences less in size. General colour of upper parts brownish-black; lower parts lighter. Legs and feet like the male, but duller. A patch of white on the wing. Length, twenty-one inches.

\section{THE SURF SCOTER.}

(Edemia perspicillata.)

Male. - The upper mandible is orange red, with the nail greyish-yellow; on the protuberance of each side at the base a large square patch of black, margined with orange red, except in front, where there is a patch of greyish-white; the lower mandible flesh-coloured. On the top of the head is a roundish patch of white; on the hind-neck a larger lengthened patch of the same. Upper plumage deep black, glossed with blue, lighter below; iris yellowish-white; legs and feet orange red, webs dusky. Length, from bill to tail, twenty inches.

Female. - The base of the bill less protuberant; colour, greenish-black. General colour of plumage brownish-black above, lighter below. Legs and feet yellowish-orange. Length, from bill to tail, nineteen inches. 


\section{THE EIDER DUCK.}

(Somateria mollissima.)

Male.-Frontal angles of bill narrow, fleshy, and slightly elevated. The rough basal part of the upper mandible is oil green, the rest bluish-grey, with a tinge of green; the nail yellowish-grey; iris deep brown. Head black above, with a middle white band; hind-part of cheeks and nape pale green ; fore-neck cream-coloured. Hind-neck, back, scapulars, smaller wing coverts, and inner secondary quills white; breast, sides, belly, and rump black; feet oil green; membranes pale greenish-brown. Length, from bill to end of tail, twenty-six inches.

Ferale.-Head and neck pale reddish-brown, streaked with dusky; upper parts dark brown, marked with light red; lower parts reddish brown, with dusky markings. Length, to end of tail, twenty-four inches. 


\section{CHAPTER XX}

THE GOOSANDER AND THE PIED SMEW

That fine, handsome bird, the Buff-breasted Goosander, which is also known as the Dun Diver, Saw-Bill, and Jack-Saw, was found breeding in the year 1840 beside some of the larger lakes of the northern isles. It has also been found occasionally by the sea, one locality being near Loch Maddy in North Uist. This bird reaches us from other countries in October, or early in November, and returns northwards by the end of April.

Saw-Bill is a good name for this Goosander, as a fish, when once caught by it, has not the smallest chance of escape, and might just as well be in a pike's mouth. Sea-fowl follow their food-supplies, and distance never wearies them, because the water alone, that is to say, the set of the currents, carries them hundreds of miles without their finding the necessity for even once rising on the wing. Their food teems on all sides of them, the surface of the waters boiling up with fish which are just the right size for their gullets. As one of my fisher friends remarked, "The waters stink alive with fish o' one 252 
sort an' t'other" ; and this is during the winter months, when the fowl visit us. So very surely do the fish-eating divers indicate the presence of vast shoals of finny wealth, that the boats make for where they are at work, the fishers knowing that by so doing they are certain to get rare hauls.

Only those who have had the good fortune to witness such sights can answer as to how close, how very close, divers of all kinds will come to the fishingboats on some of the secluded parts of the coast which are still left to us. The muck-that is, what in the opinion of the crew are worthless fish-is tossed overboard in great heaps. That is the time to see the fowl come for the net shakings or scourings; food is there for them merely for the picking up, they have not got to work for it. I have seen these Buff-breasted Goosanders brought in by the boats, but young birds and females were far more numerous among them than the full-plumaged drakes. Even these, however, were not considered rarities.

There is one very great mistake which is frequently made by those who at the present time go after fowl, and that is, the infuences of weather and the question of what the birds feed on are not matters which are very much thought about; and it is of course necessary that they should be considered. The fowl are driven to some places much against their will, but leave them again as soon as they can. There is not the least reason to fear the extermination of wild-fowl. Days have been spent by a man who had no one to control or hinder him in the fruitless 
attempt to get on close terms with a full-plumaged drake, but all to no purpose. Two days after the attempt had been given up as hopeless, that very same bird got itself meshed in a fishing-net in the most obliging manner and was drowned. When the net was hauled in "he cum aboord." It has now become the fashion for birds to be rare, and thus large prices can be asked for specimens of the most common species.

The Red-breasted Merganser, Goosander, or Earl Duck has been found breeding in some parts of Great Britain, but I refrain for very good reasons from mentioning the names of such places. Scotland and Ireland, as might naturally be expected, are more favoured by this species than are English waters on the southern coast, and a full-plumaged bird may be considered rare, although northwards it is not thought uncommon. It is very nimble in its movements, and to get the chance of seeing it you must go to places which are, as a rule, most carefully avoided by all but genuine sea-dogs, on account of the sand-bars. Those who have gone through the race or cut of a dangerous bar need not be told what it is like, they know well that the sooner one is out of it the better. One sketch will be enough.

" Not a damned bunch o' feathers among the lot on us, an' we left port at sunrise. I don't like the notion o' beatin' roun' the bar. 'Tis a long sail, an' a dirty one 'twill be if we wentures it, an' no mistake, if I reckins right the tide's makin'. Shall us foorce through the cut? What says the crew o' this 'ere 
craft? I be only one among ye. Whichever 'tis to be must be settled quick one way or t'other, if we wants this cruise to end well. 'Tis middlin' smooth as yit at the mouth on it. But not for long it wun't be. Look at the rib o' that unfortunate craft stickin' up, an' there's another just showed; she's broke up to match splinters-see 'em wiggle? The bar feels the tide, look at it bilin' at the mouth. Now then, out with it, through or round? Through! All right, my lads, we all fares alike, sink or swim."

Peering like a cormorant, first on one side and then on the other, the man appeared to be listening intently. Then he said--

"The tide's racin' through the cut. Here she goes."

It would be quite useless to attempt to describe on paper what that passage through the cut was like. No one spoke a word. There sat our old seadog grasping the tiller, and, had it not been for the glitter in his eyes, he might very reasonably have been taken for a stuffed scarecrow.

"Never more," thought one member of that crew; "if this adventure turns out well, all's well, but it is one to end with," for it was a creepy experience. with the boiling waters below and the live sands above, and the hiss of it all.

"Hold fast!" roared the skipper, and then there was a grating rishe, rishe, rishe, and a bump. "Cleared!" he roared ; "stick tight." We were going at a rare rate.

Another lone rishe, rishe. The bow of the boat rose, pitched again, and once more rose. Then we 
shot out into open water. We had cleared the cut of the bar.

Immature birds belonging to this species, that of the Red-breasted Goosander, are more frequently to be met with than would be thought probable by some people. But it must be remembered that it is impossible to ascribe limits to the range of fowl, and that much confusion has been caused in former years by classing, in different localities, the young of different species, as well as the adults in different states of plumage, under one comprehensive heading of Sprat Loons, Dun Divers, or Sprat Divers. This is not surprising, as on the water the fowl swim low, and at a little distance off, from the deck of a vessel or from an open boat; all these species look much alike, and also of one colour, grey and white.

The small Merganser, known as the Hooded Merganser, belongs, properly speaking, to North America, but occasionally it is seen off the coast of Ireland. So-called English-killed specimens have, it is true, been looked on with suspicion. But it must be remembered that even those naturalists who pose as great authorities do not shoot all the rare birds which are to be found in their collections, and as this bird has at different times reached Scotland, what should prevent it from coming a little further south during hard white weather?

The last Hooded Merganser drake which I examined had been shot not far from the coast-lines of the borders. The owner did not even know what the bird was, and he had not the least suspicion that 
I was interested in bird matters. He simply said that a friend of his in the north had shot the curious bird, stuffed it, and sent it south for him. Upon my venturing to remark that the setting-up might have been better done, I was told that the man who had sent the bird was, to be sure, a home-spun stuffer ; but there it was.

The Smew is the smallest member of the family to which it belongs, and it is also the least numerous compared with its relatives. On the southern and eastern coasts Smews are found at times in considerable numbers, which chiefly consist of the females or young birds. The full-plumaged black-and-white drake Smews are rarely to be procured, as they keep well out at sea.

This beautiful bird is extremely active both when on the wing and when diving. It has various local names, such as White Niun, Pied Diver, Vare Wigeon, White Wigeon, and W'easel-headed Wigcon. The last-mentioned title has been bestowed upon it because the clean-cut, red-tinted heads of the females and the immature birds, together with their bright eyes and general perkiness, reminded some of the shore-dwellers of the weasel.

It is a well-known fact that, with the commoner species of fowl, full-plumaged specimens are not easy to get. As regards the bird under notice, it is at times almost impossible to get one in full plumage on the waters that surround our coast-lines. Northern specimens can of course be procured in adult breeding plumage without difficulty, but 
258 WILD-FOWL AND SEA-FOWL OF GREAT BRITAIN

British specimens of such birds are not easy to get.

THE BUFF-BREASTED GOOSANDER.

(Mergus merganser.)

MALE.-The bill vermilion; the nail black; iris bright red. The head and upper half of the neck black, with green and purple reflections. Lower part of neck white behind; its front part, and the whole lower surface and side of the body, a delicate reddish-buff or light salmon colour. The fore-part of the back and inner scapulars black; the hindpart ash grey, waved on the sides of the rump; the tail ash grey, with black shafts. The outer scapulars are white, hiding a band of black, margining the wing and crossing its base. Wing coverts white; outer secondaries black at the base, forming a bar across part of the wing; quills blackishbrown, tinged with grey on the inner webs; legs and feet vermilion. Length, from bill to tail, twenty-six inches.

Female.-Has a longer and more slender crest than the male. Head and upper neck light reddishbrown; upper parts deep ash-grey. The throat whitish; lower neck pale grey, the feathers edged with white; breast and belly white; the sides grey. Some of the secondary quills and their coverts white. The bill and feet duller than in the male. Length, from bill to tail, twenty-four inches.

Young birds, similar in colouring to the female. 
THE RED-BREASTED GOOSANDER.

\section{(Mergus serrator.)}

MALE.-The bill rich vermilion; the nail yellowish-grey; iris blood red; the head and upper neck greenish-black. Two tufts of the lengthened crest project from the rest. Back black before, grey with dusky lines behind. The middle fore-neck light red, streaked with dusky colour; breast and belly pure white. A tuft of large feathers before the shoulder-joint white, with broad black margins. A white patch on the wing, and two black bands. Legs and feet deep vermilion. Length, from bill to tail, twenty-five inches.

Female. - The head, hind-part, and sicles of neck half-way down light reddish-brown; throat greyish-white. Lower part of neck, all round, greyishbrown, the front feathers tipped with white; rest of lower parts pure white; upper parts brownishgrey, the feathers edged with grey. Small wing coverts grey, without the white patch seen in the male; quills brownish-black. One dark band on the wing. Bill and feet paler than in the male. Length, from bill to tail, twenty-three inches.

\section{THE HOODED GOOSANDER.}

\section{(.hergus cucullatus.)}

MALE.-The bill black; nail whitish; iris yellow; upper part of head black. A large patch of white on each side behind the eye, showing 
conspicuously when the crest is raised. The rest of the head, half-way down the neck, two bands before the wings, and hind-part of neck greenishblack. Upper parts of body brownish-black; tail greyish-black; smaller wing coverts partly grey; primary quills and coverts brownish-black; outer secondary quilis and coverts greenish-black, white towards the end; the inner white, with black margins. Lower parts white; the sides finely waved with yellowish-brown and brownish-black. Legs and feet dull yellowish-red. Length, from bill to end of tail, nineteen inches.

Fexale.-The crest smaller; upper part of head reddish-brown; cheelss and upper neck brownishgrey; back blackish-brown; throat greyish-white; lower part of neck grey. Lower parts greyishwhite; the sides dusky brown. The wings without white on the inner secondaries. Length, from bill to tail, seventeen inches.

\section{PIED SMEW.}

\section{(Mergus albellus.)}

MaLE.-The bill greyish-blue; iris bright red; the lengthened feathers on the head and nape white. A broad patch on the fore-part of the cheek and a band along the side of the occiput greenish-black. The back is black, shading into grey behind; neck, scapulars, smaller wing coverts, and lower parts white. Some of the scapulars are edged with black; there is a black line on each side 
before the wing. Primary quills and coverts brownish-black; secondary quills and coverts black, tipped with white. Legs and feet light greyish-blue, the webs dusky. Length, from bill to end of tail, seventeen inches.

Female. - The crest shorter; the bill pale blue; iris red. Upper part of head and hind-neck brownish-red half-way down; fore-part of cheek reddishblack; its hind-part brown. Throat white for half its length; lower neck, all round, ash grey; lower parts white; the sides ash grey. Middle of back greyish-black; hind-part, scapulars, and tail grey. The wings as the male's, but without the darkcoloured smaller coverts; legs and feet greenishblue. Length, from bill to tail, sixteen inches. 


\section{CHAPTER XXI}

THE WIGEON AND POCHARDS

The Wigeon is a beautiful bird, and at the present time it visits the southern parts of England in great numbers. Colonel Montagu states that at the time he wrote, the Wigeon was taken in the decoys in greater abundance than any other species of duck. In the decoys of Somersetshire and Devonshire more Wigeon were caught than Duck, Teal, and all other fowl put together.

One of the most expert fowlers, having a fowlingpunt and gun of the day, and being moreover a most observant naturalist, states in one of his works on the subject, that what deer are to the deer-staller the Wigeon are to the fowler. These birds are grass-feeders, feeding on both meadow and sea-grass by day when the chance offers, and at night when circumstances compel them to do so, being able like other creatures to adapt themselves to their surroundings. One sketch of the IVigeon's favourite feeding-flats let me give.

The tide has gone out, leaving a wide mid-channel of deep water, which at its narrowest part is more than a mile in width. On my side lies a mile and a half 262 
of wet marsh and slub ooze, the latter being covered with sea-grass (Zostera marina). On the opposite shore the slub and drowned marshes are more cxtensive. Looked at from the rising grounds above, there seems a bewildering network of mud-flats, sand-bars, and water-channels. Even when the tide is out there is plenty of water left, and the great pools here and there are as large as mill-ponds. Not only does the whole district smell unwholesomely, suggesting fevers and ague, but it also contains more death-traps in the way of ooze-quakes and shifting sands than any place which is known to me. None but the fowlers and fishermen can work in and out of those dangerous channels and gripes, alternated with sand-bars and sandy ooze, and where grass covers the ooze nearest inshore, beyond it is mud pure and simple.

Hundreds of fowl may be on one side of a sandbar, while on the other your flat punt creeps along, but never a bird will fall to your share, unless indeed they should rise and come over, a very unlikely chance, as they are feecling busily.

There is a cut through that sand-bar, a winding cut which divides it as a ditch divides a double hedge, and it is to all appearance as calm at the opening as is the water in a pond after rain. But this appearance of calm is fearfully deceptive. 'The water comes from the main channel. Once get fairly into that cut through the bar, and you will be shot out at the other end, utterly shipwrecked, food for the hungry crabs. 
In such sanctuaries rest the divers. This comprehensive term includes Mergansers, Grebes, and the divers proper. As sprats are found here in enormous quantities, while smelts, shrimps, and flat-fish also abound, the class of birds feeding solely on fish, in some shape or other, congregate here, where their food can be procured in great quantities and in the easiest manner. When fowl have to work hard for their food they become thin and tough. No one, however, unless he were very unsophisticated, would venture to try culinary experiments on a diver.

Hosts of waders frequent these flats, slubs, and sands; clouds, trips, and mobs of birds, all very wide-awake, and, as far as the sense of self-preservation goes, very highly educated. They know, even if they are busily feeding, exactly how far they mean to let your punt creep up towards them, and when they rise they will not come in your direction. I have once or twice filled my shooting-pockets, but have only been able to get the birds either singly or by couples, the greatest number that ever fell to the shot being four, and this was when they came spinning along the lap of the tide.

The birds look at a distance quite a dense mass. Any one unused to them would expect it to be as easy to drop at least a dozen as it would be to shoot into a barn with the doors wide open. I have known people holding such an opinion to be taken out on purpose that they might have a chance of proving its truth, and yet never all through the day have they been able to drop a single bird. Even a 
good shot will sometimes miss clean; and indeed it would be a bit rough on fowl generally if his shots invariably told. The duffer, strange to say, never misses. Such at least is the tale he tells his friends, and they spread the story after he has shown them the fowl he has, in reality, bought.

Some folks I know have been under the impression that in order to have good sport among the fowl it is only necessary to read up on the subject, take a double punt and engage one of the numerous water-side dwellers to pilot them; and those who have availed themselves of the means just referred to have been rowed up and down dirty, stinking channels, which, but they did not know it, were only used for coal-barges. They had paid well, but to my knowledge they never got so much as a Dunlin (Ox-bird). However, the Munchausen yarns that were told them about fowl, to keep them from shivering, were really worth the money. Of course the man who rowed them up and down was warm enough, and the lookers-on from the sea-wall kept themselves warm by laughing. When the amateur fowlers got on shore for comfort, how kindly did that party on the wall condole with them and offer advice, being in return generously "liquored up."

"If they would only stop to flight-time (the dusk), they would drive some over to them."

The victims believed these promises and did stay, and the lookers-on laughed more than ever. The fowl did not show and the cold was bitter. Once more they got on shore, called for something 
extremely hot, and left for the station escorted by friends and admirers still condoling with them and giving advice, this time free of cost.

A fowler or a fowler's puntsman never has clealings with such people; he simply scorns them and their money too. But prowlers and combers can be found on most fore-shores, and to wait on such would be an experience such as I have sketched. Men have left places where thousands of Wigeon alone, to say nothing of other fowl, fed at each ebb-tide, and told their friends that not one bird of any kind had they scen. They had not seen them for the excellent reason that it had not been intended that they should. One of my oldest friends when he was living, used to say that "a fool aboord a boat was a wusser o' a cargo, and some on 'em ashore was wuss still."

In the day-time the Wigeon were out at sea, like the ducks coming in to feed on the sea-grass at dusk, night, or in the grey of the morning, according as the tide suited. If the weather were fair, flighting and punt-creeping answered, as when food was being easily got at very little noise moved the birds. Noise was never intentionally made, but accidents, such as a punt getting aground, will sometimes take place in spite of all precautions. They well know what that grinding hiss means. Or perhaps a paddle will hit the sides of the punt, such things do and will occur. You may feel happy in the fancy that for once all will go quite right. The punt as you paddle is just below the ooze-level, and the birds are pretty close; you can hear them mew and purr. The mud- 
pattens are ready, no time is to be lost on cripples; "the dead are dead, but cripples are lively," all fowlers know that saying. Your heary shoulder duck-gun is over the bows of the punt, you are lying at the bottom of it llat on your breast. "It cannot be less than four," you fancy, "let the worst come."

Your legs are cramped in that humble position. You move one of them a very little, and your heel just hooks off one of those mud-pattens. Down it rattles, and you have spoilt not only your own chance but that of others. Plenty of food and fair weather cause the fowl to "feed picksome," as it is called; in other words, not being hungry they are on the alert. You may see flashes and hear guns from other fowlers, hid up mich nearer to you than you would have suspected; but they are all flight-shots, some of them being to very good purpose, for flop! flop! flop! can be heard, as they fall down on the ooze. The best thing for you to do is to paddle your way out and go home, miserably conscious that you have managed, although unintentionally, to wake up the flats for this tide.

Fair shots on the ooze confuse fowl, but any mishap such as has just been described alarms them. The reader must distinctly understand that I am describing the ways and means of local fowlers, who have their punts made to suit their own notions; most of them, in fact, being home-made, and the long, heavy shoulder-guns are temporarily rigged up as punt-yuns. Plenty of fowl are killed at the present time in this way by some of the 
marsh-men; their accurate knowledge of the fowls' habits and the localities they frequent making up for the want of large guns. If the magnificent productions of the boat-builder and the gun-maker help to produce generous results in the way of fowl (I need not enter into this matter at length, as all fowlers will at once know my meaning) all will go well, and the crew of that punt will make friends; and this will be a good thing, as high-handed proceedings do not answer with the marsh-men. As regards steam-launches for fowling, want of space and lack of suitable language forbid such a subject being dwelt upon.

Out on the open water weather is rough, and there is a general state of high-water and of rivers full to the brim, the salt water keeping back the fresh. "Drownded mashes," for miles, are the consequence. All the sprat, oyster, and shrimping crafts are at their moorings, and some of the fowling-punts are drawn up in their owners' gardens, while the salt water lips the front-door sills. This state of affairs has lasted three days, and the whole of that time the flats have been under water even with the tide at ebb, as then the pent-up fresh water was rushing down - at least it had been fresh; now it was more than brackish.

Then all at once there came a lull, and the lonely hamlet was busy as a hive of bees because the moon was at first quarter. There would be a full tide, not a high one, made after dark, and with that tide the Wigeon would come. Some had come in 
the day, but the lead had not been fired at for good reasons. Guns were cleaned and punts made ready. Those who fowled on shore, or rather in the mud, borrowed their wives' hand-bowls to bail out their tubs, which were brimful of the mud in which they were sunk, and then they put straw in them to make them snug. Those who shot on shore went to their places and made them comfortable also with straw, things generally being in a decidedly moist condition.

When the flats became fairly dry, and the fowl, nearly all being Wigeon, rushed in from open water, the place was absolutely alive with fowl. "Whe-ohwhe-oh, wc-we-oh," and "quack-queck, quack-quarkquack," and then "Honk-honk, honk." The waders twittered and whistled, the Curlews were first on the list for noise, and the "cussed yelpers" were second best.

All were busy feeding, but as far as the waders were concerned all were unheeded, Wigcon being destined to be the order of the night. Still they come, and now the tide is flowing. A line of punts comes down the cut, the punters having settled before starting, if possible all to fire together, and to share the fowl. The men take their places and drift up with the flowing tide. The flats may look level, but they are not really so. As the water floats them off their feet, getting finally too deep for them to feed, all the fowl make for a shping length of ooze covered with grass, not yet reached by the water, and here they grorge themsclves voraciously. 
The tide creeps up; so also do the punts. So thick now are the WVigeon on their last bit of feed that there is barely room for them to move about. The punts are near enough. Four reports ring out before the birds can rise, and three more as they spring, then the tub-shooters get at them, followed by those on shore. Mud-pattens are put on and much gathering takes place, indeed, according to one fowler's statement, there would, when all the fowl were reckoned up from that fortunate manœuvre, be enough to fill a small cart. But such a chance as this does not often present itself. When it does, it is taken advantage of and is duly recorded in the chronicles of the hamlet.

The Red-headed Pochard is locally known as Duncur or Dunker, Red-headed Poker or Wigeon Poker, and Great-headed Poker. At present he risits our shores in great numbers, but owing to the consequences of draining the meres and lakes he is not seen now in this country in such vast hordes as in past times, which are well within my recollection.

The Dun-bird is a good diver, and brings up the food he obtains, to eat it on the surface. Sea-grass (Zostera) is one article in his bill of fare. Although at times the birds cover some quiet pieces of fresh water, they are reckoned as sea-ducks. This term is used comprehensively on the coast either for on-the-water or on-the-wing birds, but there is as much difference between the build of a surfacefeeding duck and of a diving duck as there is 
between a passenger steamer and a steam-tug. The surface-feeding ducks can dive, and do under certain circumstances; but they do not dive for a living, the others do; and the diving ducks without any exception are stoutly-built birds.

Pochards are as hard as nail-bags, and require a lot of killing. If they are dead, well and good, but it is only lost time to pursue wounded birds, even by boat, for you will not get them. They are thorough divers, diving not only deep but far. Their bills will occasionally be just poked up for air, and then away they go again.

Bays and estuaries of great extent suit Pochards, if water-not fresh, but what the marsh-men call the "dead drinking-water"-that forms the fleets and lagoons is close to them, with reed and sedge cover. They will leave the tide to rest there, and in Essex ponds were specially formed for their capture.

Essex has been, and is now, I think, equal to Lincolnshire or Norfolk as a resort for fowl. The great estuary of the Blackwater river, with its miles of ooze, covered with food at low water, attracts them, as it once did on the opposite shore. The Essex decoys were, from the nature of the feeding-slubs. situated near the tide. Three only are known to me now as being in use, at least they were in use in $1 \$ 86$ or $18 S 8$, but twenty-six are no longer used. This important fact speaks for itself.

I shall not speak of the tons upon tons of fowl captured in past times. Full particulats, carefully. 
compiled from decoy records, have been published by men who were well acquainted with the matter. Comparatively recently, that is to say, only forty years ago, I saw such quantities of fowl taken there and at the mouth of the Thames and Medway, that an attempt to give any idea of the numbers would seem ridiculous. They were there for all to see and to get if they could; and as far as reducing their numbers was concerned, shooting made no more difference than dropping half-a-dozen out of one of the great flocks of sparrows that congregate after the corn has been carried; the fowl are shot both on the ticle and on the slub, but the numbers dropped are a mere nothing.

Given the most favourable conditions and the greatest exercise of both care and skill, thirty dead fowl is in my opinion a good shot from a punt gun. This number has been placed in a punt from one shot, but what is that out of thousands? It is dangerous work anyway, both for professional fowlers-that is, those who live by it in the season -and for the gentlemen fowlers who fowl for sport. Wild-fowling is very expensive when all is reckoned up, but it is the cream of sport.

Seeing fowl and getting at them are two different things. Men will give at times vivid accounts of their fowling experiences in and on the places I have mentioned. Not so much accounts of fowl killed, but of their own escape from death-traps. Some would tell that no fowl were to be had there. There may not have been for them, yet all kinds 
of fowl were there if you could only get at them with the gun.

The decoys captured the fowl, Ducks, Teal, Pintails, Wigeon, and Pochards, but the Pochards were captured in a different way to the other fowl: the piece of water arranged for their benefit was called a pond. Round the pond were high nets fixed to poles that lay flat on the ground. These nets were placed near the edge of the Pochard-pond, and at the foot of each net a deep trench was dug.

When there was a good lead on the pond, from seven to eight hundred or a thousand, the fowl were raised off the pond. As the nets were arranged with balance weights, directly a string was pulled they stood upright. According to the direction of the wind the nets were used. It takes a Pochard some time to rise clear of the water and well above it ; they rise head to wind.

All is right for the catch. They are raised up and away they go. Just before they reach the edge of the pond, up fly one or two of the long high nets, and they hit against the meshes like a swarm of flies, only they do not stop there. They simply flutter or drop down the net into the trench at the foot anyhow, one on the top of the other. There they lic helpless; they are not able to make use of their wings when they are in the trench.

One great catch of Pochards is a notorious fact well known all along the fore-shores. It is the one folkard has mentioned in his IVildforiler in 1875 .

IVhen writing about the Pochard-ponds he tells 
how on one or two occasions within present memory the capture of Pochards, or Dun-birds as they are locally called, has been so great at one drop or pull of the net, that a wagon and four horses have been required to remove them, and he states further that these birds have been known to resort in flights so numerous as apparently to cover every available space of water in the pond, and that five hundred to six hundred Pochards at one rise of the net was in those days considered quite a moderate capture.

I have lived to see some remarkable changes, and to see the fowl decrease in numbers. This is to be laid not so much to the changes as to the increased facilities for getting to the haunts of fowl, which was at one time impossible. Now any person who has money enough to pay the gun tax and the hire of a man and skiff can go Gull-crippling, or at least make a try at it. It is pop, pop, pop, and nothing comes of it unless a Gull, presumably bent on suicide, flies almost up to the gun-barrel. How many powder-wasters and Gull-frighteners I have seen! Sad fatalities occur among these still wild haunts, do what man will to bring them under his control. These, however, will not be mentioned, my aim being to deal more with the bright than the sad side of the matter, although mishaps take place in covert shooting as well as when by the ticle.

There is a strangely-built diving-duck which is known to shooters as the IVhite-faced Duck, Frostbacked Wigeon, Spoonbill Duck, and Scaup. It 
arrives on our coasts at the end of October or early part of November, according to circumstances.

Scaups are better to look at than to eat. Before the commoner kinds of shell-fish reached the markets in the quantities they now do, these birds were more numerous on some parts of our coasts than they are at present. Creeks and harbours have been altered, and dangerous masses of rock have been blown to pieces, to the untold benefit of all sea-faring folk, but not to that of the Scaup. Those who have from a boat looked through the clear water, down on these rocky gardens when the tide was full during calm weather, will fully understand what is meant by Scaups' diving rocks. The wrack and weeds are full of marine creatures, some nimbly swimming, others resting on the weeds. Spat, as the young of shell-fish are comprehensively called, require while they are tender a certain amount of shelter. This was supplied by the weed-covered rocks, which were at one time far too numerous. I have seen a creek with tortuous bends, some of them very sharp ones, leading direct from open water to a good harbour well inland, covered at low water with shell-fish, mussel-scalps, winkle-hards, cockle-patches, and crabs.

No matter how it tossed and thundered in open water the fish were all right in their creek. Old piles, weed-draped and all awash at high water, contributed their share towards comfrot. 'The fish scemed to know all about it quite as well as the bircls. I have seen them landed with rod and line 
just as fast as hooks could be baited. When the water was clear, clouds of small creatures could be seen going in and coming out of the cavernous openings of those old and rotting piles. Even at dead low water I never crept inside them, venturesome even as I was, for some grim traditions hung about those old pile wrecks.

I should certainly never buy a Scaup Pochard to eat. One of my earlier friends once sold a couple to a person who had pestered him, as he said, to let him have them. The man who bought them insisted that they must be good to eat because they looked so handsome. They were cooked, and the attempt was made to eat them, but it somehow failed. The next time that Scaup-eater met the shooter he told him that he had had enough of Frost-backs to last him a lifetime.

They used to remind me when about their haunts of the handsome Dutch luggers which sailed over their diving-grounds, not over the rocks, though certainly both birds and boats were built for the water. When spring draws near they leave us for their breeding stations in other lands.

Shooting Scaup from a boat or punt is not so easy to do as to read about, because although to those on shore the water in a dead calm appears quite pulseless, the sea is in reality never still, and you, looking down on the weed-covered rocks below where the wrack streams out and then drops down again, are quite aware that the boat you are in does not remain where you sculled her to. There is not 
a breath of air stirring, but she has somehow got round the other side of the rock-heaps, so that if you are flounder-netting you have to bring her round again. A school, as it is called, of these goggle-eyed dainties is well worth the trouble of baiting for and catching. Spearing in calm, clear water is very good sport, but for table purposes the fish are better netted. I have had a catch of flounders all alive and leaping, and within an hour after I have been eating some of them fried in egg and bread-crumb. That is the way to enjoy fish.

Now-a-cays Scaups are frequently netted. This was not done in my time, when those birds that were killed were shot, with the exception of a few captured with more valuable fowl in the decoys. Sometimes, though not always, their capture is comparatively easy, because they feed with the tide, that is, they come in with it, diving as they advance shorewards. A good bit of shell-feed where they come in is picked out at low water and a net is stretched out on driven-in stakes. When the tide flows, this is all completely covered over, and the birds in diving get tangled in the meshes and are drowned. There secms just now to be a market for every crcature, living or clead. This is sometimes to be regretted. Some of the Scaups go to the bird-preservers, and a great number-because they are, as one of my fishing friends once said, "not donkey mutton, and not good dog fish"are caten in certain establishments on fast-days. Before quitting this subject it may brichy be said 
that although as a roast certain web-footed fowl are not to be clesired, yet when turned into soup they are delicious.

I have in my time tasted jumble soup made from fur, feather, and fin. It was composed of a rabbit, one partridge, the latter having hung just long enough - a very little more suspension would have been too much-four thrushes, three blackbirds, and last, but by no means least, half-a-dozen good perch skinned and cut up with the others. The seasoning and a few trifles were, if memory serves aright, borrowed, so too was the iron pot the soup was made in, and also the firing. The dinner service consisted of two wooden jam spoons and a rusty iron one cleaned up for the occasion, with a couple of pint pots and a basin chipped round the edge.

How carefully was that soup skimmed and kept just on the simmer by one who had fed many a wood fire before, with a stick here and a stick there, until, long before the concoction was ready, one of the party observed that it smelt "right down moorish."

Shall I ever forget that meal, and how, when it was over, we, as the old Irish song has it-

"Swore to a man, that not Judy Phelan Ever made such a potful of soup"?

What a pleasure it is when one is no longer young to think over such experiences! I have wandered a little from the subject of the Scaup, but at one time of my life fishing and fowling were inseparable. 
"There's two if not three o' them Frost-backs diving round the old piles. Just cum, I reckins. Cumin', ain't ye? The water's smooth, and a bit o' fog creeps, but it ain't nothing."

However, I declined, as I was bruised in various places, through having slipped off those old piles the day before; in fact, I was what one of my friends called "a crippled fowl." This little matter is explained, but the shooter is not contented with such an explanation.

"Ye ain't broke nothing, hev ye?"

"No."

"Ken ye walk ?"

"Yes."

" "Vell, what's to perwent ye cumin'?"

"I can't shoot, I'm too shaky."

"Nobody wants ye to shoot. Ye ken steer, so cum on. I'll put ye in the starn, and wrap ye up like a babby."

That comparison with an infant just about did it, as he had no doubt expected, and in no measured terms I told him that I did not feel the least bit dead, finally recommending him to go to a certain place where sulphur can be had at a cheap rate in very large quantities. But he only grinned and said"I knows you'll come now."

Down I went with him, for like the rest of his class he was a good oarsman. Once he slacked a bit to tell me that his gun was loaded with swanshot, because, he said, "Them Frost-backs ken take sumthing. Bring her in a bit, will ye, so as she'll 
drift round them piles! I'm going to in oars. Right, my son; right ye are, she's going fine. Keep her a leetle wide o' thet 'ere fust pile-snag. She'll drift round now like a swan."

"Ease her a little," he whispered, "fur if they're diving it's in the slack t'other side. Ease her."

Round she went like a drifting leaf, up went his gun to his shoulder, ready for action. I just saw a couple of forms going under water; then the shot rang out. When the smoke drifted to one side, I saw a young Scaup drake turned turtle, his great paddles working and his white-fronted head moving from side to side.

"Sharp work, waun't it? He won't kick much longer. I've got ye;" but just as he stretched out his hand to gather him in, that young drake righted himself and dived like a flash. The bird was not seen again. No doubt it afterivards died; but never, unless the bird is desperately crippled, will a shooter follow a wounded Scaup-he knows how useless it would be.

The Red-crested Pochard (Fuligula mufina) and Ferruginous Duck (Fuligula nyroca), or White-faced Duck, as it is called on some parts of the coast, are not likely birds to be met with in the course of ordinary shooting. Although made on the strongest lines, regularly built for the water, diving ducks get drowned when the weather is very bad, for then the life is literally battered and washed out of them. 


\section{THE IVIGEON.}

\section{(Marca penelope.)}

MALE.-Bill greyish-blue; nail black; iris hazel. Upper part of head reddish-white ; cheeks and upper neck brownish-red, dotted with black; a lengthened band of the latter on the throat. Fore-part and sides of lower neck are light vinaceous; upper part and the sides below the wings finely barred with dark grey and white. Wings grey, with a large patch of white; the speculum green, with a black band before and behind it; the secondaries white, grey, and black. The upper tail coverts partly black; tail grey; breast and belly white; the feathers under the tail black. Legs and feet light greyish-blue, the membrane being darker. Length, from bill to tail, twenty-one inches.

Finale-A smaller bird. Bill, iris, and fect are similar to those of the male. Head and upper neck yellowish-red, with black spots. The feathers of the upper parts generally are dusky brown, edged with brownish-red or whitish. The wings are dusky grey ; the speculum greyish, and without gloss. On the lower fore-part and sides of the neck the feathers are faintly barred brown and giey; breast and belly white; feathers under tail barred with brown.

THE, POCHARD.

(Fuligula firina.)

M.I.F. - Bill black at the base and at the end, the rest being of a light greyish-blue; iris orangre. Head 
and half the neck, all the way round, rich orange brown, lower part of the neck brownish-black. The upper parts are very fincly waved with dark grey lines on a greyish-white ground; the hind-part of the back and upper tail coverts brownish-black; the tail greyish-brown. The primary quills are brownishgrey, tipped with dusky brown; the secondaries are ash grey, edged with white; the coverts are grey, edged with whitish ; the breast is pale grey, the hindpart of it and the sides being waved faintly like the back; the belly is greyish-brown, indistinctly waved, and the feathers under the tail are blackish-brown. Legs and feet are lead colour, and the webs black. Length, from bill to tail, eighteen inches.

Female.-Smaller. Bill, eyes, and feet coloured like those of the male, but the blue band on bill narrower. The head and the hind-part of neck are brownish-red; the fore-part of cheeks, a space beneath and behind the eye, and the throat are paler. Upper parts greyish-brown; fore-part of back waved with whitish; tail greyish-brown. Lower part of the neck and a part of the breast are also greyishbrown, but the feathers of these are edged with brownish-white. The middle of the breast is greyishwhite; the flanks dusky; and the belly grey brown.

\section{THE SCAUP DUCK.}

\section{(Fuligula marila.)}

MaLe.-The bill light lead colour, the nail nearly black; iris bright yellow. Head and upper half of 
neck black, glossed with green and purple; the rest of the neck and part of the back and breast black; middle of back, scapulars, and wing coverts white, waved with dusky lines ; hind-part of back brownishblack, tail greyish-brown. Outer secondaries partly white, primaries partly greyish-brown; breast and sides white. Belly and lower tail coverts dusky; legs and feet pale greyish-blue, the membranes dusky. Length, twenty inches.

Frmale. - Head, neck, fore-part of back and breast brown; a broad band of white on the forehead, upper parts blackish-brown, in part waved with whitish; middle of breast white, sides and hindparts dusky brown. Length, eighteen inches.

Tine Young Birds. - Almost like the female, the white in the latter and in the young giving rise to the term "white-faced." 


\section{CHAPTER XXII}

ThE GUILLEMOT, LitTlE AUK, RAZOR-BILL, AND PUFFIN

Foolisin Guillemot, Sea-Mew, Tinkershere, Bad Willy, Willock, Scuttock, and Scout, are some of the local names for the Common Guillemot. This small diver, like its larger allies, for it is formed on the same lines, follows the shoals of surface fishes all round our shores. Surface-swimming fishes are mackerel, herrings, pilchards, sprats, and whitebait. As small members of the different species are about, as well as larger ones, there are plenty of them and to spare. Other marine creatures help to fill the stomachs of the birds beside fish, strictly speaking. About their breeding haunts or habits we have nothing to say, at least we do not feel inclined to say anything, for that subject is worn out. They are most amusing birds to watch, and, as one of their titles indicates, are of a confiding nature. Though called foolish, this is not the case; when diving the Guillemots, like the Loons or Sprat Divers, use their wings as well as their feet. It is a case of flying under the water, and that is the reason the fish are not able to get away. 
GUILLEMOT, LITTLE ACK, RAZOR-BILL, PLFFIN 28 ;

The Little Auk is at home on the waves; he is not much larger than a Quail, a small, plump, active Harlequin, in a suit of black and white. The only adjective that seems appropriate to him as he goes scooting over the water, or when he sits up at times, is that of funny; a frog in a brown study, looking hard at nothing, is not to be compared with the Little Auk for quaintness. Yet wave-dweller that he is, the elements at times are too much for him, and he and his get blown off the surface of the waters, like leaves in fall-time, when the wind rushes through the woodlands. Storms from the north-east and from north-north-east, when lifeboats are not able at all times to reach a vessel before she founders with all hands, are bad for sea-fowl. When Petrels flicker round gas-lamps, and drop on the pavement, or are caught by hand as they flick and flutter, then the Little Auk, Sea Dove, or Little Guillemot is found sitting on a doorstep, lost in wonder and amazement at its strange surroundings.

One of the forms of supplications taught me in childhood by women who had lost husbands and sons, "gone down," has often since then rushed involuntarily to my lips-"God help all at sea!" Common humanity suffers at such times, and so clo other creatures, and they will continue to. This little humpty-dumpty of a diver has been found on furze commons, blown there by gales much against the poor little creature's will. If it was possible for him to live there, no doubt after a time, according to evolutionary theories, he might develop into a Quaii. 
I have little to say of the Common Razor-bill. Where a lot of fowl are hard at work, fishing, they get so to speak mixed up a bit; and no wonder, when on the toss of the tide they are up and under in all directions, heads bobbing up and tails going down. A regular boil-up it is altogether; the nets, too, are heaving near the surface, ready to burst, and some of the birds are meshed in them, a rare mixture of scales and feathers. And that is how the best specimens are got for the bird-preservers, if the crew do not require them for eating. I knew very well why the men set such store by their bags of dried sage and their wicker hampers of onions, when they were on a fishing cruise. As the shape of some of the birds' bills under notice alter in their progress from the young state to that of maturity, also in summer and in winter, nice distinctions could not be expected at that time of day from the hungry crew of a fishing-smack; and a choice bit of fish, or a mess of fish cooked as fishermen only know how to cook it, is all very well backed up by something solid--fish alone will not keep the wind out of you; a good basin of Willocks and Razor-bills, stewed with sage and onions, and a good hunch of home-made bread a week old, will.

The Puffin sheds some of the horny parts of the bill in the autumn, so that the bill in winter is smaller. The young bird of the year has a very different bill to that of the adult. It is larger, but very like the general appearance of the Little Auk's bill. The sides of the young bird's head are grey, 
in fact it looks as if it had poked its head into a soot-bag. The upper parts of body dark blackishgrey, and lower parts white. The legs and feet are a dark flesh colour (livid) tinged with dusky, according to age; these parts brighten up. Bottle-nose, Sea Parrot, Gulder-head Pope, Mullet, Coulterneb, and Tammie Norrie o' the Bass, are some of the titles that the Puffin lives under. He is an excavator, a first-rate flighter and diver, and last but not least, a rare good fighter. It is only when he gets in a ploughed field thirty or forty miles away from the ticle, as he has been found recently, that Tammie gets put to it a bit; and even then he bites when he is picked up. Guillemots, Razor-bills, and Puffins have all been picked up this year-IS94blown far from home.

\section{THE COMMION GUILLEMOT.}

\section{(Uria troile.)}

MALE-The bill black; iris brown; head and upper part of neck black tinged with brown, which is lost on the middle of the neck behind. The lower hind-neck and upper parts are greyish-black: tips of secondary quills white; from the mildle of the fore-neck to the tail white. The legs and feet are dusky, with a tinge of red. I,ength, from bill to end of tail, seventeen inches.

The: female is similar to the male.

llinliy plumage. When the autumn moult is finished, the greiter patrt of the dark brown of the 
head and upper neck is replaced with white; throat, lower part of cheeks, sides of neck, and all the lower parts white. There is no external difference to distinguish the sexes.

\section{THE LITTLE AUK.}

\section{(Mergulus alle.)}

MALE.-The bill black; iris dark brown. The upper part of head, part of the cheeks, hind-neck, and all the upper parts are black, with a green gloss on the back. There is a white spot on the upper eyelid. The scapulars are streaked, and the secondary quills tipped with white; throat, breast, and belly white; legs and feet dusky. Length, from bill to end of tail, nine inches.

The female is similar to the male, but smaller.

\section{THE COMMON RAZOR-BILL.}

\section{(Alca torda.)}

MALE.-The bill bluish-black, a white band crossing each mandible, the upper one shaped like a short bill-hook; a fine, white, thread-like line from the upper mandible to the eye. The upper part of head, hind-part and sides of neck, and the upper part of body and wings are black, with a tinge of green; the secondary quills are margined with white. The throat, sides of head and upper neck, fore-part of neck, and rest of the lower parts are 
GUILLEHOT, LITTLE AUK, RAZOR-BILL, PLFFIN 289

white; legs and feet black. Length, from bill to end of tail, seventeen inches.

The female is similar in plumage to the male, and not to be distinguished at sight.

In winter, the upper part of head and nape of the neck are greyish-black; throat and sides of head white, with a dusky band behind the eye. Other parts very like the summer plumage.

\section{THE PUFFIN.}

\section{(Fraterula arctica.)}

MALE. - The bill has three curved furrows on each mandible. The basal rim and first ridge of the upper mandible are yellow; the space between greyish-blue; the basal margin of the lower mandible bright red; the first ridge, and the space between, as in the upper; the rest carmine. The wrinkled membranes at the base of the bill are yellow; the margin of the eyclids vermilion. Upper parts are black on the back, glossed with blue of a greenish cast. From the back of the hind-neck a band of blackishgrey crosses the neck. The sicles of head, from over the eye to the throat, are white; the cheeks tinged with grey, also the throat. The lower parts are white; legs and feet vermilion. Length, from bill to tail, twelve inches.

The female is not to be distinguished from the male by sight. 


\section{CHAPTER XXIII}

\section{DIVERS AND GREBES}

The Great Northern Diver, the prince of divers, is well known on the coast as the Ring-necked Loon, Cobble, Emmer, Sea-Herdsman, Great Speckled Diver, Gunner, and Ember Goose; it is one of the ocean wanderers. It is not the scarcity of this grand fowl that prevents his being seen very often in taxidermical establishments, but the bird's diving powers and instinct of self-preservation are so great, combined with his immense vitality, that the capture of a whale or a shark is an easy matter in comparison, with the circumvention, by any known means, of the death of this great diver in a full-plumaged condition. The young, as described further on, are frequently seen, and can be got at; I have had some sent to me just lately, fresh from the tide, but they were in their first plumage. Not the most profound scheming of as good a lot of shots as ever tossed on the tide has yet been able to do what some fowling friends of mine have long been trying, namcly, to place in my hands a fullplumaged Northern Diver, with the damp salt spray 


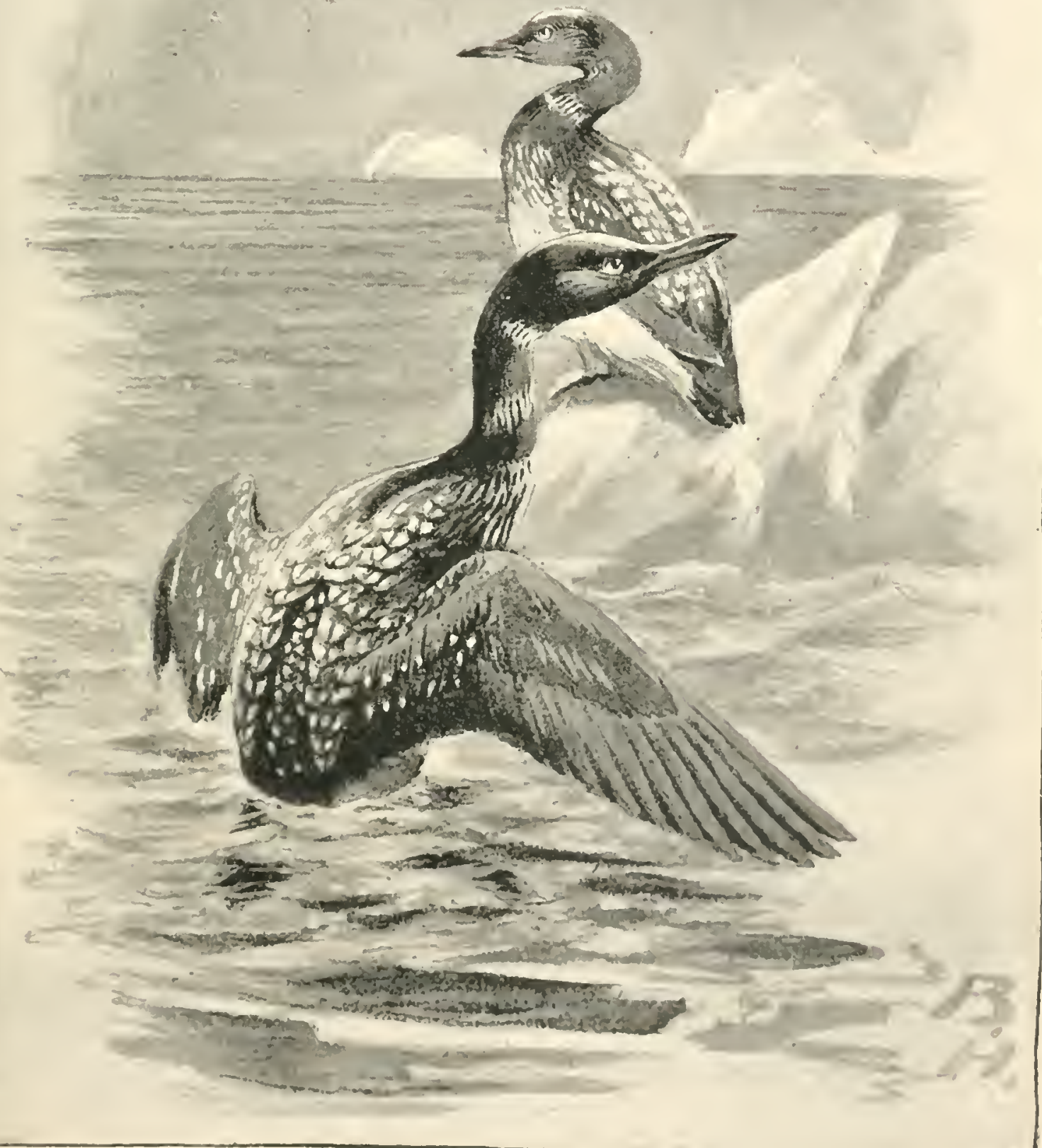

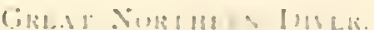




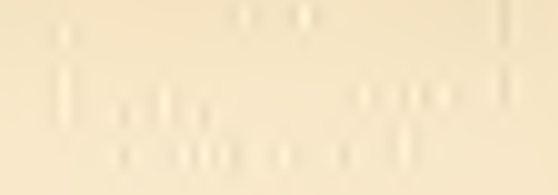


on his feathers. Skins are easily got, but these are of birds that have not been killed on our waters. I am hoping for one presently that has been killed on the tide. As regards the question of the nesting of this diver on any part of our remote British Isles, opinions differ, scientific ones especially. The bird has been mixed up with the Black-throated Diver, the next on our list, and very naturally so. All birds differ in size; and as to plumage, especially when it takes two or three years to perfect it, ordinary observers, and, indeed, very keen fowlers, full of good practical knowledge, if without theories, get a little bit puzzled at times. For my own part, I firmly believe this bird has nested on our remote northern isles. I have given in cletail, to the best of my ability, the old and young states of plumage, because the question is a very vexed one. Once I was present when a lot of fresh-killed fowl were ticked off as to titles, almost before they were seen. "Yes," the shooter said, who had procured them, "all very well; you says they are so, but are they? I think not."

That very handsome bird, the Black-throated Diver, breeds on the islets of the hill lochs of Scotland, although it is the rarest of the three divers that visit our waters. It has been procured in mature, but more frequently in immature, plumage on the tide and tidal waters. All of the said birds, when fairly on the wing, travel at a great pace, shooting along like feathered meteors, over the water and under it. They are as much at home there, for 
the time being, as the fish they feed on ; if alarmed in any way, they sink the body, so that only the head and part of the neck are above water-a very small mark to cover from a boat. Should the shot take effect, well and good; if it does not, it is not the least use rowing after the specimen, or, for the matter of that, sailing. The fishing-nets sometimes mesh these fowl when they are racing the shoals, but not so often as they do the Great Northern and the Red-throated Divers.

The Black-throated species prefers fresh waters as a rule. On the hill lochs in summer they are fairly numerous at times, several birds being seen together. They are eagerly sought for as specimens for setting up, but like its larger relative, this is a wary bird. A pair of Black-throats in full feather are no small prize for a shooter, for their haunts are not very accessible ones, and the birds are far worse to get at. But in point of fact they must be considered merely as visitors, for the few that breed in Scotland and the Isles are as nothing to those that visit us from northern lands. Selby, in ${ }_{1} \$_{34}$, discovered this species nesting at the foot of Loch Shin, and upon most of the interior Sutherland lochs. The nest, if a bit of bare ground at times can be called one, is a short distance only from the water, so that the bird, sitting horizontally on her eggs, not upright, can push herself off them, and glide on the cushion feathers of her breast into the water like a seal. The long, oval-shaped eggs, two in number-sometimes three-are brownish-olive, 
sprinkled all over with black and dark brown, with larger spots of the same colour at the broader end.

The Red-throated Diver is the smallest and commonest of its kind. It is a regular visitor on all our coasts during the winter. For nesting purposes the bird goes to more lonely spots than does the Black-throated species, and it selects rather the edges of small moorland tarns, than islands on lakes. The eggs are laid so close to the water that they are often quite damp underneath. The male helps the female in hatching them out. "Kark-karkkarkera!" cries this diver, and it is said that these notes are uttered mostly before wet or stormy weather; hence the local name of Rain Goose.

The divers are a most interesting class of birds, and but little known to the general public. Their legs and webbed feet, as well as that marvellous arrangement of structure which appears, on dissection, for driving them through the water when they dive, I shall not be able to treat of here. I have examined these for hours, and then have left off, wondering still.

Sprat Divers, or Sprat Loons, have been familiar to me ever since I was big enough to come staggrering home under the light weight of a score of flounders in a small hand-net over my shoulders. Directly I could toddle I dabbled in and by the ticle.

A north-caster is blowing, bringing with it a sprinkling of snow-a regular biter it is; it hits you like peas from a boy's pea-shooter, for it is frozen 
snow. The news has reached me from men who were once my boyhood's school-mates to come to the tide. Five miles one must go on a lonely road, and after that, having crossed in the ferry-boat, seven miles of bad marsh tramping brings us to open water, a wide, wind-swept estuary. How we got there I do not care to say, but we had to clear a lot of dylies of considerable width, such as I would not attempt to leap now unless a bull was behind me.

But what a scene awaited us! There were about a score of small fishing-smacks working on the tide, some for one thing, some for another; sprats, young herrings, smelts, whitebait, and flounders, were all there, in exhaustless quantities.

The large Crested Grebe, known as the Cargoose, or Marsh Goose, Gaunt, Tippet Grebe, and Crested Ducker, is not now so numerous as it was in my young days. Drainage has had much to do with this, but not everything. Since the foolish craze for specimens of British-killed birds with their eggs and nests has come to the front, these birds have suffered with others. The old birds, their eggs and nests, also their curiously-striped young, all being brought in for collectors, measures have been taken at last for their preservation far more efficient than those that the Bird Act can enforce, and these are systematic personal supervisions by genuine sportsmen naturalists, on whose waters and meres a few pairs still breed. In winter this Grebe visits the coast; in fact, if the weather is very severe, all 
those we shall notice are found on the tide, as a rule not far from shore, but there are exceptions even to this. Birds of the year, and immature birds, are more frequently met with than adults; this is the case, as a rule, with all diving fowl. As a diver, this bird is in the front rank; you will see him gliding under and coming up again in the most quiet manner.

Before us is a long, shallow lagoon, deeper far in mud than water, although in the centre the water may be from five to six feet in depth in some parts. One hundred yards it may be at its widest, and there is a patch of reeds across it. The tide slowly forces its way to this, just enough to make the dead drainings from the uplands brackish; for only a small run from a tall dyke enters this long, creeping bit of water, that runs for five miles right through some of the marshes. The reeds are very thick here, and a rare height. There is not much to be scen in or on such bits, as a rule, for the show is inside in the reed channels. A pair, if not a couple of pairs, Duckers by name and duckers by nature, frequent this bit, but it is difficult to get a look at them. We do see one, but only for a few seconds, as he rises with a fish a little too large for him; his tufts and ruff are bluffed out in the efforts to swallow it, making him look as one just a little bit wild about the head. 


\section{THE GREAT NORTHERN DIVER.}

\section{(Colymbus slacialis.)}

MaLE.--The bill is black, three inches in length, the tips being horn-coloured. The iris is bright red. Head and neck are a deep bluish-green, glossed with purple. There is a patch on the throat, and a broad ring on the neck, not completed in front, of white streaked with black. The upper parts of the birds are black. The middle of the back and scapulars have rectangular white spots. The wings have the white spots round, two of them on cach feather. The tail is brownish-black; the primary coverts, primary and secondary quills are brownish-black, glossed with green. The sides of the lower part of the fore-neck are streaked, or "striated," with black; the edges of the bocly greenish-black, sprinkled with white dots. Lower parts glossy white; legs and toes bluish-purple externally, tinged with reddish-yellow internally. The membranes are blackish-brown, paler in the middle. The length, from bill to tail, is thirty-six inches.

Fenale-Resembles the male in plumage, but is smaller.

In the young the bill has the ridge of the upper mandible dusky; basal part and edges, with the whole of the lower mandible, greenishyellow; iris brown. The upper part of the head and nape are dark greenish-brown. The hind-part and sides of neck are grey brown, the latter marked 
with greyish-white; the upper parts blackishbrown, the feathers margined with ash grey. The tail and quills brownish-black, glossed with green; fore-part of neck greyish-white, faintly marked with grey, the cheeks also; lower sides of neck streaked with grey. Lower parts pure white, with the cxception of a grey-brown band across the hind-part of the belly. The feet dusky externally, buffish flesh colour internally; membranes flesh-coloured. Length, from bill to end of tail, thirty-one inches.

\section{THE BLACK-THROATED DIVER.}

(Colymbus arciticus.)

MALE. - The bill is black, two inches and a half in length; iris red. The upper part of the head and the hind-neck are light grey; fore-part and sides of head darker; fore-neck purplish-black, ending below angtilarly, having a band of interrupted white above; the sides and lower part of the neck in front are dusky, streaked with white. The upper parts are black, glossed with green in front, shaded with brown behind. There are two dorsal bands of square white spots; the scapulars have larger spots of white. The lower parts of the body are white, with a lengthened band of dusky on the sides. The legs and feet are grey blue externally and light nesh-coloured internally; the membranes or webs are flesh-coloured. Length, from bill to end of tail, twenty-eight inches.

Fisule.-Similar to the male but smaller, the length from bill to ail being twenty-five inches. 
In the young the bill is light grey blue, dusky along the ridge, and whitish at the base of the lower mandible; iris brown. The upper part of the head and the hind-neck are a dark greyishbrown; the cheeks greyish-white, finely streaked with dusky; fore-part of the neck greyish-white, faintly dotted, its sides below streaked with brown. The upper parts of the body are brownish-black, the feathers having broad light grey margins. The hind-part of the back is a dull brownish-grey, the tail feathers are dusky, margined with grey. The quills are brownish-black, the secondaries being a lighter tint, margined with grey. The lower parts of the body are pure white; the feathers on the sides and some of the lower tail coverts are dusky, edged with bluish-grey. The legs and feet are a dusky grey, paler on the inner side.

\section{THE RED-THROATED DIVER.}

\section{(Colymluss septentrionalis.)}

NALE.-The bill is bluish-black, two inches and a half in length; iris bright red. The sides of head, neck, and throat are bluish-grey, the upper part of the head being marked with small dark spots. The nape, hind-neck, and lower parts of it are streaked with black and white. On the forepart of the neck is a lengthened broad band of orange red. The upper parts are brownish-black, glossed with green, without any white spots. The lower parts are a glossy white; the sides greyish- 
black. A narrow band of dull grey runs across the hind-part of the belly. The legs and feet are brownish-black externally, and pale bluish fleshcoloured internally; the webs, or membranes, are flesh-coloured. Length, from bill to end of tail, twenty-six inches.

Fenale.-Similar to male, but smaller. Length, from bill to end of tail, twenty-three inches.

The young in winter. - The bill is flesh-coloured at the base, and bluish-grey towards the end; iris brown. The upper part of the head and the hind-neck are greenish-grey, finely streaked with a paler tint, the latter showing more on the neck. The checks and sides of neck are white, with faint grcy markings; the fore-part of the neck white, faintly marked with small grey specks. All the upper parts are a deep glossy greenish-grey, fincly speckled with greyishwhite. The primary quills blackish-grey, tinged with green; the secondaries are like the feathers of the back. The tail feathers are tipped with greyish-white; the lower parts pure white. A faint grey band runs across the hind-part of the belly. The legs and feet are clusky externally; internally, including the ridge of the tarsus, they are light bluish-grey; the webs, or membranes, dusky at the sides, dull flesh-coloured in the middle. Length, from bill to tail, twenty-five inches.

The measurements given are general ones. The divers which I have recently received from the tidce, directly they were shot, have in all three species slightly excceded the measurements I have 

given. The adults are described in their summer plumage (nesting plumage), the young in their first winter plumage. To give the intermediate changes would take up too much space in a work of this kind.

\section{THE GREAT CRESTED GREBE.}

\section{(Podicipes cristalus.)}

MaLE. - The bill is two inches in length and carmine-coloured, the ridge dusky, the tips yellowishgrey; iris carmine. A bare dull green space runs from the eye to the mouth. The upper part of the head and occipital tufts are greyish-black with a tinge of green; the ruff reddish-brown in front, and greyish-black behind. From the upper mandible over the eye is a band of reddish-white; a part of the throat and cheeks is white below the ruff; the fore-part of the neck is white, with a tinge of brown on the sides. The hind-parts are blackish-grey. The upper parts are greyish-black, with a brown tinge. In the front edge of the wing all the humeral feathers, and nearly all the secondary quills, are white; the lower parts of the body silvery white. The legs are dusky green externally, greenishyellow internally; the toes are greenish-yellow above and dusky below, also dusky towards the margins. The length, from bill to end of tail, is twenty-three inches.

Female.-Smaller, and has the occipital tufts and ruff shorter, but similar in other respects. Length, from bill to end of tail, nineteen inches. 
THE RED-NECKED GREBE.

(Podicifes sriseigena.)

MALE.-The bill is black, paler at the end, light yellow at the base. The iris is carmine; the upper part of head greyish-black; cheeks and throat ash grey. The ruff is edged above with white; the fore-part and sides of neck being a rich brownishred. The upper parts are greyish-black, with the edges of the feathers lighter; the front edge of the wings is narrowly marked with white; the outer secondaries are white; the lower parts silvery white, with dusky streaks on the sides. The feet are greenish-black externally, with the lobe margins dusky. Length, from bill to tail, cighteen inches.

Fexiale-Similar to male, but smaller.

In any state of plumage, young or intermediate, this species may be distinguished from the Crested Grebe by the bill being thicker, and the base yellow instead of carmine.

\section{TIIE IIORNED GREIBE.}

(Podicipes anvitus.)

MaLE-The bill is bluish-black, with the tips yellow. The iris is carmine, with an inner ring of white. The upper part of head, ruff, cheeks, and throat are glossy black. A band from the biil, over the eyce, including the occipital tuft, is yellow ish-red. The fore-part of neck and sides of body are brownishred, and the upper parts ereyish-black; the feathers edged with dull grey; secondary quills white, and 
some of the feathers on the humeral quills greyishblack. The length, from bill to end of tail, is fourteen inches.

Female.-Similar to male but smaller, with tufts and ruff shorter, and not so bright as in the male. The feet are dusky, tinged with grey externally, dull yellow internally.

YounG: Winter.-The upper part of head, hindneck, and upper parts of the body are greyish-black, the edges of the feathers lighter. The throat and cheeks are white; fore-neck pale grey; lower parts silvery white, with dusky markings on the sides.

\section{THE EARED GREBE.}

(Podicipes nigricollis.)

MALE. - The bill is black, with a tinge of blue. The iris carmine, with two small dusky tufts, a short black ruff, and a long tuft of orange red feathers from behind each eye. The upper parts are greyish-black; the lower silvery white; sides light red, streaked with black. The feet are greyishblack externally, grey green internally. The length, from bill to end of tail, is thirteen inches.

YounG : Winter.-The upper part of head blackish-brown, darker behind, shading into greyish, reaching below the eyes, and covering part of the cheeks; fore-part of neck greyish-brown; upper parts of body brownish-black. The wings are of a browner shade, with white markings, as in the adult. Lower parts silvery white. 


\section{CHAPTER XXIV \\ CORMORANTS AND GANNET}

Tine Common Cormorant is called Coal Goose, Great Scart, Scarve, White-headed Cormorant ; this latter name applies to the full breeding state, when the fine white lines on the head and neck show for a brief time very conspicuously. Crested Cormorant, Great Cormorant, and White-spot Cormorant are the names it is known by on the coast-line.

This fisher is, to a certain extent, local as to choice of habitat; fish in large quantities it must have, for it is a voracious feeder, yet in proportion to its size not more so than other fish-eating birds. Of the Cormorant it may well be said that good digestion waits on appetite.

The young birds wander about considerably at times. As a rule, all the bircls of this species that we have seen procured inland, from rivers, lakes, meres, and from trout streams, have been more or less in immature plumage. Adults have, at various times and places, been found perching in or on most extraordinary perches for a sea-fow. Church towers and their weather-vanes are frequently ornamented 303 
by this web-footed percher. Scarts are well known, and their diving powers are proverbial.

The Cormorant uses its wings as well as its large paddles when diving. Grebes do not use their wings, for the hind-parts are finished off seal fashion, taking into consideration that they are birds, and they use their leaf-like, fringed feet to send them through the water when they dive, much in the same manner as seals do.

Sea water is very clear at times; there is some quality in it that permits you to see down for far greater depths than you could in spring water. The movements of all divers under water are executed with extreme rapidity. I have seen a little of their movements under water; not one fraction of what I should have liked to see, but one must rest contented. No greyhound-and I have seen some of the best in my time--ever coursed hares with greater keenness than these submarine feathered divers use in coursing the fish.

I will try to give my readers some idea of what this fish-coursing is like, as I have seen it, fragments at a time. There is a sprat-boat on the tide, waiting to work her nets. She is the first one of the small fleet that has made her appearance there for the season, and she, for the time, has anchored. So far as the water is concerned, it might be the calmest of summer weather ; it is "Gin," or, rather, "Hollands clear"; quite clear enough on the sandy parts, close inshore, for flounder-spearing. But we are some distance from shore; three miles out, at 
least, from the marsh-lands. The weather is cold enough to make us "beat the booty," as they term it; that is, thrash your ribs with your open hands vigorously. Lip-lip-lip-lip-lip-lip, lipper-lipper-liplip-lip-lip-lip, like the rain falling on the surface; yet it certainly does not rain. The sound is caused by countless catches of sprats swimming close to the surface, feeding as they swim; the "sprat rain," so called from the noise the shoals make. Tre can see the surface ruffled by their progress, and they are still coming, from where our boat is anchored. "Shin up an' look down on 'em," our friend shouts from below. This we quickly do. Cackle and bark! bark and cackle! This comes from a couple of Cobs. Down one drops, snatches a fish (a young herring by the look of it, for it is three times larger than a sprat), and his mate fights him for it, before he can pouch it. They are thrashing each other with their strong pinions viciously, digging with their vulture-like bills, making the water flirt up in all directions. There is enough fish around and beneath them to have them off the surface of the water; but no, they must fight and squabble in the midst of tceming abundance, because it is their nature so to do.

This is not peculiar to Gulls, for other creatures besides birds squabble at times over a good find, or quarry. The divers have not flown with the shoals, but they have swam with them. Some are at work below us; we see grey streaks and white flashes as the birds dash round the boat. Their speed is so 
great that a flash is all you can call it. After a bit one head pops up, then another; only for a second or two for breath, and then at it they go again. Then a large birct rises like a seal from the water, and plunges again. Quick as he is, we know that is a Cormorant, or Scart. If I may be allowed to compare marine matters with those of the land, the way that the divers rush about round the shoals is very like that of sheep-dogs gathering a large flock of sheep into a small compass.

Loons, Cormorants, Guillemots, Razor-bills, and others have all been kept in ponds constructed for the purpose of observing their movements under water, when in pursuit of their finned prey. As I have observed before, birds adapt themselves to circumstances, and the Cormorant would soon find out that he would cripple his wings if he used them in those comparatively shallow pond structures. So he throws his large webbed paddles behind him, and shoots along seal fashion. The fish must be fresh -that is a vital necessity; but dead haddocks, whitings, herrings, and others, do not require much exertion to procure when they are thrown in to them.

Diving birds, in a captive state, soon get like trout, pile, and perch under similar conditions, artful. They know exactly what they have to do to get their food, and they work accordingly for it.

The Cormorants, like otters, can be, and are, trained to catch fish for their owners. Some train both, others train the Cormorants alone for this 
purpose. The birds, not the otters, are captured in a wild state by a very simple process, and then are trained as Hawks or Falcons are trained for sport-the very cream of sport this is, for the fowl and fish themselves are as nothing in it.

Both Cormorants and otters can bite; the bite of the first may be forgotten and forgiven, for it is only the nip of a bircl, but ask any one that has been fixed by the otter how he liked it, and you will hear some strong language. There is no more trouble with trained Cormorants than with rabbit beagles-indeed the birds are more tractable. Sometimes, for a treat, the owners of the birds take their throat-straps off; and let them fish on their own account. When this takes place, their keepers or attendants have to carry them home, for, like "old Biddlecome's" proverbial seventeen-year-old gander that he fatted up for Christmas, they have managed to get a little more insicle of them than they can walk with nicely:

Much nonsense has been written about the Cormorant, as well as of other bircls. In fact, the Owl, the Cormorant, and the Bittern have all had the bad luck to be slandered. Yet the trio are irstrate and most amusing feathered companions; the first is, as he looks, wise in his own way ; the scound intelligent and useful; and as to the Bittern, he is a feathered contortionist.

If one lived for two hundred years one woukl never read the whole ridkle of Nature's childen.

About the Solin Goose, or Common Ginnet, 
much has been written, so we will say nothing about this long-billed fowl, except that on the eastern lines of coast, and elsewhere as well, it can at times be seen following the shoals, and plunging with others, both old and young, of its family-or, to be strictly correct, families - with the regularity of clockwork.

So much is the Gannet a wanderer, that, like the Albatross, in the breeding season excepted, it is continually on the wing. This bird plunges when flying, and not from the face of the water.

\section{THE COMMON CORMORANT.}

\section{(Phalacrocorax carbo.)}

MALE.-The bill dusky on the ridge, greyishbrown on the sides, the base yellowish-white, tips brown; iris bright; a bare space round it greenishbrown; bright yellow below; also yellow pouch or gular sac. A broad band of white crosses the throat from one eye to the other. The head, neck, lower parts, a band down the back, middle and hind-parts are black, glossed with bluishgreen. The feathers on the fore-part, and sides of back, scapulars, wing coverts, and secondary quills are greyish-brown edged with greenish-black, having green and bronze reflections. The primary quills and tail are greyish-black; a patch of white over each thigh according to season. The head and neck are finely streaked with white; the legs and feet greyish-black. Length, from bill to end of tail, thirty-eight inches. 
The female is similar to male, but smaller.

In the young, the bill is pale brown; iris brown; bare skin at base of bill flesh-coloured; upper parts greenish-brown; head and neck with paler streaks. The feathers of the fore-part, sides of the back, and wing coverts are brownish-grey, bordered with dark brown; quills and tail feathers brownish-black; fore-neck and lower parts of body grey brown, fading into white on the breast and belly. The changes from the first year's plumage clescribed above are, of course, varied.

\section{THE GREEN CORMIORANT.}

\section{(Phalacrocora. sraculus.)}

Male. - The bill is black; the base of the upper and lower margins of the basal part of the bill are yellow, streaked with black; a bare space round the eye, and from that to the bill, is black; iris green. The general colour of the plumage is greenish-black, and lustrous; the feathers on the back and wings lighter, and margined with velvet black. The primary quills and tail are greyish-black; the legs and feet black. In the breeding season this bird has a tuft on the head, two inches in length, of erect incurved feathers. Length, from bill to tail, twentynine inches.

The female is similar to the male.

Black Cormorant, Green Scout, Shag, Crested Cormorant, and Green Cormorant are the names this bird is known by, the last being the best one. 
3IO WILD-FOHL AND SEA-FOWL OF GREAT BRITAIN This, as a rule, is not so frequently met with as the common bird, except on certain parts of the coast.

\section{THE COMMON GANNET.}

(Sula bassana.)

Male.-The bill is pale blue grey; the lines on the upper mandible blue black. The bare spaces about the eyes and throat are the same colour; the iris is bluish-white. The head and hind-neck are pale reddish-buff; upper and lower plumage white. The primaries and first secondaries are a brownishblack; legs and feet dark brown, scutellated lines apple green. Length, from bill to end of tail, thirty-six inches.

The female is similar to the male.

The young are dusky grey, of a warm tone speckled with white; they are called, locally, Purple Geese. 


\section{CHAPTER XXV}

\section{THE GULL FAMILY}

That grand bird, the Great Black-backed Gull, Carrion Gull, or Cob, as he is more generally called, is one of the greatest feathered ornaments that our shores and waters can boast of at the present time; for the bird's cleanly-cut, well-contrasted plumage of black and white is as pure as the water that ripples over his dainty webbed feet. He is a bird for all weathers; sunshine or storm, winter or summer, make not the least difference to him, he beats up and clown the coast-lines and over the tide. As a rule they are pairs, sometimes single, except during the netting season. Then they come, like the marine vultures that they are, from wild, outof-the-way places known only to themselves. When that is over, for a time they beat back again to where they started from. A very wide-awake and cautious bird is the Cob.

The young Cobs, like other inexperienced creatures, come to grief for want of knowing how to take care of themselves at times; but not too often, for they inherit the instinct of self-preservation from 
their parents in a very remarkable degree. Traps account for some of them far more than the gun, both young and old ones. This at one time was not the case; at least I can answer for the fact that it was not so on those fore-shores known to myself. Bringing young Cobs, and if possible one or two adults - a more difficult matter-from far-off places, where the boats only had business once in the year at a certain time, was very different from their being interfered with on their own line of shores and fishing-grounds. The Raven has a very ancient look about him, as if he could tell a lot if he thought proper, but the Cob looks weird and uncanny, as if he was continually thinking over the creatures that he had seen go down to Davy's locker.

Here is a foreground of blocks and rough beach, strewn in places with heaps of washed-up deepwater tangle and bits of broken spars; the larger wreckage has been gathered. Flecks of dark dun clouds are drifting along in a clear blue-grey sky, that lights up a long stretch of sands which are glistening with wet, for the tide has only just gone down. Over the sands, backwards and forwards, beats a Cob. After a time he settles. There is no need this time to run and shout, to scare him off a wreck of poor humanity; he and his mate are devoting their utmost exertions to a dead marsh-land sheep. These dead creatures are, or at least they were, far too numerous at times than could be desired by any one. Hoodies, or Dun Crows, are there as well, and more are coming; but the reason 


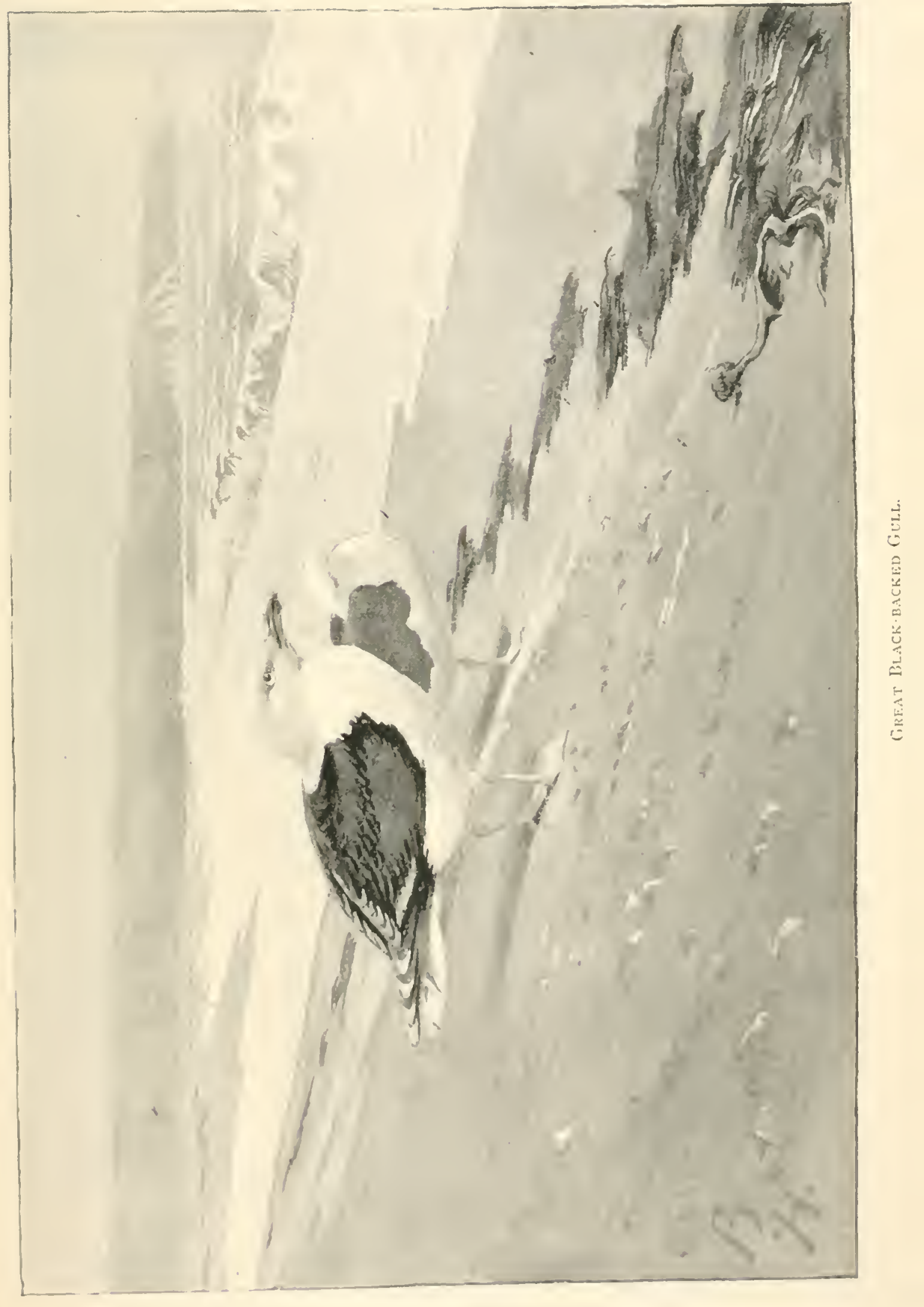



the adult birds were not shot at, nor any other means adopted for their capture or death, was that by their movements they told those that got their living from salt water what they might expect. No matter how fine the weather, or how fair the surroundings looked, if the Cob was scen on any parts of the flats above or below, those that saw him stand there, with one leg tucked up, and his head drawn in on his shoulders, told all within hail, as they made their passage, what they had seen. Thirty or forty miles is as nothing for the pinions of these strong birds. The tame Cobs, too, those that survived the chastisement given to them for using their bills on people without just cause, told the same tale in a different way; when foul weather was coming, they barked and cackled; not only that, they bit all that came near them a little more sharply than usual. One or two of the craft that I knew were what were called North Sea boats, built on lugger lines. If old Cobs had been seen in the position mentioned on any portion of the marsh flats, on either shore, the captains and owners of those vessels, as well as the crews, would be seen in a state of restless activity getting ready to make the open sea, if it blew a hurricane outside. Fully fitted with running gear, spare anchors, and spars these were, and not a man of course in the crews but what knew his place, and what to do in it.

This was a cause for wonder to me, and it had to stop at that, for questions I clared not ask when I was young. I had been told that it was a fault that 
carried heavy punishment with it. Why some of the elders of the community should tramp miles across the flats to see those vessels dash into open water, and give them a hearty parting cheer, I did not understand then.

Those vessels would dash round and about the sands, and other dangerous places, like the Cobs that had given them notice to go out, ready to help any ship in distress. Lights and lifeboats had not been developed in the magnificent manner they now have been. Salvage, of course, was one very powerful incentive, but that was not all; that came in afterwards-their hearts were in the right places, and beat all right. The crews of those luggers, and others as well, risked their lives to the very utmost to save both ship and crew, the crew first.

Hovelling, or hovering, names for wrecking a ship in distress, was not in fashion on the shores where I have watched and studied the Great Cob.

The Lesser Black-backed Gull, when in the company of its larger relative, is not to be distinguished from it at a distance. It is only when the boats are out fishing that the larger Gulls come near enough for their species to be made out with any precision. Old birds are mixed up with those of the first and second states of plumage. As we have not had them long enough in a captive state to note the time required for them to complete their full featherings, we must accept the opinions of old shore-shooters, that it takes at the least three years for Gulls to reach the perfect state of plumage. 
The young of the Lesser Black-back resemble in general colouring those of the larger bird. From their nests being repeatedly harried, some places where they once resorted to for breeding purposes have been deserted. As their large eggs are very good to eat, there is some excuse to be made; but at one time the last clutch or laying was always left for the birds to hatch out.

There is no reason to doubt what others have stated, namely, that this bird, at least, nested not one hundred miles from London. In a few more years such matters will become traditions of the past. With those that gain their living on the water large Gulls are not liked, for they do a lot of mischief. It is something very different, seeing a pair, or for the matter of that a couple of pairs, sedately flapping over the tide, or floating like corks on the water; then they are the ornaments of the fore-shores; but when hosts gather, Great Cobs, Lesser Cobs, and Herring Gulls, to wait on the boats and have their full share, clay after day, and week after week, the matter becomes serious. The fish are torn out of the nets, and the meshes cut and broken by their strong sharp bills.

It is a confused, shifting cloud of wings, black, brown, and grey-threshing, waving, and flapping; there are hoarse barks and cackles mixed with the querulous cries of the young birds. They are all there, the whole Gull family that frequent our shores, big and little.

Gulls are not considered as fowl, strictly speaking; 
yet they are eaten frequently by those that know how to deal with them. I have dined off a Herring Gull recently, and the Black-backed species are quite as good. The only thing to complain about is, that they have more feathers than meat on them. No one that had at any time of his life fowled on, or by, the tide would omit the Gulls, either in speaking about the fowls or in writing, for they hover about to prey on any dead or wounded bird. If a trap is set for one of the Raptores, the Gull gets in it; if a sheep that has died is poisoned for the benefit of the Hoodies, the Gull has his share and goes to sleep over it. But there is a bit of a drawback to this; those rough-coated, bob-tailed sheep-dogs are very sagacious, and think matters over on their own account. One of them I knew had seen his master make some dead mutton look very inviting, and as he was never kept on the chain, he sneaked off at night for a "blow-out." In the morning the shepherd found him dead on his door-flag. By the side of the doctored mutton he found one Crow. The dog had driven the Gulls away.

That fine, pure-looking bird, the Herring Gull, is larger than the Lesser Cob, and more stoutly built. In its general behaviour and habits it resembles those we have already noticed. All refuse is acceptable to this bird, whether washed up or brought down; no matter how, so long as there is enough of it. Marine vulture, as a comprehensive title, suits all three. That is one reason why they are so easily kept by the fishermen's children, for 
they will eat all that can be spared for them, and forage for themselves as well. Nothing hurts them but scrub-brooms and kicks, which luxuries are provided at times for them. When a bird of either species takes a piece of food from a child and cuts its fingers in doing so, it is very apt to get reprimanded; and if this takes place too often, the Gulls are apt to take a sad view of life and give matters up-pine away in fact.

Very few sea-birds give more pleasure to the wandering naturalist than does the Common Gull, that might, I think, be called the Lesser Silvery Gull, for it favours the larger Herring Gull very closely.

To a certain extent this bird, although called common, is local in its choice of habitat, for I have seen Black-backed Cobs and Herring Gulls in certain places in which I have not seen the so-called Common Gull.

Where large ploughed fields follow one another down the uplands, close to the tide, everything suits them admirably. It is a very pretty sight to see them following the plough for the small deer that they can pick up from fresh-turned furrows.

I have watched Rooks, Dun Crows, Hoodies, Jackdaws, Pewits, Starlings, and Gulls, the latter in greater numbers than the others, in two large fields, eighty acres in extent, close to the tide; and again within a couple of miles of it, on one upland farm, when I was a boy. I have seen them after they had filled their crops with mice that the plough 
had turned out of house and home, worms, grubs, and beetles, also cantankerous wire-worm, resting on the green turf of the marshes close to some shallow pools where they had washed their bills and feet.

If let alone this bird will throw off much of the extreme caution peculiar to this family. In fact, we have been able to get closer to them than we could to the Rooks.

They are harmless creatures, always on the lookout for unconsidered trifles. In the fishing season they gather with the others. When fields are manured with fish, then is the time to see them gather, if the heaps have not been scattered and ploughed in. Should the weather not be favourable to do this, two or three cartloads of fish soon go. But the good they do in and about the fields must be set against this.

Pickmire, Sea - Crow, Black - Cap, Mire-Crow, Laughing Gull, Black-headed Gull, Red-legged Gull, and Pewit Gull, are the names that the Brownhooded Gull is known by. Although this Gull is as a rule called the Black-headed, the title is not a right one; Brown-hooded, or headed, would be correct.

The local title, that of Pewit Gull, is very appropriate, for the bird is found frequenting meres and marshes. With the exception of that uncommon visitor, the Iceland Gull, these Gulls that I have lightly touched on will be found more or less in suitable localities by all those that fowl on or by the tide. 
The last bird that fell to the gun of the best of my old friends, when I shot with him in the marshes, was a Pewit Gull.

\section{THE GREAT BLACK-BACKED GULL.}

\section{(Larus marinus.)}

Male: Summer plumage.-The bill is pure yellow, with the patch near the end of the lower mandible carmine; iris pale yellow; the edges of the eyelids carmine. Head and neck are pure white; back and wings very dark slate colour, or greyish-black tinged with purple. The quills are tipped with white. All the lower parts are pure white; legs and feet flesh-coloured. Length, from bill to end of tail, twenty-nine and sometimes thirty inches.

Winter plumage. - The patch on the bill is orange red; head and neck white, with light brown streaks; rest of plumage as in summer.

The female is similar to male, but smaller. The sizes of these birds are a little different at times, also the depth of the clark parts of the plumage. The reason for this one need not expliain.

The young have bill brownish-black, base of lower mandible flesh-coloured; iris dark brown; head and neck hoary white, streaked with sreyish-brown, broader on the hind-part of the neck The upper parts are mottled with black, dirty white, and srey brown; wing coverts barrecl with brown; primary quills blackish-brown, tipped with white; tail feathers 
white, patched and barred with brownish-black and dusky. The lower parts are a mixture of greyishwhite and very light brown, barred and spotted with dark brown. The legs and feet are lividtoned flesh colour. The young are great speckled creatures of grave appearance in a state of captivity. Before they can use their wings, they make the very best use of their legs when alarmed, and hide up if possible. If you attempt to comfort them when they are querulously crying for the parents they have been taken from, they will bite you severely enough.

\section{THE LESSER BLACK-BACKED GULL.}

\section{(Larus fuscus.)}

MaLE: Summer plumage.-The bill is light orange; patch on lower mandible vermilion. Iris pale yellow; eyelids vermilion; head, neck, and all the lower parts snowy white. The fore-part and middle of back, scapulars, upper wing coverts, and secondary quills are a blackish-grey, with a tinge of purple; primaries and their coverts darker; all the quills tipped with white; legs and feet gamboge yellow. Length, from bill to end of tail, twenty-two inches.

Winter plumage.-The bill greenish-yellow; head and neck white, with light brown streaks. The rest of plumage as in summer.

The female is similar to the male, but smaller. With the exception of the dark parts of the plumage 
changing to a lighter tone as the bird ages, this species varies very slightly.

\section{THE HERRING GULL.}

(Larus argentatus.)

Male: Summer plumage.-The bill is pure yellow; patch on the lower mandible rich orange; iris pale yellow; edges of eyelids yellow. The head, neck, upper tail coverts, and tail are white. Back and wings light bluish-grey, some of the outer primaries greyish-black; all the quills tipped with white; lower parts white. Legs and feet fleshcoloured. Length, from bill to end of tail, twentythree inches.

The female is similar to the male.

In winter the head and neck are streaked with pale brown; the rest of plumage as in summer.

The young have the bill brownish-black; head and neck dirty white, streaked with grey brown; upper parts mottled with dull brown and brownishwhite; quills greyish-black; tail same colour, except at the base, where it is barred with white; legs and feet purplish flesh colour.

\section{THE ICELAND GULL.}

\section{(Larus lencopterus.)}

MaLe.-The bill yellow; patch on lower mandible orange red. Head and neck white, streaked with pale brown; rump and tail white. The back and 

wings light bluish-grey; quills all white at the end; lower parts white; legs and feet flesh-coloured. Length, from bill to end of tail, thirty inches.

Young.-The bill yellowish-grey at the base; brownish-black towards the end; ground-colour of plumage drab, streaked on the head and neck with brown. Upper parts irregularly barred; and the lower barred and mottled in a very confused manner with white and pale brown. Legs and feet fleshcoloured.

In hard weather this northern giant, the Burgomaster, occasionally visits us, but rarely in the adult state, more frequently in immature plumage. This and the White-winged Gull, or Lesser Iceland Gull (Lamus leucopterus) - a bircl very often mistaken for its larger relative-are the North Sea Gulls of the shooters.

\section{THE COMMON GULL.}

\section{(Larus canus.)}

Male.-In summer plumage the bill is greenishyellow; eyelids vermilion. Head and neck pure white; back and wings light bluish-grey. The quills in part black, largely tipped with white; lower parts pure white. In the winter the head and hind-neck are marked with brownish streaks and spots; the rest of the plumage as in summer. Legs and feet are decp greenish-grey. Length, from bill to end of tail, eighteen inches.

The female is similar to the male. 
Young. - The bill flesh-coloured at the base, brownish-black towards the end; eyclids dusky; head and neck dirty white, streaked with dull brown. Upper parts mottled with dull brown and brownishwhite; lower parts white, spotted with brown; quills brownish-black; tail white, with a bar of black at the end; legs and feet purplish fleshcoloured.

\section{THE BROIN-HIOODED GULL.}

\section{(Larus ridibundus.)}

MALE.-The bill and eyelids are carmine; iris brown. Head and throat deep brown, on the hindpart brownish-black. Back and wings light bluishgrey. Some of the quills are marked with black, the tips being whitc. Upper tail coverts and tail white; lower parts white; legs and feet carmine. Length, from bill to end of tail, sixteen inches.

The female is similar to the male.

In the winter the dark brown hood is lost; a few faint grey marks on the head, a blackish crescent before the eyce, and a patch behind it, only indicate where the hood has been. The other parts of the plumage, bill, and feet are as in the breceling plumage given above. 



\section{INDEX}

Altk, Little, 285, $28 \mathrm{~S}$

Avoct, 75 ; on Romney Marsh, 76 ; description of plumage, 93

Bitton, Common, I23; nest of, I23; local names, I 24 ; haunts of, I 26 ; on Essex side of the marshes, 128; description of plumage, I 30

Bittern, Little, 129

Bustard, Great, 1; some of its old haunts, 2, 3, 5; running down of, 3 ; food of, 5 ; description of plumage, 6

Bustart, Little, 5, 7

Coot, 154; good to cat, I55; description of, I 59

Cormorant, Common, 303; trained to catch fish for owners, 306, 308

Cormorant, Green, 309

Crake, Faillon's, 141, I 57

Crake, Corn, 143; local names, 143 ; birds bagged in Sussex, 145; description of, 158

Crake, Little, 142, $15 \mathrm{~S}$

Cratic, Sfotted, 141, I 57

Curlewi, 62-69; description of, yo

Curlew', Stone, or Thick-knee, 9-15

Divir, Black-throated, 291, 297

Direr, Grat Northern, 200, 296

Dizer, fied-throated, 293,298

Dotterel, Common, 20, 22, 23

Duck, Common Hill, or Mallard, $18_{3}$; half-bred, I8.; night-shooting, IS6-I8S; duck decoys, 189-196; labits of, I89, I90; an ohl coyman of the North lient marshes, I 96-199: feeding of, 202-204; a ballail from "fen and Mere," 205,206 ; plumage of, 206, 207
Duck, Eiter, 244; female Eiller shot on a Surrey moor, 246 ; plumage, etc., 25 I

Duck, Pintail, 220-225; description of, 227

Duck, Scaup, 274-280, 282

Dunlin, 46; shore-shooting, 49-54; plumage, etc., 59

Gadivall, 230, 247

Ginnet, 307, 30\$, 310

Garganey, see Tial

Godrint, Bar-tailed, 72, 9I

Godiut, Bluck-tailat, 73, 91

Goldin.ertic, 232, 247

Goosander, 252-254; plumage, etc., 258

Goose, Bern, "Wild gonse" of shoreshooters, I65, I 73

Goose, Burnacle, I66; "IIell-hounds," 167,174

Goose, brent, 167 : old shore shooters in quest of, 169-I72; plumage, etc., 174

Goose, Griylus, I64, 165, 173

Govos, I'ink-jooted, I66, I 73

Goose, Ithitiogrontid, I66, 174

Grete, Forew, 302

Gribe, Great C'vistid, 294, 295; de. scription of, 300

Grite, Horm.d, 301

Grebe, Rict-ntecheri, 301

crecrnshank, 7i; newing habits of, 7s; plumage of, 94

Grillimot, $2 S_{4}, 2 S_{7}, 2 \$ S$

Cinll, Sirman-howhit, 323

ciull, cimmon, 317,322

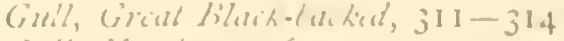

civli, Memins, 316,321

ciu!l, ficlani, 318, j21

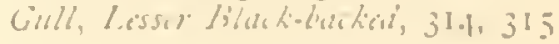


Havild, Long-tailed, 234, 248 Hcron. Common, I 7 ; heron-hawking, II $S$, I I 9, I 22

Heron, Nisht, 22, I22

Heron, Furple, 122

Inot, $43,5 S$

Lapiuing, Common, or Pezuit, 27; roolis feeding on eggs of, $2 S, 35$

Niallard, is $3,206,207$

Mersanser, Hooded, 256, 259

Merginser, Red-breasted, 254, 255, 259

Mo.rhen, I47; nest of, 149 ; plumage, etc., I 59

Oy'ster-catcher, or Sea-pic', 31, 37

Pervit, see Lafwing

Phalaroper, Grey', 73, 92

Phalaropi, Red-necked, 74; nest of, 75,92

Plover, Common, Ringed, 22-27, 34

Plover, Golden, is - 20, 32

Plocer, Grey, I6-1S, 32

Piover, Kentish, 35

Plozer, Little Ringed, 35

Pochurd, Red-huated, 270-274; great catch of, 273. 2SI

Pochart, Tuttect, 229, 246

Pruffin, 2S6, 289

Rail, Water, I34-I4I, I56

Razor-bill, Common, 2S6, $28 S$
Redshank, 79; a breeding haunt of, So, S2, 94

Ruff and Reeve, $38-42$

Sanderling, 4S, 56, 57, 60

Suntpiper, Common, 85-90, 96

Sundpiper, Curlew-billed, 47, 55, 60

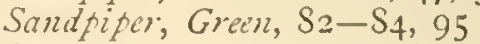

Sandpipir, Purple, 44-46, 59

Sindpeper, Wood, $\$_{5}, 96$

Scoter, Common, 235-242, 249

Scoter, Surf, 243, 250

Scoter, Velv't, 243, 244, 249

Shelit-duck, I $76-\mathrm{IS} 2$

Shoveller, 225, 228

Smciv, locally named Weasel-headed

Wigeon, 257, 260, 26 I

Snipe, Common, 107-I IO, I 4

Suipe, Great, 106, 107, I I4

Snipi, Jack-snipe, I I I - I I 5

Spoonbill, White, I 32, I 33

Stilt, Black-winged, 77,93

Stints, 46, 56

Stints, Littli, $5^{6}$

Siean, Bewiclis, I62, I63

Sican, Whooping, I6I-I63

Tial, 20S-212, 217

Teal, Gargancy, 2 I 2-21 7, 2IS

Tumstone, 30, $3^{6}$

Whimbrel, 69, 7 I

II'iseon, 262-270, 2SI

Hootiock, 98-106; two Woodcocks killed at one shot by Chantrey, I05 


31

$R^{\prime}$ 
103

- 103

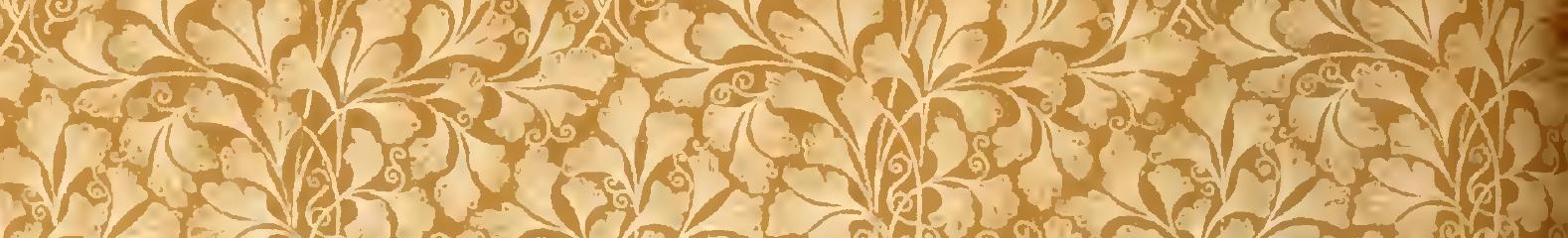
17 s.

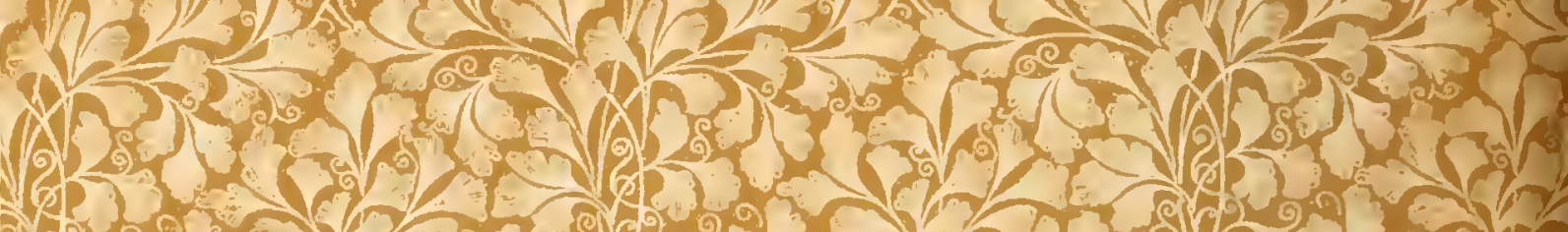

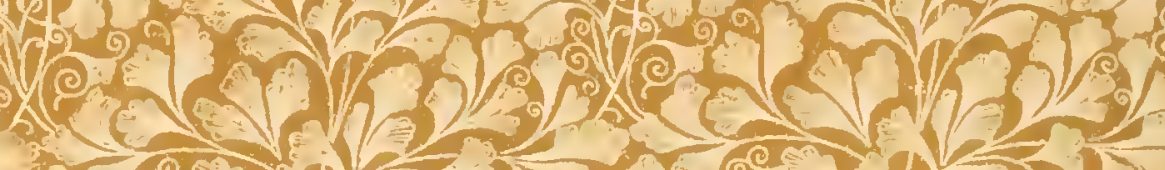

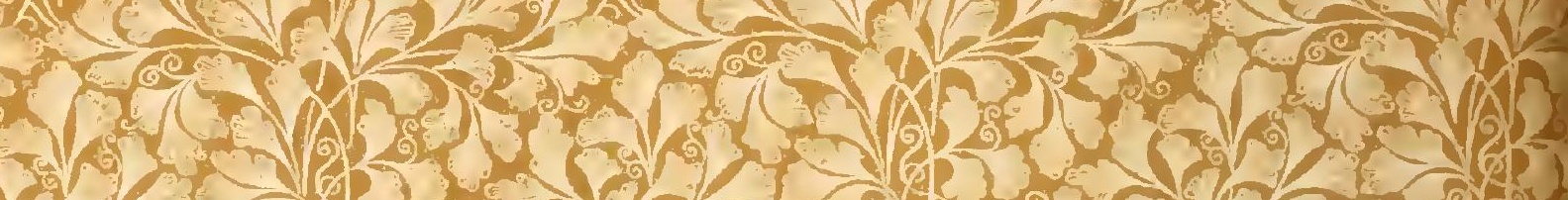

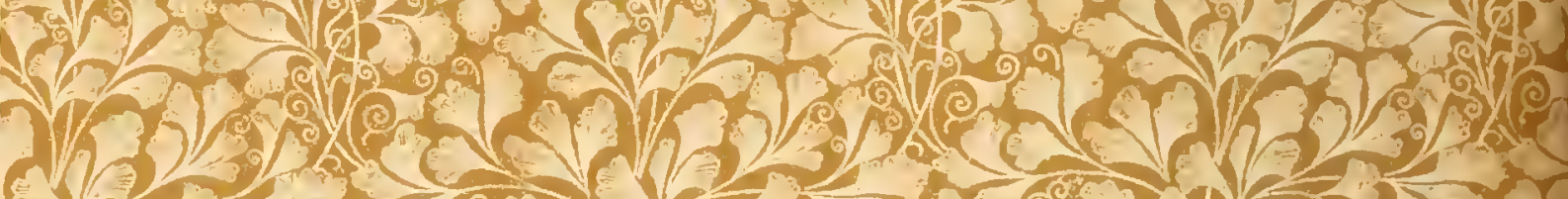

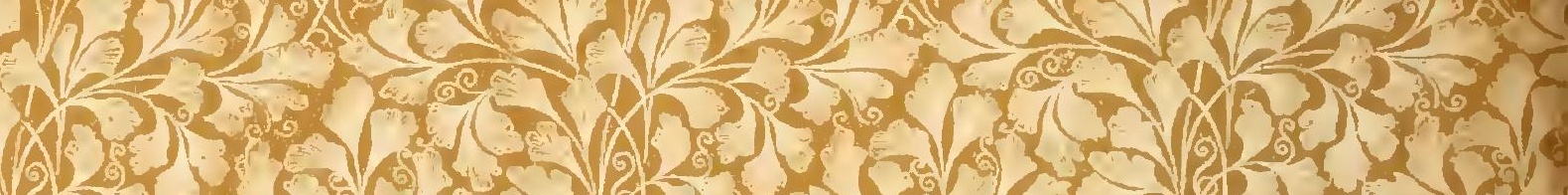

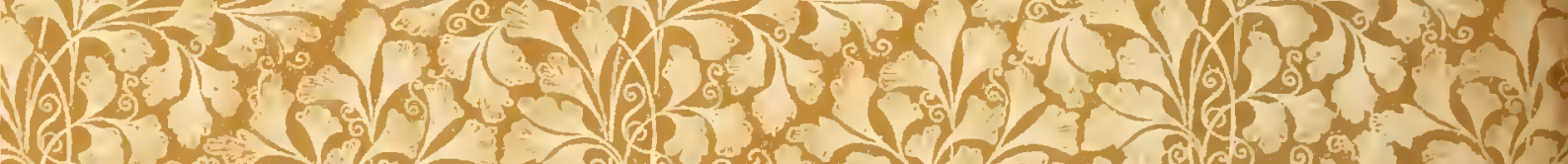
(c)

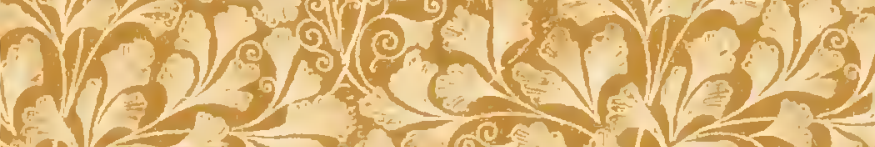

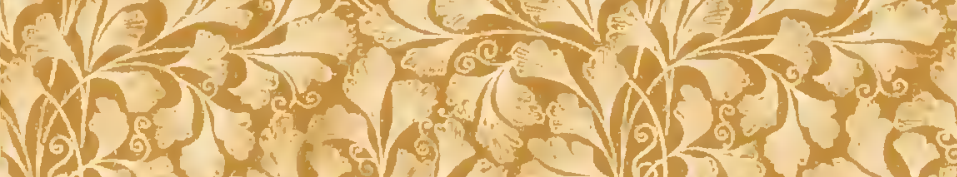

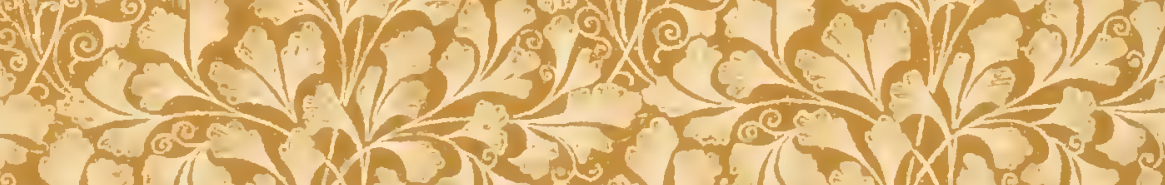

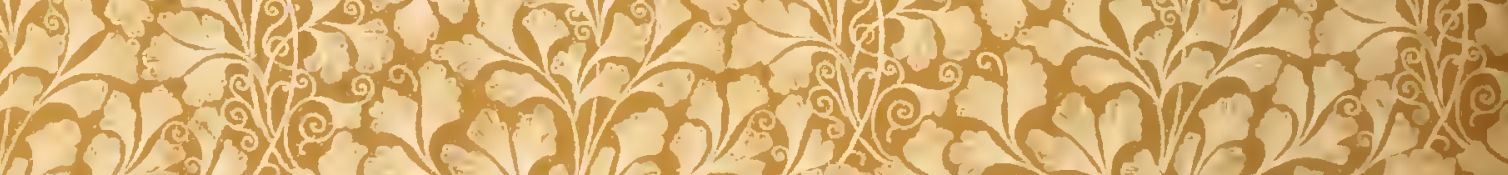

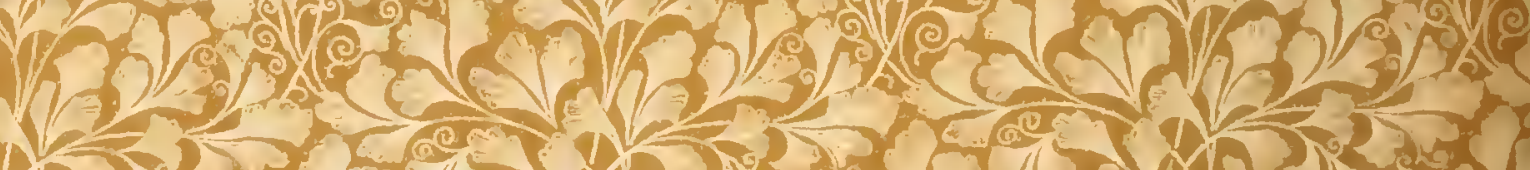

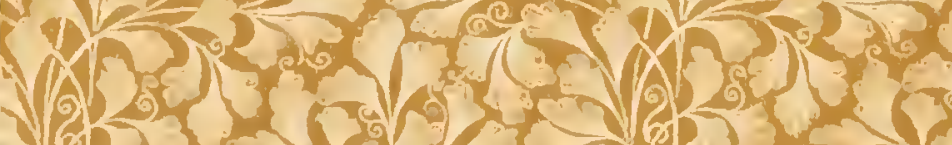



